DOI: $10.24275 /$ uama.5814.8258

\author{
Universidad \\ Autónoma \\ Metropolitana \\ Casa abierta al tiempo Azcapotzalco \\ DIVISIÓN DE CIENCIAS Y ARTES PARA EL DISEÑO \\ Especialización, Maestría y Doctorado en Diseño
}

\title{
PLAN MAESTRO URBANO PAISAJÍSTICO PARA EL HUMEDAL "LA SABANA", CHETUMAL, QUINTANA ROO
}

\section{Dante Ahuizotl Koh Romero}

Idónea Comunicación de Resultados para optar por el grado de Maestro en Diseño Posgrado en Diseño, Conservación y Planificación de Paisajes y Jardines

Miembros del Jurado:

M. en D. Armando Alonso Navarrete

Director de la ICR

Dra. Herlinda Silva Poot M.A.P. Félix Alfonso Martínez Sánchez Mtra. Karla María Hinojosa De la Garza Mtra. María del Rosario Dolores Mijangos

Ciudad de México

Agosto de 2021 


\section{DEDICATORIA}

Esta tesis es resultado del esfuerzo que como familia hemos logrado, con el apoyo mutuo de mi esposa Erika, el ejemplo de lucha y persistencia de nuestro hijo Dalí, el apoyo siempre presente de mi madre María de la Luz, y mis suegros Julia y Guillermo. Dedico esta tesis a todos ellos en reconocimiento a su bella y amable presencia en mi vida. 


\section{AGRADECIMIENTOS}

Agradezco el apoyo de mis maestros, M. en D. Armando Alonso Navarrete, Director de ICR; y mis asesores: Dra. Herlinda Silva Poot, M.A.P. Félix Alfonso Martínez Sánchez, Mtra. Karla María Hinojosa De la Garza y Mtra. María del Rosario Dolores Mijangos, quienes con su apoyo y guía me han acompañado en el desarrollo de la tesis. Agradezco a la Universidad Autónoma Metropolitana, Unidad Azcapotzalco por haberme dado tan cordial bienvenida y brindarme una casa más de estudios. Agradezco a la Academia Mexicana de Paisaje, al Colegio de Arquitectos Paisajistas de México, la Asociación Nacional de Parques y Recreación, así como la Universidad del Valle de Bolivia y la Universidad de Quintana Roo, quienes a través de sus Congresos me han permitido divulgar y compartir mis avances de Investigación, en particular al Laboratorio de Paisaje Ekohlógica, y a todos sus miembros.

¡A ustedes Maestros y Amigos, muchas Gracias! 


\section{RESUMEN}

"La Sabana" es un humedal de tipo palustre cuyo nombre permanece en la memoria de la gente de Chetumal; es un paisaje cultural que va desde lo degradado hasta lo extraordinario, en él se contrastan imágenes de asentamientos irregulares sobre el fondo de un cuerpo de agua extenso rematado por la selva mediana en sus diversas tonalidades de verde. "La Sabana" se extiende desde los evidentes cuerpos de agua que colindan con la ciudad, pasando por una zona de escurrimientos superficiales donde se aprecia un suelo gleysol y vegetación de tipo tular hasta desembocar en la Bahía de Chetumal. El crecimiento de la ciudad de Chetumal ha manifestado su impacto sobre este humedal a través de asentamientos irregulares sin servicios de drenaje sanitario que vierten sus aguas directamente a "La Sabana" o a través de fosos comunes; así mismo se construyeron caminos de terracería que atravesaron el humedal por muchos años impidiendo su funcionamiento natural y su drenaje, hasta que en 2015 se presentó una inundación por la precipitación pluvial y se tuvieron que abrir los caminos de terracería con maquinaria pesada, para permitir el drenaje natural que provee el humedal, lo que no fue bien recibido por la gente. En derredor de "La Sabana" se aprecian bancos de extracción de material pétreo y la presión urbana es cada vez más acuciante.

El "Plan Maestro Urbano Paisajístico para el humedal La Sabana" representa una oportunidad para integrar el humedal con la ciudad considerando la conectividad, la movilidad, la integración social, la recuperación de espacios de esparcimiento y equipamientos urbanos educativos y culturales en un sistema de áreas verdes urbanas conectadas por corredores urbanos y biológicos, potenciando el valor de "La Sabana" como un punto de encuentro y referencia para la ciudadanía.

Ello supone como primer problema la definición del polígono específico del humedal, lo que conllevó a estudiarlo desde la escala de la ecología del paisaje o escala regional, y posteriormente a escala urbana paisajística, para conocer la relación con la ciudad. En el primer caso se comprendió que la extensión del humedal sobrepasaba los límites 
urbanos, extendiendo su escurrimiento superficial hasta desembocar en la Bahía de Chetumal, mientras que en el segundo caso se analizó la estructura urbana, condiciones sociodemográficas, asentamientos irregulares entre otras cualidades urbanas para identificar problemáticas y potencialidades sobre el tema de estudio.

Las principales aportaciones van en función de reconocer el humedal como un sistema complejo que debe estudiarse a diferentes escalas y que así mismo tendrá una propuesta específica a esas mismas escalas, proponiendo que la zona de escorrentía se incorpore bajo un esquema de protección como parte del Área Natural Protegida Estatal del Santuario del Manatí, del que forma parte la Bahía de Chetumal; mientras que en el área urbana se le dé un tratamiento más específico, pero en todo caso tomando como referencia la Ley y el Reglamento de la Ley General del Equilibrio Ecológico y Protección al Ambiente referente a la zonificación para al establecimiento y manejo de las áreas naturales protegidas, lo que resultó una herramienta para acercarnos a la solución del problema como zonificación primaria, que permitió establecer espacialmente las políticas de protección o de uso de las diferentes subdivisiones del humedal.

Es importante reconocer el uso de los Sistemas de Información Geográfica para el análisis de las diversas capas de información que conjugan el territorio.

El Plan Maestro Urbano Paisajístico, es una respuesta lógica que interpreta espacialmente las variables urbanas, paisajísticas y medioambientales del humedal "La Sabana", y constituye un valioso ejercicio de trabajo de Planificación y Diseño en la búsqueda de la Salvaguarda y puesta en valor de un paisaje de carácter natural y cultural. 



\section{ÍNDICE GENERAL}

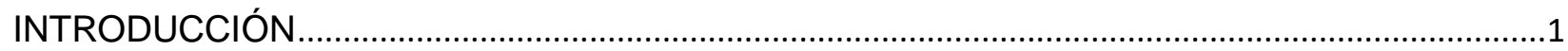

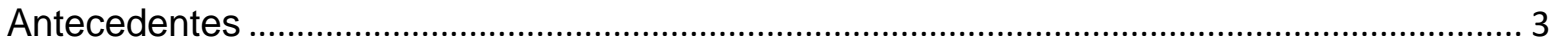

Planteamiento y delimitación del problema.............................................................................. 7

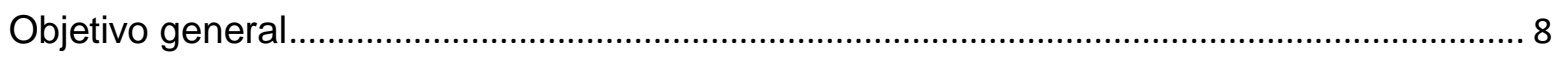

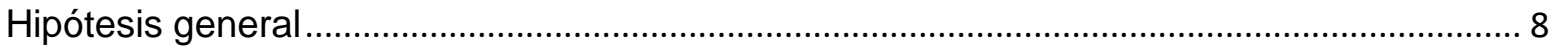

Motivación para elaborar la investigación ............................................................................. 8

Procedimiento y Metodología ………………………………………………………..... 9

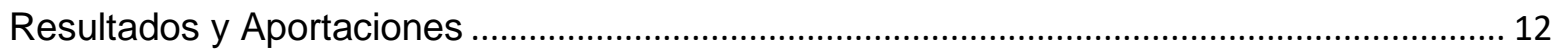

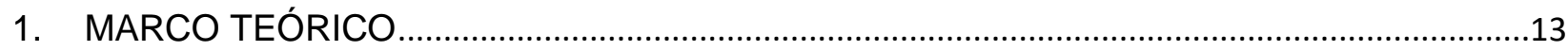

La Escuela de Chicago y las nociones de Ecología Urbana, y la Ciudad Jardín.....................13

El nuevo urbanismo y la sustentabilidad ..................................................................................17

1.1 Estado del arte ........................................................................................................ 18

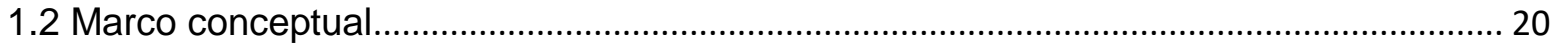

1.2.2 La concepción contemporánea del paisaje natural y paisaje cultural .......................20

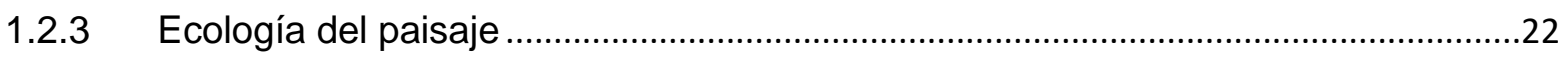

1.2.4 Urbanismo, sistema de espacios abiertos y áreas verdes urbanas .................................25

1.2.5 Humedales y la Convención Relativa a los Humedales de Importancia

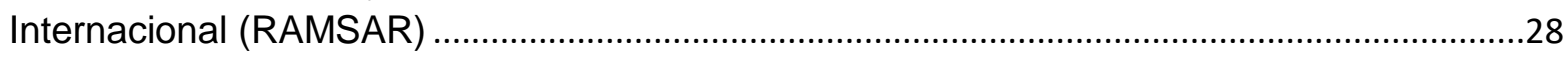

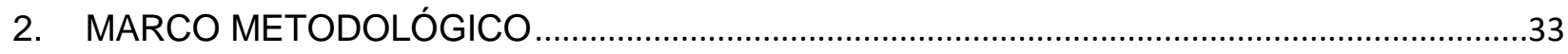

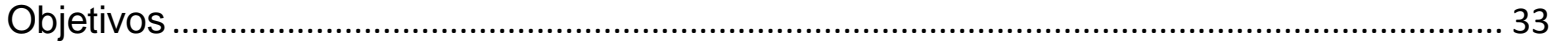

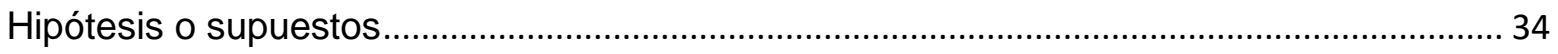

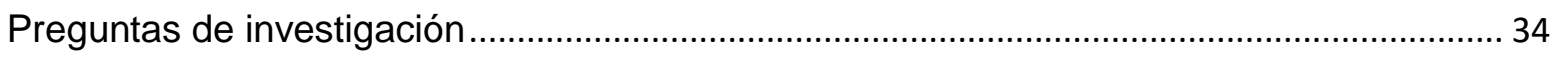

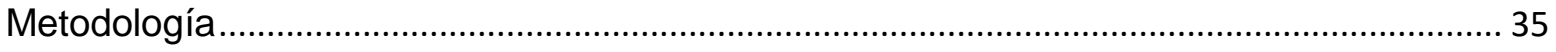

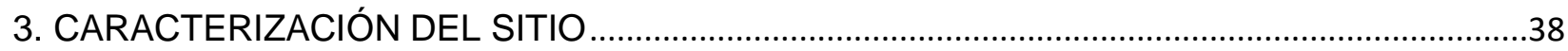

3.1 MARCO BIOGEOFÍSICO DEL HUMEDAL “LA SABANA" ................................................ 38

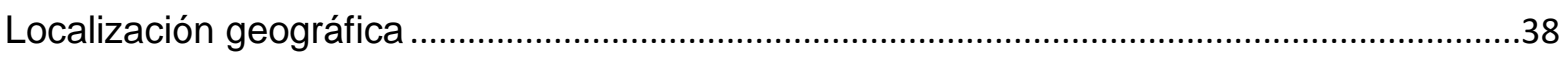

3.1.2 Región Hidrográfica ..................................................................................................

3.1.3 Corredores de paisaje asociados a cuerpos de agua y humedales................................43

3.1.4 Vegetación predominante ............................................................................................46 


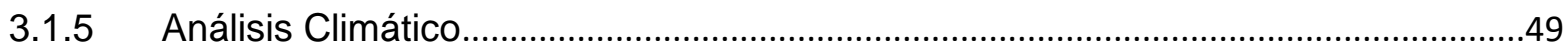

3.1.6 Áreas Naturales Protegidas y Humedales de importancia internacional .......................53

3.1.7 Delimitación del Humedal, límites funcionales, límites urbanos ...............................55

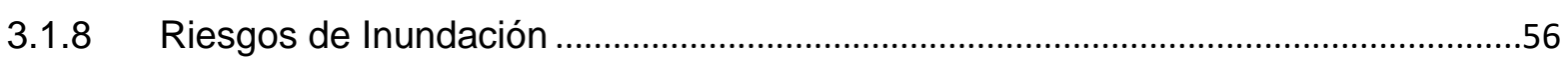

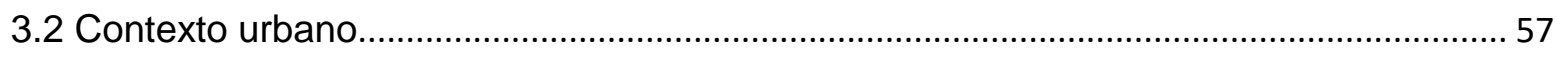

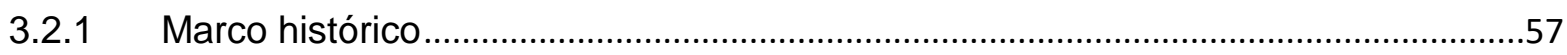

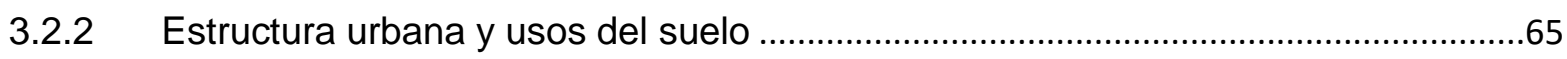

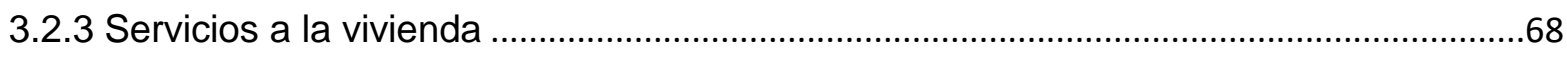

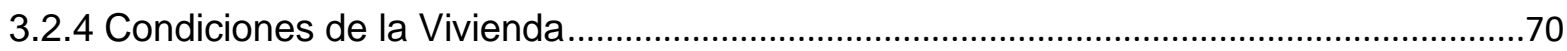

3.2.5 Equipamiento urbano zonal ....................................................................................72

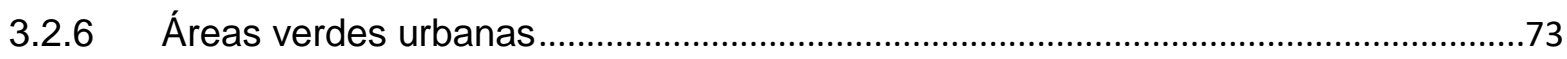

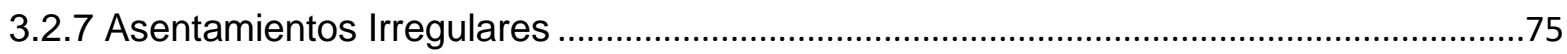

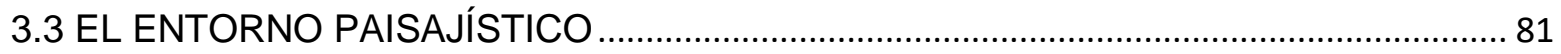

3.3.1 El Barrio como elemento identitario.............................................................................

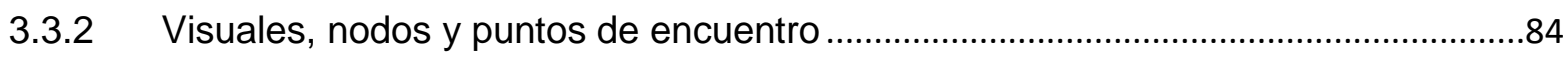

3.3.3 Percepción social del entorno y su relación con el humedal..............................................8

ENTORNO SOCIAL, CARACTERIZACIÓN SOCIODEMOGRÁFICA ……………................. 90

3.4.1 Grado de marginación urbana ...................................................................................90

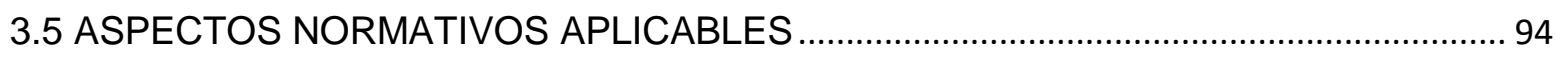

3.5.1 Programa de Ordenamiento Ecológico Territorial de la Región de Laguna Bacalar;

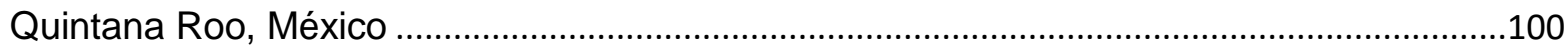

5.3.2 Programa de Desarrollo Urbano de Chetumal, Calderitas, Subteniente López, HuayPix y Xul-Ha. Municipio de Othón P. Blanco, 2018................................................................104

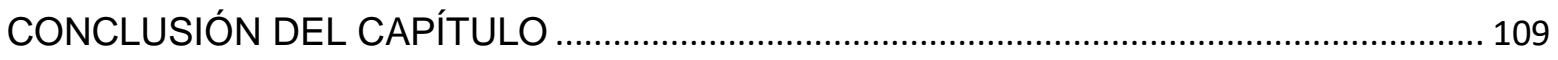

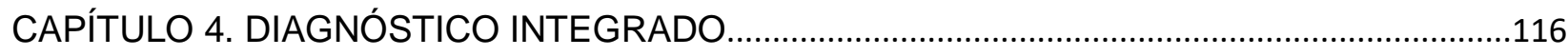

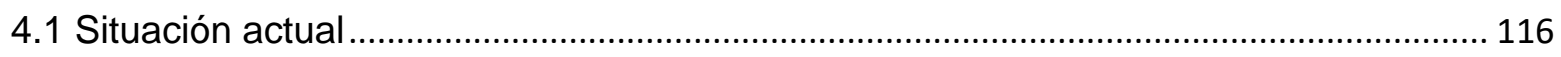

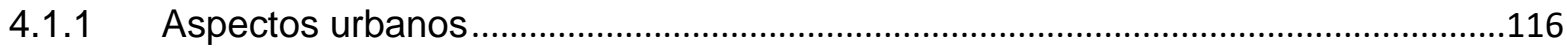

4.1.2 Aspectos Ambientales ..................................................................................118

4.1.3 Aspectos Sociales: relación con el humedal, percepción social y vulnerabilidad .119

4.1.4 Aspectos Paisajísticos ........................................................................................120

4.1.5 Amenazas, Riesgos Naturales y Cambio Climático ....................................................120 


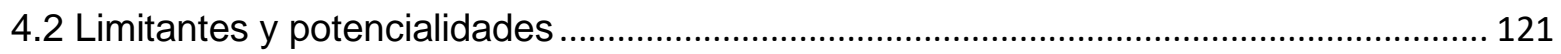

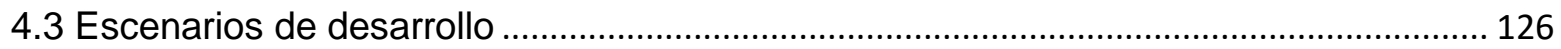

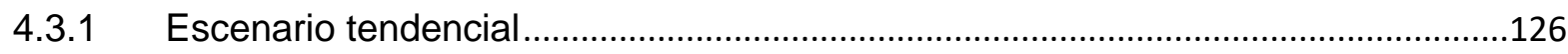

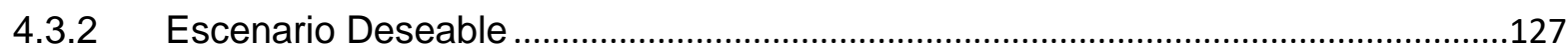

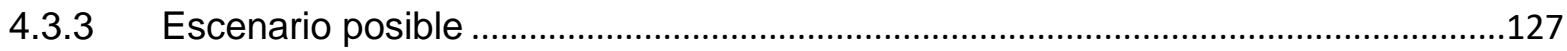

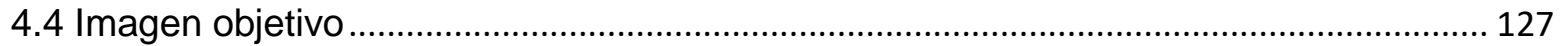

CAPÍTULO 5. LINEAMIENTOS AMBIENTALES, URBANOS, PAISAJÍSTICOS Y SOCIALES

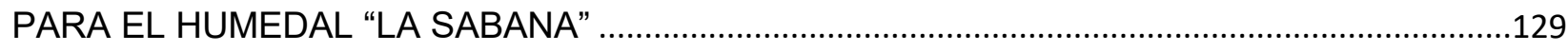

5.1 Objetivos ambientales, urbanos, paisajísticos y sociales............................................. 129

5.2 Lineamientos ambientales, urbanos, paisajísticos y sociales para el humedal "La Sabana"

5.3 Zonificación y subzonas del humedal “La Sabana”.................................................... 132

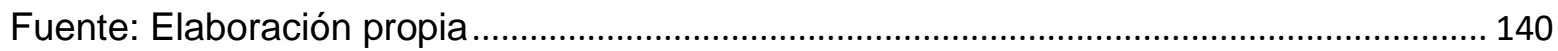

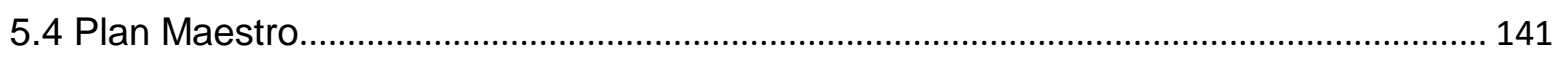

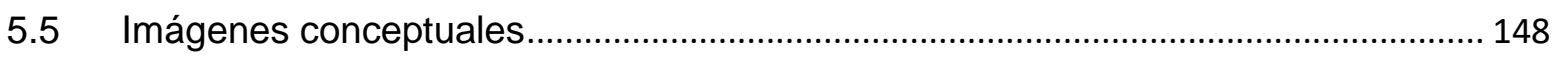

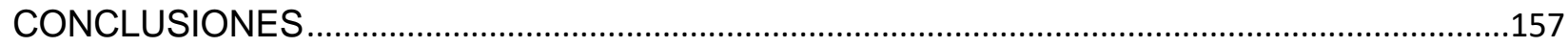

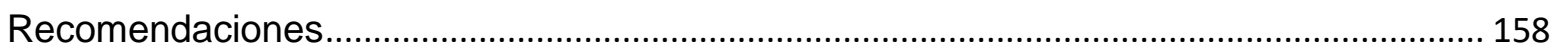

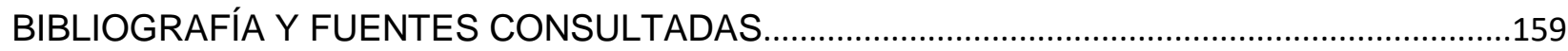

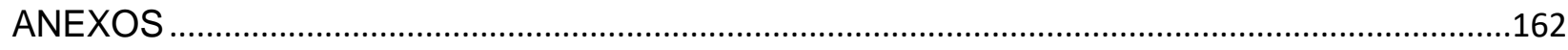

ANEXO 1. Encuesta de valoración de paisajes lacustres del sur de Quintana Roo............162

ANEXO 2. Listado florístico de especies nativas y cultivadas recomendadas para uso ornamental; y especies exóticas no recomendadas para uso ornamental. ..........................164

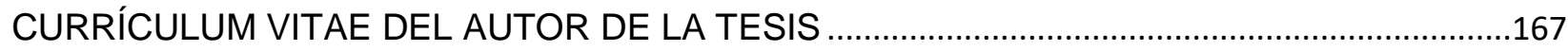




\section{Índice de Figuras}

Figura 1. Área de referencia del humedal "La Sabana"................................................................38

Figura 2. Zona de estudio, subcuenca hidrográfica RH33Ac, Bahía de Chetumal. ........................41

Figura 3. Zona de estudio, Ciudad de Chetumal, cuerpos de agua, humedales y flujos

superficiales de agua, Escala 1:200,000 .................................................................................42

Figura 4. Corredor de paisaje asociado a "La Sabana", escala 1:150,000 ……….......................45

Figura 5. Corredor de Paisaje "La Sabana", cuerpos de agua y zona urbana, escala 1:50,000..46

Figura 6. Temperatura mínima Chetumal, 1952-2012 ……………………..............................5

Figura 7.Temperatura máxima Chetumal, 1952-2012 ………………………………..............5

Figura 8. Promedio diario de lluvia y temperatura media, 1952-2012 ...........................................51

Figura 9. Promedios de lluvia históricos, Chetumal 1952-2012 ....................................................52

Figura 10. Áreas Naturales Protegidas " Santuario del Manatí" ........................................................54

Figura 11. Humedales de importancia Internacional, RAMSAR..................................................5

Figura 12. Área funcional del humedal "La Sabana" ...................................................................56

Figura 13. Zonificación primaria de la Ciudad de Chetumal, 2018. ...............................................57

Figura 14. Trazado de las primeras vialidades de Payo Obispo en 1902 ……………...................58

Figura 15. Traza Vial de Payo Obispo en 1922 .......................................................................59

Figura 16. Payo Obispo, faro y reloj público, antigua calle "2 de Abril" y antigua Av. "22 de Marzo" (hoy Av. Héroes y Av. Carmen Ochoa de Merino .............................................................6

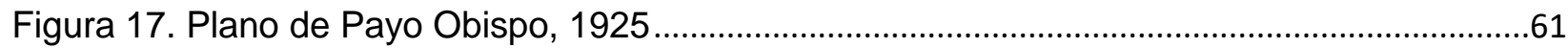

Figura 18. Ubicación de la colonia Venustiano Carranza. 1956 ......................................................62

Figura 19. Chetumal y su crecimiento poblacional en 1975 .........................................................63

Figura 20. Crecimiento urbano histórico de la Ciudad de Chetumal, 1898-1980 ...........................64

Figura 21. Etapas de crecimiento urbano Chetumal 1988-2014 ....................................................65

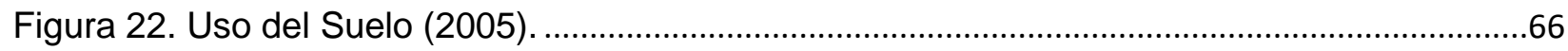

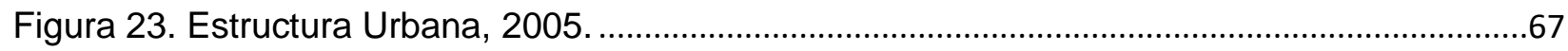

Figura 24. Caminos que atraviesan el humedal "La Sabana", 2017.............................................67

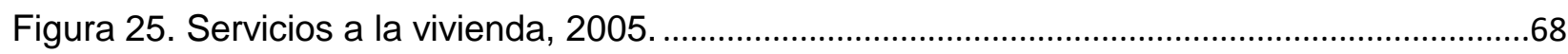

Figura 26. Red de infraestructura de drenaje sanitario (2018) ....................................................69

Figura 27. Plantas Municipales de Tratamiento de Aguas Residuales, referencia: Bicentenario.

Figura 28. Condición de hacinamiento y pisos de tierra en las viviendas, 2010............................70

Figura 29. Condición en la vivienda. Servicios Luz, Agua y Drenaje, 2010....................................71

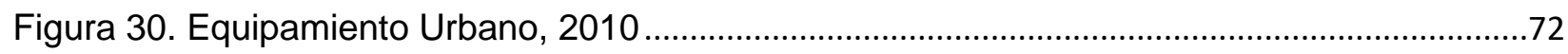

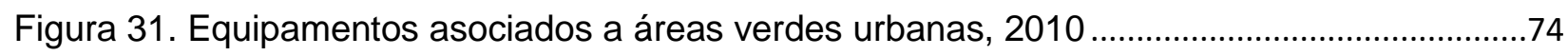

Figura 32. Mosaico fotográfico de asentamientos cercanos a "La Sabana".....................................77

Figura 33. Asentamiento irregular "La Virtud"...............................................................................78

Figura 34. Asentamiento Irregular "La Franja"............................................................................79

Figura 35. Asentamientos irregulares sobre camino que cruza el humedal ...................................80 
Figura 36. Asentamiento Irregular "Tamalcab" y sobre el paso que cruza "La Sabana"..... .81

Figura 37. Auto denominación del asentamiento para generar el sentido de identidad .82

Figura 38. Sistemas constructivos tradicionales y en proceso de consolidación............................83

Figura 39. Mosaico fotográfico sobre camino "Norte" que atraviesa el humedal...........................83

Figura 40. Configuración espacial por la relación humedal-terrenos.............................................84

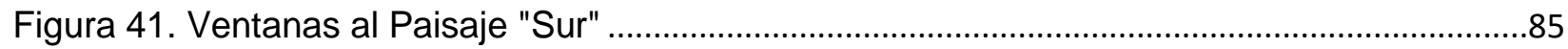

Figura 42. Ventana al paisaje "Centro", continuación Av. Maxuxac .............................................85

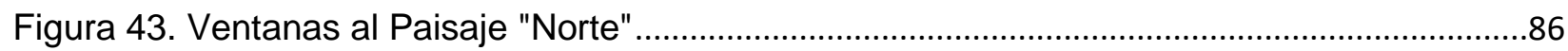

Figura 44. Mosaico: Los caminos como puntos de encuentro .....................................................86

Figura 45. Visuales, puntos focales y nodos de encuentro social del humedal "La Sabana" .......88

Figura 46. Chetumal, Grado de Marginación por AGEB Urbana, 2005......................................91

Figura 47. Chetumal, Grado de Marginación Urbana por AGEB, 2010........................................93

Figura 48. Grado de Marginación por AGEB Urbana, en "La Sabana", 2010 ...............................94

Figura 49. Unidades de Gestión Ambiental (UGA's) asignadas por el Programa Ecológico

Territorial de la Región de Lagua de Bacalar, 2005. ..................................................................101

Figura 50. Estrategia Urbana en Función de Ordenamiento Ecológico. ........................................105

Figura 51. Plano de Zonificación secundaria -Usos de suelo; localización del parque urbano "La

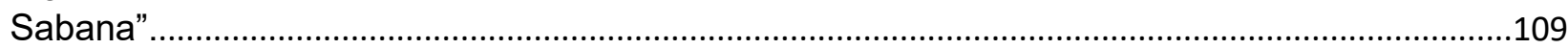

Figura 52. Impactos ambientales sobre el humedal "La Sabana" ........................................119

Figura 53. Mapa de Potencialidades y Limitantes del humedal "La Sabana". Escala de la Ecología del Paisaje o de funcionamiento natural del humedal. ..................................................124

Figura 54. Mapa de Potencialidades y Limitantes de "La Sabana". Escala a nivel urbanopaisajístico ...........................................................................................................................125

Figura 55. Mapa de Potencialidades y Limitantes de "La Sabana". Escala de relación urbana paisajística con el humedal "La Sabana".

Figura 56. Propuesta de incorporación del humedal "La Sabana" al ANP Estatal "Reserva

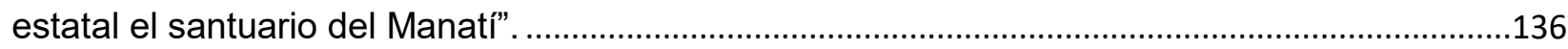

Figura 57. Zonificación General para el manejo del humedal "La Sabana".................................137

Figura 58. Zonificación preliminar "La Sabana".........................................................................138

Figura 59. Zonificación del humedal "La Sabana" ......................................................................140

Figura 60. Plan Maestro Paisajístico y Ambiental para el humedal "La Sabana" ........................143

Figura 61. Plan Maestro Zona Sur "La Sabana" ........................................................................144

Figura 62. Plan Maestro Urbano Paisajístico y Ambiental "La Sabana" Centro ..........................145

Figura 63. Plan Maestro Urbano Paisajístico y Ambiental para el humedal "La Sabana",

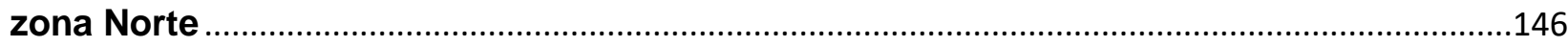

Figura 64. Plan Maestro Urbano Paisajístico y Ambiental para "La Sabana" Cabecera Norte ..147

Figura 65. Plan Maestro y actividades compatibles para el Humedal "La Sabana" ....................148

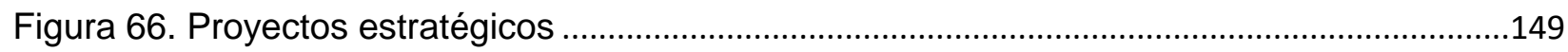

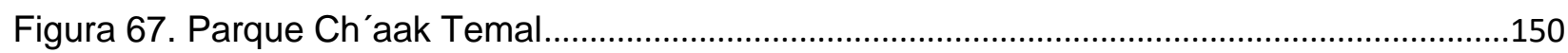

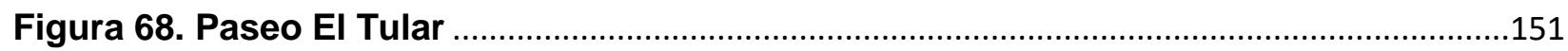


Figura 69. Paso a Desnivel "La Sabana". 152

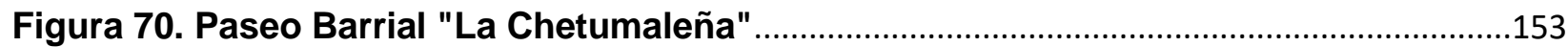

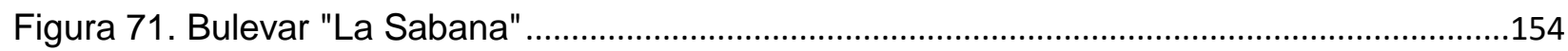

Figura 72. Circuito ciclista y peatonal "Humedales" .....................................................................155

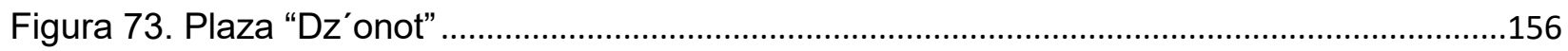




\section{INTRODUCCIÓN}

El Plan Maestro Urbano Paisajístico para el Humedal "La Sabana”, es un caso de estudio que comprende un área natural que tiene una gran relación con el paisaje cultural (paisajes cotidianos) de la ciudad de Chetumal, dicha relación ha significado una presión urbana constante sobre este cuerpo de agua, que ha afectado su funcionamiento natural y su calidad paisajística. Este trabajo de investigación, busca analizar las causas y consecuencias de la intervención humana en el área de estudio y presentar una propuesta coherente que permita la integración armónica de "La Sabana" con el desarrollo urbano de la ciudad de Chetumal, rescatando y conservando sus cualidades ambientales y paisajísticas, a la vez que se dota a la ciudad de un espacio de recreo e integración social y urbana, conservando y fortaleciendo la identidad del lugar.

Para resolver el problema planteado se pretende abordar el tema desde diferentes enfoques; el natural o ecológico, procurando reconocer el funcionamiento del humedal y su área de influencia hídrica; el urbano, para reconocer la dinámica del desarrollo urbano de la ciudad de Chetumal, en lo que se refiere a las características de los asentamientos humanos y los usos de suelo, la necesidad de conectividad y movilidad, los requerimientos para la dotación de parques y jardines públicos, zonas verdes y equipamientos urbanos compatibles, así como los criterios generales para prefigurar un plan maestro de diseño paisajístico-urbano, mediante el cual se propongan las acciones de rescate, integración y conservación del lugar.Para ello se reconocen los diversos elementos que integran la dimensión natural, urbana y paisajística de la zona de estudio, entre los cuales puede mencionarse en la dimensión natural las características hidrológicas del humedal, el uso de suelo y vegetación, los aspectos topográficos; mientras que en la dimensión urbana: aspectos como el territorio, población, actividades económicas, rasgos culturales; y en la dimensión paisajística los aspectos perceptuales. Por otro lado, será importante reconocer el estado actual en el que se encuentran, identificar compatibilidades e incompatibilidades de uso y actividades, plantear escenarios de desarrollo y delinear las propuestas de intervención. En este sentido, el 
trabajo está estructurado de la siguiente manera: en el apartado de Introducción se señalan los antecedentes del tema, el planteamiento y delimitación del problema, el objetivo, la hipótesis general y las motivaciones para elaborar la investigación.

En el Marco Teórico se abordan los fundamentos teóricos conceptuales que dan sustento al desarrollo de la investigación, los cuales se desprenden de los postulados teóricos de las corrientes de pensamiento conocidas como la Escuela de Chicago, la Ecología Urbana y la Ciudad Jardín, así como las nociones derivadas de la concepción contemporánea del paisaje y la ecología del paisaje.

En lo concerniente a la definición y caracterización de humedales, se describirán con la profundidad necesaria sus características, funcionamiento y los servicios ambientales que aportan a la comunidad, sin dejar de lado conceptos asociados a la resiliencia del paisaje y reconocer el paisaje y los humedales como una estrategia de adaptación al cambio climático.

En la construcción del estado del arte con respecto al humedal "La Sabana", se muestran los avances del conocimiento en el tema, a través de la lectura de diversas contribuciones académicas y publicaciones especializadas sobre el caso de estudio, y se aborda el marco conceptual sobre el cual se circunscribe el abordaje de la investigación.

En el Marco Metodológico se exponen los objetivos e hipótesis, las preguntas que guían la investigación y la metodología seleccionada; finalmente en el Marco Operativo se aborda el desarrollo de los temas relacionados con el humedal y el entorno urbano y paisajístico, el cual se integra por los siguientes apartados: Caracterización del sitio, donde se describe los principales atributos de los elementos que conforman el estudio, desde lo natural, lo urbano, lo social y paisajístico, además de incluir los aspectos normativos que inciden sobre el humedal.

Diagnóstico integrado, en este apartado se abordan los aspectos anteriores identificando las relaciones que existe entre ellos, y las principales problemáticas, así como las potencialidades y limitantes en la zona de estudio, para definir posteriormente 
los posibles escenarios para el humedal así como alternativas de intervención.Lineamientos ambientales, urbanos, paisajísticos y sociales para el humedal "La Sabana", que se definen con base a los parámetros anteriores, estableciendo los propios lineamientos que permitan alcanzar estos objetivos.

Plan Maestro Urbano Paisajístico para el Humedal "La Sabana", en este apartado se sintetizan las propuestas sobre el espacio físico que abarca el humedal; contemplando la definición de proyectos estratégicos que dan estructura y coherencia a la relación urbana, paisajística y ambiental entre la ciudad de Chetumal y el humedal motivo de este estudio.Conclusiones, finalmente presentan los resultados de la investigación, y las conclusiones, se presentan las propuestas y se emite una serie de recomendaciones.

\section{Antecedentes}

Los humedales son importantes para la conservación del paisaje, son fuente de abastecimiento de agua dulce, ofrecen servicios ambientales y culturales a la población, y se destaca, en el caso específico de la ciudad de Chetumal, el control de inundaciones dada su colindancia con el área urbana actual, y con el área de crecimiento planteada en el Programa de desarrollo urbano del centro de población. El Manual de la Convención de Ramsar $^{1}$ (Secretaría de la Convención de Ramsar, 2006) define a los humedales como cualquier área cubierta por agua dulce poco profunda, por lo menos durante una parte del ciclo anual, son zonas donde el agua es el principal factor controlador del medio y la vida vegetal y animal asociada a él. Además deja de manifiesto la importante interacción que existe entre el suelo, agua, las plantas y los animales, relación que se tomará en cuenta para la delimitación del humedal en capítulos posteriores; dichas condiciones permite a los humedales fungir como receptor y almacenador de agua, protección contra tormentas y mitigación de crecidas, tal cual ha sido en el caso de estudio; estabilización de costas, generando, de acuerdo a lo observado en "La Sabana" selva de galería o ribereña, lo que permite el control de la erosión; además de otros servicios ambientales

\footnotetext{
${ }^{1}$ La Convención sobre los Humedales de Importancia Internacional, conocida como la Convención de Ramsar, es un acuerdo internacional que promueve la conservación y el uso racional de los humedales; recibe su nombre por la ciudad iraní donde se firmó el tratado en 1971. Fuente de ref: https://www.ramsar.org/sites/default/files/fs_6_ramsar_convention_sp_0.pdf
} 
vitales como: recarga de acuíferos (movimiento descendente de agua del humedal al acuífero subterráneo); descarga de acuíferos (movimiento ascendente de aguas que se convierten en aguas superficiales en un humedal); depuración de aguas; retención de nutrientes; retención de sedimentos; retención de contaminantes; estabilización de las condiciones climáticas locales, particularmente lluvia y temperatura (Secretaría de la Convención de Ramsar, 2006). Del mismo modo juega un papel importante en el desenvolvimiento cultural, recreativo y económico de los pueblos, al proveer abastecimiento de agua y nutrientes para cultivos, pesca, así como las posibilidades de recreación y turismo.

Por su parte la Convención Marco de las Naciones Unidas sobre el Cambio Climático llevada a cabo en Copenhague, en 2009, señala la importancia de los humedales como ecosistemas frágiles que se encuentran amenazados por los efectos del cambio climático y las actividades humanas, y los reconoce como elemento clave para la adaptación y mitigación ante estos cambios globales, destacando que las políticas y la planificación se debe realizar a escala global y local.

Por ello, es necesario adoptar medidas para: reducir la degradación de las cuencas hidrográficas debida a la deforestación; incrementar la forestación; mantener y restaurar humedales ribereños y las llanuras inundables a lo largo de los ríos de modo que puedan ofrecer mejor protección contra las inundaciones; mejorar el manejo de los humedales y el agua al nivel de la cuenca; restaurar la infraestructura verde siempre que sea posible. (Ramsar, 2010).

Por su parte la CONANP, SEMARNAT (2015) destaca, en el documento "Estrategia de Cambio Climático desde las Áreas Naturales Protegidas: Una Convocatoria para la Resiliencia de México (2015-2020)", que la colaboración entre los distintos sectores involucrados en el manejo de los ecosistemas y aquellos que se benefician de los servicios ecosistémicos, así como una visión de paisaje y diagnóstico de impactos son necesarios para identificar detonadores de vulnerabilidad, y que a partir del cual, para el caso de "La Sabana" permitirá proponer alternativas de solución, ello en concordancia 
con el objetivo 11 de la Agenda² $^{2}$ 2030, la cual establece lograr que las ciudades sean más inclusivas, seguras, resilientes y sostenibles, lo cual obliga a que la planeación urbana establezca los mecanismos y proyectos para lograrlo; de este modo, la problemática no solo es un impacto en el ámbito del territorio local, si no estatal.

La importancia de incorporar a los humedales en los procesos de planificación de las ciudades o de los territorios, se ha abordado desde diferente índole y con distintos enfoques y objetivos; entre ellos el Plan Maestro del Gobierno Regional del Callao 20092014, el cual considera como Área de Conservación Regional a los Humedales de Ventanilla, y se utiliza como un instrumento de gestión que orienta las acciones a desarrollarse en esa región, sobre todo en la recuperación, reactivación productiva y económica de los pueblos.

Así mismo, la relación de los humedales con el desarrollo urbano está abordada por diferentes investigaciones; en el caso particular de "La Sabana", Luz Rangel (2015) señala el crecimiento de la mancha urbana hacia el humedal hasta que este funge como un límite natural al crecimiento urbano de la zona noreste de la ciudad. Este fenómeno urbano relevante, permitió incorporar a "La Sabana" en la planeación de la ciudad en el "Programa de Desarrollo Urbano de Chetumal, Calderitas, Subteniente López, Huay-Pix y Xul-Ha. Municipio de Othón P. Blanco", publicado el 27 de marzo de 2018 en el periódico oficial del Estado de Quintana Roo (en adelante PDU, 2018). Planteamiento que refleja una intención ambivalente para el uso del humedal: como parque urbanometropolitano o Área Natural Protegida.

Por su parte este crecimiento urbano hacia "La Sabana", trajo consigo una presión constante hacia el humedal, así como efectos adversos de contaminación ambiental y paisajística. En este sentido, los primeros asentamientos humanos que se dieron en las inmediaciones del humedal eran de tipo irregular por lo que, al no ser reconocidos por el Ayuntamiento, no disponían de los servicios públicos municipales básicos como el

\footnotetext{
${ }^{2}$ En el contexto internacional, la Asamblea General de la ONU adoptó la Agenda 2030 para el Desarrollo Sostenible.
} 
drenaje; esta colonia denominada "Los Monos" resolvió esta necesidad vertiendo directamente sus aguas servidas a fosas sépticas, mismas que, sin el tratamiento adecuado han contaminado el manto freático y el humedal.Por otro lado, la intervención de particulares mediante prácticas inadecuadas y prohibidas ha dado lugar a que diversos puntos del humedal, sean rellenados con materiales de desperdicio o escombro, para desplantar caminos de terracería e incluso nuevas construcciones, mermando los flujos de agua, fauna y nutrientes, afectando el funcionamiento natural de este sistema.

Por su parte, si bien, su origen no está formalmente reconocido, las colonias irregulares colindantes con el humedal exigen un mayor control sobre este cuerpo de agua, aquejándose de la contaminación, fauna nociva e inundaciones. Cabe destacar que en "La Sabana" todavía se realizan actividades productivas como la pesca, actividad que sirve de sustento a algunas familias y otras de carácter recreativo como el canotaje, la observación de aves y naturaleza.

Por lo anteriormente citado, se reconoce el potencial del humedal como elemento del espacio público capaz de fungir como enlace o una oportunidad para integrarse y ordenar el crecimiento urbano de la ciudad, con equipamientos urbanos culturales que propicien el uso adecuado y compatible con "La Sabana".

"La Sabana", entonces, se combina con la necesidad de conservar un espacio sumamente relevante para mantener el equilibrio ecológico e hídrico en la región, generando beneficios ambientales, urbanos y paisajísticos al centro de población circundante. Destacando la importancia y urgencia de generar una propuesta de intervención que permita integrar las variables del paisaje, para dotar a la ciudad de un espacio de calidad que permita valorizar la zona y propiciar la integración social con actividades compatibles con "La Sabana", con las necesidades urbanas, proveyendo de áreas verdes para el esparcimiento y contemplación, de valor ecológico, estético y funcional; y con ello una oportunidad para la valorización, rescate y conservación de este elemento de carácter ambiental y paisajístico, con un triple beneficio: la conservación del humedal, un desarrollo urbano integral, y el beneficio social.Todo ello a partir de un Plan 
Maestro que incluirá una zonificación primaria y la identificación de proyectos estratégicos compatibles con los objetivos de la planeación urbana con relación al humedal, presentando a grandes rasgos los esquemas conceptuales de las acciones urbanas y paisajísticas para el mejoramiento, recuperación y puesta en valor del humedal "La Sabana".

\section{Planteamiento y delimitación del problema}

Como se manifiesta, existen múltiples objetivos con respecto del humedal "La Sabana", sin embargo, poco se aborda en relación a los valores estéticos del paisaje y su relación con la población, así mismo no considera aspectos como movilidad sustentable integradas al paisaje, pero principalmente no establece cómo se va a realizar el planteamiento de todos esos objetivos al interior del polígono del parque urbano "La Sabana".

En resumen, el humedal "La Sabana" ha sido impactado negativamente y presenta una presión constante por el crecimiento urbano de la ciudad de Chetumal, por ello, se requiere incluir en el desarrollo de la ciudad este elemento de carácter paisajístico, para fomentar un uso compatible con las actividades urbanas, a la vez que se mejora su estado de conservación.

El problema a atender es la integración paisajística del humedal "La Sabana" a su entorno inmediato urbano y natural, con actividades compatibles para el uso y disfrute de la población. En ello reside reconocer el humedal como un sistema natural; las necesidades urbanas de movilidad, conectividad, áreas de recreo y equipamientos compatibles; y las propias aspiraciones de diseño del paisaje. Este tratamiento del paisaje desde distintos enfoques permite comprender el fenómeno en su conjunto, integrando diversas variables que darán un resultado más lógico y armónico, acorde a su realidad territorial, urbana y social. 
Nuestra zona de estudio específica, será delimitada por los límites topográficos que indican la escorrentía a manera de microcuenca, la asociación de vegetación y uso de suelo de las cartas del INEGI, más el área urbana adyacente al humedal; dichos límites conforman la etapa de desarrollo de la investigación por lo que serán definidos más adelante. Dentro de este polígono se definirán las estrategias medioambientales, urbanas y paisajísticas para el humedal "La Sabana", a partir de un Plan Maestro que defina una zonificación primaria y la identificación de proyectos estratégicos compatibles con los objetivos de la planeación urbana con relación al humedal, presentando a grandes rasgos los esquemas conceptuales de las acciones urbanas y paisajísticas para el mejoramiento, recuperación y puesta en valor de "La Sabana".

\section{Objetivo general}

Elaborar un Plan Maestro Urbano Paisajístico para el Humedal "La Sabana", que determine las estrategias, políticas y acciones, que permitan integrar armónicamente el humedal al desarrollo de la ciudad, a fin de potenciar su uso compatible con las actividades urbanas y mejorar su estado de conservación, para incrementar los beneficios que aporta al bienestar de la población.

\section{Hipótesis general}

El estudio y comprensión del funcionamiento natural del humedal, de sus cualidades paisajísticas y del entorno urbano, bajo las diferentes perspectivas de intervención: ecológica, paisajística y urbana, permitirán establecer los lineamientos de diseño urbano, paisajístico y ambiental articulados en un Plan Maestro, para el aprovechamiento, puesta en valor, salvaguarda y conservación del humedal "La Sabana".

\section{Motivación para elaborar la investigación}

Como se ha visto, el humedal "La Sabana" se encuentra bajo constante presión urbana, el crecimiento urbano ordenado dependerá de un planteamiento que integre los aspectos ambientales, urbanos y paisajísticos, sin un plan específico el humedal estará condenado a sufrir un proceso irreversible de degradación ambiental y paisajística afectando sus 
valores y cualidades intrínsecas, lo que redundará en la pérdida de un elemento vital para el control de inundaciones en la zona norte de la ciudad, así como la oportunidad de contar con un gran parque urbano que coadyuve a incrementar la superficie de áreas verdes por habitante en Chetumal.

Por ello es esencial plantear una intervención paisajística y urbana que permitirá revalorar y resignificar el lugar, regular las actividades urbanas vinculadas a este, permitir la convivencia, aprovechar los servicios ambientales, fomentar el cuidado y la cultura hacia el medio ambiente. Tomando en cuenta que su permanencia y preservación ecológica son aspectos, en el marco de un proceso de planeación ordenada, sistemática y racional del sitio, acorde a las necesidades de los habitantes de la región.

Los beneficios esperados se pueden catalogar en la esfera de lo ambiental, lo social y lo económico, además de los impactos esperados en términos de la mitigación de los efectos negativos propiciados por su deterioro y las posibilidades que ofrece con relación a los procesos de adaptación al cambio climático, destacando la mejora de la salud de los ecosistemas, permitiendo la conectividad ecológica, mantenimiento y recuperación de hábitat de especies, la generación de bienestar físico y sicológico como espacio de cohesión y organización social propicio para actividades recreativas y de esparcimiento, así como el potencial que representa como un centro atractor de negocios, turismo y economía verde. Por otro lado, se contemplan también otro tipo de respuestas positivas como el incremento de la plusvalía inmobiliaria de las zonas aledañas, la captura de carbono, la reducción del efecto de la isla de calor, el mejoramiento de los procesos para el manejo de agua y su calidad, como el control de inundaciones, garantizar su suministro y abastecimiento para el consumo humano, el reúso y la recarga del acuífero; así como el fomento de la resiliencia en el sistema socio ambiental, entre otros.

\section{Procedimiento y Metodología}

Para abordar el humedal "La Sabana" y su relación con el ámbito urbano y paisajístico, se recurrirá a la técnica de investigación documental y de campo, utilizando el método de investigación cualitativo, que permita describir y comprender el fenómeno en estudio.Se 
parte de la premisa que para conocer el funcionamiento integral de "La Sabana" se deberá abordar desde las perspectivas natural, urbana, social y paisajística, así como las relaciones existentes entre estas esferas; para ello, el apartado técnico de la investigación se estructura en: Caracterización del sitio, Diagnóstico Integrado, y Lineamientos ambientales, urbanos, paisajísticos y sociales. En cada una de estas etapas sucesivas, se aborda lo natural como marco biogeofísico del desenvolviendo social, la fenomenología de lo urbano como un conjunto complejo de procesos que dan lugar a la apropiación territorial de un espacio dado para la construcción y desarrollo de las aglomeraciones urbanas; y lo social como todos aquellos aspectos en los que interactúa el hombre y sus efectos en las formas de apropiación y aprovechamiento del espacio natural y urbano. Al mismo tiempo, se analizan las relaciones entre estos, y se revisan otras variables como los aspectos identitarios y perceptivos del paisaje.

De manera particular, el estudio del entorno físico natural del humedal "La Sabana", además de definir sus características generales, pretende reconocer la asociación entre el cuerpo de agua, la vegetación, el uso de suelo, la edafología y la topografía, con el objeto de definir una delimitación lacustre y su zona ribereña. Cada una de estas características se presentan en diferentes capas de información cartográfica del INEGI, las cuales una vez sobrepuestas permite identificar coincidencias o divergencias espaciales y a partir de esto, se puede determinar una relación entre estos rasgos geográficos. Para efectos prácticos, este análisis se realizará utilizando herramientas tecnológicas de sistemas de información geográfica (SIG), con el software Arc Map versión 10.2 .

El análisis del crecimiento histórico de la ciudad de Chetumal y sus implicaciones en el grado de conservación y preservación del Humedal La Sabana, se realizará mediante la comparación de cartografía que revele el crecimiento histórico del área urbana de la ciudad en diferentes periodos de tiempo. El objeto de esta revisión y análisis es identificar la transformación que ha sufrido la estructura urbana de Chetumal, las principales tendencias de expansión urbana, su morfología, la dosificación de los usos de suelo, la configuración de las redes de infraestructura, la localización de los principales elementos 
de equipamiento urbano, las zonas cubiertas por los servicios públicos, las características básicas de la vivienda y la ubicación de parques y áreas verdes urbanas; así como de los asentamientos irregulares identificados a la fecha. Para validar la información derivada de los estudios fotogramétricos y del análisis de las imágenes satelitales o documentos cartográficos, se realizarán recorridos en campo.

Con respecto de la percepción del entorno urbano-arquitectónico y paisajístico, conviene precisar que el paisaje se constituye tanto por los aspectos físicos que lo componen como por la forma en que estos son percibidos; por ello es importante incluir la imagen urbana arquitectónica del lugar; así como sus rasgos paisajísticos más relevantes; los cuales contribuirán a definir la relación de la población con el sitio con respecto de la apropiación, identidad y valoración del lugar. Para ello se recurrirá al estudio de fotografías históricas y actuales recolectadas en recorridos de campo, así como el levantamiento de encuestas y cuestionarios a diversos actores sociales e informantes que conocen o tienen alguna relación con "La Sabana", sea de interés personal, profesional, académico o como servidores públicos.

El análisis del entorno social por su parte incluye el estudio de aspectos sociodemográficos, económicos y culturales, a efecto de comprender la estructura social del sitio, los rasgos culturales de la población y el nivel de calidad de vida, utilizando información estadística oficial (INEGI, SEDESOL), la cual estará vinculada a la plataforma cartográfica creada en el sistema de información geográfica mencionado anteriormente.

La revisión de los aspectos jurídico legales permitirá visualizar las directrices normativas que se ciernen sobre el humedal y su zona de estudio; principalmente el Programa de Desarrollo Urbano de la ciudad y la Ley General del Equilibrio Ecológico y Protección al Ambiente y su Reglamento ${ }^{3}$.

El análisis de los factores anteriormente señalados permitirá delinear el diagnostico integrado, el cual dará cuenta de una caracterización del sitio y permitirá identificar

\footnotetext{
${ }^{3}$ Reglamento de la Ley General del Equilibrio Ecológico y Protección al Ambiente
} 
claramente sus limitaciones y potencialidades, en los ámbitos de lo ambiental, urbano y paisajístico. A partir de esto, se identificará la problemática general, misma que, una vez revisada, permitirá delinear un esquema prospectivo mediante la delineación de escenarios alternativos de solución, como base para la construcción de la imagen objetivo del proyecto.

Finalmente, en el capítulo de Lineamientos de diseño ambiental, urbano, paisajístico y social para el humedal "La Sabana", se presentan los criterios de intervención, que guían las acciones específicas para alcanzar los objetivos ambientales, urbanos, paisajísticos y sociales que dan sentido al Plan Maestro y que permiten desarrollar la propuesta conceptual y proyectual de integración urbana y paisajística.

\section{Resultados y Aportaciones}

Entre las principales aportaciones está la Caracterización y Diagnóstico Integrado desde una perspectiva integral del sistema urbano y del paisaje, lo que permite incorporar información base para estudios posteriores más específicos en el campo de la arquitectura, el urbanismo y el paisajismo. Su importancia radica en centrar el interés de análisis de la zona de estudio bajo escalas espaciales distintas y complementarias: territorial, urbana y de sitio para comprender el fenómeno en su conjunto, a partir de lo cual se podrán establecer los criterios paisajísticos ambientales y urbanos de un entorno determinado, enfocado a la planificación, conservación y puesta en valor.

Como resultado se pretende elaborar el Plan Maestro Urbano Paisajístico para el humedal "La Sabana", en el cual se incorporan las variables enumeradas en el apartado anterior, y se definen espacialmente las propuestas de integración entre la ciudad y el humedal, a través de un sistema de áreas verdes urbanas que fungen a la vez como corredores biológicos, mismo que una vez implementados aportarán beneficios sociales, ambientales, urbanos, paisajísticos, culturales y económicos, mismos que ya se han planteado con anterioridad. 


\section{MARCO TEÓRICO}

\section{La Escuela de Chicago y las nociones de Ecología Urbana, y la Ciudad Jardín}

El objetivo de este tema es introducir las principales ideas de la denominada ecología urbana propuesta por los sociólogos de la escuela de Chicago, entre 1915 y 1938 y la ciudad jardín de Ebenezer Howard en Inglaterra, en 1898 y establecer la relación que existe con nuestro tema de estudio.La primera está referida a un cuerpo o modelo teórico de distribución-segmentación social de la población en el espacio, derivada de la competencia y cooperación de los ciudadanos, a semejanza de la localización y distribución de plantas y animales tras un proceso de competencia y selección, razón por la cual se le denominó como ecología urbana; y la segunda, está referida al modelo de una ciudad ideal que comparte los beneficios de establecer a sus habitantes en un ambiente "rural" compatibles con los propios de una ciudad: acceso al trabajo, bienes y servicios (Sato, 1977).

A pesar de que el primer modelo pretende explicar la distribución social en el espacio a partir del análisis de la propia experiencia que vivieran los estudiosos de la ciudad de Chicago, y la segunda proponer un modelo conceptual para fundar una ciudad nueva e ideal, ambas surgen ante una realidad social urbana en detrimento, que ponía de manifiesto la urgencia del estudio de la ciudad y propuestas de solución.

Los postulados de la escuela de Chicago surgen como una reacción natural ante los fenómenos que se presentaban en la ciudad en la década de 1980, que pasaba por una dinámica de crecimiento extraordinaria, principalmente por la inmigración. En la obra de Lezama Teoría social, espacio y ciudad de 1993, en el capítulo referido a la Escuela ecologista clásica de Chicago, se explica el concepto de dominio, que por el aporte que resulta de su interpretación convendría exponer: está referido al dominio de las áreas naturales o funcionales en una comunidad metropolitana o por estar emplazadas territorialmente en puntos estratégicos o por desempeñar funciones decisivas en la vida comunitaria (Lezama, 1993); de manera semejante en el 2007 Chueca Goitia, refiere el factor de localización como la ventaja que una actividad económica obtiene de estar 
situada en un determinado punto, obteniendo de ello ventajas comparativas y competitivas de localización, donde se incluyen como variables puntos de consumo, producción, costos de transporte, distancias y mano de obra.

Otro concepto al que refiere Lezama (1993) es el de sucesión, en el que explica que todas las comunidades en su nivel biótico atraviesan por una serie sucesiva de cambios, que derivan de los procesos de adaptación y competencia que se dan entre los miembros de una comunidad o entre diversas comunidades. Con ello puede comprenderse el modelo de Burgess o esquema de los círculos concéntricos donde la sociedad se organiza de la siguiente manera:

En un primer momento (círculo central del esquema), la ciudad, como respuesta al crecimiento físico y poblacional, desborda la primera zona de asentamiento en cuyo interior está contenido el distrito comercial central. El resultado de esto es un primer momento de la diferenciación, que da lugar a la llamada zona de transición (zona II) en la cual se asientan la industria ligera y los negocios pequeños. La conformación de esta área empuja a sus antiguos moradores, los obreros, hacia una tercera zona en la cual se instalan, para escapar de las áreas deterioradas y con el propósito de ubicarse cerca de sus fuentes de trabajo. Posteriormente se forma una zona IV que se caracteriza por viviendas independientes y departamentos para las clases acomodadas. Por último, el proceso de expansión y diferenciación da lugar a los llamados suburbios (zona V) o ciudades satélites (Lezama,1993).

Este esquema ideal, estaría influenciado por un constante proceso de expansión y sucesión, acompañado de otro de concentración y descentralización, explicados estos últimos por las fuerzas económicas de mercado, y ecológicas, bajo el concepto de dominancia.

Lezama (1993) lo explica de la siguiente manera: 
El principio de dominación surge, tanto por la importancia que tienen estas actividades económicas, como por el establecimiento de un patrón de precios del suelo que deriva de la presión ejercida en la búsqueda de espacios disponibles en las zonas que garantizan mayores ventajas económicas; de esto resulta una revaloración del precio del suelo en el centro de la ciudad. A partir de los precios del suelo del área central se establece un gradiente que explica los de cada una de las áreas sucesivas que conforman el espacio urbano; surge así un patrón de usos del suelo para distintos grupos funcionales. De esta manera la ciudad y su patrón ecológico emergen de la lucha de las instituciones comerciales e industriales por localizarse estratégicamente en el entorno urbano (Saunders, 1986; Gottdiener, 1985).

El crecimiento de la ciudad que tiene la expresión física que ya se ha mencionado implica también un proceso de distribución que coloca a los hombres en determinadas posiciones en los ámbitos residenciales y habitacionales. Ésta es la forma que asume el fenómeno de la diferenciación mediante el cual la ciudad, al menos la norteamericana, termina adquiriendo un patrón socioespacial (Lezama,1993).

Bajo este contexto, los planteamientos de la escuela de sociología de Chicago podría explicar la razón económica ${ }^{4}$ de localización de la colonia Los Monos y otros asentamientos, sin los servicios básicos a la vivienda, alejado del centro económico de la ciudad, de los equipamientos, y de los lugares de trabajo, donde habiendo sido un asentamiento irregular la población encontraría los terrenos más baratos a los que pudo acceder: la localización de la población estaría en función de su capacidad económica, de acuerdo a los postulados de competencia=segregación social.

Por su parte, en Inglaterra, serían los propios problemas de la ciudad industrial los que fomentarían el surgimiento de los conceptos sociológicos y urbanísticos de Ebenezer

\footnotetext{
${ }^{4} \mathrm{Y}$ ecológica bajo el concepto de dominancia, pero prefiero referirme a los términos económicos.
} 
Howard para una ciudad ideal: la ciudad Jardín, que propugnaba la idea de compartir los beneficios de una ciudad localizada en el campo: "La realidad no consta sólo de dos alternativas, como es constantemente admitido -vida ciudadana y vida rural- sino de una tercera alternativa en la que pueden conjugarse en perfecta combinación todas las ventajas de una vida ciudadana decisivamente dinámica y activa(,) con la belleza y el deleite del campo" (Howard, 1902, en Sato, 1977).

A continuación, citaremos los principios con los que Howard (1902, en Sato, 1977) describía su ciudad ideal:

La ciudad está atravesada, del centro a la circunferencia, por seis magníficos paseos, [de 36.57 metros de ancho], cada uno de ellos la dividen en seis partes o distritos iguales. En el centro hay un espacio circular, que cubre [unas dos hectáreas], cubierto por un hermoso y bien regado jardín; rodeando este jardín están los grandes edificios públicos -ayuntamiento, sala principal de conciertos y conferencias, teatro, biblioteca, museo, sala de arte y hospital-, ubicados todos ellos en terrenos espaciosos e independientes.

El resto de este gran espacio encercado por El Palacio de Cristal consiste en un parque público, [de 58 hectáreas], provisto de amplias zonas de recreo de muy fácil acceso para todos. (...) con una forma circular que permite a todos los habitantes, distantes a un máximo de [medio kilómetro], un rápido acceso.

Esta ciudad radial concéntrica de Howard, albergaba las instituciones administrativas, culturales, de salud y recreativas en el centro de la ciudad, procurando una accesibilidad inmediata e igualitaria. Finalmente, las industrias, sitios de trabajo, almacenes y mercados se localizarían en el último cinturón o anillo exterior, con acceso a líneas de ferrocarril para su transporte (Howard, 1902, en Sato, 1977), [introduciendo otro concepto importante la movilidad al interior de las ciudades]. 
Por su parte las viviendas están dispuestas de frente a las avenidas o lindando con los paseos y carreteras que convergen en el centro de la ciudad, y que su construcción obedece a disposiciones regulatorias a cargo del municipio. Por otro lado, destinaría un espacio para escuelas e iglesias con terrenos circundantes de recreo y jardín. (Howard, 1902, en Sato, 1977).

Como se aprecia la ciudad jardín incorpora beneficios esperados por servicios administrativos, equipamientos, infraestructura con accesibilidad para todo el conjunto, paseos y jardines; por su configuración es fácil imaginar el humedal "La Sabana", cumpliendo con estas características como elemento central a partir del cual se organiza un espacio urbano ligado a la naturaleza.

\section{El nuevo urbanismo y la sustentabilidad}

Miranda Rosales y Jiménez Sánchez (2011) exponen en su publicación "Sustentabilidad urbana planteamientos teóricos y conceptuales" los antecedentes teóricos del desarrollo sustentable hasta converger hacia la acepción de lo urbano y las características de la ciudad sustentable, estableciendo seis parámetros que inician con un lugar que cuente con todas las provisiones necesarias para la vida urbana, en ciudades más compactas, densificando a la población y concentrando actividades para incrementar las interacciones sociales, y facilitar la accesibilidad y la conectividad a través del transporte público y modos no motorizados hacia los equipamientos, servicios y áreas verdes. El segundo aspecto a considerar incluye un fundamento básico de diseño, que de acuerdo al autor se refiere a "Un orden visual y funcional, un ambiente controlado, un lugar libre de contaminación y ruido" que incluye un lugar seguro en un ambiente libre de contaminación, ruido, congestión, accidentes y crimen, pero además, a manera de la ciudad jardín de Ebenezer Howard, viviendas privadas ajardinadas, y por otro lado en el concepto espacial urbano espacios abiertos ligados directamente con la naturaleza, y ciudades productivas autosuficientes. El tercer aspecto está dirigido a generar un ambiente social propicio, donde se genere un sentido de comunidad y pertenencia, con una mezcla de estratos sociales en altas densidades. Por su parte, el cuarto parámetro 
se enfoca en proveer un lugar con una buena imagen, reputación y prestigio, que genere confianza, estatus y dignidad; en este mismo nivel los autores integran una ciudad autosuficiente en términos de empleo, energía, agua, con una visión de la ciudad como productora de bienes. Bajo este esquema general se espera que la ciudad brinde las condiciones oportunas para incentivar la creatividad (punto número cinco), en un ambiente estético y agradable, aspecto número seis, bien diseñado, identificable, un lugar para la cultura y el arte. (Miranda Rosales y Jiménez Sánchez, 2011). Como puede observarse: naturaleza, economía, comunidad e identidad son aspectos fundamentales de la ciudad sustentable, todos estos aspectos se integrarán en la propuesta del Plan Maestro para el humedal "La Sabana".

Finalmente, Miranda Rosales y Jiménez Sánchez (2011) incluyen en sus conclusiones "el manejo de un análisis y diseño integral de escalas como parte importante del proceso de análisis, que va de la región al objeto arquitectónico, como parte del proceso de diseño, con el objeto de identificar cada propuesta en todos los ámbitos urbanos"; aseveración que fundamenta la inclusión de la escala regional, urbana y arquitectónica a nuestro caso de estudio.

\subsection{Estado del arte}

El humedal "La Sabana" ha sido abordado por estudiosos de la ciudad y del medio ambiente, entre ellos la tesis de grado elaborada por Luz Rangel (2015) presenta, como eje de estudio, el crecimiento urbano de la ciudad por periodos de tiempo, hasta que este se ve frenado por el humedal, fungiendo este último como límite físico natural a la expansión urbana; en este recorrido incorpora problemáticas originadas por asentamientos irregulares, encuestas de percepción del entorno ambiental y social que reflejan la inseguridad de la zona, la contaminación por tiradero de basura a cielo abierto, presencia de mosquitos y en general una baja valoración social del entorno del humedal.

Otros estudios se enfocan en la calidad del agua presente en el humedal, elaborados por la Universidad de Quintana Roo, y en parásitos encontrados en los peces, dado que la pesca es una actividad de autoconsumo que se realiza con frecuencia en "La Sabana". 
Sin embargo, no existe hasta el momento alguna investigación que delimite el humedal y que realice una propuesta de intervención urbano-paisajística. El Programa de Desarrollo Urbano de la ciudad de Chetumal (PDU, 2018) presenta una delimitación, pero no describe el procedimiento por el cual se determina ese polígono, además que este se "corta" o circunscribe en el polígono urbano sin establecer su continuidad regional.

Por otro lado, se encuentran ejemplos y estudios de aprovechamiento de humedales para el ordenamiento de la ciudad, por mencionar un ejemplo se incluye el caso del Plan Maestro Humedales (en ADNea Revista de Arqutiectura y Diseño del Nordeste Argentino, Vol. 5), como parte de un grupo de iniciativas regionales que la gestión de esa provincia ha priorizado en materia de planificación integral, y que tiene por objetivo aportar al gobierno un instrumento para la gestión integral del territorio que colabore en el fortalecimiento de su accionar en relación con la conservación y gestión sustentables del Humedal Chaco:

(...) que colabore en el fortalecimiento de su accionar en relación con la conservación y gestión sustentables del Humedal Chaco y su biodiversidad, que apunte a potenciar las características productivas y turísticas del lugar garantizando la sustentabilidad del ecosistema junto con la mejora de los indicadores y condiciones socio-territoriales de la población residente. Producto de ese proceso, el Plan Maestro Humedales expresa los lineamientos de la política pública establecidos por la actual gestión del gobierno de Chaco y define una serie de estrategias singulares para el desarrollo sustentable en orden a sus características naturales, culturales y socioeconómicas, y propone un abanico de acciones que van desde las obras de pequeña escala — paseos, miradores, parques- a obras estratégicas de logística como puertos, puentes, rutas y energía, que potencian el desarrollo productivo de la provincia.

Dada la escasez de trabajos que aborden directamente las condiciones ambientales del humedal y su relación con el fenómeno urbano, las contribuciones anteriormente citadas sirven como punto de partida analítico para entender las relaciones existentes entre un 
sitio con estas características medio ambientales y paisajísticas y la población radicada en su entorno., desde una perspectiva social y económica.

\subsection{Marco conceptual}

En este apartado se incluyen algunos conceptos que sirven de base para la compresión del fenómeno de estudio.

\subsubsection{La concepción contemporánea del paisaje natural y paisaje cultural}

El paisaje está integrado por el soporte territorial o natural de un espacio determinado, más las cualidades estéticas, y los valores que les atribuye la población que interactúa con él; valores que pueden estar asociados con factores ambientales-ecológicos, económicos-productivos, religiosos, o bien históricos. El Convenio Europeo del Paisaje (2000) define al paisaje como "cualquier parte del territorio tal como la percibe la población, cuyo carácter sea el resultado de la acción y la interacción de factores naturales y/o humanos"; donde el ámbito de aplicación "abarcará las áreas naturales, rurales, urbanas y periurbanas. Comprenderá asimismo las zonas terrestres, marítima y las aguas interiores. Se refiere tanto a los paisajes que puedan considerarse excepcionales como a los paisajes cotidianos o degradados."; en este sentido el humedal "La Sabana" puede entenderse como un área natural situada en la periferia urbana, con características que se podrían calificar desde lo excepcional, hasta lo cotidiano y degradado.

Así mismo, y continuando con las aportaciones que sobre la definición de paisaje se han hecho, y que enfatizan la relación del hombre con su medio, destaca la presentada en la iniciativa de la Convención Internacional del Paisaje y el marco de la reunión de expertos en París (2010), donde los especialistas proponen la siguiente definición del paisaje como base para un nuevo instrumento jurídico 5 : "el paisaje se define como un espacio/tiempo resultado de factores naturales y humanos, tangibles e intangibles, que al ser percibido $y$

\footnotetext{
${ }^{5}$ La Iniciativa Latinoamericana del Paisaje, (LALI por sus siglas en inglés) [en línea], 30 de agosto de 2012 [ref. de 07 de mayo de 2016]. Disponible en: <

http://www.upv.es/contenidos/CAMUNISO/info/U0671043.pdf>.
} 
modelado por la gente, refleja la diversidad de las culturas".Al respecto la Carta Mexicana de Paisaje (2011) refiere que "el paisaje se considera como un bien de interés público que al integrar el ambiente natural y las manifestaciones humanas, sociales y culturales, se constituye en un factor de calidad de vida, fuente de armonía y placer estético"6. Estas consideraciones ponen de manifiesto la indisoluble relación que tiene el hombre con el territorio, y que con ello se constituye la propia definición de paisaje; sin embargo deja claro dos situaciones que se manifiestan en él: los aspectos naturales, asociados a las propias relaciones bióticas y abióticas en el territorio, y los aspectos culturales, relacionados con las manifestaciones humanas, que tienen que ver con sus transformaciones, aprovechamiento y apropiación de esos espacios.

Lo anterior se ve reforzado en la Convención sobre la Protección del Patrimonio Mundial Cultural y Natural (1972), en la cual se definen por separado el patrimonio cultural y el patrimonio natural, las cuales se señalan en el artículo primero y segundo ${ }^{7}$. Dichas definiciones se ratifican en las Directrices Prácticas para la aplicación de la Convención del Patrimonio Mundial (2016), pero también anexa la definición de Patrimonio mixto cultural y natural, y se incorpora la definición de Paisajes culturales siguiente: "Los paisajes culturales son bienes culturales y representan las "obras conjuntas del hombre y la naturaleza" citadas en el Artículo 1 de la Convención. Ilustran la evolución de la sociedad humana y sus asentamientos a lo largo del tiempo, condicionados por las limitaciones $y / 0$ oportunidades físicas que presenta su entorno natural y por las sucesivas fuerzas sociales, económicas y culturales, tanto externas como internas." 8

\footnotetext{
${ }^{6}$ Carta mexicana de paisaje [en línea]. Sociedad de Arquitectos Paisajistas de México, 2011 [ref. de 07 de mayo de 2016]. Disponible en web: < https://paisajesculturales.files.wordpress.com/2013/03/cmp_final.pdf>.

7 Dichas definiciones están disponibles en: Convención sobre la Protección del Patrimonio Mundial Cultural y Natural 1972 [en línea]. París, 16 de noviembre de 1972 [ref. de 09 de mayo de 2016]. Disponible en web:< http://portal.unesco.org/es/ev.phpURL_ID=13055\&URL_DO=DO_TOPIC\&URL_SECTION=201.html >.

8 Directrices Prácticas para la aplicación de la Convención del Patrimonio Mundial [en línea]. París, enero de 2008 [ref. de 09 de Mayo de 2016]. Disponible en web: < http://whc.unesco.org/archive/opguide08es.pdf>.
} 
En esta última definición de paisaje cultural, se manifiesta la relación entre el hombre y la naturaleza, integrando en un solo concepto los aspectos naturales y culturales, introduciendo el factor tiempo; y donde el objeto de estudio, en este caso el humedal "La Sabana", tiene el potencial de formar parte de un paisaje vivo que evolucione, con las necesidades actuales de la población, de la ciudad y del medio natural en su conjunto, reconociendo así la importancia del humedal, como elemento de integración paisajístico, ambiental, urbano y social.

Como vemos, el paisaje se constituye por diversos elementos, que tendrán que considerarse al momento de abordar un estudio de esta naturaleza: multidisciplinaria, multiescalar y también con una multiplicidad de métodos para abordar el estudio del paisaje, o que intervienen en él; lo que necesariamente da pie a incluir conceptos asociados como: ecología del paisaje, urbanismo ecológico, cambio climático y resiliencia del paisaje. Donde, para efectos de este proyecto, podemos establecer que desde la perspectiva de la ecología del paisaje debe contemplarse el funcionamiento natural de "La Sabana" y su relación con el sistema de humedales; desde el urbanismo ecológico, se pueden reconocer los impactos y presiones urbanas, minimizándolas, pero a la vez incrementando los factores de movilidad y reconociendo al humedal como una oportunidad de integración socioespacial y urbana, de interconexión-distribución y donde converge múltiple información y actividades, pero sobre todo procurando un sistema de áreas verdes urbanas, generando corredores y nodos (que también forma parte de la ecología del paisaje).Por su parte abordar temas asociados al cambio climático, permitirá reconocer posibles escenarios futuros y sus impactos en el ambiente y la ciudad, y con ello establecer las medidas sobre el humedal y su entorno inmediato que permitan mitigar, adaptar y generar una capacidad mayor de enfrentar esos posibles cambios, es decir, incrementar su capacidad de resiliencia.

\subsubsection{Ecología del paisaje}

De acuerdo a Josep Vila Subirós (et. Al, 2006): podemos definir la landscape ecology como una visión holística de la realidad que intenta integrar al máximo su extremada y dinámica complejidad. Una visión de síntesis fundamentada especialmente en la 
incorporación, por una parte, de la interpretación de la heterogeneidad horizontal, un enfoque propio de la geografía que centra su atención en la distribución de los paisajes a lo largo del territorio. $Y$, por otra parte, el análisis de la heterogeneidad vertical, una perspectiva propia de la ecología, que hace hincapié en la interrelación entre los distintos elementos bióticos y abióticos en una porción determinada de paisaje. Por su parte Forman (1983) define a la ecología del paisaje como el estudio de las interacciones entre los aspectos temporales y espaciales del paisaje y sus componentes de flora, fauna $y$ culturales. Se centra en:

- Las relaciones espaciales entre elementos del paisaje o ecosistemas.

- Los flujos de energía, nutrientes, minerales y especies entre los elementos.

- La dinámica ecológica del mosaico paisajístico a lo largo del tiempo?.

Se puede afirmar que el paisaje está formado por tres componentes principales:

Estructura: es la organización espacial de los elementos o usos del territorio (matriz, mancha, corredor).

Función: es el movimiento o flujo de agua, materias, fauna o personas a través de la estructura.

Cambio: es la dinámica o transformación del modelo a lo largo del tiempo ${ }^{10}$.

Mientas que el mosaico territorial se compone de sólo tres tipos de elementos: matriz o trama, manchas y corredores. Este modelo matriz-mancha-corredor controla fuertemente todos los movimientos, flujos y cambios de los sistemas naturales y de la población. La ecología del paisaje observa los cambios en las propiedades de estos tres elementos y sus efectos sobre el ecosistema ${ }^{11}$.

\footnotetext{
${ }^{9}$ Ecología del paisaje. Introducción [en línea] [ref. de 16 de mayo de 2016] Disponible en web: < http://www.escet.urjc.es/ pad/WEB2005/DOCENCIA/PAISAJE/01\%20ECOLOGIA\%20DEL\%20PAISAJE. pdf>

10 IDEM

${ }^{11}$ IDEM
} 
Con respecto de los elementos del paisaje o mosaico de paisaje, según P. Odum y Gary W. Barrett (2006) "el mosaico de paisaje puede considerarse como un área heterogénea compuesta de diversas comunidades distintas o de un grupo de ecosistemas de distintos tipos. La matriz del mosaico de paisaje está formada por ecosistemas que son bastante similares en función y origen" esto permitiría diferenciar usos del suelo por el tipo de vegetación, por ejemplo, agrícolas, urbanos, selvas entre otros. Mientras que conviene diferenciar los parches y corredores de paisaje por su importancia para el caso de estudio: un parche de paisaje es un área relativamente homogénea que difiere de la matriz circundante, dependiendo de su cubierta de vegetación (P. Odum y Gary W. Barrett, 2006), aplicados al ámbito urbano se entenderían como manchones de vegetación especialmente en áreas verdes urbanas; mientas que un corredor de paisaje es una tira de entorno que difiere de la matriz que lo rodea por ambos lados y con frecuencia conecta (ya sea naturalmente o por diseño) dos o más parches de paisaje con un hábitat similar (P. Odum y Gary W. Barrett, 2006). Esto permitiría definir bosques de galería, en nuestro caso selvas o vegetación asociada a la ribera del humedal ${ }^{12}$.

Algunos de estos conceptos son retomados como estrategias para aplicarse en las ciudades, sobre todo en el urbanismo con bases ecológicas, me refiero a las redes de áreas verdes, lo que correspondería a parches y corredores sobre una matriz urbana. La importancia de las áreas verdes en las urbes ha retomado cada vez más importancia, y considerarla dentro de los elementos que componen la ciudad, como parte del paisaje, de los equipamientos, espacios de ocio y recreo, reconocen una oportunidad como elemento integrador de la ciudad. En este sentido convendría recuperar la concepción que se tiene de las áreas verdes, desde el urbanismo.

\footnotetext{
12 Karr y Schlosser (1978) y Lowrance et al. (1984) describieron cómo benefician al paisaje agrícola los corredores con vegetación en los ríos, interceptando la lixiviación de nutrientes y sedimentos de la tierra laboral que de lo contrario terminarían en la corriente del río contribuyendo a problemas de eutrofización cultural. Estas tiras no sólo mejoran la calidad del agua, sino que también reducen las fluctuaciones de nivel del río y ayudan a conservar la diversidad biótica natural dentro del mosaico de paisaje agrícola.
} 


\subsubsection{Urbanismo, sistema de espacios abiertos y áreas verdes urbanas}

Las nuevas concepciones del urbanismo buscan una integración de múltiples aspectos relacionados con la movilidad y accesibilidad, dotación de equipamientos, integración de usos de suelo, actividades y flujos de información, diseño urbano bioclimático, densificación, proximidad, entre otros, de los cuales destaca el lugar de las áreas verdes como parte de la urbe y como elemento con capacidad de integración social y espacial, a la vez que se procura mantener sus cualidades ambientales y estéticas, pero integrándolas a una escala al servicio de toda la ciudad. En este sentido conviene abordar lo que derivado de diversas perspectivas urbanísticas se vierte en relación a los espacios verdes urbanos y cuerpos de agua.

Al respecto, Ester Higueras (2012), en su libro titulado "Urbanismo bioclimático", reconoce la importancia de preservar la red de agua superficial de las zonas de arroyos o balsas de agua, como elementos relevantes y significativos de cualquier ordenación, estableciendo en ellos los usos adecuados para su aprovechamiento y mantenimiento yo agregaría el aspecto conservación, y que pueden convertirse en una red peatonal adecuada para usos recreativos o de relación social entre zonas urbanas. Preservar todos los cauces e integrarlos en la red de espacios libres y zonas verdes, de manera que se combinen con usos de ocio, deportivos, recreativos, etc., de la ordenación, además pueden ayudar a mejorar las condiciones del microclima local y aportar un valor estético invaluable.

Por su parte, es indispensable considerar una zona de servidumbre junto a estos cauces para evitar problemas de inundación, y establecer otros usos más adecuados como recreativos, zonas verdes, etc. Para lo cual será necesario realizar estudios y planos de zonas inundables.

Con respecto de la vegetación reconoce la misma autora que no es frecuente estudiar la localización, especies y porte de los árboles y vegetación, en los estudios y planes sobre el suelo urbano. Pero son éstos los elementos más completos para adaptar y proteger los espacios libres, para mantener el equilibrio del ecosistema urbano y favorecer la 
composición atmosférica, la velocidad del aire o la humedad ambiental ${ }^{13}$. Tal es su importancia que se ha incorporado el concepto de Sistemas de áreas verdes urbanas, Sistema de Espacios Abiertos, Infraestructura verde, entre otros, en el campo del urbanismo.Al respecto Antonio Suárez (et. Al, 2011) menciona que "Las estrategias de Infraestructura verde buscan un entendimiento entre las funciones ecológicas, sociales y económicas que brindan los sistemas naturales, esto con la finalidad de lograr un uso más eficiente y sustentable del territorio en la escala local, urbana y regional", entre ellas destaca que la infraestructura verde enfatiza la conservación de los recursos naturales dentro del ecosistema urbano; la infraestructura verde trabaja en pequeñas y grandes escalas integrando diferentes disciplinas; y que la Infraestructura verde es útil en la planeación urbana y contextualiza el crecimiento sustentable de las ciudades (Suárez Antonio, et. Al, 2011).Continuando con Suárez, una solución integral, característica de la infraestructura verde, implica el desarrollo no solo de modelos de permeabilidad o reforestación sino de movilidad no motorizada para disminuir las áreas de asfalto. Implica la creación de corredores de biodiversidad, parques lineales, nuevas áreas de espacio público y encuentro social, es decir, una estrategia para la inducción de una cultura de aprecio a la funcionalidad y estética del paisaje original. A diferencia de otros acercamientos a la conservación y manejo de los recursos naturales, la infraestructura verde se interrelaciona con la infraestructura planeada y hecha por el hombre, como las áreas urbanizadas y los futuros asentamientos humanos (Suárez Antonio, et. Al, 2011, pág. 2 y 3).

Por su parte el Reglamento para el Ordenamiento del Paisaje Urbano del Distrito Federal (2005) define los Espacios Abiertos, como predios de uso público destinados a deportivos, parques, plazas y jardines, donde se realizan actividades de esparcimiento, deporte y recreación en general, determinados como zonificación "EA" en los programas de desarrollo urbano; mientras que el Reglamento de Paisaje de Comunidad Valenciana

\footnotetext{
13 Urbanismo Bioclimático Criterios medioambientales en la ordenación de asentamientos [en línea], septiembre de 1998 [ref. de 25 de enero de 2017]. Disponible en web:

<https://es.scribd.com/doc/160817789/URBANISMO-BIOCLIMATICO>
} 
(Decreto 120/2006, de 11 agosto $^{14}$ ) se refiere a Sistema de Espacios Abiertos al conjunto integrado y continuo de espacios en general libres de edificación, de interés medioambiental, cultural, visual, recreativo y las conexiones ecológicas y funcionales que los relacionan entre sí, el cual tiene por objeto proveer de áreas recreativas al aire libre, proteger áreas y hábitat naturales así como el patrón ecológico del lugar y los valores culturales y paisajísticos, mejorar el paisaje visual y preservar zonas de transición físicas y visuales entre distintos usos y actividades, e incluirán los siguientes paisajes:

- Los elementos incluidos en el Catalogo de Paisaje

- Las conexiones ecológicas y funcionales o franjas de terreno que conectan los espacios del apartado anterior y que aun no teniendo elementos de singularidad manifiesta paisajística o incluso se encuentren degradados, se consideran necesarios como áreas de conexión entre los espacios de interés para lograr una continuidad física, ecológica y funcional. En cualquier caso, incluirá la red hídrica, senderos históricos, vías pecuarias, infraestructuras y similares y los corredores verdes que desempeñan funciones de conexión biológica y territorial.

Queda de manifiesto el potencial que tiene "La Sabana", donde, desde la ecología de paisaje estaría cumpliendo la función como un sistema que permite los flujos de agua y la importancia de mantener la vegetación original como bosque (en este caso selva) de galería; desde el punto de vista del urbanismo ecológico, bioclimático o sustentable, como una oportunidad para estructurar y ordenar el territorio y el desarrollo urbano: accesible, incluyente, seguro, estético, lugar de encuentro social y cultural asociado a su medio natural; desde la perspectiva de infraestructura verde, también su funcionamiento a escala territorial vinculado con la estructura urbana y el sistema de áreas verdes y espacios públicos; por su parte la precepción social que se tiene sobre el humedal permitirá establecer la relación entre la población y su paisaje cultural. Todos aportan

\footnotetext{
${ }^{14}$ Reglamento de Paisaje de Comunidad Valenciana Decreto 120/2006, de 11 agosto. Disponible en línea: <http://portal.uc3m.es/portal/page/portal/inst_pascual_madoz/Bases_de_Datos/legislacion/Decreto120_06_CVAL.pdf $>$
} 
elementos clave que serán considerados en el análisis del lugar, el diagnóstico integrado y en el planteamiento del Plan Maestro Urbano Paisajístico de "La Sabana".

\subsubsection{Humedales y la Convención Relativa a los Humedales de Importancia Internacional (RAMSAR) \\ Concepto de humedales y clasificación}

Humedales de agua dulce, se definen como cualquier área cubierta por agua dulce poco profunda, por lo menos durante una parte del ciclo anual; en consecuencia, los suelos de los humedales están saturados con agua, de manera continua o esporádica. El factor clave que determina la productividad y composición de especies en la comunidad del humedal es el hidro periodo, es decir, la periodicidad de las fluctuaciones del nivel del agua. Los humedales de agua dulce pueden, por tanto, clasificarse como "ecosistemas de nivel de agua fluctuante estabilizada en pulsaciones", igual que los ecosistemas marinos de zonas de mareas y estuarios (P. Odum \& W. Barrett, 2006).

Los humedales tienden a ser sistemas abiertos, que se clasifican convenientemente según sus conexiones con ecosistemas de agua profunda o tierra arriba, o con ambos, como se muestra a continuación:

- Los humedales ribereños, están ubicados en depresiones poco profundas y planicies aluviales asociadas con los ríos;

- Los humedales lacustres (de lacus, "lago") se asocian con lagos, estanques o canales de ríos con represas. Se inundan periódicamente cuando sus cuerpos más profundos de agua rebosan;

- Los humedales palustres (de palus "pantano") incluyen lo que se conoce por diversos nombres como: ciénegas, lodazales, fangales, praderas húmedas y estanques temporales que aparecen en depresiones que no están conectadas directamente con lagos o ríos (aunque pueden estar en antiguos lechos de ríos, estanques o cuencas de lagos rellenas) (P. Odum \& W. Barrett, 2006, p. 428). 
De acuerdo a la descripción anterior, por las características dadas, "La Sabana" se circunscribe en el concepto de humedal palustre.

\section{Convención relativa a los humedales de importancia internacional, especialmente como hábitat de aves acuáticas (Ramsar) (1971).}

La convención relativa a los humedales de importancia internacional, especialmente como hábitat de aves acuáticas suscrita en Ramsar, el 2 de febrero de 1971, reconoce en su preámbulo la interdependencia del hombre y de su medio ambiente, considerando las funciones ecológicas fundamentales de los humedales en su calidad de reguladores de los regímenes hidrológicos, y por tanto, son hábitat de una fauna y flora características, y particularmente, de las aves acuáticas. Reconoce que los humedales constituyen un recurso de gran valor económico, cultural, científico y recreativo, cuya pérdida sería irreparable. La convención reconoce el valor estético y paisajístico que poseen los humedales y la importancia de su protección, por tratarse de ecosistemas sumamente frágiles ${ }^{15}$.

De acuerdo al Manual de la Convención de Ramsar (2006, 4a․ Edición), los humedales son zonas donde el agua es el principal factor controlador del medio y la vida vegetal y animal asociada a él. Los humedales se dan donde la capa freática se halla en la superficie terrestre o cerca de ella o donde la tierra está cubierta por aguas poco profundas. Por su parte dicha Convención señala en su artículo 1, que se entiende por humedales "las extensiones de marismas, pantanos y turberas, o superficies cubiertas de aguas, sean éstas de régimen natural o artificial, permanentes o temporales, estancadas o corrientes, dulces, salobres o saladas, incluidas las extensiones de agua marina cuya profundidad en marea baja no exceda de seis metros". Además, a efectos de proteger sitios coherentes, el Artículo 2.1 estipula que los humedales que se incluirán en la Lista de Ramsar de Humedales de Importancia Internacional "podrán comprender sus zonas ribereñas o costeras adyacentes, así como las islas o extensiones de agua marina

\footnotetext{
${ }^{15}$ Convención relativa a los Humedales de Importancia Internacional (Ramsar) (1971):

http://www.ramsar.org/key_conv_e.htm
} 
de una profundidad superior a los seis metros en marea baja, cuando se encuentren dentro del humedal" (Manual de la Convención de Ramsar, 2006).

En general, se reconocen cinco tipos de humedales principales:

- Marinos (humedales costeros, inclusive lagunas costeras, costas rocosas y arrecifes de coral);

- Estuarinos (incluidos deltas, marismas de marea y manglares);

- Lacustres (humedales asociados con lagos);

- Ribereños (humedales adyacentes a ríos y arroyos); y

- Palustres (es decir, "pantanosos" - marismas, pantanos y ciénagas) (Manual de la Convención de Ramsar, 2006).

\section{Funciones}

Las interacciones de los componentes físicos, biológicos y químicos de un humedal, como los suelos, el agua, las plantas y los animales, hacen posible que desempeñe muchas funciones vitales, como por ejemplo: almacenamiento de agua; protección contra tormentas y mitigación de crecidas; estabilización de costas y control de la erosión; recarga de acuíferos (movimiento descendente de agua del humedal al acuífero subterráneo); descarga de acuíferos (movimiento ascendente de aguas que se convierten en aguas superficiales en un humedal); depuración de aguas; retención de nutrientes; retención de sedimentos; retención de contaminantes; estabilización de las condiciones climáticas locales, particularmente lluvia y temperatura (Manual de la Convención de Ramsar, 2006).

\section{Valores}

Los humedales reportan beneficios económicos enormes, como por ejemplo: abastecimiento de agua (cantidad y calidad); pesca (más de dos tercios de las capturas mundiales de peces están vinculadas a la salud de las zonas de humedales); agricultura, 
gracias al mantenimiento de las capas freáticas y a la retención de nutrientes en las llanuras aluviales; madera y otros materiales de construcción; recursos energéticos, como turba y materia vegetal; recursos de vida silvestre; transporte; un amplio espectro de otros productos de humedales, incluidas hierbas medicinales; posibilidades de recreación y turismo (Manual de la Convención de Ramsar, 2006).

Además, los humedales poseen atributos especiales como parte del patrimonio cultural de la humanidad -están asociados a creencias religiosas y cosmológicas y a valores espirituales-, constituyen una fuente de inspiración estética y artística, aportan información arqueológica sobre el pasado remoto, sirven de refugios de vida silvestre y de base a importantes tradiciones sociales, económicas y culturales locales (Manual de la Convención de Ramsar, 2006).

\section{Servicios ambientales}

Los servicios ambientales son los beneficios que la gente recibe de los diferentes ecosistemas como selvas, humedales, bosques, desiertos, entre otros hábitats, ya sea de manera natural o por medio de su manejo sustentable, ya sea en el ámbito local, regional o global ${ }^{16}$.

Los humedales proveen beneficios significativos tanto para los seres humanos como para el buen funcionamiento de los procesos ecológicos del ecosistema. Entre los servicios que estos ambientes proporcionan se encuentran la conservación de la biodiversidad, el mantenimiento de germoplasma (material genético que se transmite a la descendencia), la estabilidad climática, la conservación de ciclos biológicos, suministro de áreas de refugio y zonas de crianza para una gran diversidad de especies, muchas de ellas de interés económico para el ser humano y el valor derivado de su belleza y significado cultural (Sanjurjo E., 2001) ${ }^{17}$.

\footnotetext{
${ }^{16}$ Fuente de ref: http://www.teorema.com.mx/biodiversidad/ecosistemas/los-servicios-ambientales/fecha de consulta 20 de agosto de 2021.

${ }^{17} \mathrm{En}$ : http://ramsar.conanp.gob.mx/servicio ambientales y amenazas.php, fecha de consulta 14 de marzo de 2017.
} 
Tal como se ha referido, la zona de la "La Sabana" es un paisaje cultural ubicado en la periferia de la ciudad, que en la actualidad podría considerarse desde lo excepcional; por su belleza escénica e importancia ecológica; hasta lo cotidiano, por la imagen urbana circundante; y degradado por las condiciones de contaminación y la presión urbana que enfrenta.

En este sentido se percibe a "La Sabana" como un paisaje cultural evolutivo, capaz de integrarse a la dinámica social, urbana, económica, ambiental y paisajística de la ciudad de Chetumal.

El humedal "La Sabana" tiene un gran potencial de formar parte del desarrollo de la ciudad como elemento articulador de la estructura urbana, integrador de diversos elementos de equipamiento urbano, regulador ambiental, espacio de adaptación, mitigador y resiliente ante el cambio climático, aglutinador de actividades sociales, recreativas, culturales, administrativas, económicas y paisajísticas.

En concordancia con lo anterior, es importante analizar el funcionamiento natural del humedal para definir el polígono de actuación sobre el conocimiento de sus áreas de inundación y con mejores condiciones para el desarrollo de infraestructura; analizar la estructura urbana en su conjunto, para determinar la mejor propuesta de continuidad vial y fomentar con ello la movilidad y accesibilidad. Por otro lado, también deben estudiarse los aspectos urbanos circundantes para la mejora de la imagen urbana, así como de la determinación de equipamientos necesarios a una escala barrial y urbana, y determinar las localizaciones de estos equipamientos.

De la misma forma debe contemplarse la movilidad sostenible, mediante la consideración de ciclo vías y senderos peatonales; espacios abiertos como parques, jardines, plazas o plazuelas, cuyas características formales y funcionales fomenten las actividades de integración, convivencia y congregación social. Paralelamente deben considerarse espacios habilitados para incentivar el comercio y la productividad local, compatibles con la vivienda, el recreo y la educación para generar una multiplicidad de actividades en todo momento, generando un nodo de actividad social, urbana y económica, que otorgue 
mayor plusvalía al sitio y reafirme los valores intrínsecos de "La Sabana" y sus alrededores.

\section{MARCO METODOLÓGICO}

\section{Objetivos}

\section{General}

Elaborar un Plan Maestro Urbano Paisajístico para el Humedal "La Sabana", que determine las estrategias, políticas y acciones, que permitan integrar armónicamente el humedal al desarrollo de la ciudad, a fin de potenciar su uso compatible con las actividades urbanas y mejorar su estado de conservación, para incrementar los beneficios que aporta al bienestar de la población.

\section{Específicos}

Analizar los elementos básicos que conforman el humedal "La Sabana" y su entorno urbano, para comprender sus características, funcionamiento y sus interrelaciones.

Identificar las problemáticas, limitantes y potencialidades, asociadas al humedal "La Sabana" y su entorno urbano, que permita reconocer y plantear los escenarios posibles hacia el futuro.

Establecer los lineamientos de diseño paisajístico y urbano para el humedal "La Sabana" más adecuados, para su protección, aprovechamiento y desarrollo de la ciudad, en concordancia con la imagen objetivo y al futuro al que se desea llegar.

Desarrollar una propuesta de diseño conceptual, previendo la introducción de los servicios básicos, infraestructura y equipamiento, así como factores de accesibilidad y movilidad, que permita integrar y mejorar el desarrollo urbano y social de la ciudad de Chetumal, rescatando las cualidades paisajísticas y escénicas del lugar, que permita potenciar los valores ambientales y culturales de "La Sabana". 


\section{Hipótesis o supuestos}

El estudio y comprensión del funcionamiento natural del humedal, de sus cualidades paisajísticas y del entorno urbano, bajo las diferentes perspectivas de intervención: ecológica, paisajística y urbana, permitirán establecer los lineamientos de diseño urbano, paisajístico y ambiental articulados en un Plan Maestro, para el aprovechamiento, puesta en valor, salvaguarda y conservación del humedal "La Sabana".

\section{Preguntas de investigación}

Las preguntas que orientan el trabajo de investigación se estructuran en campos temáticos referentes a la teoría y el método; el crecimiento urbano y su impacto sobre el humedal; instrumentos normativos y regulatorios; y finalmente la integración paisajística y urbana del humedal.

\section{A. La teoría y el método}

¿Cómo abordar el estudio del humedal "La Sabana"? qué parámetros son necesarios para comprender su funcionamiento natural, ecológico, así como sus funciones urbanas y paisajísticas del lugar.

\section{B. El crecimiento urbano y su impacto sobre el humedal}

¿Cuál es la relación de la ciudad con el humedal, qué impactos se han generado en el lugar y cuál es la precepción de la ciudadanía con su paisaje?

\section{F. Instrumentos normativos y regulatorios}

¿Qué regulaciones existen sobre sobre el humedal, para su cuidado y protección, y cuáles son las directrices del desarrollo urbano?

\section{H. La integración Paisajística y urbana}

¿Cómo se puede coadyuvar al crecimiento urbano, en cuanto a conectividad y movilidad, y qué elementos permitirán una mayor integración de uso con respecto del humedal y las actividades urbanas? 


\section{Metodología}

Para abordar el humedal "La Sabana" y su relación con el ámbito urbano y paisajístico, se recurrirá a la técnica de investigación documental y de campo, utilizando el método de investigación cualitativo, que permita describir y comprender el fenómeno en estudio.Se parte de la premisa que para conocer el funcionamiento integral de "La Sabana" se deberá abordar desde las perspectivas natural, urbana, social y paisajística, así como las relaciones existentes entre estas esferas; para ello, el apartado técnico de la investigación se estructura en: Caracterización del sitio, Diagnóstico Integrado, y Lineamientos ambientales, urbanos, paisajísticos y sociales. En cada una de estas etapas sucesivas, se aborda lo natural como marco biogeofísico del desenvolviendo social, la fenomenología de lo urbano como un conjunto complejo de procesos que dan lugar a la apropiación territorial de un espacio dado para la construcción y desarrollo de las aglomeraciones urbanas; y lo social como todos aquellos aspectos en los que interactúa el hombre y sus efectos en las formas de apropiación y aprovechamiento del espacio natural y urbano. Al mismo tiempo, se analizan las relaciones entre estos, y se revisan otras variables como los aspectos identitarios y perceptivos del paisaje.

De manera particular, el estudio del entorno físico natural del humedal "La Sabana", además de definir sus características generales, pretende reconocer la asociación entre el cuerpo de agua, la vegetación, el uso de suelo, la edafología y la topografía, con el objeto de definir una delimitación lacustre y su zona ribereña. Cada una de estas características se presentan en diferentes capas de información cartográfica del INEGI, las cuales una vez sobrepuestas permite identificar coincidencias o divergencias espaciales y a partir de esto, se puede determinar una relación entre estos rasgos geográficos. Para efectos prácticos, este análisis se realizará utilizando herramientas tecnológicas de sistemas de información geográfica (SIG), con el software Arc Map versión 10.2 .

El análisis del crecimiento histórico de la ciudad de Chetumal y sus implicaciones en el grado de conservación y preservación del Humedal La Sabana, se realizará mediante la 
comparación de cartografía que revele el crecimiento histórico del área urbana de la ciudad en diferentes periodos de tiempo. El objeto de esta revisión y análisis es identificar la transformación que ha sufrido la estructura urbana de Chetumal, las principales tendencias de expansión urbana, su morfología, la dosificación de los usos de suelo, la configuración de las redes de infraestructura, la localización de los principales elementos de equipamiento urbano, las zonas cubiertas por los servicios públicos, las características básicas de la vivienda y la ubicación de parques y áreas verdes urbanas; así como de los asentamientos irregulares identificados a la fecha. Para validar la información derivada de los estudios fotogramétricos y del análisis de las imágenes satelitales o documentos cartográficos, se realizarán recorridos en campo.

Con respecto de la percepción del entorno urbano-arquitectónico y paisajístico, conviene precisar que el paisaje se constituye tanto por los aspectos físicos que lo componen como por la forma en que estos son percibidos; por ello es importante incluir la imagen urbana arquitectónica del lugar; así como sus rasgos paisajísticos más relevantes; los cuales contribuirán a definir la relación de la población con el sitio con respecto de la apropiación, identidad y valoración del lugar. Para ello se recurrirá al estudio de fotografías históricas y actuales recolectadas en recorridos de campo, así como el levantamiento de encuestas y cuestionarios a diversos actores sociales e informantes que conocen o tienen alguna relación con "La Sabana", sea de interés personal, profesional, académico o como servidores públicos.

El análisis del entorno social por su parte incluye el estudio de aspectos sociodemográficos, económicos y culturales, a efecto de comprender la estructura social del sitio, los rasgos culturales de la población y el nivel de calidad de vida, utilizando información estadística oficial (INEGI, SEDESOL), la cual estará vinculada a la plataforma cartográfica creada en el sistema de información geográfica mencionado anteriormente.

La revisión de los aspectos jurídico legales permitirá visualizar las directrices normativas que se ciernen sobre el humedal y su zona de estudio. 
El análisis de los factores anteriormente señalados permitirá delinear el diagnostico integrado, el cual dará cuenta de una caracterización del sitio y permitirá identificar claramente sus limitaciones y potencialidades, en los ámbitos de lo ambiental, urbano y paisajístico. A partir de esto, se identificará la problemática general, misma que, una vez revisada, permitirá delinear un esquema prospectivo mediante la delineación de escenarios alternativos de solución, como base para la construcción de la imagen objetivo del proyecto.

Finalmente, en el capítulo de Lineamientos de diseño ambiental, urbano, paisajístico y social para el humedal "La Sabana", se presentan los criterios de intervención, que guían las acciones específicas para alcanzar los objetivos ambientales, urbanos, paisajísticos y sociales que dan sentido al Plan Maestro y que permiten desarrollar la propuesta conceptual y proyectual de integración urbana y paisajística. 


\section{CARACTERIZACIÓN DEL SITIO}

\subsection{MARCO BIOGEOFÍSICO DEL HUMEDAL "LA SABANA"}

\section{Localización geográfica ${ }^{18}$}

El humedal "La Sabana" se localiza al sur de la república mexicana, en el Estado de Quintana Roo, específicamente colindando con la ciudad de Chetumal.

\section{Figura 1. Área de referencia del humedal "La Sabana".}

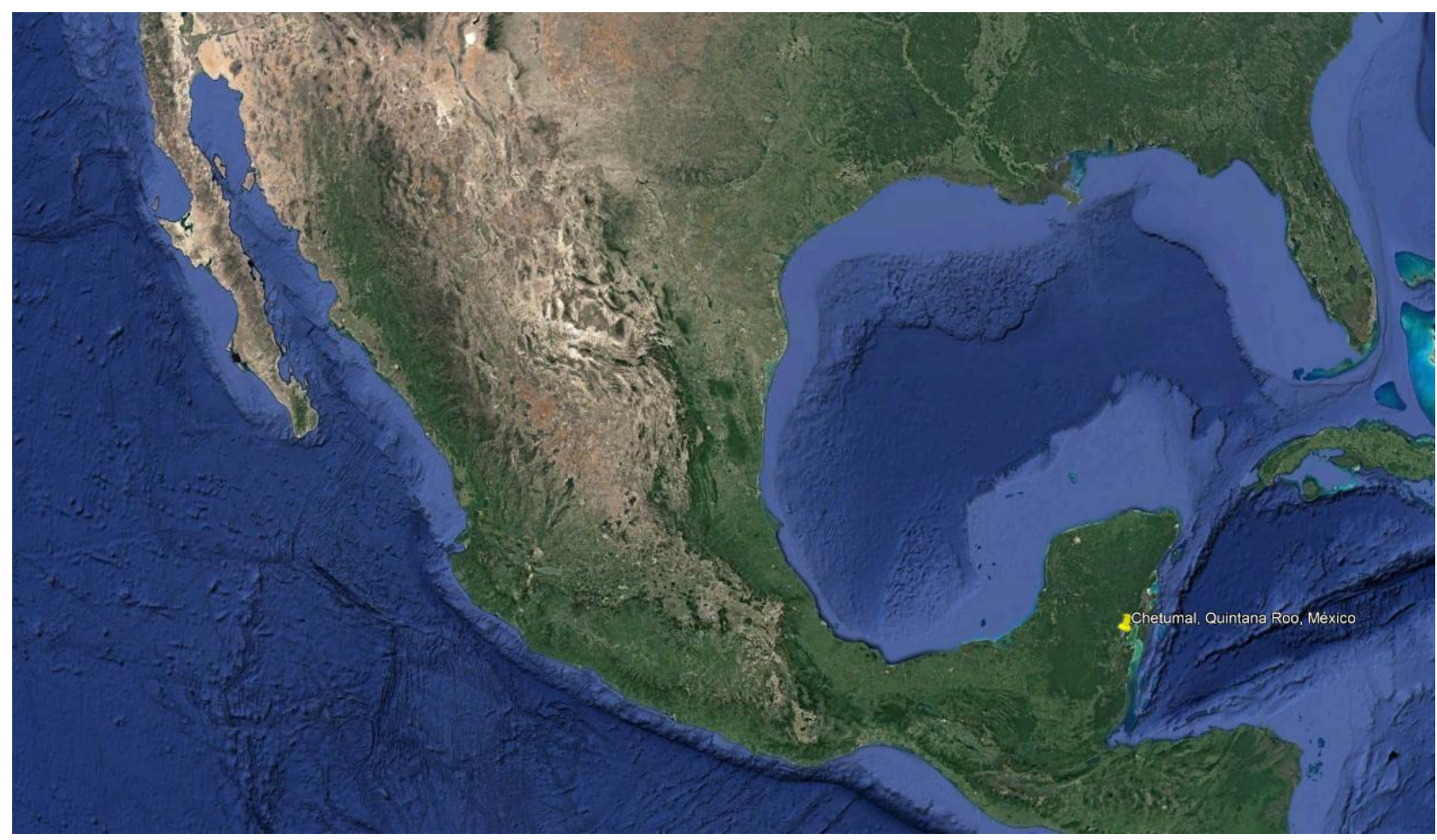

Fuente: Elaboración propia, con Google Earth Pro, fecha de consulta 20 de agosto de 2021.

En términos hidrográficos "La Sabana" se localiza en la subcuenca hidrográfica RH33Ac, Bahía de Chetumal, que forma parte de la Cuenca denominada Bahía de Chetumal y otras, de la Región Hidráulica Yucatán Este (RH 33 Yucatán Este) (PDU, 2018).

\footnotetext{
${ }^{18}$ De: Programa de Desarrollo Urbano de Chetumal, Calderitas, Subteniente López, Huay-Pix y Xul-Ha. Municipio de Othón P. Blanco", publicado el 27 de marzo de 2018 en el periódico oficial del Estado de Quintana Roo, en adelante: PDU, 2018.
} 
Esta subregión se enmarca geográficamente entre los $17^{\circ} 49^{\prime}$ y $20^{\circ} 12^{\prime}$ latitud norte y entre los $87^{\circ} 30^{\prime}$ y $89^{\circ} 27^{\prime}$ de longitud oeste. Colinda al poniente con las regiones hidrológicas 30 y 31 y al norte con la 32. Hacia el oriente limita con el Mar Caribe y por el sur por una línea definida por la Bahía de Chetumal, por el límite internacional de Belice en un tramo de límite natural constituido por el Río Hondo y por el límite político con Belice y Guatemala (PDU, 2018)."La Sabana” es un humedal de tipo palustre, asociado a la región hidrológica RH33 y dentro de esta a la cuenca "A" conocida como Bahía de Chetumal y otras, que se enmarca en los territorios político-administrativos de los municipios de Bacalar y Othón P. Blanco, y colinda con la Bahía de Chetumal, en el sur de Quintana Roo.Se localiza al noroeste de la Ciudad de Chetumal y colinda con el área urbana, fungiendo como límite natural del crecimiento urbano; tiene una extensión longitudinal aproximadamente de $6 \mathrm{~km}$-en lo que corresponde al cuerpo de agua; una anchura variable, pero en la parte más ancha de 398 metros, y una profundidad variable $(4 \mathrm{~m}$. en lo más profundo). La vegetación predominante es de tular. Es un elemento natural de gran valor ambiental y paisajístico, que cumple varias funciones y aporta servicios ambientales diversos, además de regulador del clima y de inundaciones (PDU, 2018).

En Othón P. Blanco se encuentran las únicas aguas superficiales ${ }^{19}$ de todo el territorio de Quintana Roo y la Península de Yucatán: el Río Hondo y el Río Escondido. El Río Hondo nace en las sierras fronterizas entre Belice y Guatemala y desemboca en la ciudad de Chetumal. El Río Escondido es una corriente proveniente de Campeche, es mayormente estacional y de cauce muy irregular, usualmente se une a amplias aguadas y desemboca en el río Hondo al sur de la Laguna de Bacalar (PDU, 2018).

En cuanto a cuerpos de agua lénticos ${ }^{20}$, el más conspicuo es la Laguna Milagros y se observan otros más cercanos a la localidad de Subteniente López (Laguna Orquídea y

\footnotetext{
${ }^{19}$ El resto de las corrientes superficiales, a excepción de los pequeños desagües naturales que se forman durante la temporada máxima de lluvias, mismos que por las características kársticas del suelo son rápidamente drenados hacia las capas inferiores.

${ }^{20}$ Los lagos, lagunas, estanques, humedales, pantanos y charcas, son aguas tranquilas que se clasifican como aguas lénticas, ya que no fluyen. Al no tener un flujo continuo de líquido, en las aguas lénticas tienden a formarse sedimentos en el fondo. Fuente: https://www.lifeder.com/aguas-lenticas/. Fecha de consulta 13 de Enero de 2021.
} 
Laguna Encantada). Se incluye también dentro del área, a la parte sur de la Laguna de Bacalar y al estero Chaac (inmediatamente al oeste de Huay-Pix) que comunica a ésta de manera intermitente con el Río Hondo (PDU, 2018).

Sin embargo el acercamiento de la zona urbana y la creciente actividad antropogénica en su entorno, han comenzado a generar cambios y modificaciones en el funcionamiento hidráulico de "La Sabana", particularmente lo referido a la construcción de pasos de caminos, que por ser soluciones sin ningún diseño ni planificación, en la realidad actúan como barreras o diques que obstruyen el flujo natural, por lo que en épocas de lluvias extraordinarias e intensas ya son evidentes los efectos de inundaciones en sus inmediaciones, tal como reportan distintos medios de comunicación ${ }^{21}$, afectando no solo las viviendas sino también la salud de la población ${ }^{22}$.

Para comprender el funcionamiento natural de este sistema, es necesario comenzar abordando la escala de análisis de la ecología del paisaje basada en cuencas o subcuencas hidrológicas, para obtener un panorama más completo de los elementos naturales que conforman el territorio y su articulación entre ellos y entre los paisajes culturales determinados por la intervención del hombre. Esto supone un mejor acercamiento al objeto de estudio lo que posteriormente permitirá tomar decisiones e implementar una serie de actuaciones sobre el paisaje más certero, lógico y cercano a la realidad territorial y paisajística, que tendría que considerar la propuesta de expertos y especialistas, y los intereses de la sociedad en su conjunto, de tal forma que representa el primer acercamiento al estudio del paisaje y el territorio; con base en ello se pueden definir escalas más específicas con objetivos también más particulares.

\footnotetext{
${ }^{21} \mathrm{https} / / /$ www.expedientequintanaroo.com/2012/08/setenta-por-ciento-de-chetumal-no-tiene.html [ref. de 2013 de enero de 2021]

${ }^{22}$ https://sipse.com/novedades/menores-vulnerables-a-enfermedades-en-chetumal-52428.html [ref. de 2013 de enero de 2021]
} 


\subsubsection{Región Hidrográfica}

La referencia territorial de la zona de estudio se estableció con respecto de una subcuenca hidrográfica, que de acuerdo a José Fariña ${ }^{23}$, permiten entender la escala del paisaje, lo que supone un buen criterio para fijar los límites de una zona de estudio, lo cual permite definir la escala del análisis territorial. Para ello visualizó en un SIG, la información cartográfica del INEGI, 2010 relativa a la Red hidrográfica RH33Ac, Bahía de Chetumal a una escala 1:1'000,000 y 1:150,000; lo que facilita, por un lado apreciar la subcuenca y vislumbrar a grandes rasgos el funcionamiento general de los humedales en su conjunto, y por otro lado, definir los contornos de los elementos de paisaje determinadas posteriormente, en un área más específica y cercana a la ciudad de Chetumal.

Figura 2. Zona de estudio, subcuenca hidrográfica RH33Ac, Bahía de Chetumal.

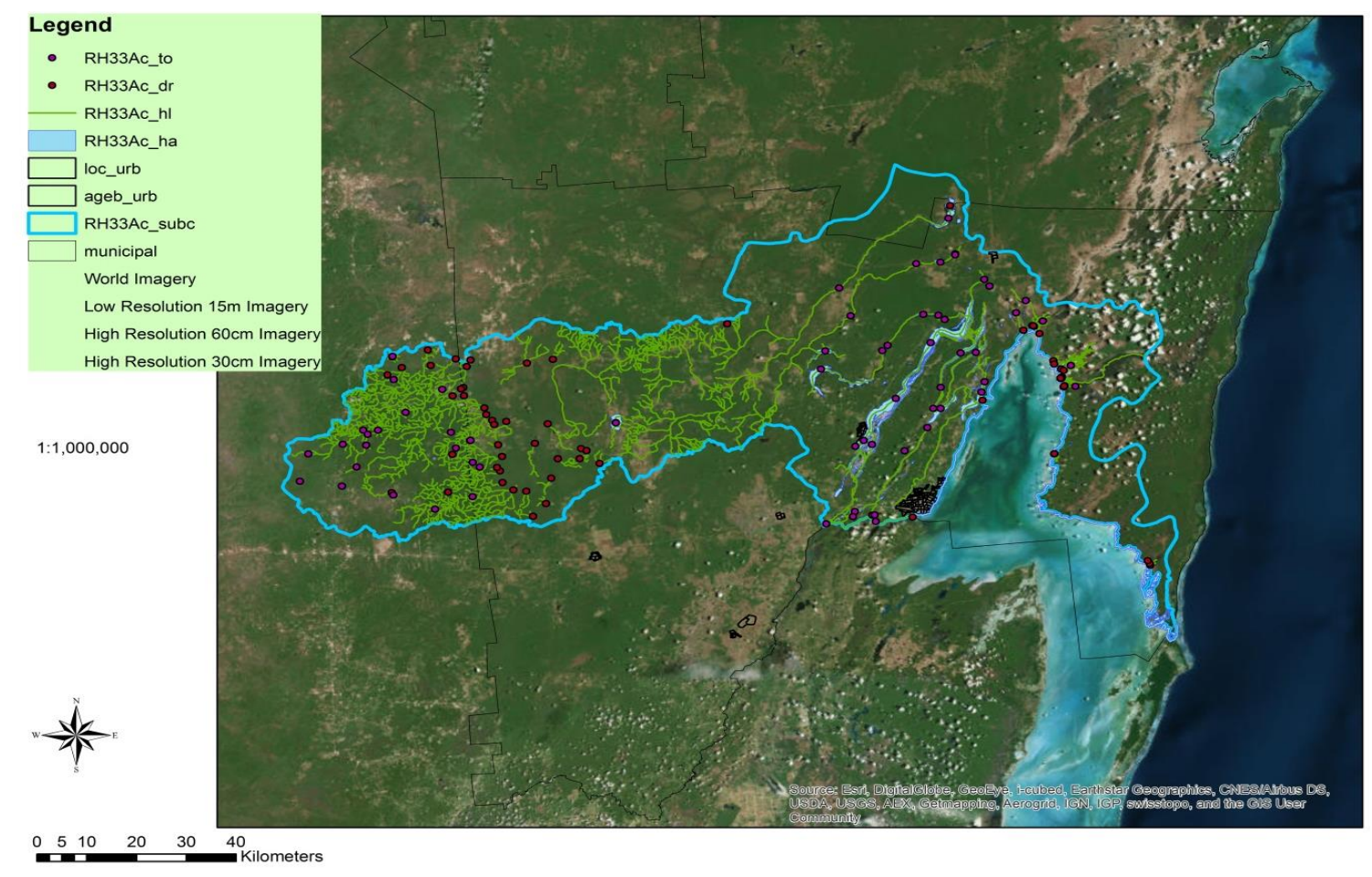

Fuente: Elaboración propia con datos del INEGI 2010, Red hidrográfica RH33Ac, Bahía de Chetumal, escala 1:50,000

${ }^{23}$ Fariña, José [en línea]. Infraestructura Verde. El Blog de José Fariña. Urbanismo, Territorio y Paisaje [ref. de 20 de julio de 2016] disponible en: < https://elblogdefarina.blogspot.mx/2011/07/infraestructuraverde.html > 
Para obtener estos resultados se utilizó información del Instituto Nacional de Estadística y Geografía (INEGI), específicamente con datos vectoriales de la red hidrográfica a escala 1:50,000. En ella se despliega información relativa a la subcuenca hidrográfica, que de acuerdo a dicho instituto (INEGI, 2010) ${ }^{24}$, se define como el área considerada como una subdivisión de la cuenca hidrográfica que presenta características particulares de escurrimiento y extensión. Su clave es el resultado de la concatenación de la clave de la región hidrográfica, más la clave de la cuenca y una letra minúscula de la "a" a la "z", en este caso "RH33Ac".

En la figura 3, puede observarse el cuerpo de agua permanente "La Sabana", al poniente del área urbana de la ciudad de Chetumal, mientras que en línea verde se señala el flujo superficial del agua asociado a la longitud total del humedal que desemboca en la Bahía de Chetumal, esto demarca la importancia como dren natural que aporta beneficios y servicios ambientales a la ciudad.

Figura 3. Zona de estudio, Ciudad de Chetumal, cuerpos de agua, humedales y flujos superficiales de agua, Escala 1:200,000.

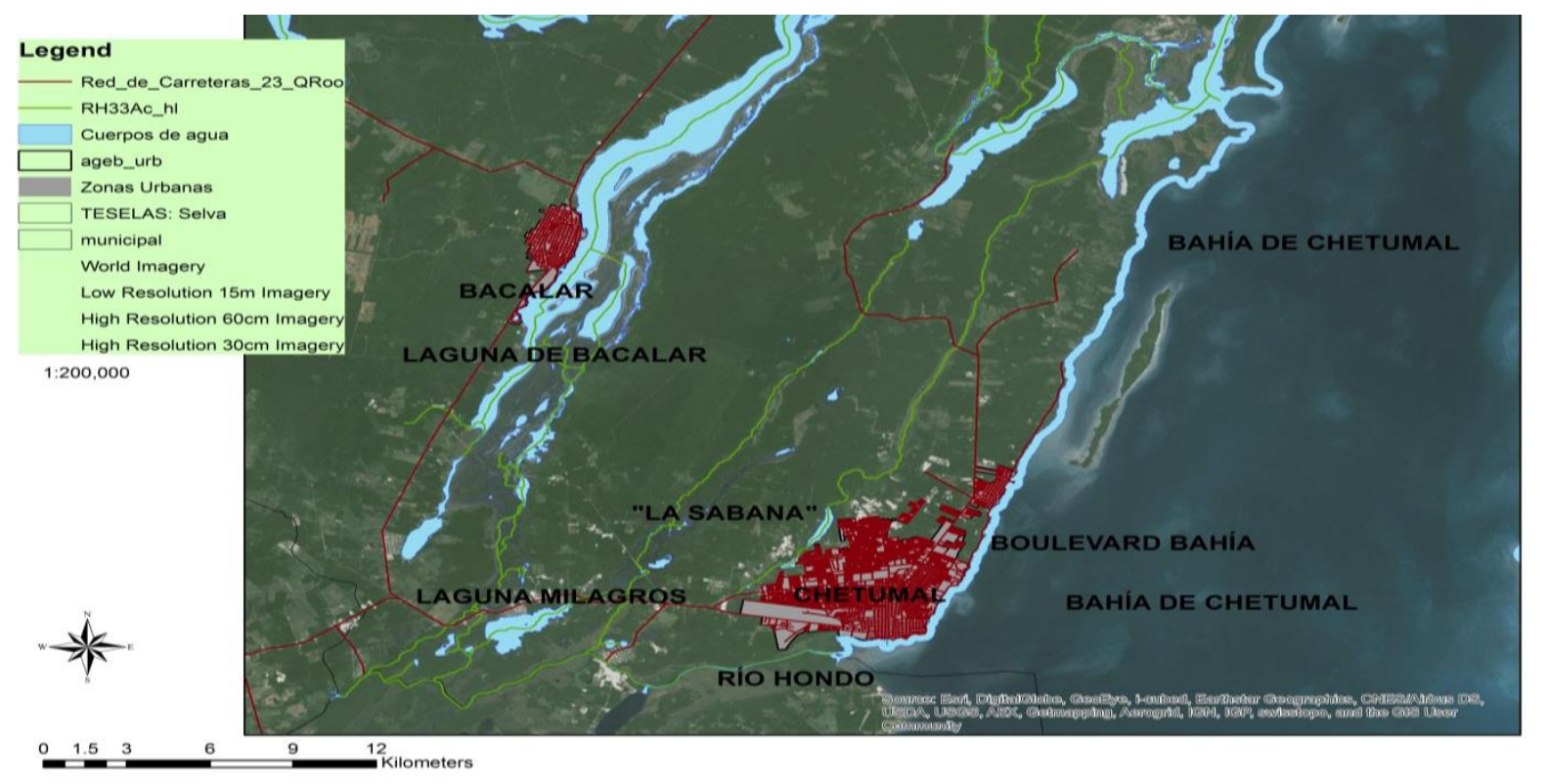

Fuente: Elaboración propia con datos del INEGI 2010, Red hidrográfica RH33Ac, Bahía de Chetumal, escala 1:50,000. Programa ArcGis 10.2. Nota: para efecto de la Red Hidrográfica las líneas (RH33Ac_hl) se usan para describir total o parcialmente la geometría de un flujo superficial de agua en dos dimensiones, el sentido del trazo de cada línea denota el comportamiento hidrológico de los escurrimientos.

24 INEGI, 2010. Documento técnico descriptivo de la red hidrográfica, escala 1:50 000. 


\subsubsection{Corredores de paisaje asociados a cuerpos de agua y humedales}

A esta escala de análisis conviene identificar los elementos del paisaje desde el punto de vista de la Ecología del Paisaje y en particular los corredores asociados a cuerpos de agua y humedales. Para ello se representó en un Sistema de Información Geográfica información hidrológica ${ }^{25}$, donde se muestran específicamente cuerpos de agua, la geometría de los flujos superficiales de agua (el sentido del trazo de cada línea denota el comportamiento hidrológico de los escurrimientos), así como los puntos de drenaje de la cuenca; la carta edafológica (Conjunto de Datos Vectorial Edafológico, Escala 1:250,000), donde se expresan los tipos de suelo, y en los cuales encontramos una asociación de los Gleysoles con los cuerpos de agua y humedales, y tipo de vegetación de tular en los cuerpos de agua, señalados en la carta de Usos de Suelo y Vegetación, escala 1:250, $000^{27}$.

Se sobrepusieron las capas de información de Suelos con los cuerpos de agua y humedales; sobre la geometría de los flujos superficiales de agua que forman parte de "La Sabana" prevalecen dos tipos de suelo ${ }^{28}$ : en lo que corresponde al área inmediata que bordea o forma parte del suelo del humedal (suelo de tipo Gleysol húmico Stágnico, de textura fina, que se refiere a suelos pantanosos o inundados a menos de $50 \mathrm{~cm}$ de profundidad la mayor parte del año, con alto contenido de materia orgánica en la capa superficial del suelo y con poco menos contenido de materia orgánica en las capas de abajo, representa suelos arcillosos de textura fina (con más de $35 \%$ de arcilla) que tienen mal drenaje, escasa porosidad, son por lo general duros al secarse, se inundan fácilmente y son menos favorables al laboreo (INEGI, 2004 y 1998). Por otra parte, en los suelos asociados a la línea de la geometría de los flujos superficiales de agua que forman parte del drenaje de "La Sabana" y su desembocadura con la Bahía de Chetumal, prevalecen

\footnotetext{
27 Conjunto de datos vectoriales de Uso del Suelo y Vegetación. Escala 1:250 000, Serie V (Capa Unión).

${ }^{28}$ Con Base en carta edafológica del INEGI, y Guía para la interpretación de Cartografía. Edafología.

INEGI, 2004. Y Base de datos geográficos. Diccionario de datos edafológicos escala 1:250,000 (vectorial), INEGI, 1998. Disponible en línea: < http://www.inegi.org.mx/geo/contenidos/recnat/edafologia/doc/dd edafologicos v1 250k.pdf> [ref. de consulta: 27 de marzo de 2017].
} 
los Gleysoles Vérticos Sódicos, Gleysol Hiposálico Vértico, y Leptosol Húmico Réndzico, de textura Media, lo que también corresponde a suelos pantanosos o inundados a menos de $50 \mathrm{~cm}$ de profundidad la mayor parte del año, con subsuelo ligeramente agrietado en alguna parte de la mayoría de los años, es un suelo con acumulación de sodio, suficiente para reducir su fertilidad y de textura media, comúnmente llamados francos, equilibrados generalmente en el contenido de arena, arcilla y limo (INEGI, 2004 y 1998). Mientras que el suelo en derredor que corresponde más a selvas, es Leptosol Calcárico Húmico, son suelos poco o nada atractivos para cultivos; presentan una potencialidad muy limitada para cultivos arbóreos o para pastos. Lo mejor es mantenerlos bajo bosque, es calcáreo entre 20 y $50 \mathrm{~cm}$ desde la superficie y con presencia de materia orgánica y nutrientes del $2 \%$ en los primeros $25 \mathrm{~cm}^{29}$.

Posteriormente se sobrepuso la capa de Usos de Suelo y Vegetación. Prácticamente hubo una coincidencia entre la cobertura vegetal tipo tular, con el tipo de suelo Gleysol asociado a los cuerpos de agua y el flujo superficial de "La Sabana", la consistencia de estos factores permite la constitución de corredores de paisaje que tienen al menos estos tres elementos coincidentes entre sí. Por su parte en la zona en la que el flujo superficial de "La Sabana" coincide con el suelo Leptosol Calcárico, la vegetación asociada correspondió a vegetación secundaria arbustiva de Selva mediana sub perennifolia, y en menor medida agricultura de temporal anual y pastizal cultivado.

Así mismo, donde parece perderse la continuidad o donde no es tan evidente la continuidad del corredor, las curvas de nivel aportadas por las cartas topográficas (escala 1:50,000) pueden ser contempladas como un criterio o factor de delimitación del contorno y la sección o secciones del corredor de paisaje asociado al humedal.

\footnotetext{
${ }^{29}$ Con base en: Base de datos geográficos. Diccionario de datos edafológicos escala 1:250,000 (vectorial), INEGI, 1998, y http://www.eweb.unex.es/eweb/edafo/FAO/Leptosol.htm
} 


\section{Figura 4. Corredor de paisaje asociado a "La Sabana", escala 1:150,000}

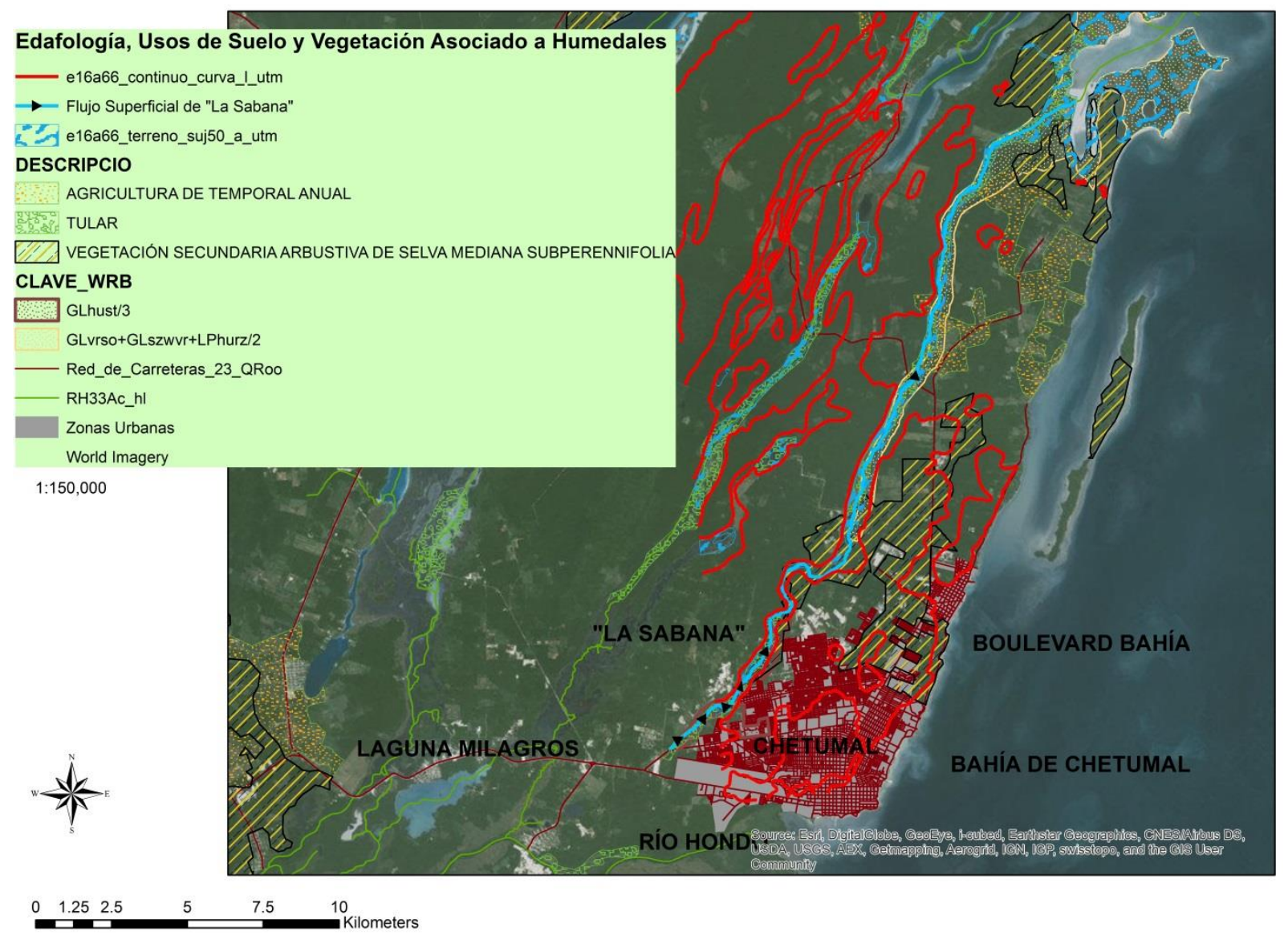

Fuente: Elaboración propia con datos del INEGI, 2010. Programa ArcGis 10.2.

El corredor de paisaje asociado a "La Sabana" se compone de dos elementos a destacar; por un lado los cuerpos de agua perennes, que conforman un límite físico o borde para el crecimiento de la ciudad, estos tienen una longitud de $6.13 \mathrm{~km}$, y una anchura máxima de 398 metros; y por otra parte la geometría superficial de los flujos del humedal hasta desembocar en la Bahía de Chetumal, la cual se da entre terrenos inundables pero sin el cuerpo de agua aparente, este tiene una longitud de $23.61 \mathrm{~km}$. Teniendo como longitud total del corredor $29.74 \mathrm{~km}$. 
Figura 5. Corredor de Paisaje "La Sabana", cuerpos de agua y zona urbana, escala $1: 50,000$

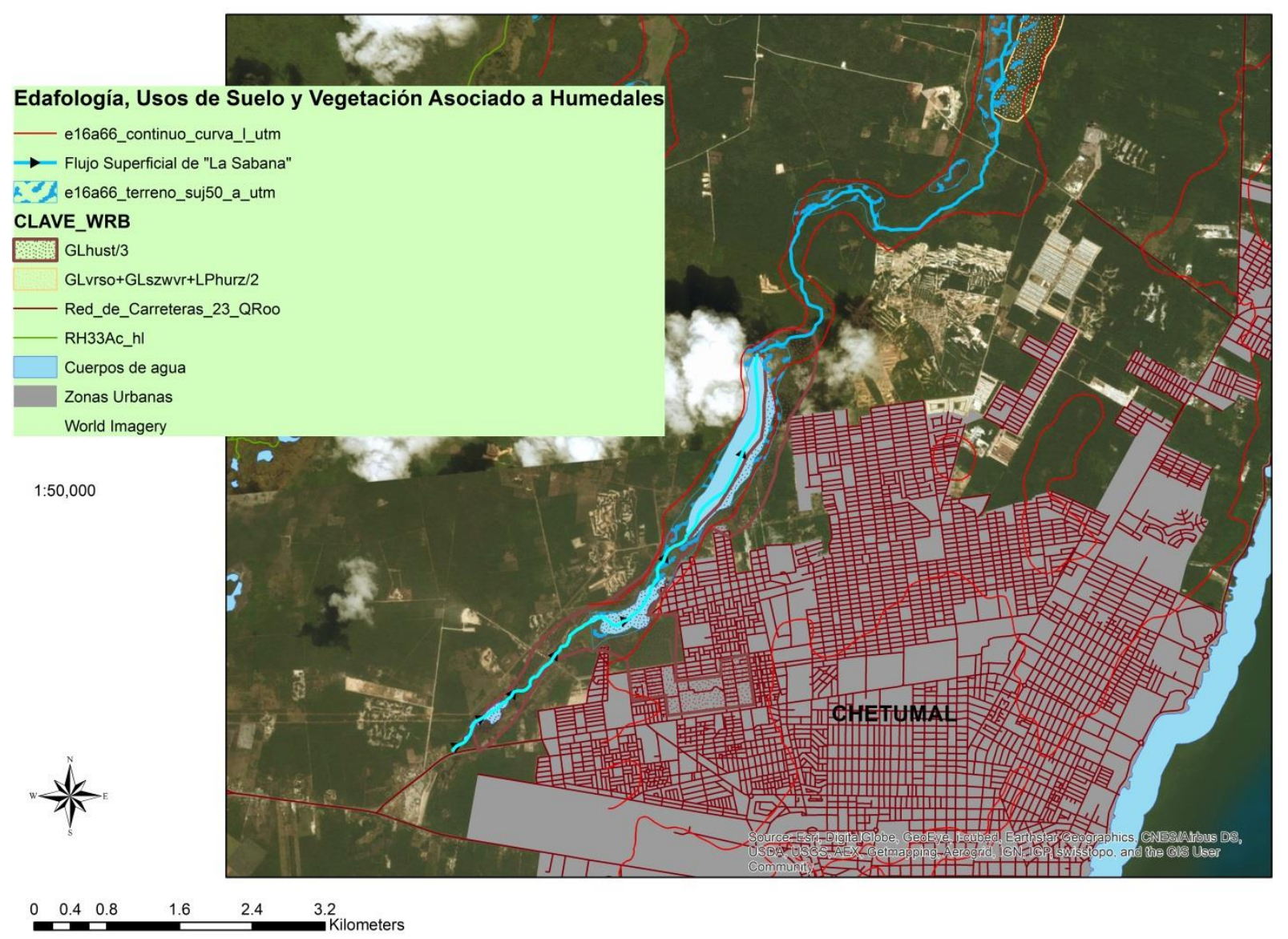

Fuente: Elaboración propia con datos del INEGI, 2010. Programa ArcGis 10.2.

\subsubsection{Vegetación predominante}

La vegetación asociada al humedal "La Sabana" es de tipo tular, la cual según INEGI ${ }^{30}$ (2005) está distribuida principalmente en altiplanicies y llanuras costeras, en sitios con climas desde cálidos hasta templados, con amplios rangos de temperatura, precipitación y altitud. Se desarrolla en lagunas y lagos de agua dulce o salada y de escasa profundidad, así como en áreas pantanosas, canales y remansos de ríos. Las plantas de esta comunidad viven arraigadas en el fondo y constituyen masas densas con hojas

\footnotetext{
${ }^{30}$ Guía para la interpretación de cartografía. Uso del suelo y vegetación. Escala 1:250,000 Serie V.
} 
largas y angostas, formando prácticamente un solo estrato herbáceo de $80 \mathrm{~cm}$ hasta 2.5 $\mathrm{m}$ de altura. Este tipo de vegetación está constituido básicamente por plantas de tule (Typha spp.), y tulillo (Scirpus spp.), pero también incluye los llamados carrizales de Phragmites communis y Arundo donax ${ }^{31}$ y los "saibadales" de Cladium jamaicense del sureste del país.

Tabla 1. Mosaico fotográfico de vegetación representativa asociada al humedal "La Sabana"

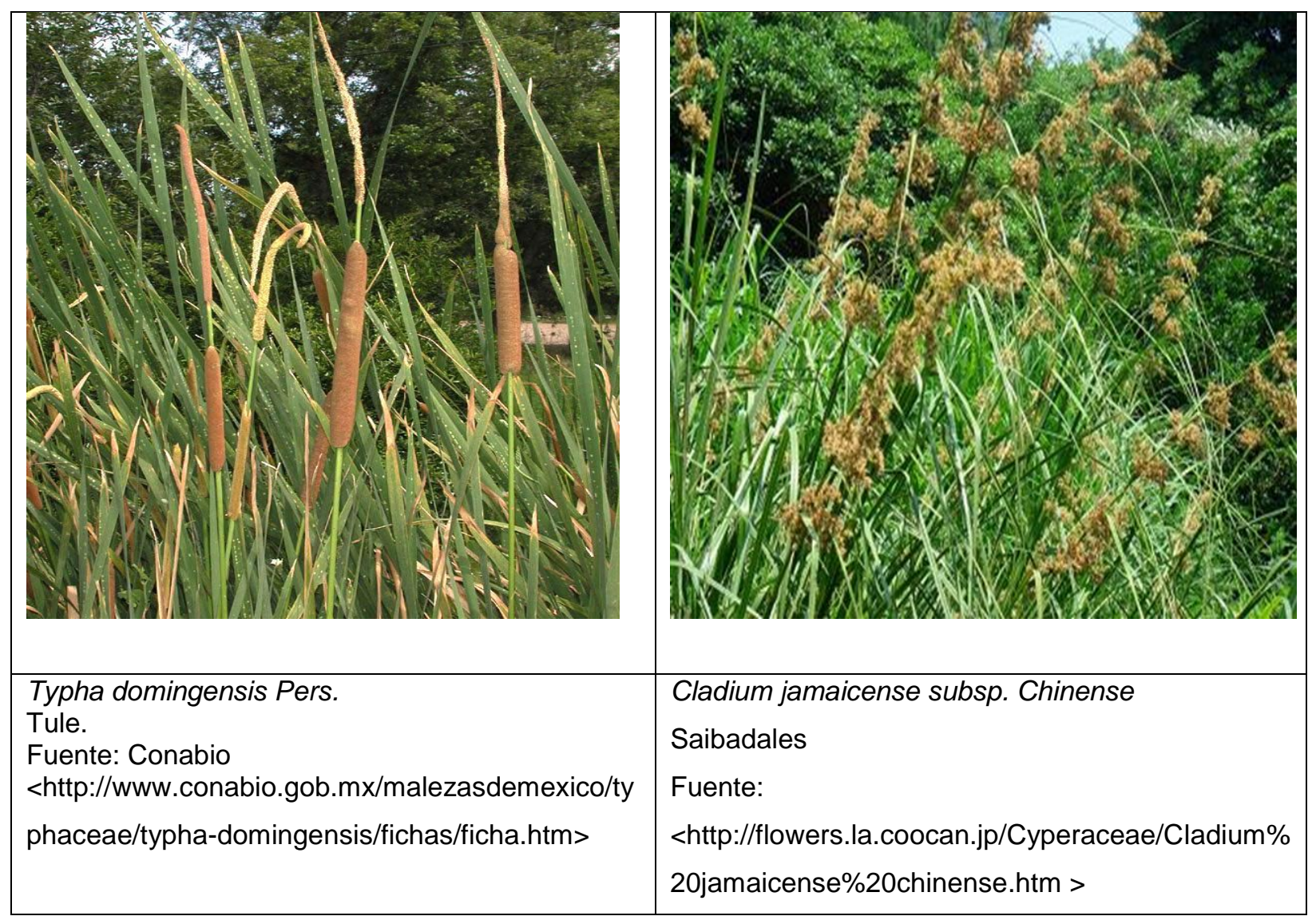

A efecto de identificar la vegetación específica del sitio, se tomó como referencia el levantamiento fotográfico correspondiente a una visita de campo con asesores y expertos en materia de arquitectura de paisaje, y desarrollo urbano sustentable.

\footnotetext{
${ }^{31}$ Ambas consideradas especies invasivas ver:

<http://www.conabio.gob.mx/institucion/proyectos/resultados/InfGN038.pdf>
} 
En esta secuencia fotográfica puede observarse que existe gran coincidencia con la vegetación predominante definida por el INEGI, sin embargo, se puede agregar a la lista anterior, especies de Mangle (Mangle botoncillo, Conocarpus erectus), además de especies de Nymphaea sp. (tabla 2).

Tabla 2. Mosaico fotográfico, visita de campo 2015

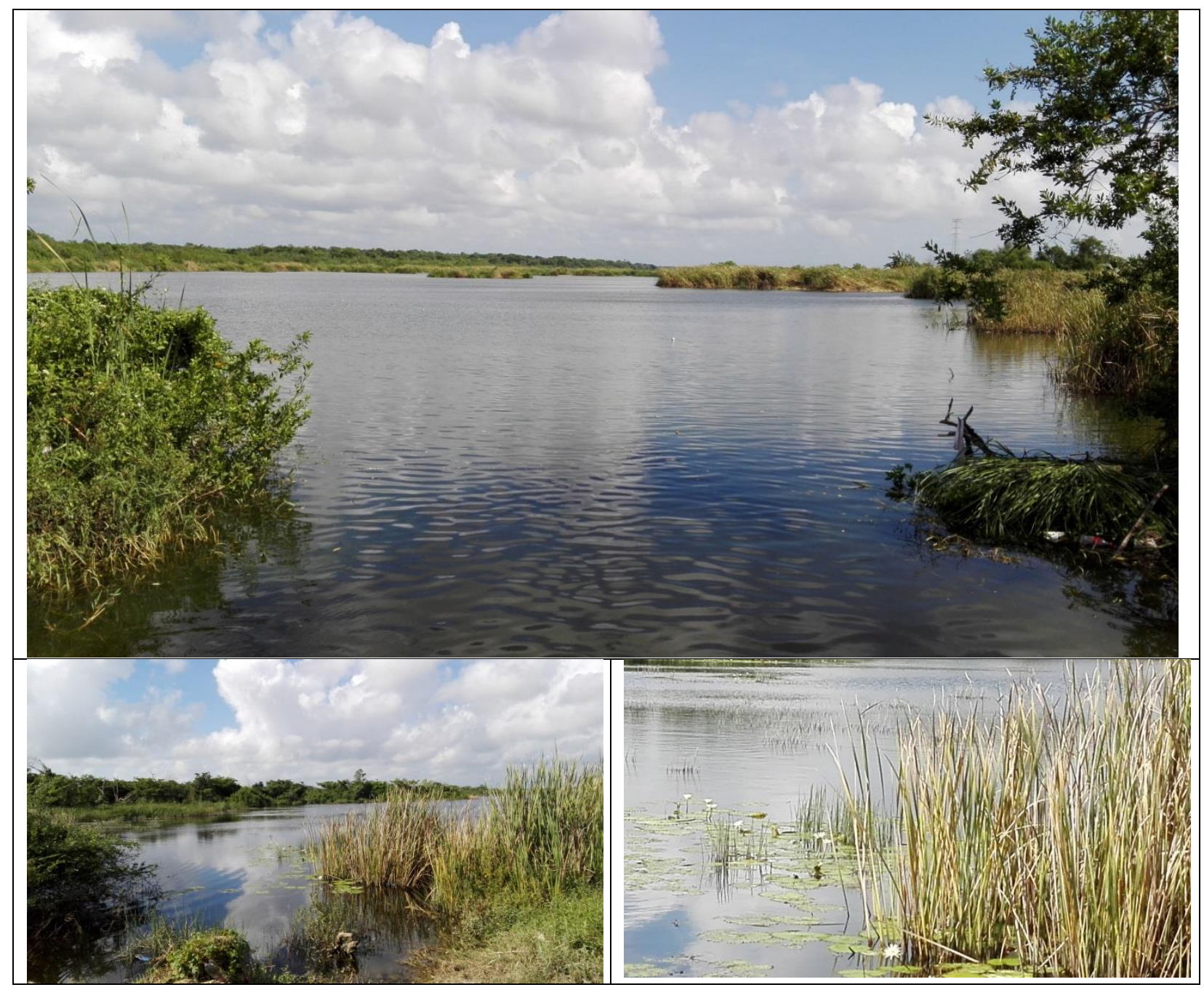




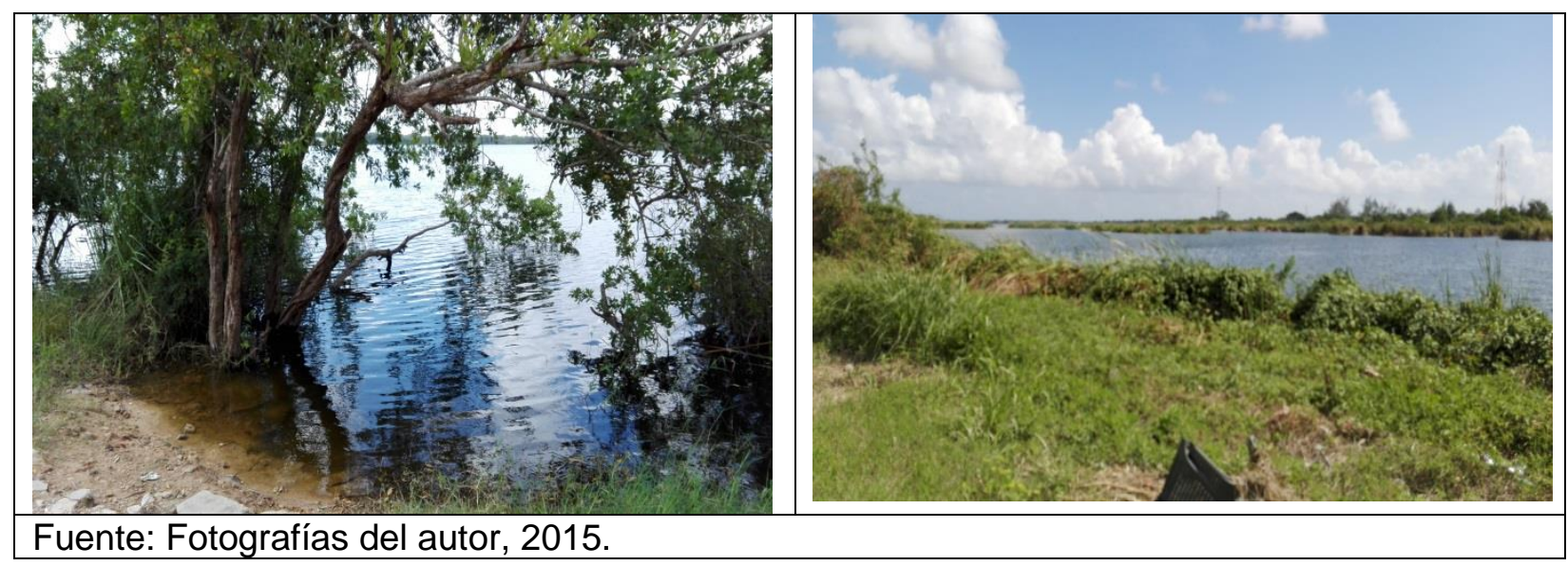

\subsubsection{Análisis Climático}

La temperatura de la Ciudad de Chetumal es cálido subhúmeda con lluvias en verano; se caracteriza por un ambiente caluroso y húmedo la mayor parte del año, con mañanas y noches frescas. En la figura 6, se observa el comportamiento de la temperatura mínima la cual oscila en promedio en los 20 y 25 grados centígrados; mientras que el promedio de la temperatura máxima está entre los 30 y $35^{\circ} \mathrm{C}$; sin embargo, en las horas más cálidas del día oscila entre los 35 y los $40^{\circ} \mathrm{C}$. Los meses más calurosos son de mayo a septiembre, y los más frescos de noviembre a febrero, pero principalmente diciembre y enero. 
Figura 6. Temperatura mínima Chetumal, 1952-2012

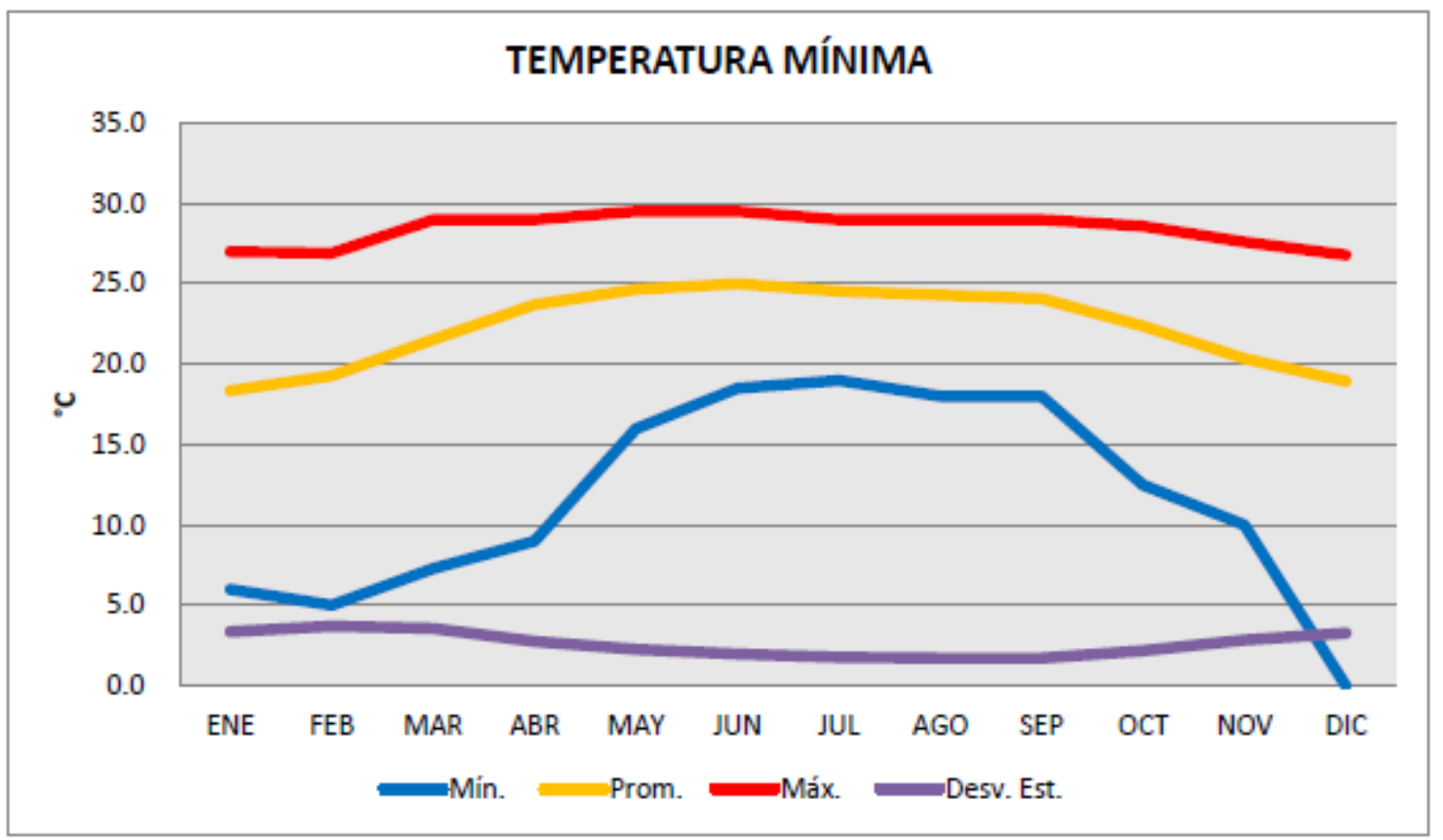

Fuente: CONAGUA, Servicio Meteorológico Nacional, Estaciones Climatológicas. Estación 23032, Chetumal (DGE).

\section{Figura 7.Temperatura máxima Chetumal, 1952-2012}

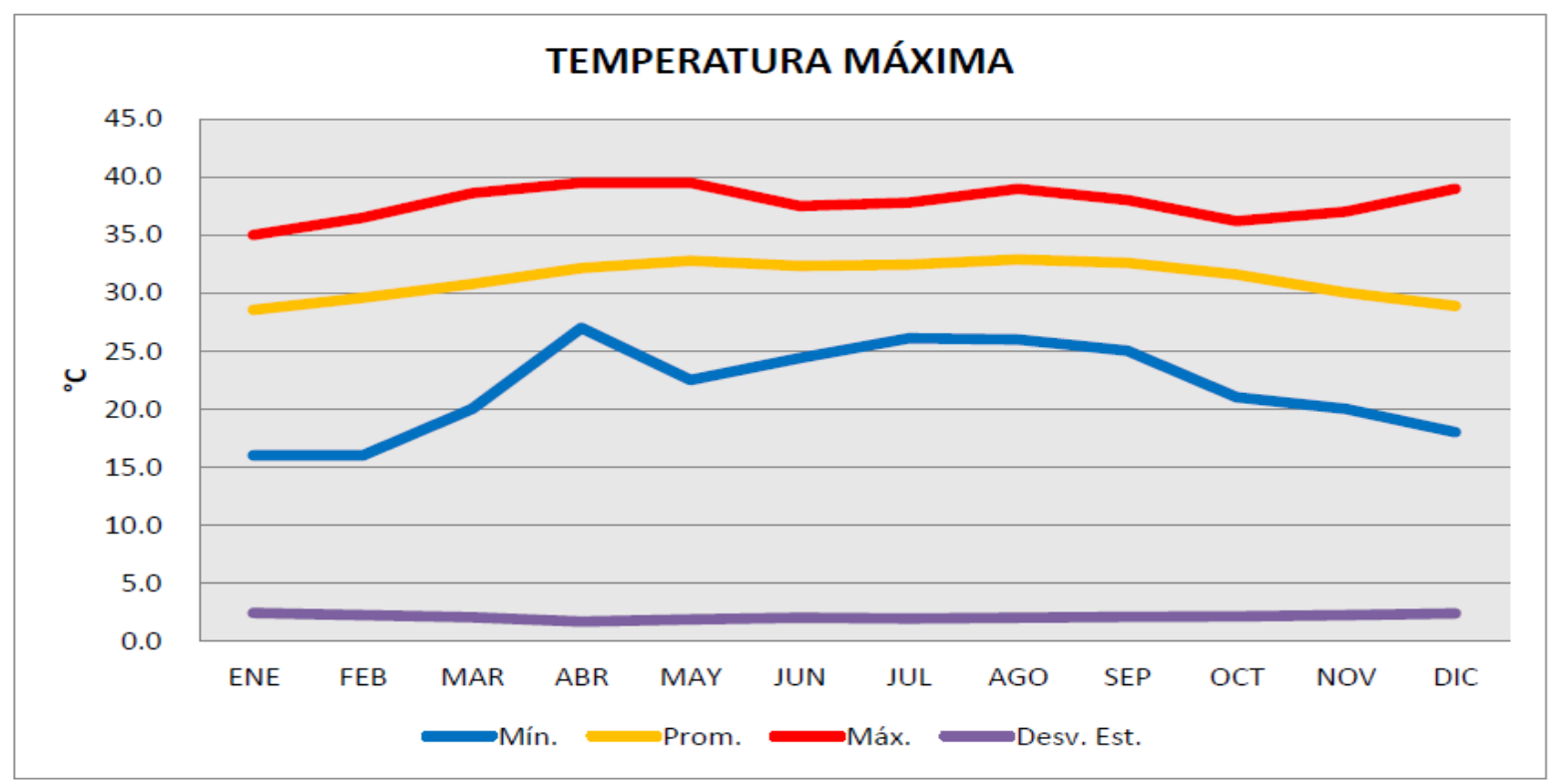

Fuente: CONAGUA, Servicio Meteorológico Nacional, Estaciones Climatológicas. Estación 23032, Chetumal (DGE). 
Por su parte la temporada de mayor precipitación pluvial se extiende de mayo a octubre, destacando los meses de junio y septiembre, correspondiendo de noviembre a abril los meses más secos; siendo este fenómeno recurrente y existiendo la posibilidad de inundaciones sobre todo en áreas aledañas al humedal, debido a las características naturales de la zona, los riesgos y vulnerabilidad a que están expuestos los asentamientos humanos, como ya se ha presentado en varias ocasiones.

Figura 8. Promedio diario de lluvia y temperatura media, 1952-2012

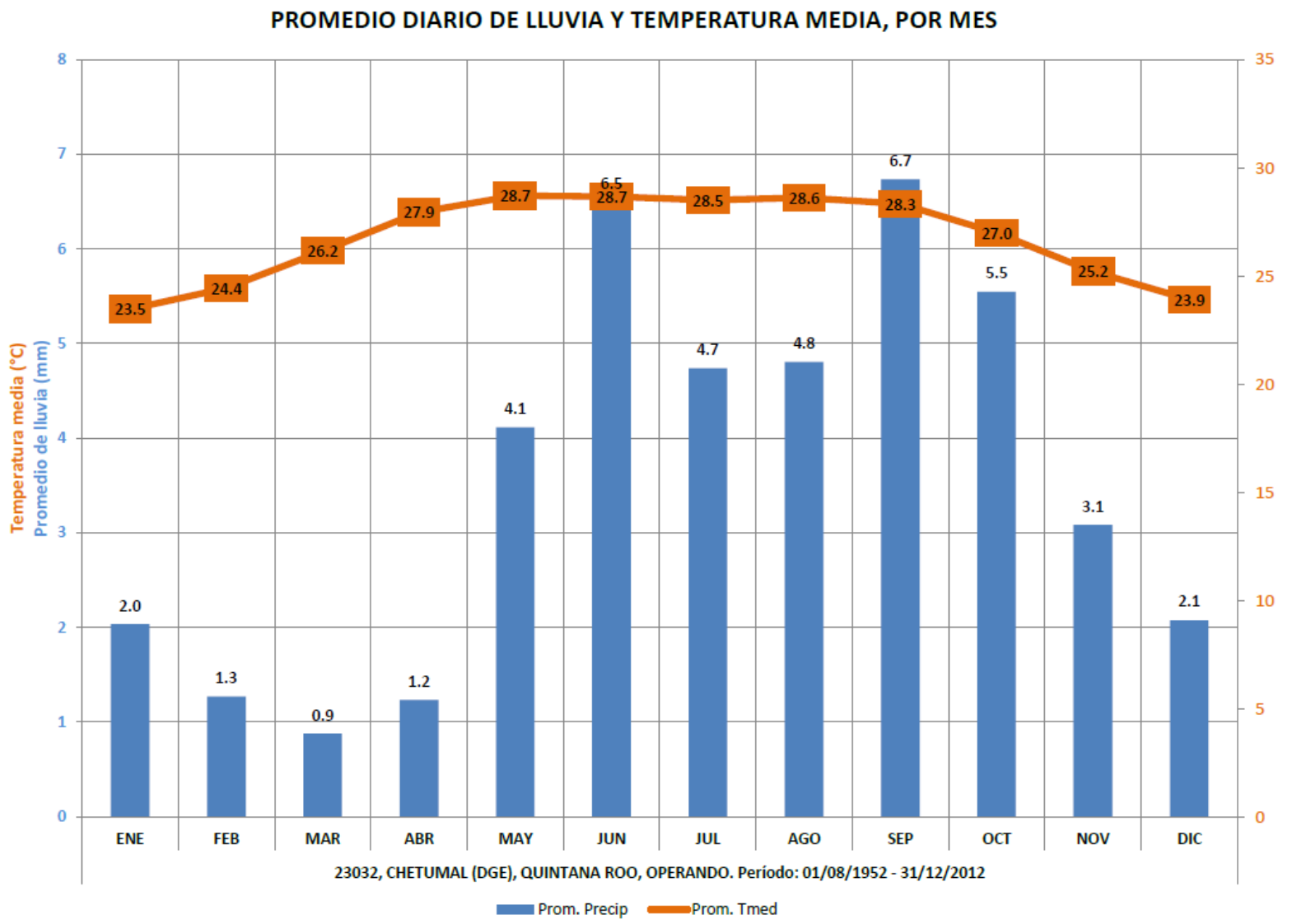

Fuente: CONAGUA, Servicio Meteorológico Nacional, Estaciones Climatológicas. Estación 23032, Chetumal (DGE).

Como puede observarse en la Figura 9, a nivel histórico, destacan los meses de octubre en la década de 1950 con una precipitación de 308 mm; el mes de junio en 1970, con 360 mm; el mes de mayo en 1980 con 276 mm; y el mes de agosto en el año 2000, con $212 \mathrm{~mm}$. 
Figura 9. Promedios de lluvia históricos, Chetumal 1952-2012

PROMEDIO Y MÁXIMO DE LLUVIA, POR DÉCADA MES

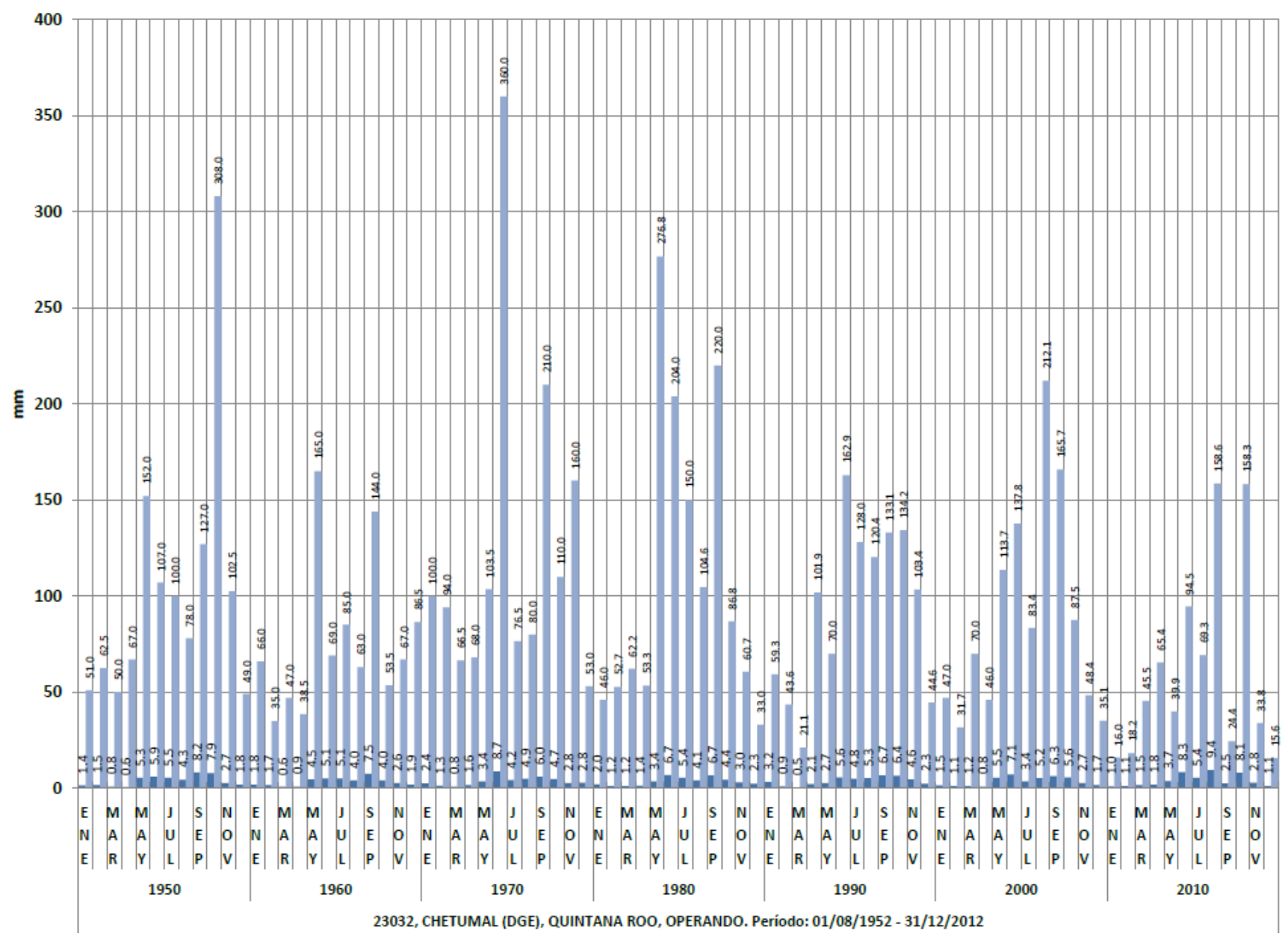

Fuente: CONAGUA, Servicio Meteorológico Nacional, Estaciones Climatológicas. Estación 23032, Chetumal (DGE).

En 2015 se registró una lluvia extrema que aunado a la afectación del drenaje superficial del humedal por los caminos de terracería que lo atravesaban, inundó la ciudad en la zona de estudio, por lo que se tuvieron que romper algunas franjas de los caminos para permitir el desfogue de "La Sabana". Esto es importante dado que cada año existe la probabilidad de inundaciones en la mitad del año lluvioso, y esta probabilidad se incrementa cada 20 años, como se observó en los datos históricos. 


\subsection{6 Áreas Naturales Protegidas y Humedales de importancia internacional} Las Áreas Naturales Protegidas (ANP) en la zona de estudio corresponden a la "Reserva estatal santuario del manatí", la cual fue decretada ${ }^{32}$ el 24 de octubre de 1996, es una reserva Estatal, con una superficie total de $277,73 \mathrm{Ha}^{33}$., que forma parte de la Bahía de Chetumal y zona continental del municipio de Othón P. Blanco; cabe señalar que es en esta bahía donde "La Sabana" efectúa su desembocadura, y en este sentido forma parte del sistema hidrológico del humedal y la bahía, conformando lo que se anuncia en la convención de RAMSAR.

Así mismo, la Bahía de Chetumal forma parte de la lista de humedales de importancia para la $\mathrm{CONABIO}{ }^{34}$, y la Dirección General de Política Ambiental Integración Regional y Sectorial (DGPAIRS). SEMARNAT, como humedales de las áreas estratégicas para la conservación del manglar ${ }^{35}$.

\footnotetext{
${ }^{32}$ Tomo III, No.24 Extraordinario, 5a época del Periódico Oficial del gobierno del estado. Reformas al decreto, 8 de abril de 2008, donde se cambió la categoría de Zona Sujeta a Conservación Ecológica a Reserva Estatal.

$33 \mathrm{http}: / /$ www.conacyt.mx/cibiogem/index.php/anpl/quintana-roo

${ }^{34}$ Los humedales incluidos en la lista de CONABIO corresponden a las Regiones Hidrológicas Prioritarias definidas por esa institución. Representan zonas de gran extensión geográfica, las cuales generalmente incluyen humedales de diferentes clases, así mismo se incluye en la lista de Humedales de importancia de aguas interiores y costeras, en las cuales se incluyen los humedales y lagunas de la Bahía de Chetumal. 35 Fuente: CONABIO, Anexo 1. Listados de Humedales de importancia institucional. Disponible en: < http://www.inecc.gob.mx/descargas/emc/der_anexo1.pdf>
} 
Figura 10. Áreas Naturales Protegidas " Santuario del Manatí"

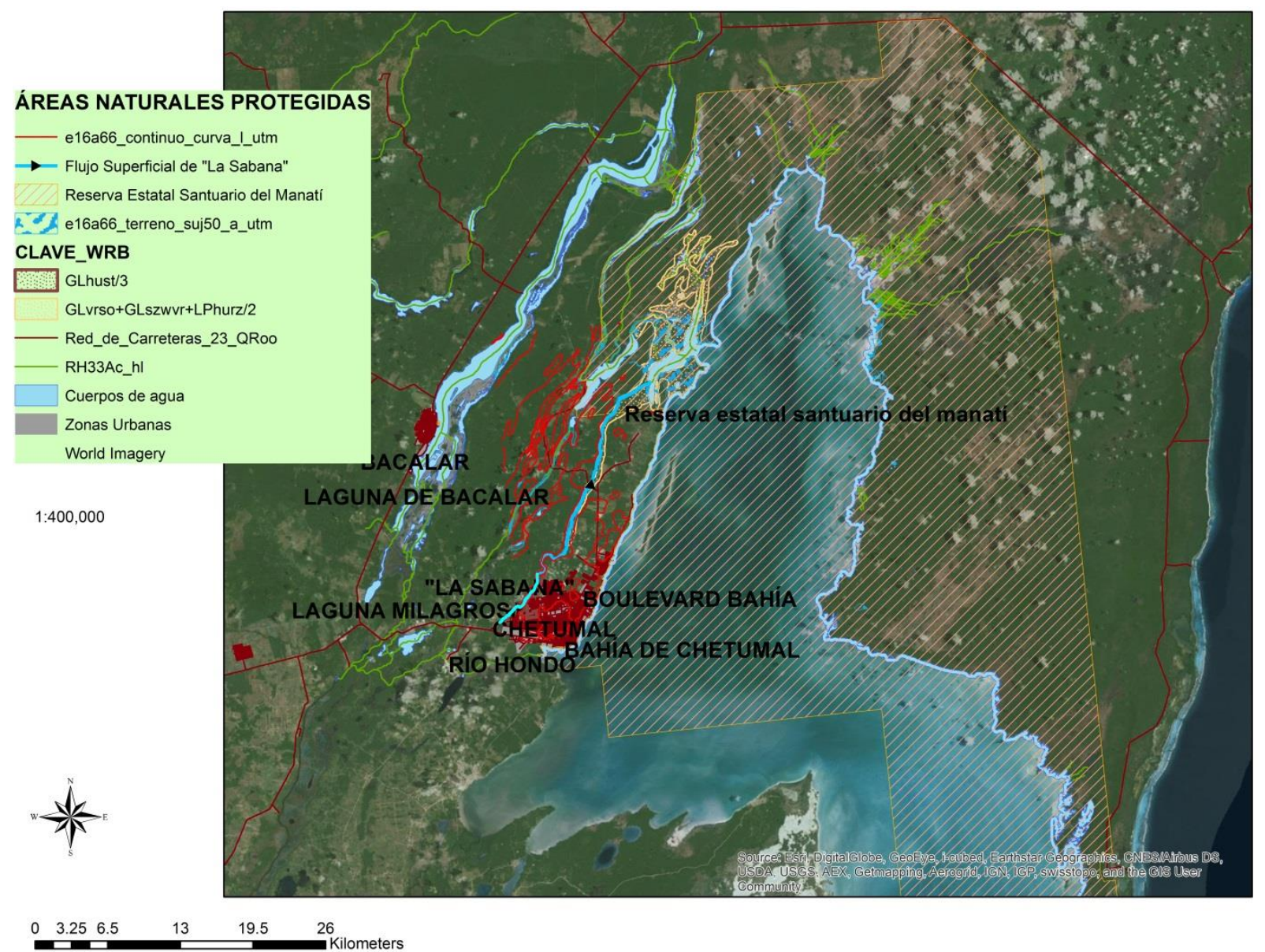

Fuente: Elaboración propia con datos del INEGI, 2010. Programa ArcGis 10.2.

En el municipio de Othón P. Blanco existen dos Humedales declarados de importancia nacional e internacional y registrado en la lista de Humedales de importancia Internacional con arreglo al artículo 2.1 de la Convención de RAMSAR, que son el Parque Nacional Arrecifes de Xcalak en 2003, y la Reserva de la Biosfera Banco Chinchorro en 2004. 
Figura 11. Humedales de importancia Internacional, RAMSAR.

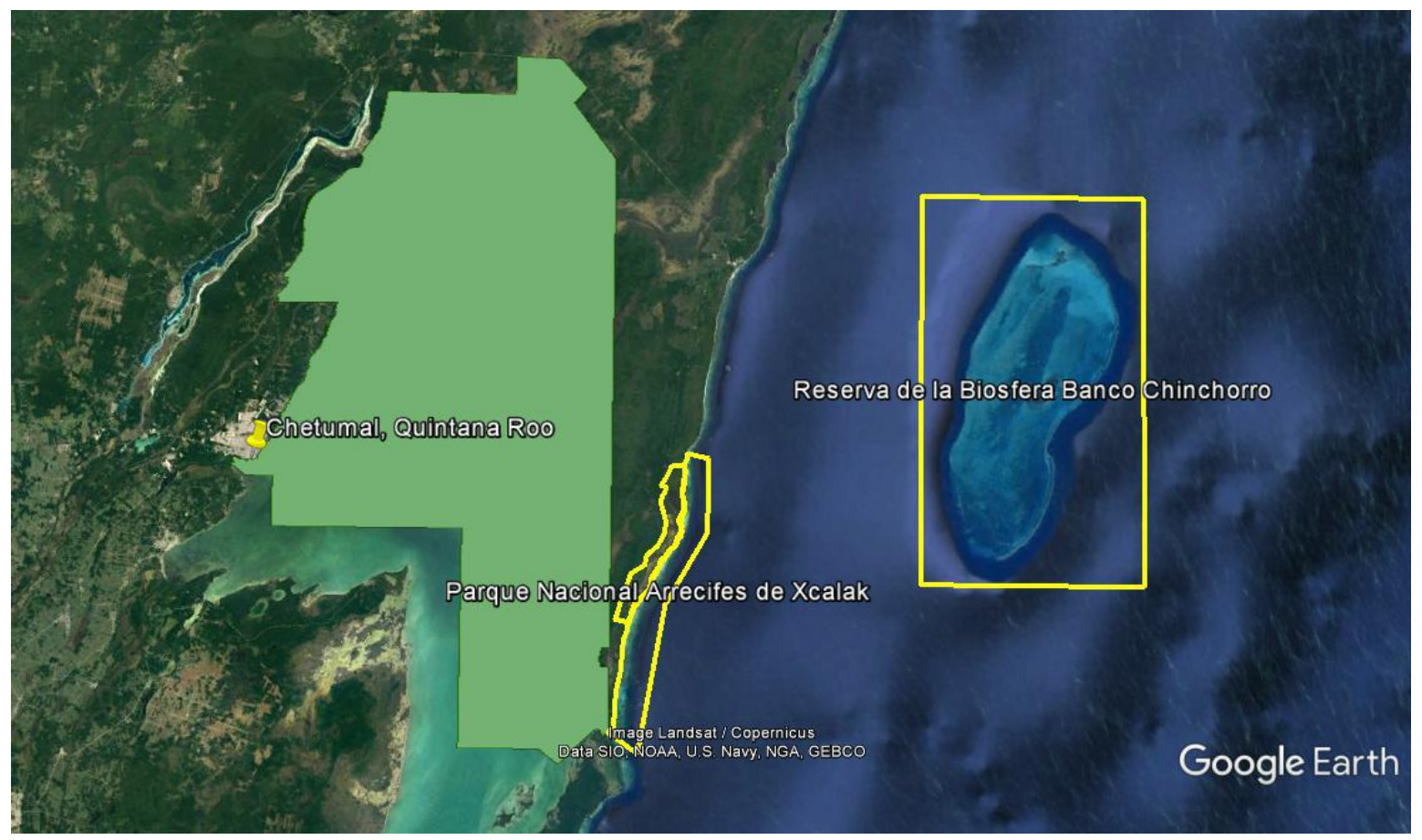

Fuente: Elaboración propia con datos de http://ramsar.conanp.gob.mx//sr.php y Google Earth

\subsubsection{Delimitación del Humedal, límites funcionales, límites urbanos}

Para establecer el límite funcional del humedal "La Sabana" se relacionaron capas cartográficas de tipos de suelo, vegetación, cuerpos de agua, y topografía; finalmente identificando la coincidencia de las primeras capas de información cartográfica y observando que la línea de nivel enmarcaba a estas, se decidió tomar como referencia y límite funcional del humedal esta misma cota (10 msnm). En los casos en los cuales esta información no fue suficiente o no presentaba continuidad espacial, el límite se estableció conforme a imágenes satelitales. Lo anterior se realizó con base en cartografía escala 1:5,000. Como puede observarse los límites funcionales del humedal y los límites urbanos se sobreponen en el perímetro sur del humedal, coincidente con las zonas de inundación como se verá en el siguiente tema. 
Figura 12. Área funcional del humedal "La Sabana"

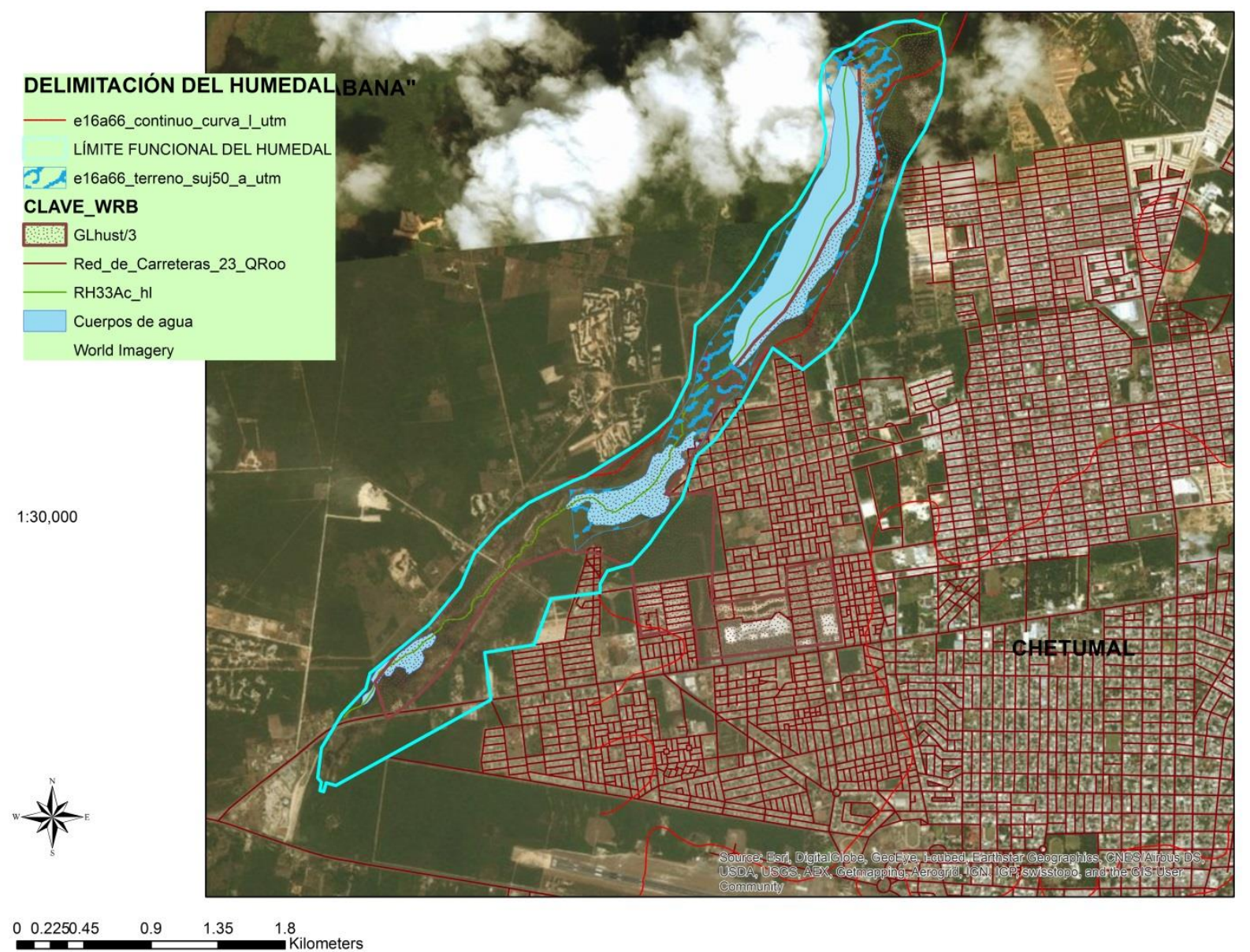

Fuente: Elaboración propia con datos del INEGI, 2010. Programa ArcGis 10.2.

\subsubsection{Riesgos de Inundación}

EI PDU 2018, en su plano correspondiente a "Zonificación Primaria", señala la diferenciación de áreas de la ciudad, de las cuales, señala como Adc (Áreas de desarrollo condicionado), se refieren a poligonales con restricciones para el desarrollo. La construcción o desarrollo urbano en estas zonas está comprometido a la solución y construcción de sistemas integrales de drenaje pluvial que aminore los riesgos de inundación a que están sometidas las colonias circundantes, las cuales son afectadas habitualmente en cada lluvia atípica. En tanto no se atiendan estas necesidades específicas de infraestructura, estas zonas deben considerarse como no aptas para el 
desarrollo urbano y en ese sentido, deberán permanecer exentas de usos urbanos y en todo caso, ser aprovechadas exclusivamente para usos agropecuarios, actividades del sector primario y preferentemente como zonas de preservación ecológica.

Figura 13. Zonificación primaria de la Ciudad de Chetumal, 2018.

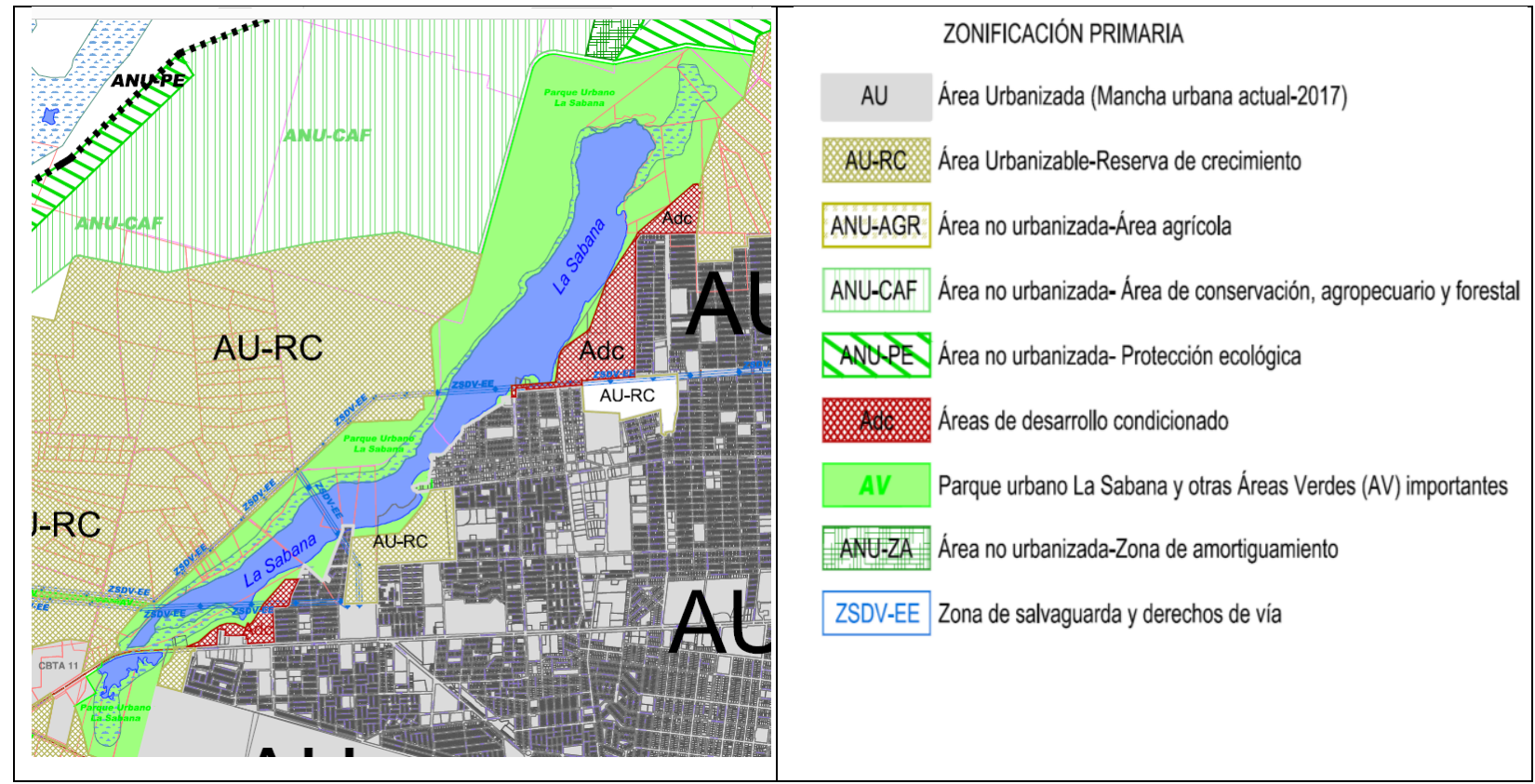

Fuente: Programa de Desarrollo Urbano de Chetumal, Calderitas, Subteniente López, Huay-Pix y Xul-Ha. Municipio de Othón P. Blanco, 2018.

\subsection{Contexto urbano}

\subsubsection{Marco histórico}

Payo Obispo se fundó oficialmente el 5 de mayo de 1898, y en el transcurso de ese mes se inició el trazo de la localidad. El 28 de septiembre de 1936 la localidad de Payo Obispo, cambió su nombre por Chetumal.

Payo Obispo era un asentamiento incipiente cuando se creó el Territorio de Quintana Roo y así se mantuvo durante dos décadas, ya que entre 1902 y 1922, el poblado constaba de cinco vialidades de sur a norte y siete, de este a oeste. Partiendo de sur a norte, las vías -llamadas "avenidas"-, recibieron los nombres de 22 de enero, 22 de Marzo, Othón P. Blanco, Del Ébano y De Zaragoza. Las “calles", que iban de este a oeste, fueron 
bautizadas como: De la Reforma, Hidalgo, 15 de septiembre, 5 de Mayo, 2 de Abril, Benito Juárez e Independencia. En ese sentido, y partiendo de que las colindancias marítimas de Payo Obispo se orientaban hacia el sur y hacia el este, la tendencia de crecimiento del poblado era hacia el norte y hacia el oeste, y estaban delimitadas por la avenida de Zaragoza y por la calle de la Independencia (Rafael Romero y Jazmín Benítez, 2014).

Dicha traza es prácticamente similar a la del croquis de 1922, en el que se aprecia la nomenclatura de sus vialidades. Ello hace suponer que, en cuanto a su traza, Payo Obispo se mantuvo así hasta finales de los años veinte del siglo pasado, cuando se comienza a presentar un relativo crecimiento en su infraestructura vial. Payo Obispo contaba con pocos servicios y espacios aparte de los militares, marítimos y administrativos. En un plano de 1920, reproducido en 1960, la parte "céntrica" del poblado se conformaba por los siguientes elementos: muelle fiscal, garita, aduana, bodega aduanal, carbonera, muelle de gobierno, astillero, hospital, taller mecánico, cuartel militar, excusado de la tropa, parque central, quiosco, cine, muelle y excusado de la aduana, muelle y excusado de gobierno, además de dos embarcaciones emblemáticas para la historia de payo Obispo: el pontón y el Stanford (Rafael Romero y Jazmín Benítez, 2014).

Figura 14. Trazado de las primeras vialidades de Payo Obispo en 1902.

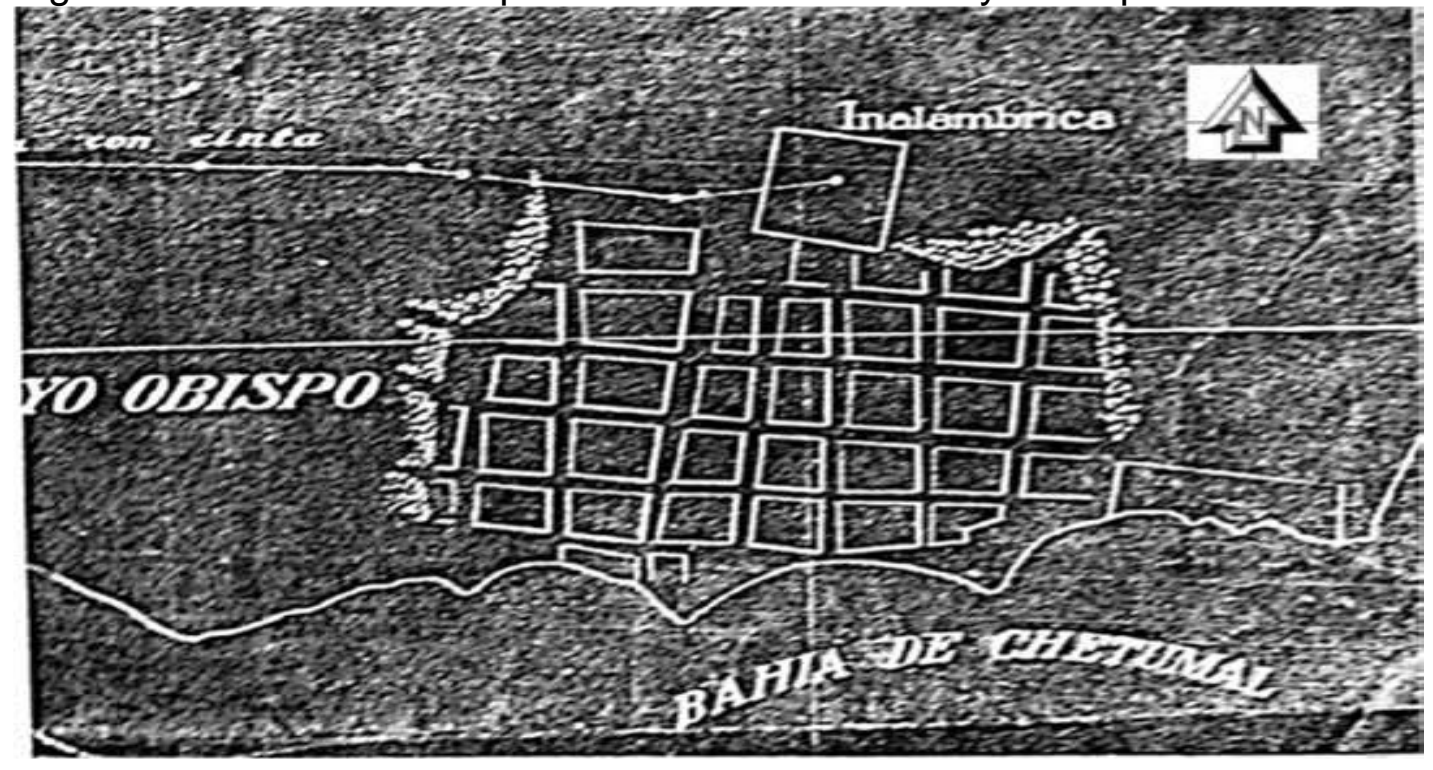

Fuente: Archivo General del Estado de Quintana Roo (Rafael Romero y Jazmín Benítez, 2014). 
Figura 15. Traza Vial de Payo Obispo en 1922.

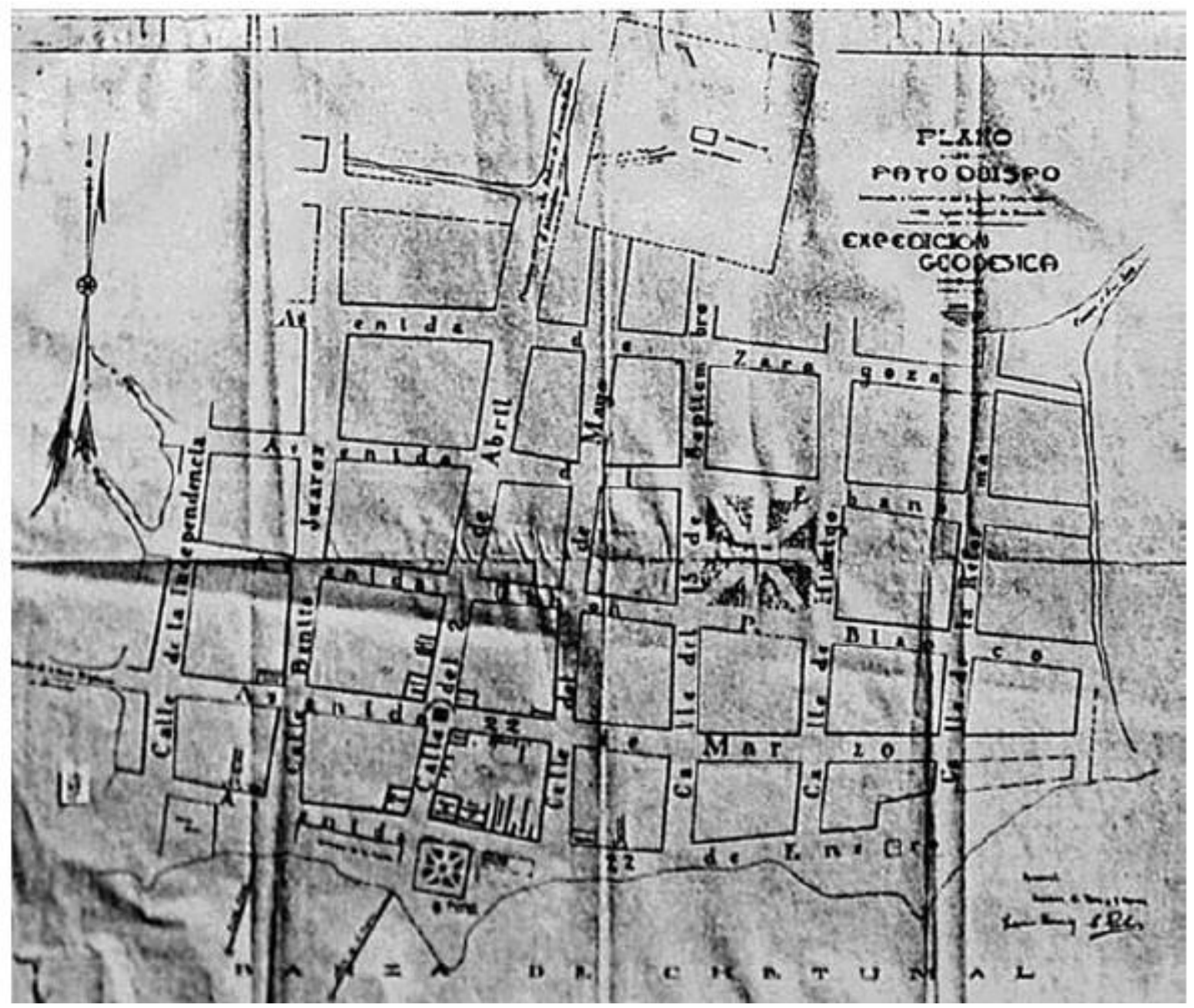

Fuente: Archivo General del Estado de Quintana Roo (Rafael Romero y Jazmín Benítez, 2014).

En cuanto a la tipología de las viviendas, las primeras casas construidas en 1898 y durante varias décadas después, fueron de madera a partir de un concepto de tipo Victoriano por influencia de la Honduras Británica (hoy Belice) y que se pueden encontrar prácticamente por todo el Caribe insular y continental. Este tipo de viviendas se caracterizan por paredes construidas con placas de madera machihembradas (sistema de tablas ensambladas con bordes rebajados) y cubiertas de lámina metálica. Como sistema de captación de agua se utilizaban curbatos (cisternas de madera sobre el nivel del terreno) (Rafael Romero y Jazmín Benítez, 2014).A su vez, muchas de esas viviendas 
eran desplantadas separadas del suelo por una estructura de madera, tipo palafitos, para evitar la humedad excesiva y favorecer la ventilación (Rafael Romero y Jazmín Benítez, 2014).

Figura 16. Payo Obispo, faro y reloj público, antigua calle "2 de Abril" y antigua Av. "22 de Marzo" (hoy Av. Héroes y Av. Carmen Ochoa de Merino

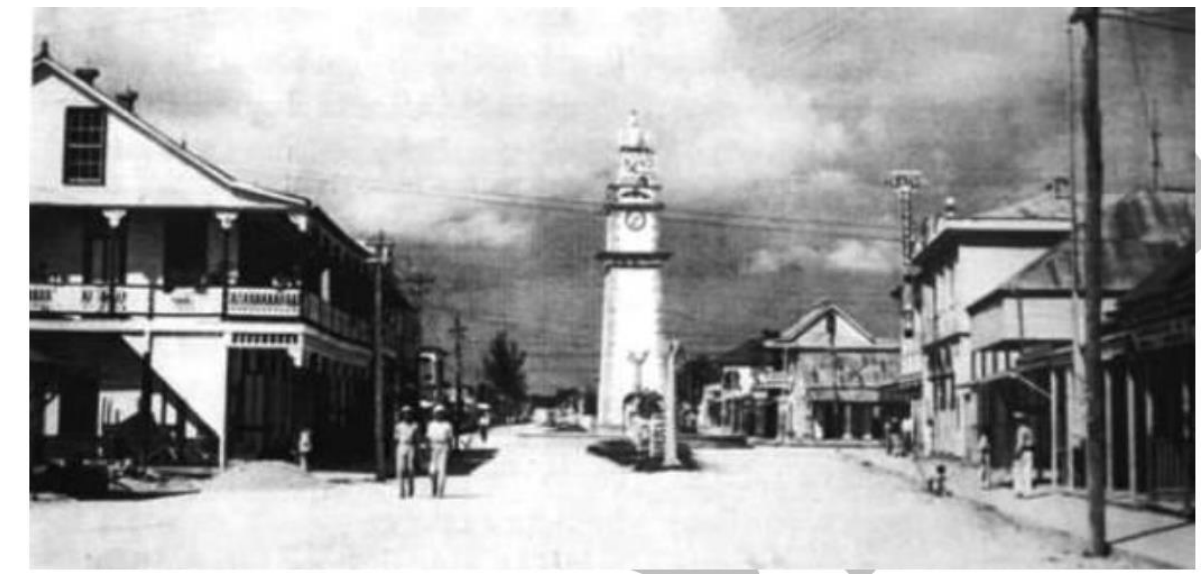

Fuente: Dirección de Desarrollo Urbano, Municipio de Othón P. Blanco. Programa de Desarrollo Urbano de Chetumal, Calderitas, Subteniente López, Huay-Pix y Xul-Ha. Municipio de Othón P. Blanco, 2018.

Lo que es característico de las casas de Chetumal, además de su sistema constructivo, es el colorido, lo que representa el carácter alegre y optimismo del pueblo caribeño. Esta situación habría de cambiar a partir de 1955, con la llegada del huracán Janet, a partir del cual las casas de madera serían sustituidas paulatinamente por construcciones de block y concreto.

\subsubsection{Crecimiento histórico y tendencias de crecimiento urbano}

A partir de 1925, Payo Obispo, presenta un crecimiento adaptándose a los límites físicos geográficos de la Bahía de Chetumal, extendiéndose hacia comunidades cercanas como Punta Estrella y posteriormente a las líneas de infraestructura como la vialidad que lo comunica con el poblado de Calderitas, con el que posteriormente formaría una conurbación física. 
Figura 17. Plano de Payo Obispo, 1925

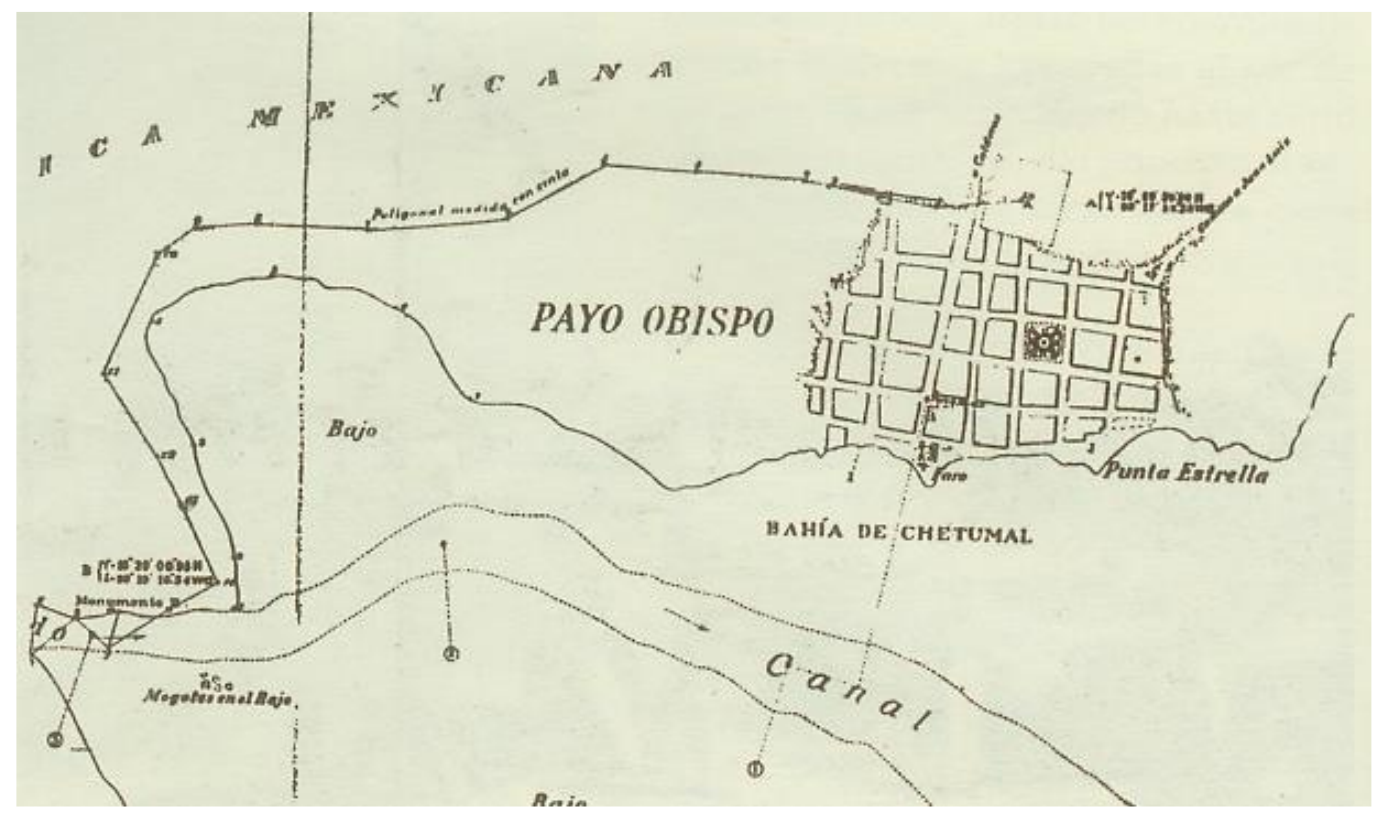

Fuente: Programa de Desarrollo Urbano de Chetumal, Calderitas, Subteniente López, Huay-Pix y Xul-Ha. Municipio de Othón P. Blanco, 2018.

A pesar de mantener su crecimiento, Chetumal careció de muchos servicios desde su creación, y los pocos que tenía eran deficientes: sistema de drenaje, suministro de agua potable, energía eléctrica, calles y avenidas pavimentada que permanece hasta el día de hoy, banquetas, guarniciones, vías de comunicación aérea y terrestre, entre otras (Rafael Romero y Jazmín Benítez, 2014).

Continuando con Rafael Romero (2014), el 27 de septiembre de 1955, el poblado sufrió uno de los desastres naturales más devastadores de los que su corta historia tenga registro: el huracán Janet. Como resultado de la destrucción casi total de las viviendas de madera de la parte más antigua de Chetumal, el proceso de reconstrucción implicó no sólo recuperar la fisonomía urbana del primer plano de la ciudad, sino también la reubicación de muchas familias en zonas consideradas más seguras -en terrenos elevados-. Lo anterior generó la creación de un nuevo asentamiento urbano en la porción norte de la población, siendo este nuevo asentamiento el límite de Chetumal: la colonia Venustiano Carranza. 
Figura 18. Ubicación de la colonia Venustiano Carranza. 1956.

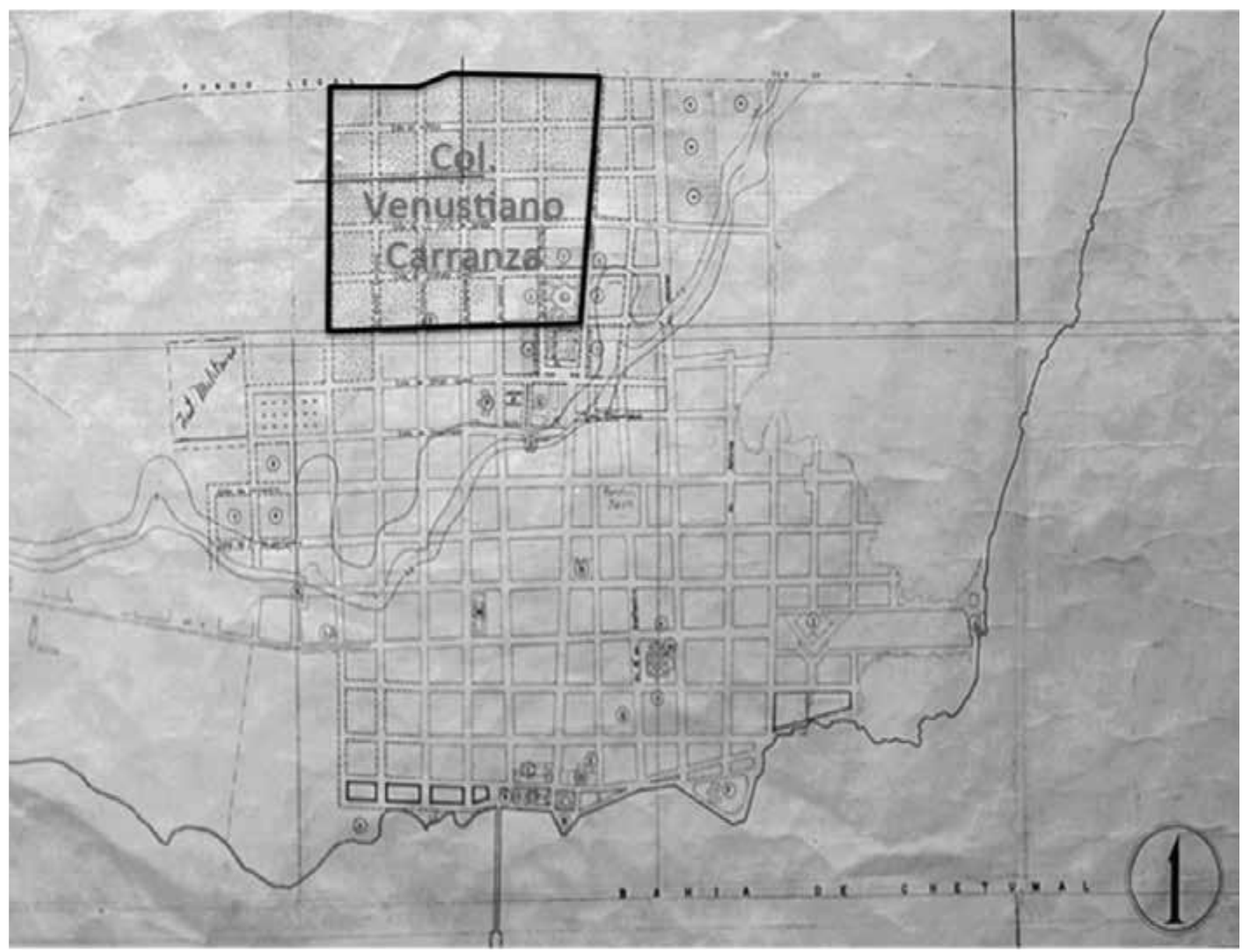

Fuente: Archivo General del Estado de Quintana Roo (Rafael Romero y Jazmín Benítez, 2014). 
Figura 19. Chetumal y su crecimiento poblacional en 1975.

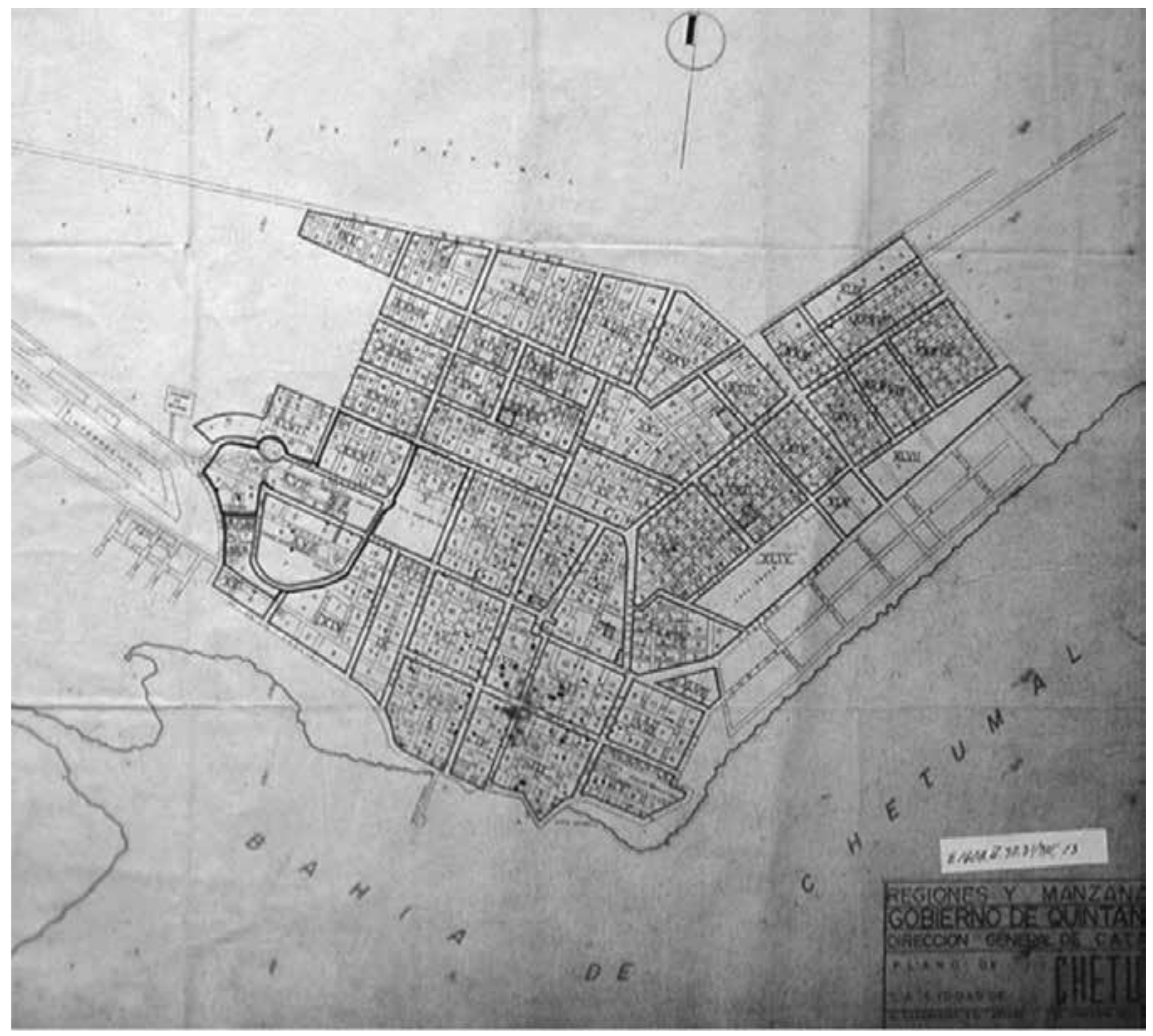

Fuente: Archivo General del Estado de Quintana Roo (Rafael Romero y Jazmín Benítez, 2014).

A partir de la década de los setenta el crecimiento continuaría hacia el norte, este y poniente de la región, en un modelo concéntrico pero limitado al Sur por la Bahía de Chetumal. El desarrollo de nuevas avenidas atrajo nuevos asentamientos humanos y, en el caso del humedal, en condiciones de irregularidad. 
Figura 20. Crecimiento urbano histórico de la Ciudad de Chetumal, 1898-1980

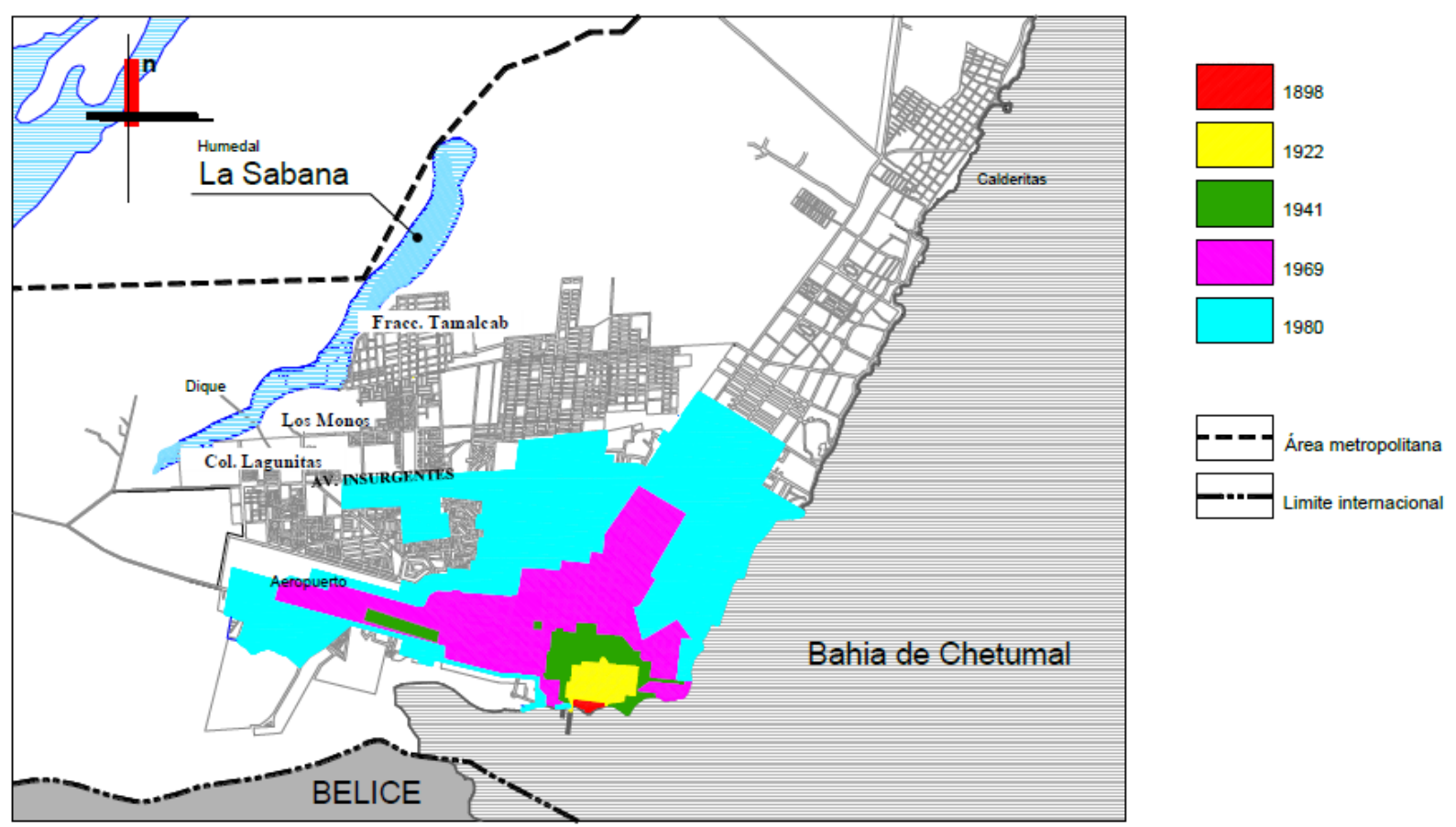

Fuente: Luz, Rangel (2015). Urbanismo y humedales. Caso de estudio: el humedal "La Sabana", desarrollo urbano en la zona noroeste de Chetumal, México. Tesis para obtener el grado de Maestra en Arquitectura. Universidad Veracruzana. Título original: "Aproximación de la mancha urbana de la ciudad de Chetumal con el humedal La Sabana, en 1898" p.85.

A partir de este momento el crecimiento urbano de la ciudad ejercería una presión constante sobre el humedal "La Sabana", propiciado no solo por su crecimiento, sino por la falta de infraestructura, la presencia de asentamientos irregulares, y la creación de caminos de terracería que atravesarían el humedal afectando su funcionamiento natural.

De acuerdo a Luz Rangel (2015) en la década de los 90 la expansión urbana se orientó notablemente hacia dos áreas, la primera hacia la zona Noroeste con mayor aproximación al humedal "La Sabana", con la colonia denominada "Nuevo Progreso" y la segunda en una porción Noreste de la Calzada Veracruz con dirección a la Bahía de Chetumal. Cabe señalar que uno de los principales factores que promovieron ese 
crecimiento, fueron las políticas de urbanización implementadas por las instituciones públicas estatales ${ }^{36}$, que pretendieron reorientar el crecimiento espacial.

Figura 21. Etapas de crecimiento urbano Chetumal 1988-2014.
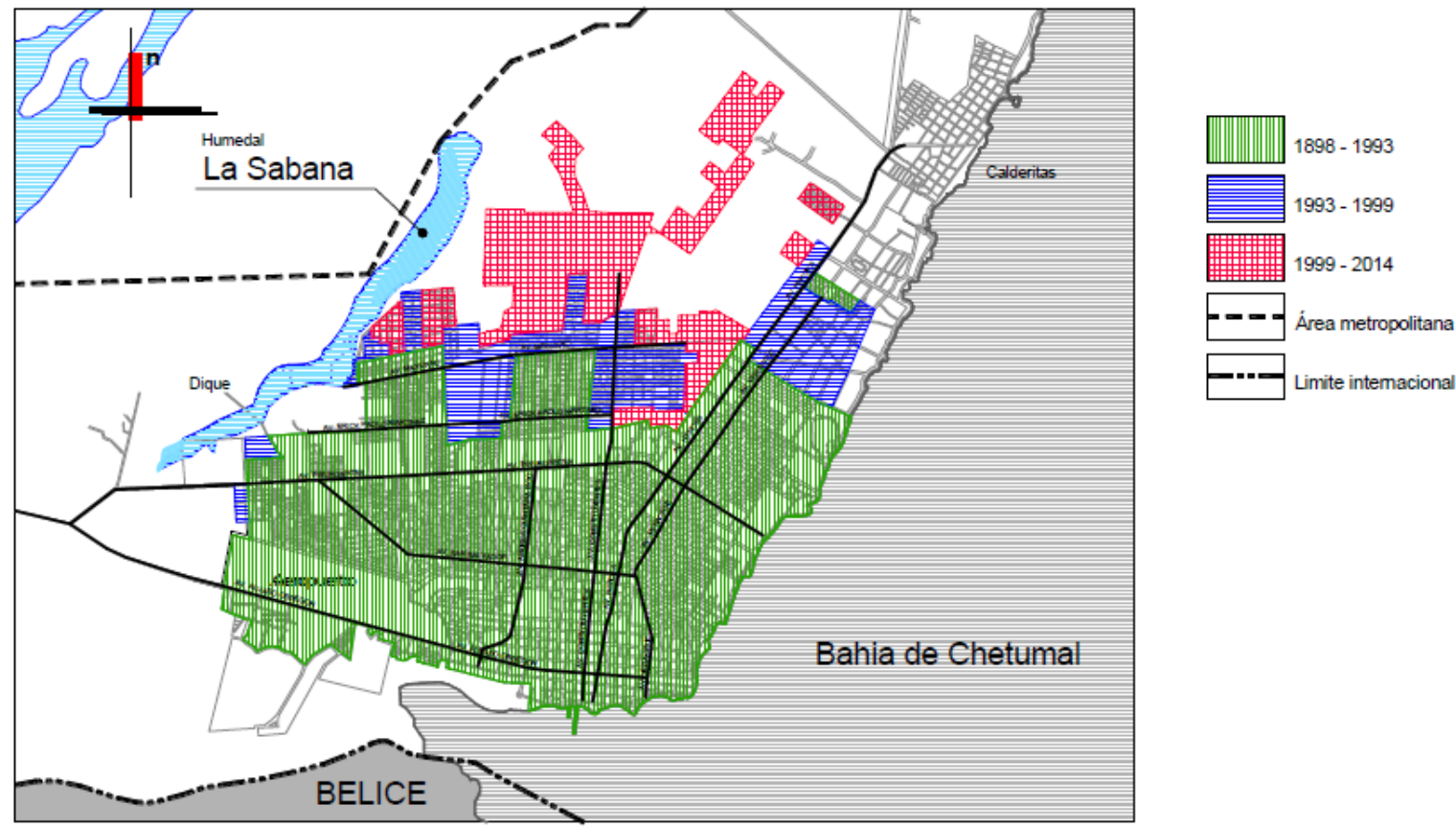

Fuente: Luz, Rangel (2015).

\subsubsection{Estructura urbana y usos del suelo}

El Programa de Desarrollo Urbano del Área Metropolitana del Municipio de Othón P. Blanco de 2005, indicaba en el plano de Uso del Suelo, a la zona colindante con "La Sabana", un uso Habitacional Popular de densidad Alta (151-250 hab/Ha) con una zona de amortiguamiento que bordea cuerpos de agua de lagunas y humedales, y delimitaba el crecimiento del área urbanizable, lo que generaría corredores naturales que interconectaban estos entre sí, y a partir del cual, el resto de la superficie del polígono se consideraba Zona de Conservación Ecológica (PDU, 2005). En la actualidad (2021), la zona que colinda con el humedal sigue siendo en su mayoría de uso habitacional, con

\footnotetext{
${ }^{36}$ Debería referirse a las municipales, que son los encargados de vigilar el desarrollo urbano de la ciudad.
} 
comercio local y usos industriales de almacenamiento y talleres automotrices, especialmente sobre la Av. Insurgentes.

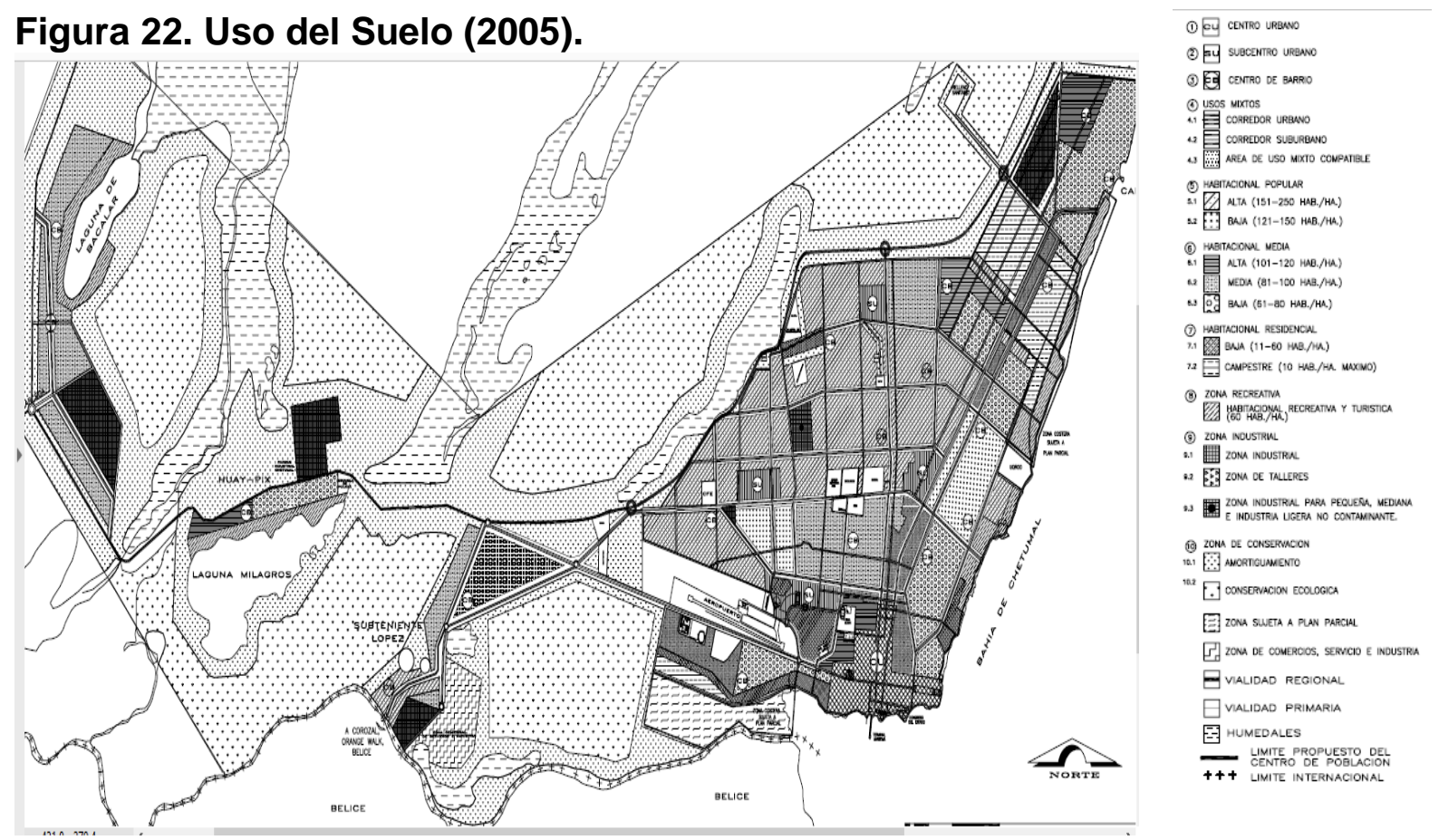

Fuente: Programa de desarrollo urbano del área metropolitana de Chetumal, Calderitas, Xul-há, 2005.

Por su parte, la estructura urbana en la Ciudad es de tipo reticular, obedeciendo a la estructura original del primer asentamiento, con algunos cambios en la orientación de las vialidades principales, para ajustarse a las limitantes geográficas, como la bahía de Chetumal.

En la siguiente figura 23, se observa la carretera que une a Chetumal con el resto de las ciudades del estado y del país; misma que se bifurca, hacia el sur denominada Av. Álvaro Obregón, y al norte (centro) Av. Insurgentes que atraviesa toda la ciudad por la mitad hasta concluir en el Boulevard Bahía. Por su parte la Av. de los Héroes comunica la ciudad de norte a sur, y en su prolongación une a Chetumal con la localidad de Calderitas. En este punto cabe destacar la importancia de las vialidades secundarias: Av. Erick Paolo Martínez y Av. Maxuxac que desembocan en el humedal, de la primera se derivaba un 
camino de terracería que unía la ciudad con algunas rancherías y bancos de material del lado poniente de "La Sabana".

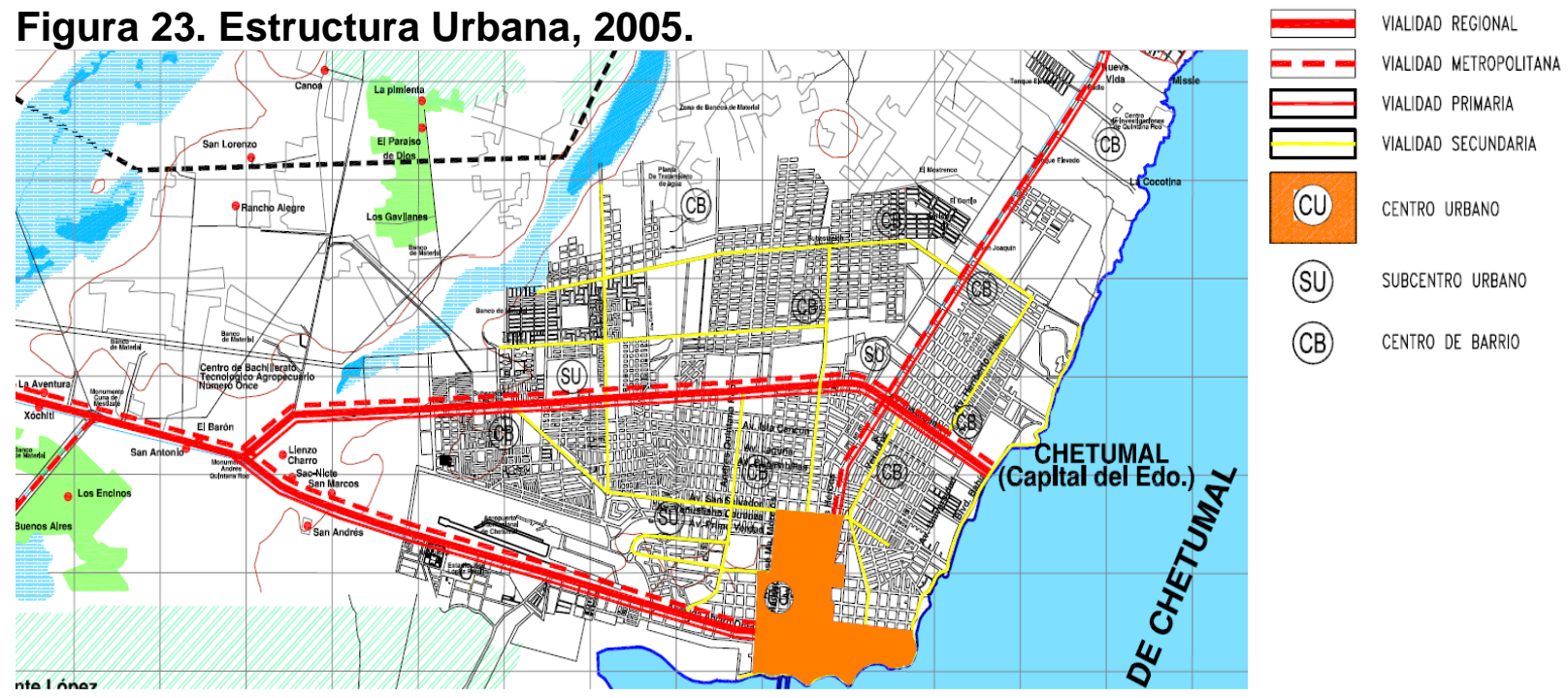

Fuente: Programa de desarrollo urbano del área metropolitana de Chetumal, Calderitas, Xul-Há, 2005.

En la actualidad los dos caminos que atraviesan el humedal pueden verse con claridad en la figura 24.

Figura 24. Caminos que atraviesan el humedal "La Sabana", 2017.

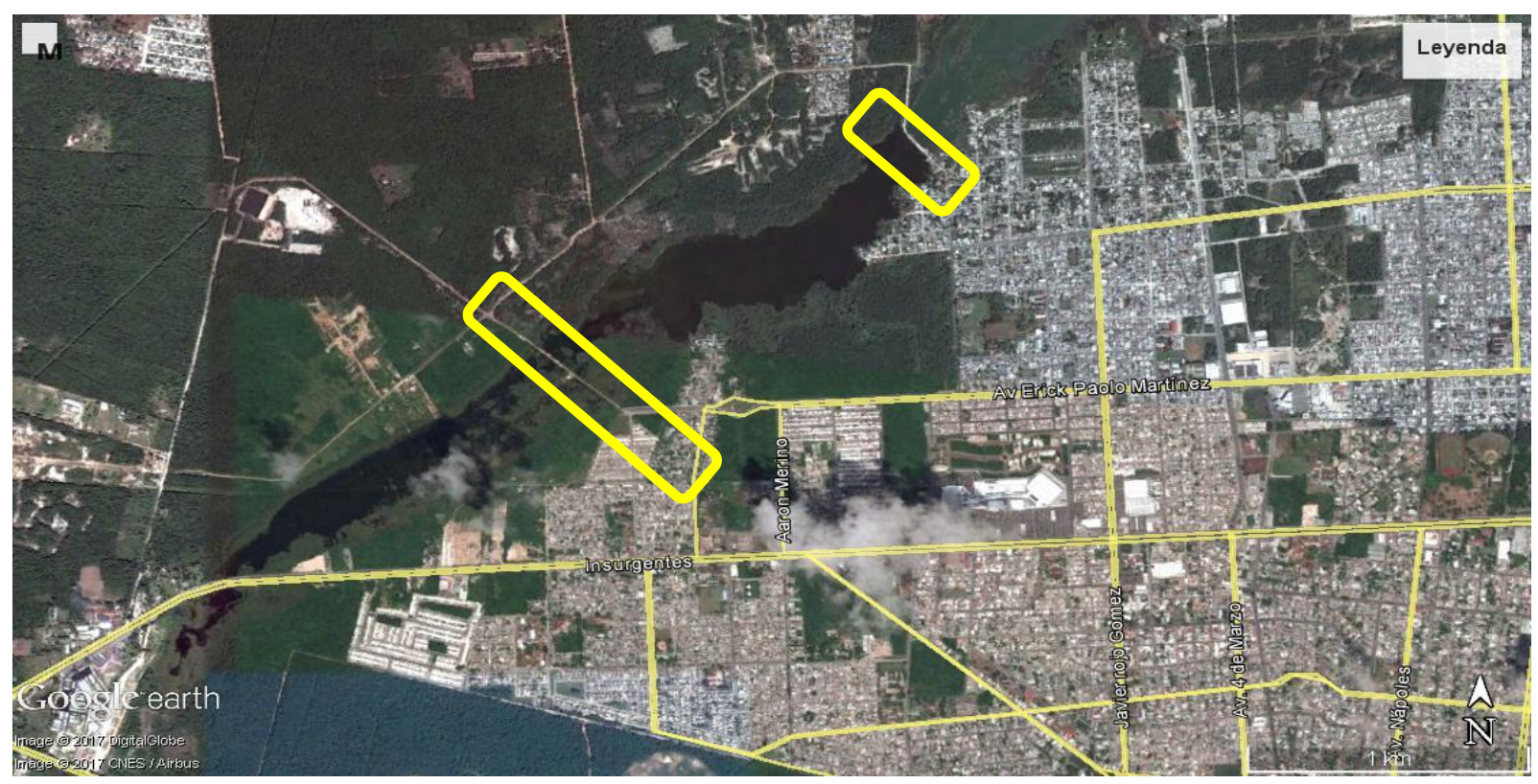

Fuente: Google earth, 2017. 


\subsubsection{Servicios a la vivienda}

En 2005 las viviendas adyacentes al humedal, no contaban con servicio de drenaje, tal como se indica en la figura siguiente, tal como se ha señalado anteriormente esto afecta directamente a "La Sabana", dado que, al no contar con servicio municipal de drenaje, las viviendas o construcciones aledañas, vierten sus deshechos (aguas grises y negras) sin previo tratamiento directamente al cuerpo de agua, provocando su contaminación, sin que exista acción legal alguna hasta el momento.

Figura 25. Servicios a la vivienda, 2005.

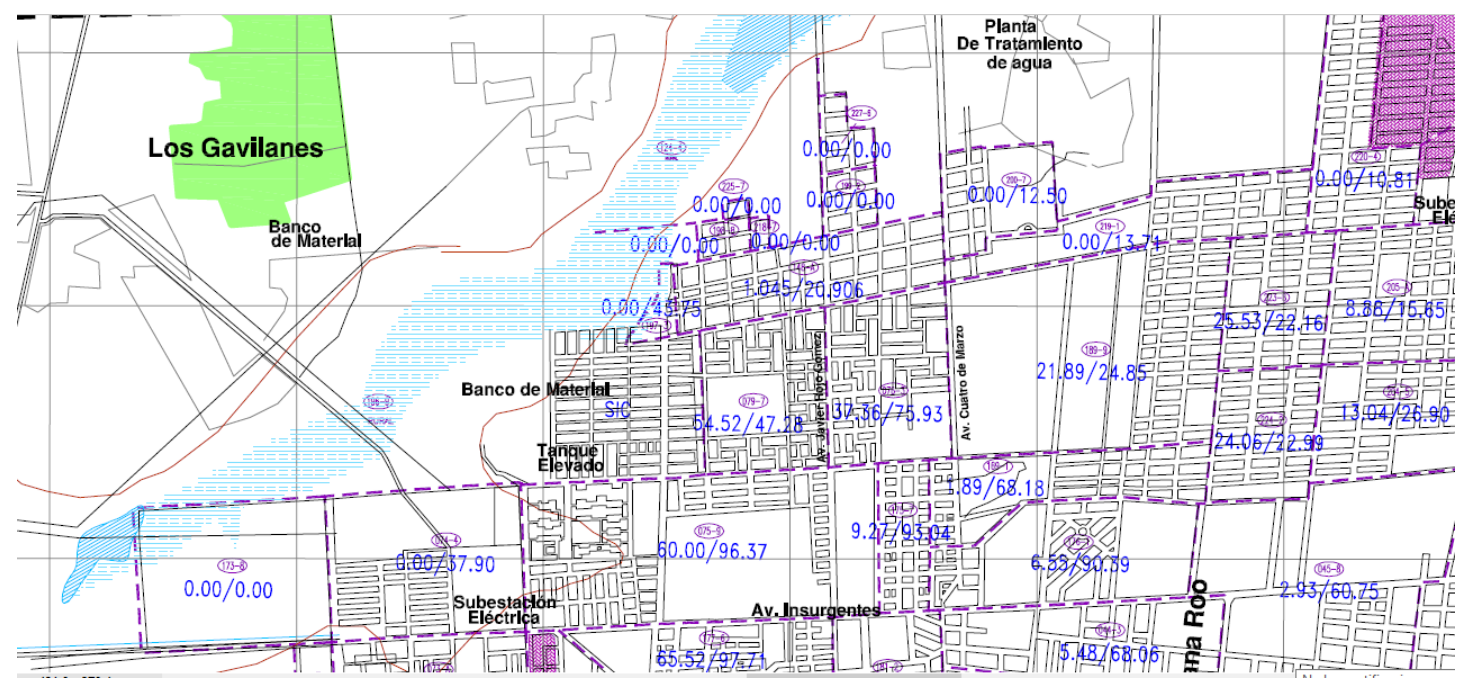

NIVEL DE SERVICIO/AGEB

$0.00 \% / 0.00 \%=\%$ DE VIVIENDAS SERVIDAS CON DRENAJE

$0.00 \% 0.00 \%=\%$ DE VIVIENDAS SERVIDAS CON AGUA ENTUBADA

SIC SIN INFORMACIŌN CENSAL

S.I.C.

Fuente: Programa de desarrollo urbano del área metropolitana de Chetumal, Calderitas, Xul-Há, 2005.

Para el 2018, con la actualización del PDU de Chetumal, el cambio no fue significativo (figura siguiente). 


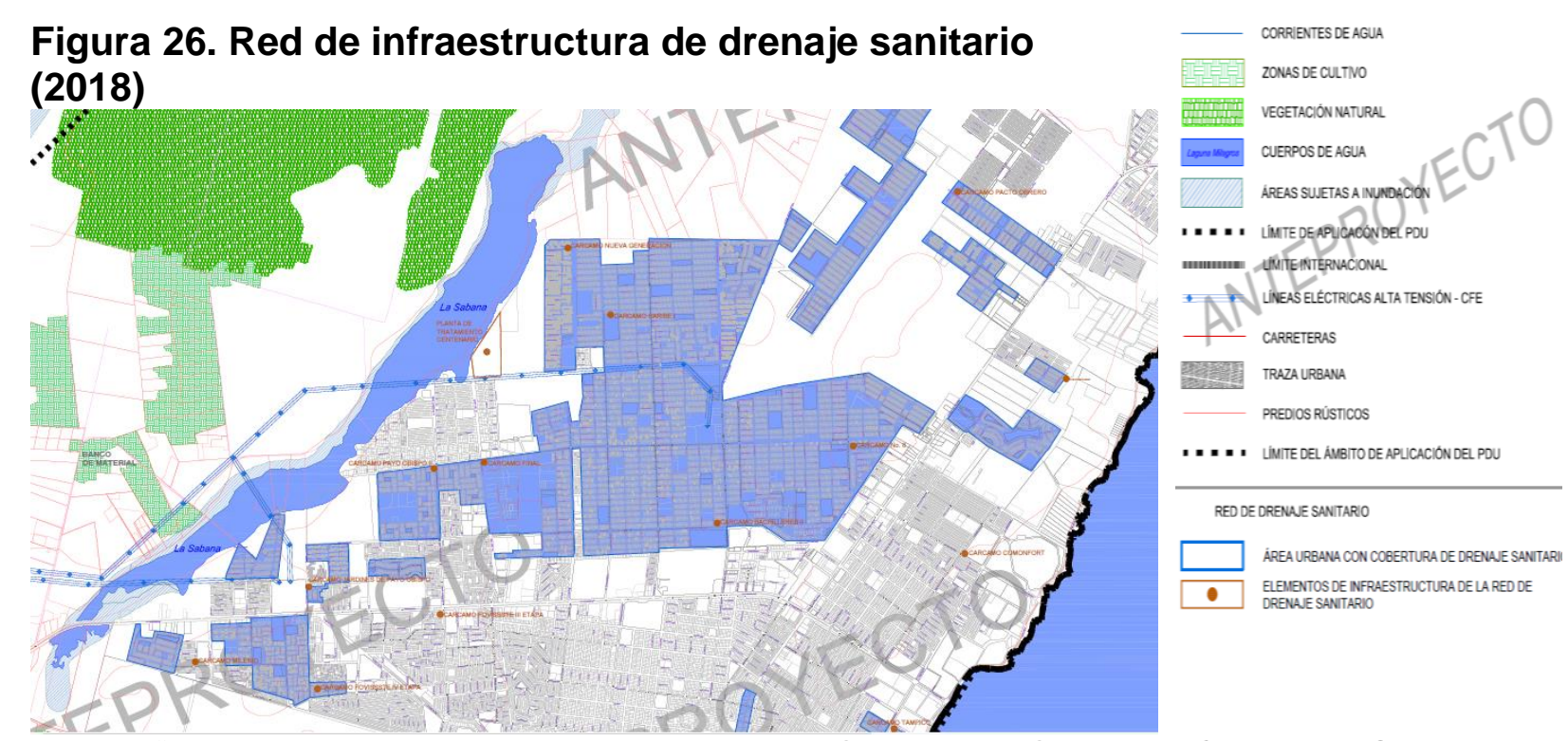

Fuente: "Programa de Desarrollo Urbano de la Ciudad de Chetumal-Calderitas-Subteniente López-Huay-Pix y Xul-Há (2018). Municipio de Othón P. Blanco, Estado de Quintana Roo”.

También puede verse la Planta de tratamiento "Bicentenario", que de acuerdo al Inventario Nacional de Plantas Municipales de Potabilización y de Tratamiento de Aguas Residuales en Operación. Diciembre 2014, de la Comisión Nacional del Agua, vierte sus aguas tratadas al acuífero (figura siguiente), y en este caso se refiere al humedal "La Sabana”.

Figura 27. Plantas Municipales de Tratamiento de Aguas Residuales, referencia: Bicentenario.

Plantas Municipales de Tratamiento de Aguas Residuales en Operación en el estado de Quintana Roo Dic-14

\begin{tabular}{|c|c|c|c|c|c|c|c|}
\hline Municipio & Localidad & Nombre de la planta & Proceso & $\begin{array}{c}\text { Capacidad } \\
\text { instalada } \\
(1 / s)\end{array}$ & $\begin{array}{c}\text { Caudal tratado } \\
\text { (1/s) }\end{array}$ & Cuerpo receptor o reuso & Observaciones \\
\hline Lázaro Cárdenas & Holbox & Holbox & Dual & 5.0 & 2.0 & Acuífero & $\begin{array}{l}\text { Inició operación en } 2005 \\
\text { - operada por CAPA }\end{array}$ \\
\hline Othón P. Blanco & Bacalar & Bacalar & Lodos Activados & 30.0 & 0.4 & Acuífero & \\
\hline Othón P. Blanco & Chetumal & Centenario & Lodos Activados & 120.0 & 85.7 & Acuífero & $\begin{array}{l}\text { Inició operación en } 2000 \\
\text {. Sustituye PTAR' } \\
\text { Chetumal, Fovissste VI y } \\
\text { Payo Obispo, incluye } 17.5 \\
1 / 1 \text { s que tratabab la alaguna } \\
\text { de oxidación que dejó de } \\
\text { operar en } 2002 \text {. }\end{array}$ \\
\hline
\end{tabular}

Fuente: Comisión Nacional del Agua, diciembre 2014. Inventario Nacional de Plantas Municipales de Potabilización y de Tratamiento de Aguas Residuales en Operación. 


\subsubsection{Condiciones de la Vivienda}

En la siguiente figura, se muestra el porcentaje de viviendas particulares habitadas con más de 2.5 ocupantes por dormitorio, y el porcentaje de viviendas particulares habitadas con piso de tierra con respecto del Porcentaje de viviendas particulares habitadas. Podemos observar que existen rangos de hacinamiento y presencia de viviendas de piso de tierra, en la zona de estudio. Estas características denotan la vulnerabilidad de la vivienda y sus habitantes ante fenómenos hidrometeorológicos, además de las características de marginación y carencias sociales, que aportan escaso valor paisajístico al lugar.

\section{Figura 28. Condición de hacinamiento y pisos de tierra en las viviendas, 2010.}

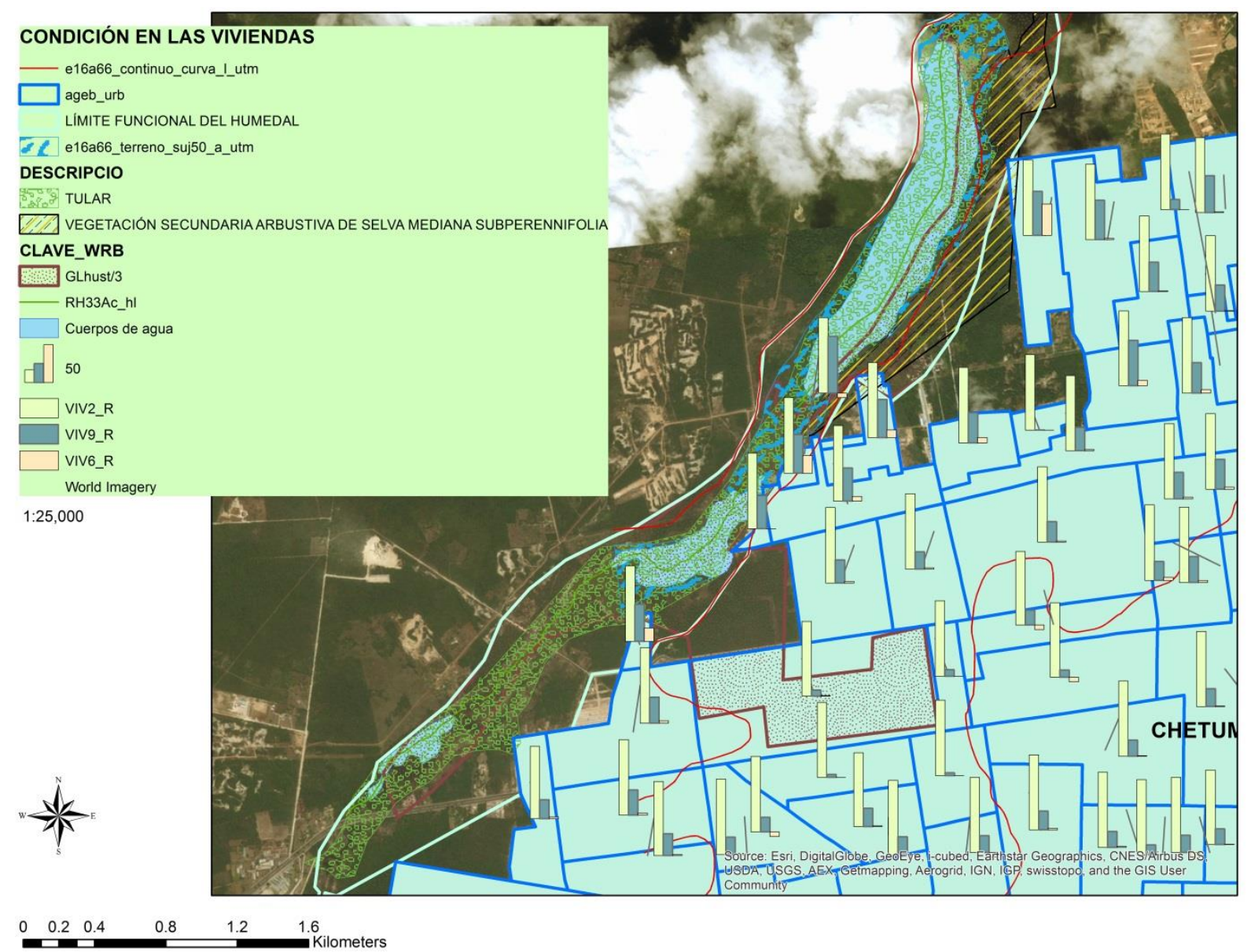

Fuente: Elaboración propia con datos del SCINCE 2010, para Quintana Roo, por AGEB Urbana. Nota: VIV2_R: Viviendas particulares habitadas; VIV9_R: Viviendas particulares habitadas con más de 2.5 ocupantes por dormitorio; VIV6_R: Viviendas particulares habitadas con piso de tierra. 
Por su parte, el SCINCE reporta que las viviendas particulares habitadas cuentan con los servicios básicos de Energía Eléctrica, Agua y Drenaje ${ }^{37}$ (Figura 29). En el caso del drenaje, el INEGI considera que puede estar conectada a barrancas, ríos o cuerpos de agua.

Figura 29. Condición en la vivienda. Servicios Luz, Agua y Drenaje, 2010.

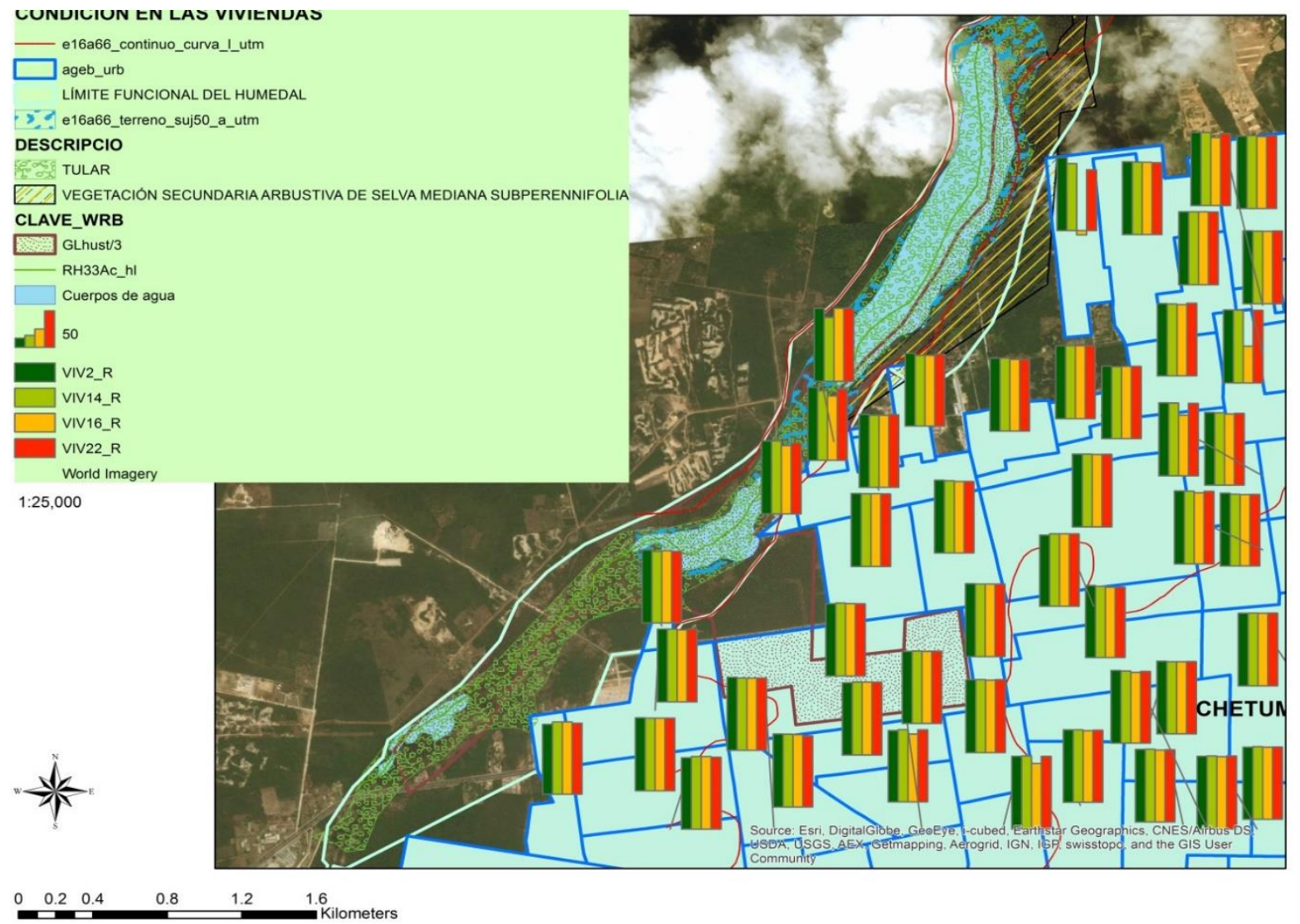

Fuente: Elaboración propia con datos del SCINCE 2010, para Quintana Roo, por AGEB Urbana. NOTA: VIV2_R: Viviendas particulares habitadas; VIV14_R: Viviendas particulares habitadas que disponen de luz eléctrica; VIV16_R: Viviendas particulares habitadas que disponen de agua entubada en el ámbito de la vivienda ;VIV22_R: Viviendas particulares habitadas que disponen de drenaje ${ }^{38}$.

\footnotetext{
${ }^{37}$ A diferencia del PDU de Chetumal, que como se vio anteriormente señala que no cuentan con el servicio de Drenaje.

38 Viviendas particulares habitadas que tienen drenaje conectado a la red pública, fosa séptica, barranca, grieta, río, lago o mar.
} 


\subsubsection{Equipamiento urbano zonal}

En la zona de estudio puede verse una gran predominancia de equipamientos destinados a plazas, instalaciones deportivas y recreativas, un mercado y algunas escuelas. Mientras que, en la zona que colinda directamente al centro del humedal, se puede observar una gran cantidad de edificaciones dedicadas al culto religioso, sin ningún otro equipamiento social, excepto una instalación de tipo educativo.

\section{Figura 30. Equipamiento Urbano, 2010}

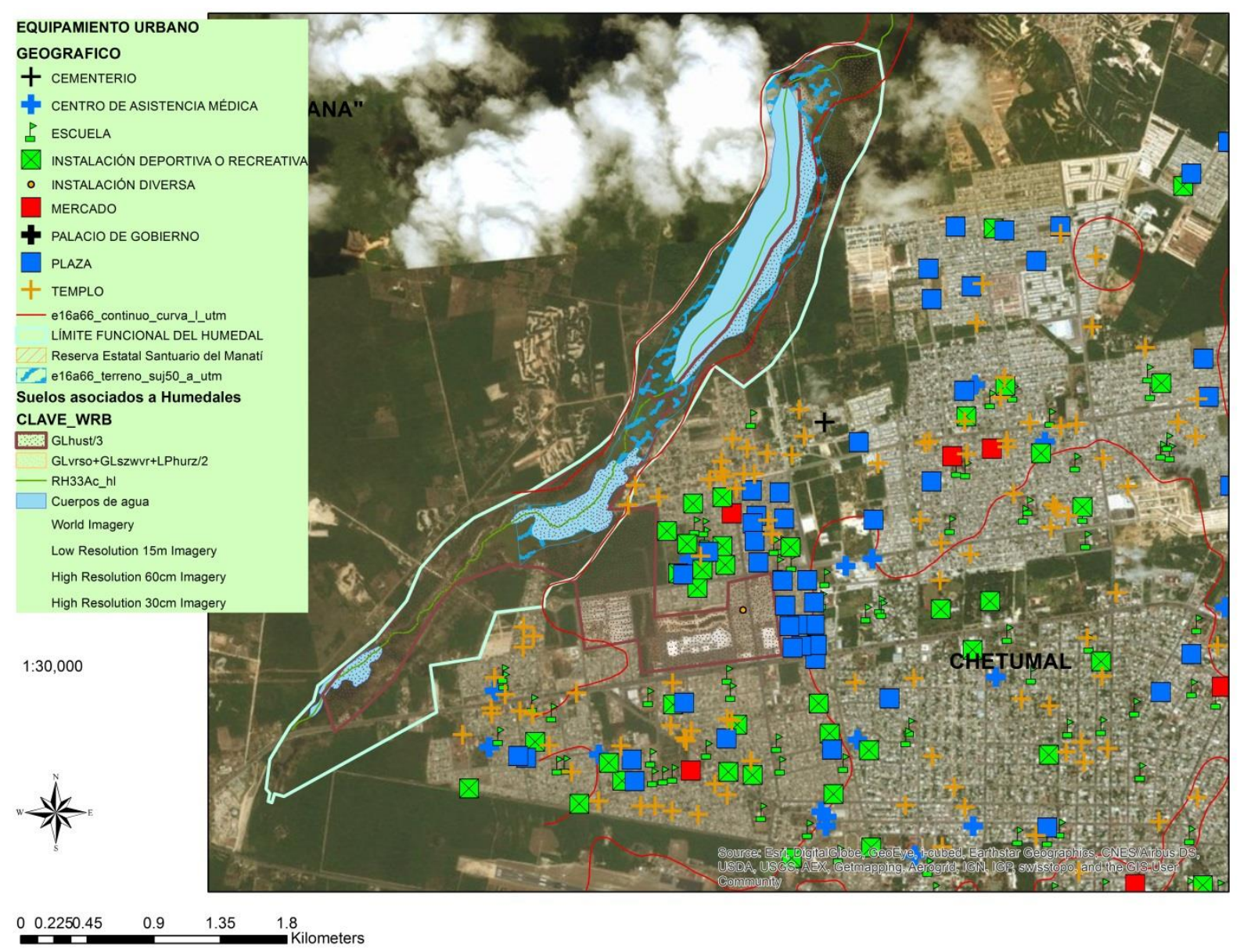

Fuente: Elaboración propia con datos del SCINCE 2010, para Quintana Roo, por AGEB Urbana. 


\subsection{6 Áreas verdes urbanas}

Algunos de los espacios abiertos identificados corresponden a diversas tipologías de equipamientos contemplados en el Sistema Normativo de Equipamiento Urbano (SEDESOL, 1999), como parte del Subsistema Recreación ${ }^{39}$, y en algunos casos, por el tipo de diseño predominantemente abierto en la Ciudad de Chetumal, también al Subsistema Deporte, dado que "Propician la comunicación, interrelación e integración social, así como la convivencia con la naturaleza y la conservación de la misma dentro de las áreas urbanas, coadyuvando al mejoramiento ecológico de las mismas" (SEDESOL, 1999).

La dotación de equipamiento de áreas verdes urbanas en la zona de estudio, está integrada por parques de barrio, el zoológico municipal, canchas y unidades deportivas del Instituto Tecnológico de Chetumal, y Escuelas públicas que suman sus espacios arborizados a la ciudad, que como se verá más adelante en la figura 31, están vinculadas por su cercanía una de otras y por vías primarias como la Av. Insurgentes, conformando un posible corredor verde.

Así mismo, recuperando el concepto de la ecología del paisaje y de las áreas verdes urbanas, se puede incluir otro tipo de equipamientos y áreas verdes que cumplan con estas características para formar corredores, redes y nodos dentro de la estructura urbana y que conecte con su área circundante y zonas de transición o zonas de espacios abiertos: los recursos naturales valiosos, como los bosques maduros, los humedales, lagos, manglares y vistas panorámicas ${ }^{40}$, o como señala el Reglamento de Paisaje de la Comunidad Valenciana ${ }^{41}$ : áreas de conexión entre los espacios de interés para lograr una continuidad física, ecológica y funcional; y que en este sentido puede incluir cementerios ${ }^{42}$, bulevares, avenidas, camellones, áreas verdes privadas, áreas verdes sin uso, parques ecológicos y otros tipos de conexiones naturales ${ }^{43}$.

\footnotetext{
39 Excepto por las salas de cine

$40 \mathrm{http}: / / \mathrm{goo} . \mathrm{gl} / \mathrm{pbaQyw}$ también incluye playas y cintas costeras

41 (Decreto 120/2006, de 11 agosto

42 Lo que agrega un valor cultural

${ }^{43}$ Incluso algunas escuelas pueden formar parte de estas áreas verdes urbanas.
} 
Por las características antes señaladas conviene visualizar la ciudad de Chetumal a una escala más general, donde puedan visualizarse posibles conexiones entre equipamientos y más específicamente corredores verdes urbanos. Como tal se señala en la figura 31 , corredores o conexiones entre lo urbano y lo natural.

Figura 31. Equipamentos asociados a áreas verdes urbanas, 2010

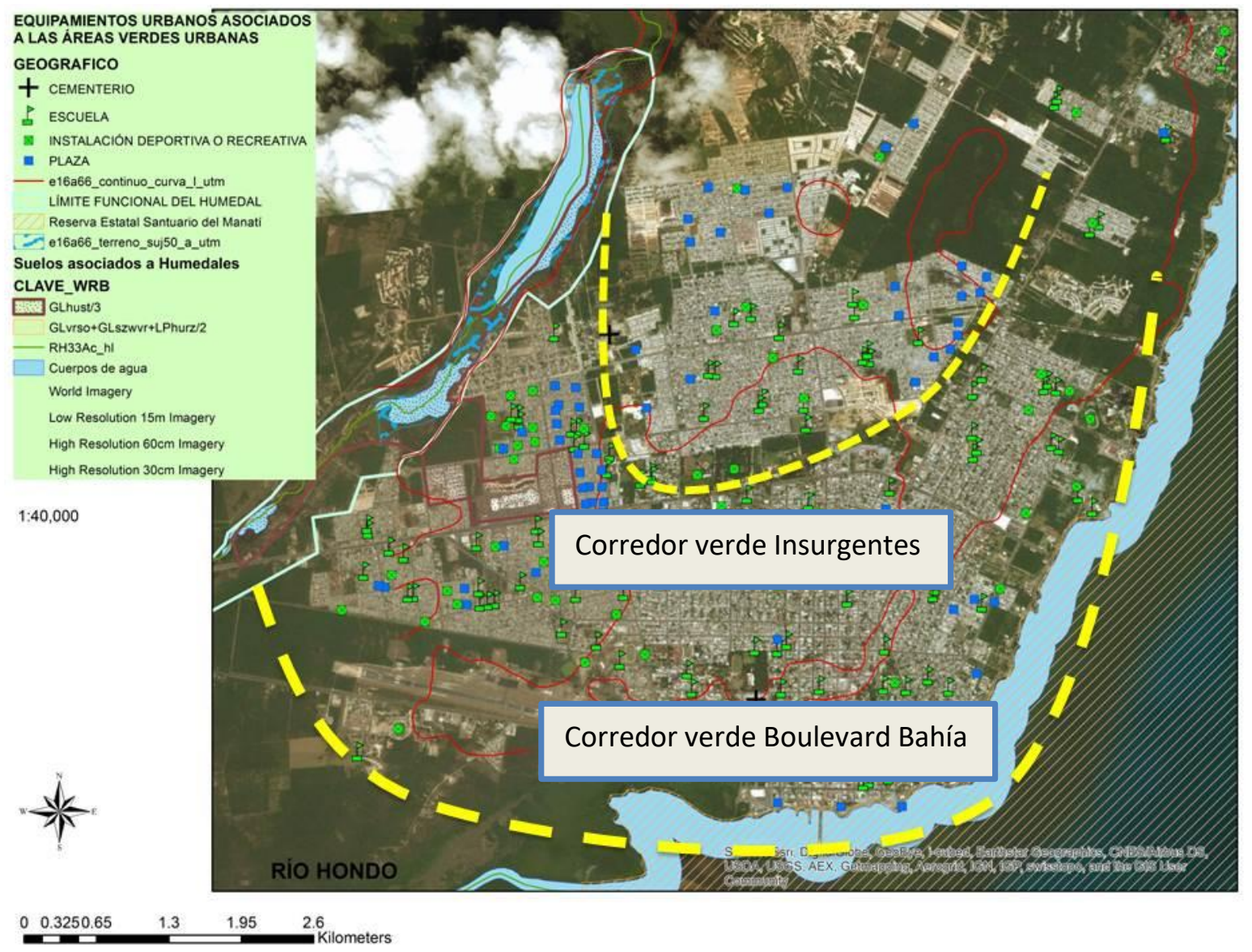

Fuente: Elaboración propia con datos del SCINCE 2010, para Quintana Roo.

Al respecto, el PDU, 2018, señala que Chetumal posee dos centros deportivos que cuentan con gimnasio y piscina, canchas para la práctica de diferentes deportes, el estadio de béisbol Nachan Ka'an, el estadio José López Portillo, el Palacio de los Deportes Erick Paolo Martínez, así como diversos campos deportivos de juegos distribuidos por toda el área urbana, que son de importancia para la población, entre los que se encuentran: Estadio 10 de Abril, Unidad Deportiva Bicentenario, Estadio 20 de 
Noviembre, el Campo Deportivo "La Charca", la Unidad Deportiva Romero Molina; en materia de áreas verdes hay que resaltar la carencia de un gran parque urbano, pero en cambio existen varios parques interiores distribuidos por toda la ciudad, entre los más célebres están el Parque de los Caimanes (en el centro de la ciudad), el Parque de "Las Casitas" (Av. Venustiano Carranza esquina Av. José María Morelos), el Parque Benito Juárez (conocido coloquialmente como Parque del "Queso", en Av. 4 de Marzo con Laguna de Bacalar), el Parque de la Alameda (junto al Palacio Municipal), el Parque Ecológico Zazil, el Parque Renacimiento (junto al Blvd. Bahía), el Parque Cultural El Faro (también en el Blvd. Bahía).

También existe la unidad deportiva del Instituto Tecnológico de Chetumal, que, aunque con escaso acondicionamiento, está abierta al público general; y un club privado con instalaciones deportivas diversas.

El zoológico Payo Obispo (anteriormente llamado "Biouniverzoo"), puede considerarse como el área verde más grande al interior de la ciudad, con una superficie superior a las 11 hectáreas; en cuyas inmediaciones se encuentra otro terreno de grandes dimensiones que corresponde con la unidad deportiva del Instituto Tecnológico de Chetumal, con una superficie poco mayor de 10 hectáreas, y que entre ambos podrían formar el "pulmón" verde más importante al interior de la ciudad, y que además se sitúa casi en concordancia con el centro geométrico de la ciudad ${ }^{44}$, y que coincide con el corredor verde que se señaló en la figura anterior, teniendo así dos corredores principales: el corredor verde Insurgentes, ubicado al centro norte de la ciudad y que une el oriente y el poniente de Chetumal; mientas que al sur se encuentra el corredor verde Boulevard Bahía, que recorre al sur de la ciudad en un magnífico paseo para los chetumaleños.

\subsubsection{Asentamientos Irregulares}

EI PDU, 2018, reporta 14 asentamientos irregulares, de los cuales al menos 4 están relacionados directamente con "La Sabana", dichos asentamientos carecen de los

\footnotetext{
${ }_{44}$ Programa de Desarrollo Urbano de Chetumal, Calderitas, Subteniente López, Huay-Pix y Xul-Ha. Municipio de Othón P. Blanco, 2018.
} 
servicios municipales como drenaje y alcantarillado, lo que redunda en un impacto sobre el humedal, ya que vierten sus aguas servidas directamente en el humedal o en pozos sin el tratamiento adecuado. Por otro lado se fortalece una imagen de degradación al ser viviendas donde prevalecen sistemas constructivos deficientes o precarios. La percepción de inseguridad es de todos conocida en la ciudad de Chetumal.

\section{La Virtud (al poniente de "La Sabana")}

Este asentamiento es resultado de la participación del Movimiento Antorchista ${ }^{45}$, la información que se dispone indica que se ubica en una parcela de tierra situada dentro de tierras de uso común del Ejido Calderitas, acerca de la cual las autoridades ejidales han manifestado anteriormente que la "compra"/ocupación de esta parcela es irregular.

45 El movimiento antorchista se autodenomina como una agrupación social: sus activistas platican con los campesinos y colonos, los reúnen, les explican los propósitos de la organización, tratan de recoger sus problemas y tratan de organizarlos y hacerlos participar en las gestiones, en las luchas en general, encaminadas hacia el beneficio de sus comunidades. Ref:

<http://www.antorchacampesina.org.mx/comotrabajamos.php> 


\section{Figura 32. Mosaico fotográfico de asentamientos cercanos a "La Sabana"}
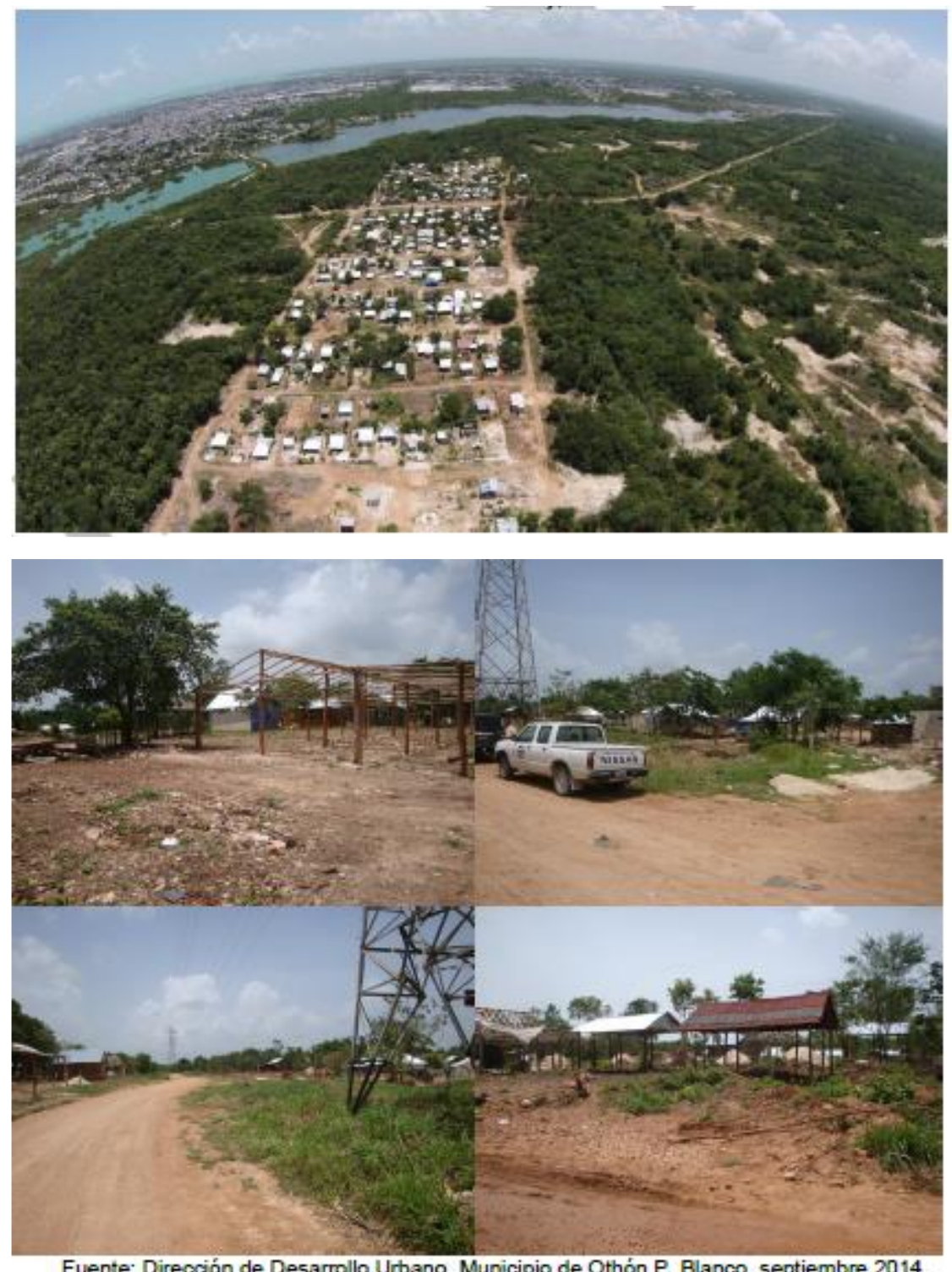

Fuente: Programa de Desarrollo Urbano de Chetumal, Calderitas, Subteniente López, Huay-Pix y Xul-Ha. Municipio de Othón P. Blanco, 2018.

Las visitas de campo realizadas por la Dirección de Desarrollo Urbano del municipio, revelan que, al interior de este asentamiento, topográficamente se observan desniveles notables sobre los que han construido viviendas improvisadas, esto resultado de que anteriormente este terreno fue utilizado como banco de material. 


\section{Figura 33. Asentamiento irregular "La Virtud"}

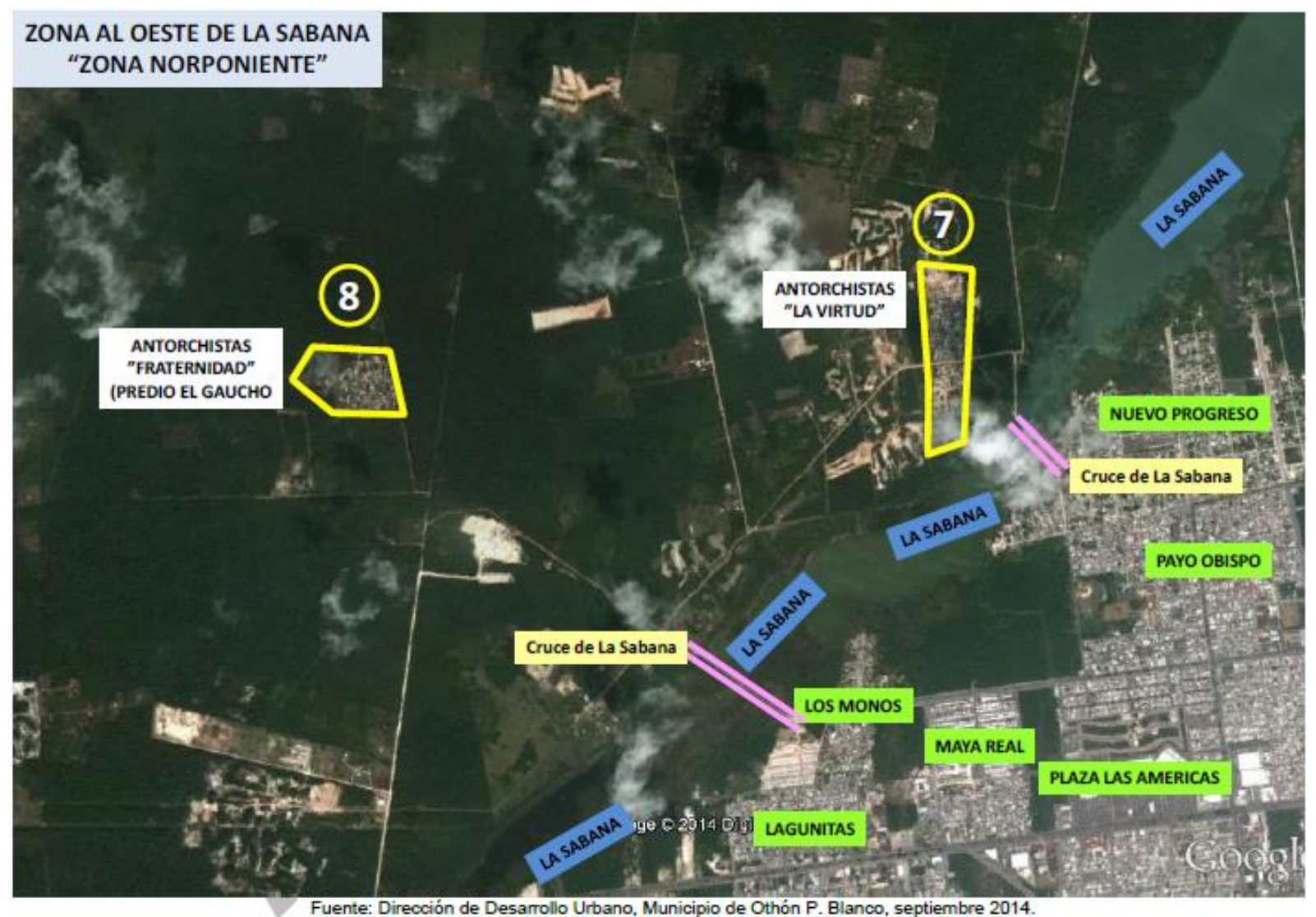

Fuente: Programa de Desarrollo Urbano de Chetumal, Calderitas, Subteniente López, Huay-Pix y Xul-Ha. Municipio de Othón P. Blanco, 2018. 
Figura 34. Asentamiento Irregular "La Franja"

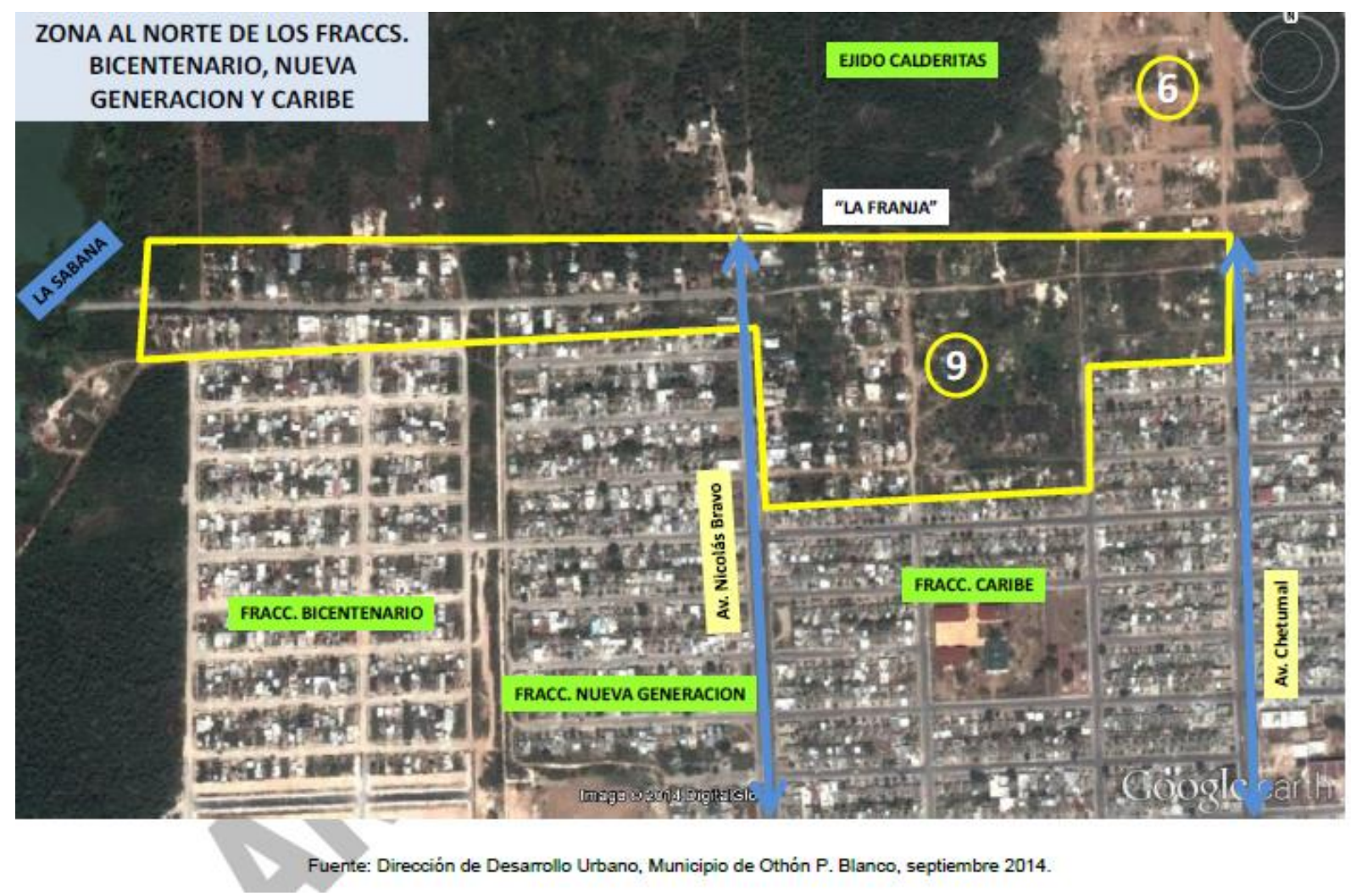

Fuente: Programa de Desarrollo Urbano de Chetumal, Calderitas, Subteniente López, Huay-Pix y Xul-Ha. Municipio de Othón P. Blanco, 2018.

Franja al poniente de la colonia Tamalcab (límites ejidos Chetumal-Calderitas).

Existe una franja al poniente de la colonia Tamalcab con límites imprecisos aledaños a "La Sabana", donde se observa un proceso irregular y paulatino de relleno con escombros producto de los desperdicios de procesos constructivos o a partir de movimientos de terreno para ganar espacio al cuerpo de agua, lo que se conoce como "relleno hormiga". Esta práctica indebida modifica profundamente el funcionamiento natural del cuerpo de agua y provoca inundaciones que representan el mayor factor de vulnerabilidad y riesgo para la zona urbana durante la temporada de lluvias y se agudiza durante el periodo de huracanes. 


\section{Figura 35. Asentamientos irregulares sobre camino que cruza el humedal}
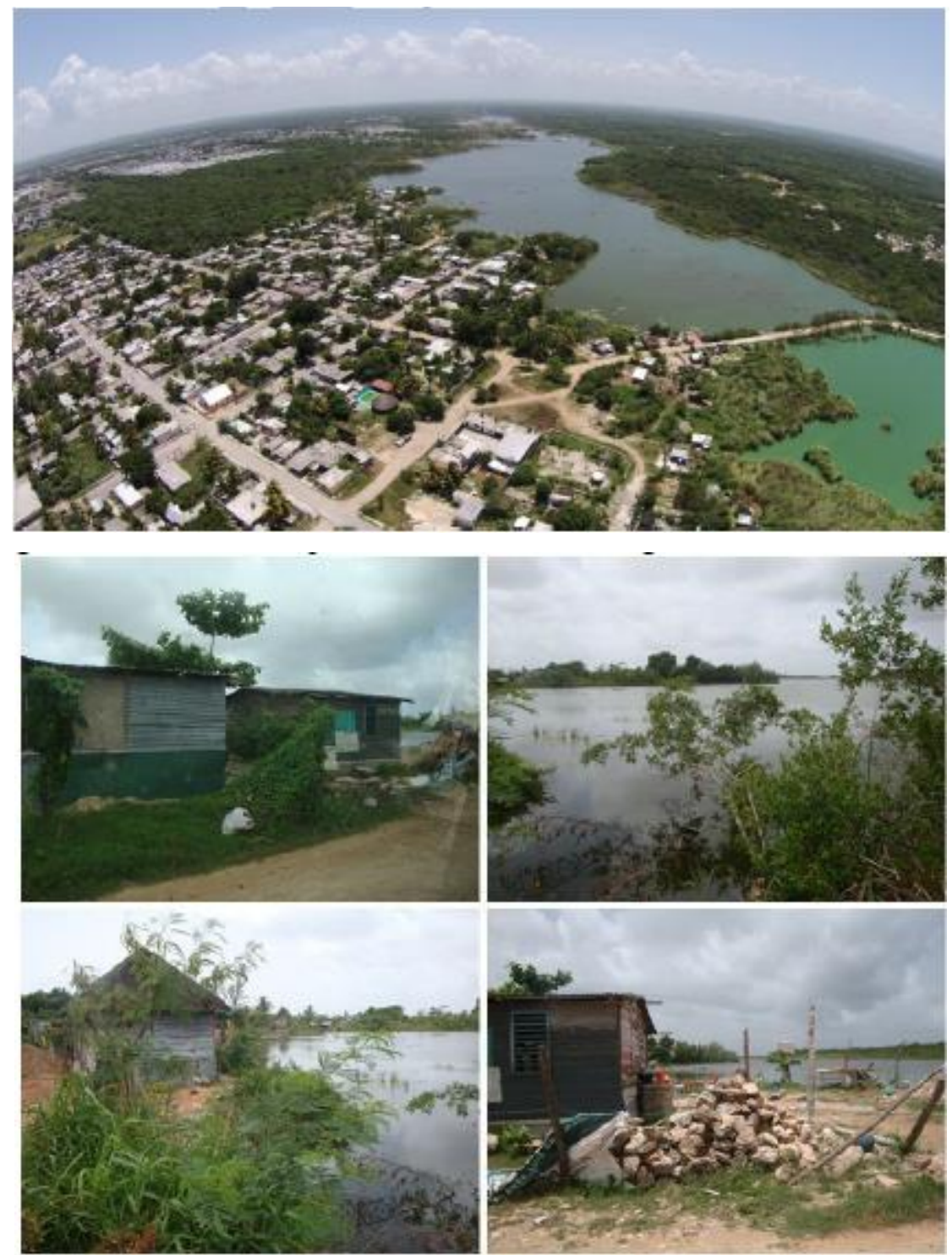

Fuente: Dirección de Desarrollo Urbano, Municipio de Othón P. Blanco, septiembre 2014

Fuente: Programa de Desarrollo Urbano de la Ciudad de Chetumal-Calderitas-Subteniente López-Huay-Pix y Xul-Há. Municipio de Othón P. Blanco, Estado de Quintana Roo, 2018.

Este asentamiento irregular es el más expuesto a peligro de inundación, ya que se trata de terrenos ganados en forma irregular e ilegalmente a la laguna. 
Figura 36. Asentamiento Irregular "Tamalcab" y sobre el paso que cruza "La Sabana"

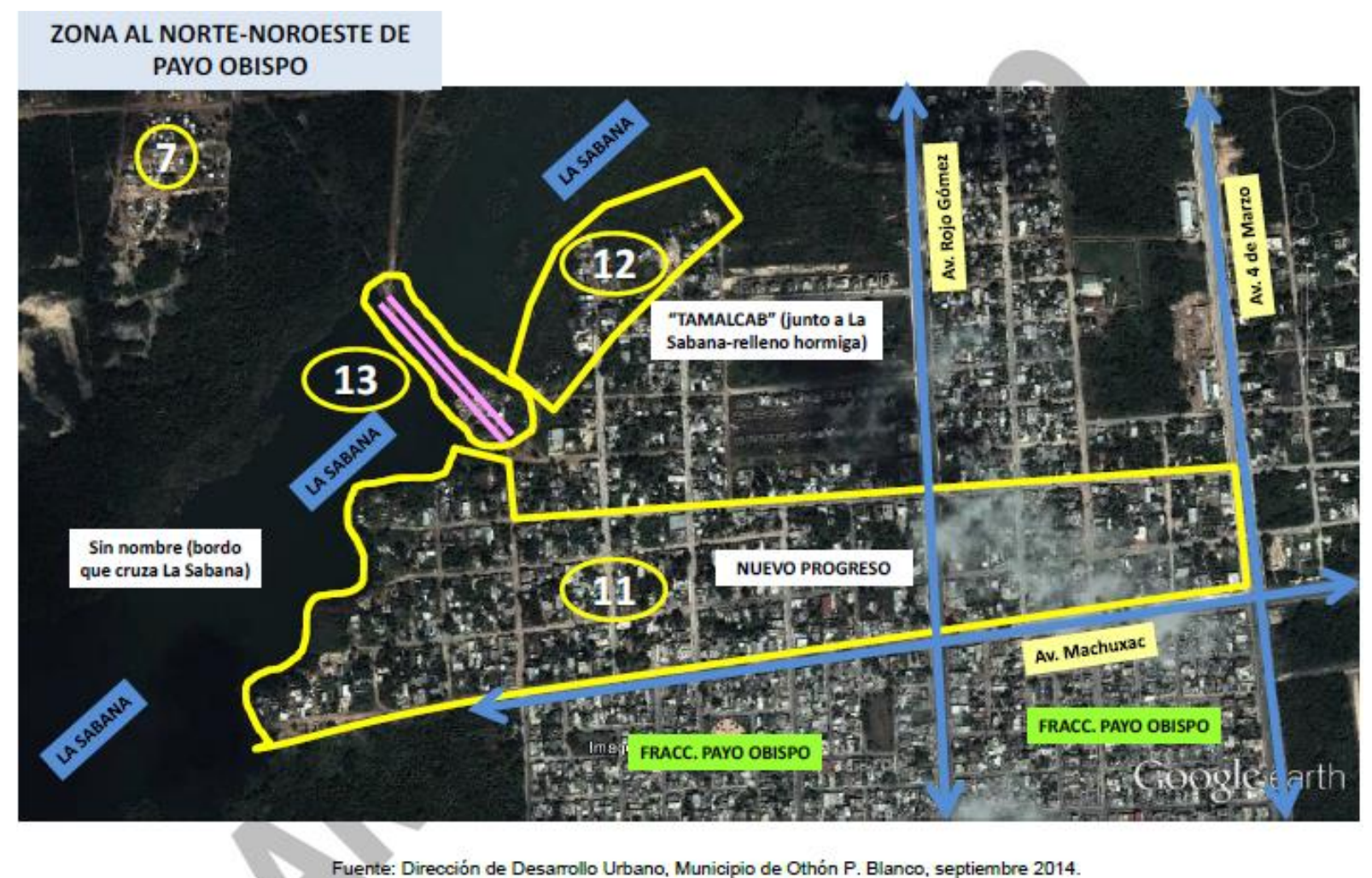

Fuente: Programa de Desarrollo Urbano de Chetumal, Calderitas, Subteniente López, Huay-Pix y Xul-Ha. Municipio de Othón P. Blanco, 2018.

\subsection{EL ENTORNO PAISAJÍSTICO}

\subsubsection{El Barrio como elemento identitario}

Los Barrios, entendidos como unidades socio espaciales, están conformados por los distintos asentamientos que se sucedieron a través del tiempo, de tal forma que su expresión como unicidad radica en el propio reconocimiento de los residentes como parte de su comunidad, como desde fuera por los otros asentamientos; los barrios pueden entenderse de acuerdo a Kevin Lynch (2014) como sectores definidos de la ciudad, con identidad propia. En este sentido es posible reconocerlos por el momento histórico en el que se fueron asentando, la condición de regularidad (asentamientos irregulares), y sus 
características arquitectónicas o consolidación de infraestructuras urbanas, entre otros aspectos.

En este caso encontramos por ejemplo, la autodenominada colonia Mártires Antorchista, tal como señala el letrero en el acceso de este asentamiento.

Figura 37. Auto denominación del asentamiento para generar el sentido de identidad

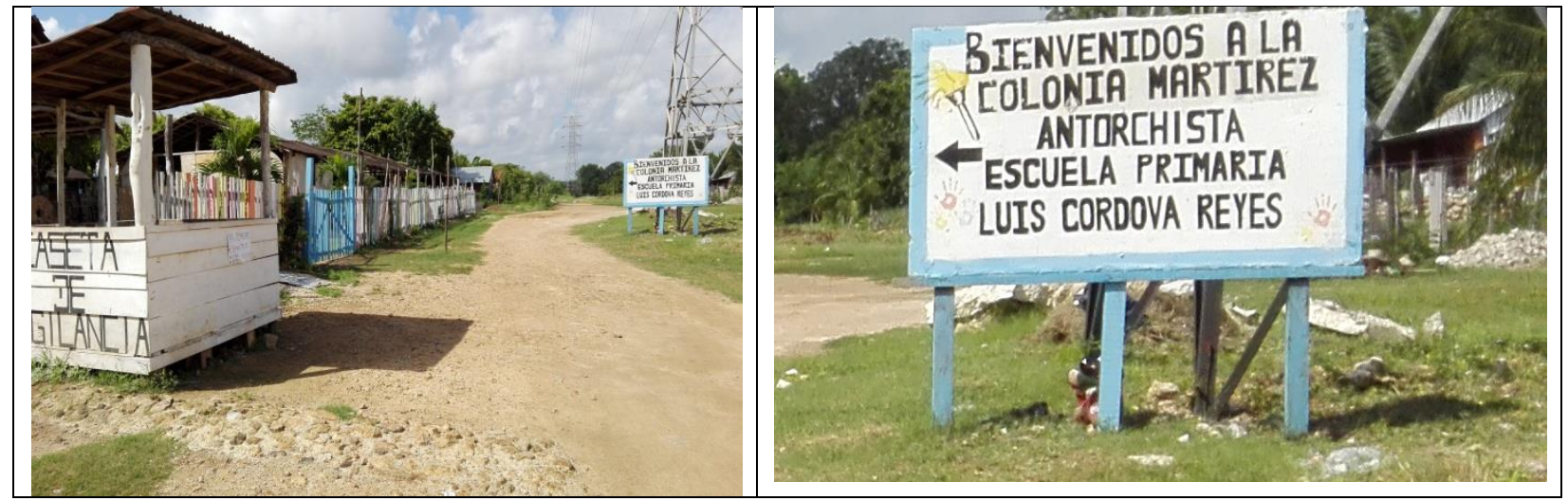

Fuente: Fotografía del autor, 2015.

En las figuras, sobresalen las líneas de alta tensión, predominan calles de terracería, las construcciones se alternan entre sistemas constructivos tradicionales a base de muros de madera y láminas de acero y cartón, y construcciones con muros de block y cubiertas también de láminas. A su vez se aprecia el uso de la vegetación, con una preferencia hacia árboles frutales de coco y plátano. 
Figura 38. Sistemas constructivos tradicionales y en proceso de consolidación

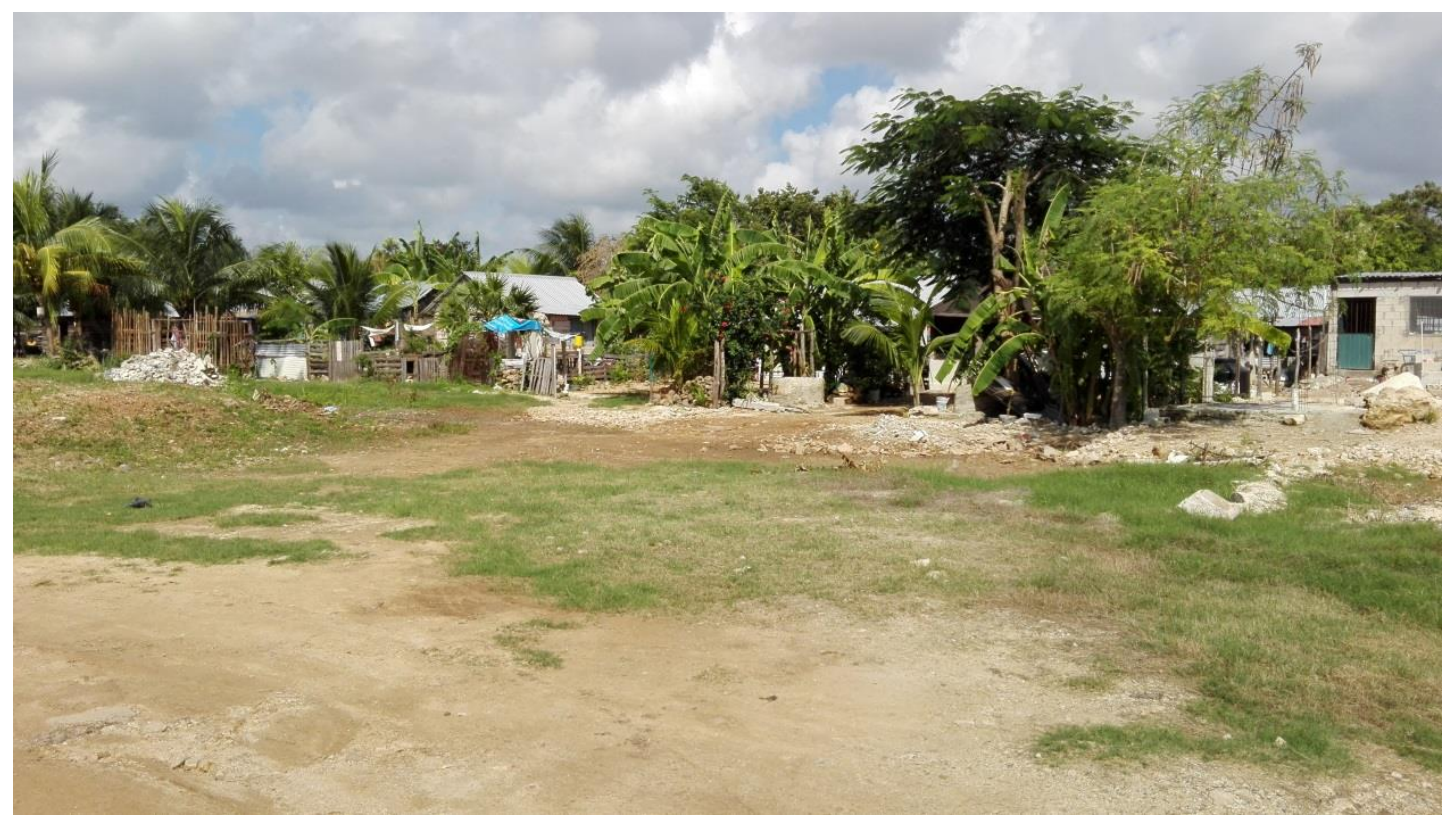

Fuente: Fotografía del autor, 2015.

Por su parte en el entorno inmediato a uno de los caminos que atraviesan el humedal, las características de la vivienda son más precarias, en espacios que fueron rellenados para ganarle terreno a "La Sabana". Conforme se acercan las viviendas al humedal, el nivel de precariedad aumenta. En este sitio encontramos viviendas con muros de madera, cartón y lámina. El punto de referencia inmediato es el camino de terracería que cruza el humedal.

Figura 39. Mosaico fotográfico sobre camino "Norte" que atraviesa el humedal

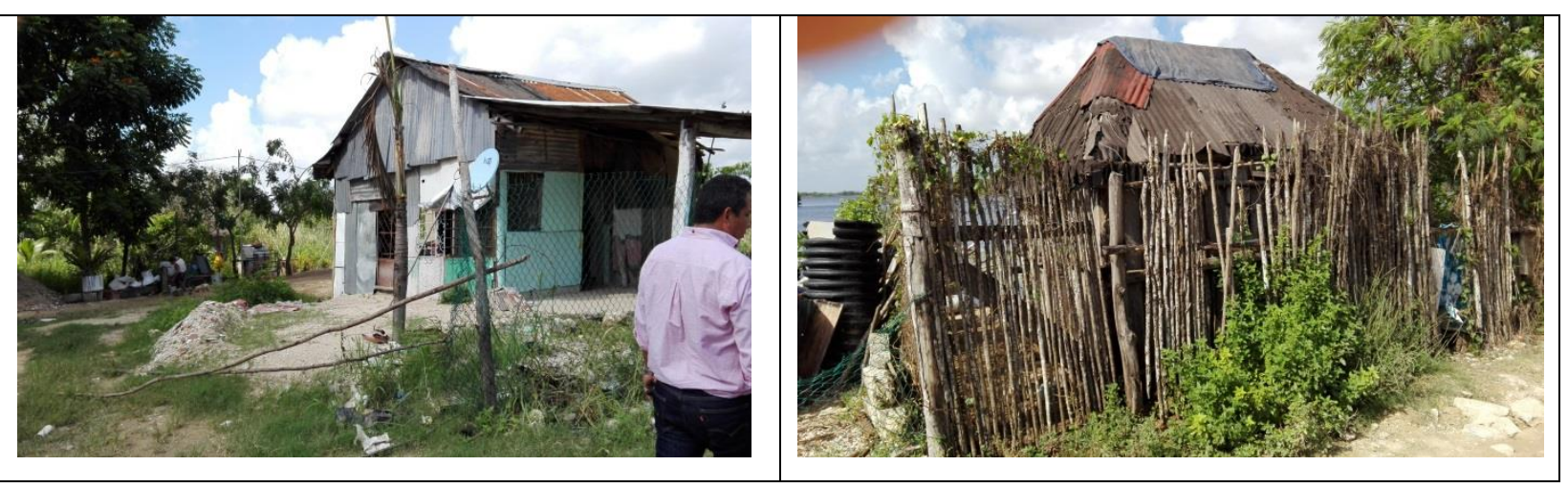



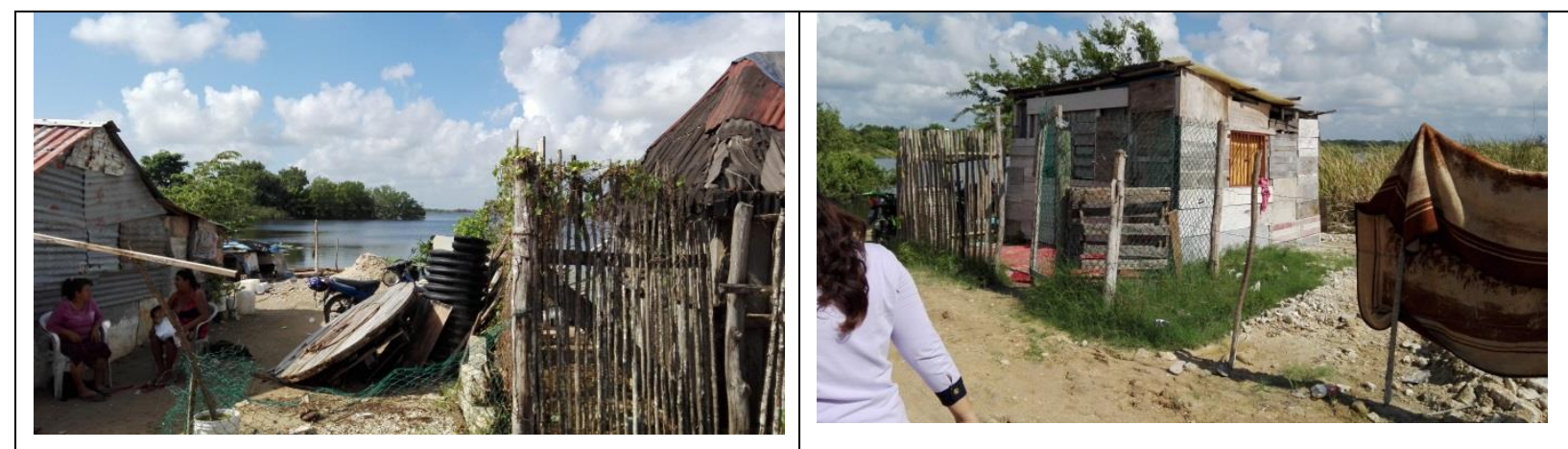

Fuente: Fotografías del autor, 2015.

Por otro lado, podemos observar que existen diferentes formas de relacionarse con el humedal, hay viviendas que prácticamente dan la espalda al humedal (fig. 40, izquierda), mientras que existen ejemplos notables de terrenos que fueron pensados para integrarse y disfrutar del paisaje natural de "La Sabana" (figura 40, derecha).

\section{Figura 40. Configuración espacial por la relación humedal-terrenos}

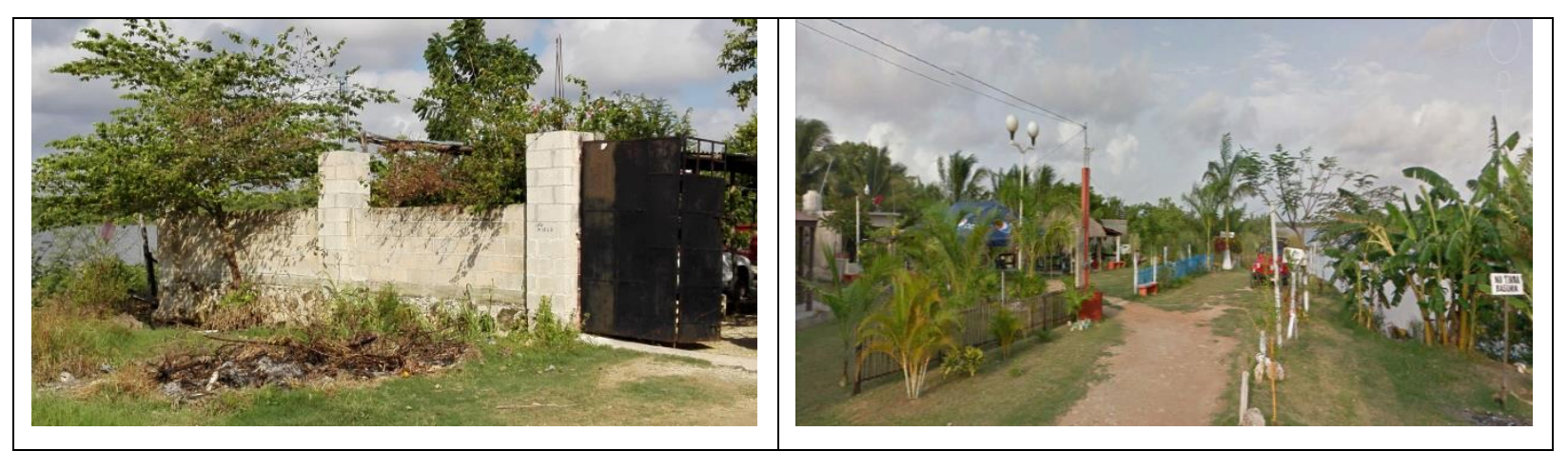

Fuente: izquierda: fotografía del autor, 2015; derecha: google earth, 2017.

\subsubsection{Visuales, nodos y puntos de encuentro}

Por su parte los caminos que confluyen en el humedal pueden convertirse en ventanas 0 recorridos que permiten apreciar el valor paisajístico de "La Sabana", al tiempo que denotan un carácter utilitario ya que facilitan la comunicación terrestre de la zona, con el resto del área urbana de Chetumal; sin embargo estas vías se construyeron rellenando el humedal sin las características adecuadas de drenaje lo que ocasionó el deteriorio del 
flujo natural hídrico provocando inundaciones, anegamiento de agua, presencia de mosquitos, entre otros.

Figura 41. Ventanas al Paisaje "Sur"

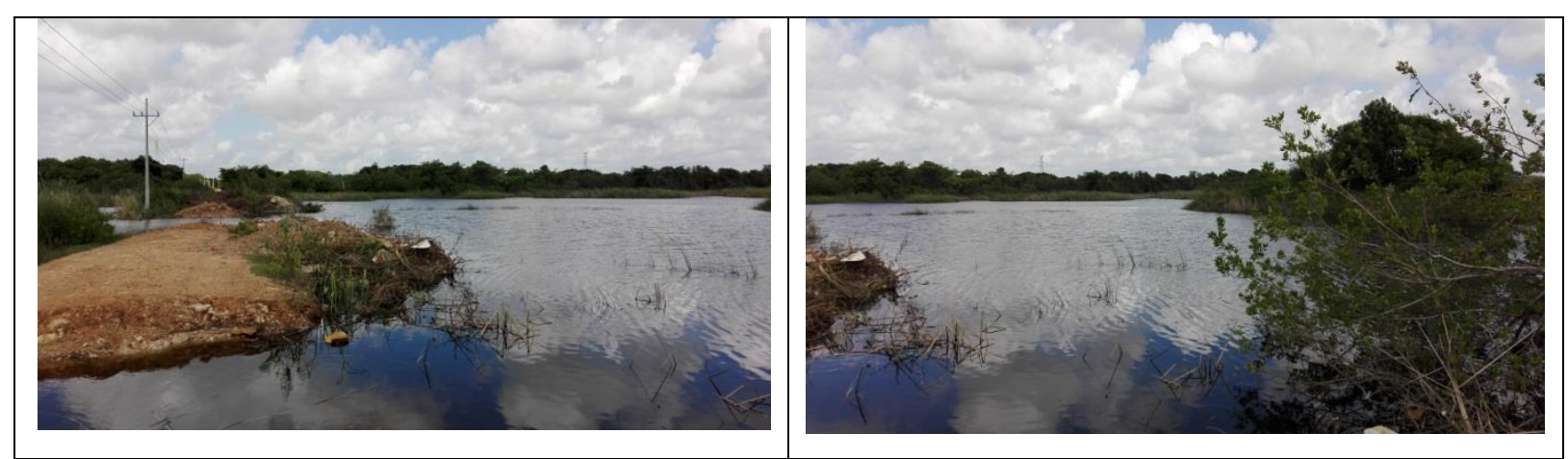

Fuente: Fotografías del autor.

Hay que reconocer la oportunidad que brindan estos caminos para apreciar el paisaje del humedal.

Figura 42. Ventana al paisaje "Centro", continuación Av. Maxuxac

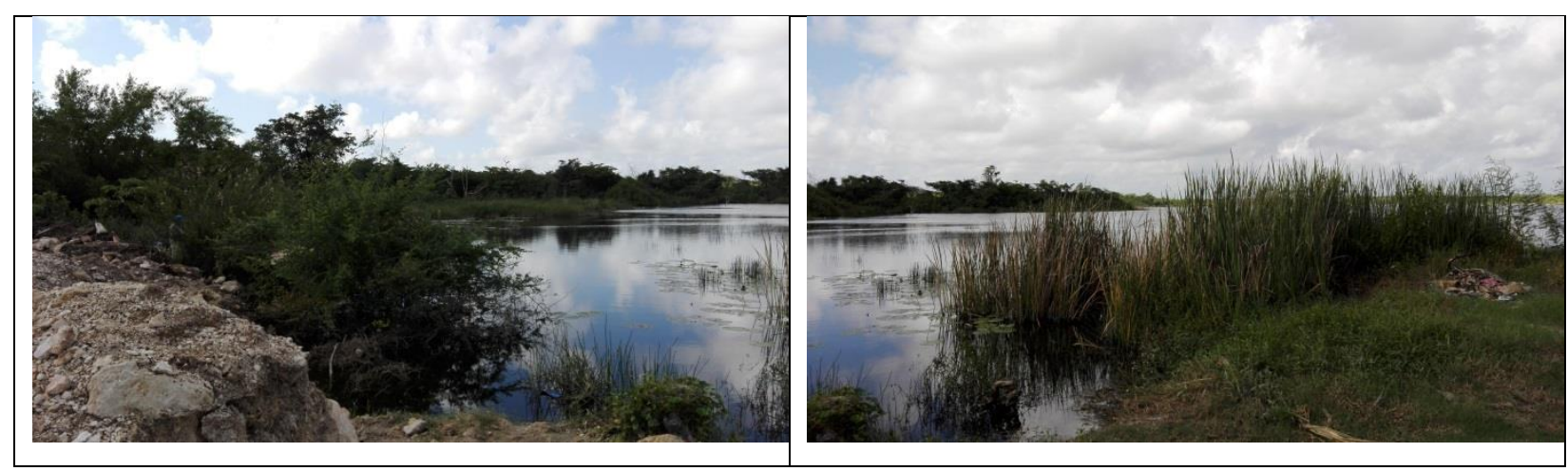

Fuente: Fotografías del autor 
Figura 43. Ventanas al Paisaje "Norte"

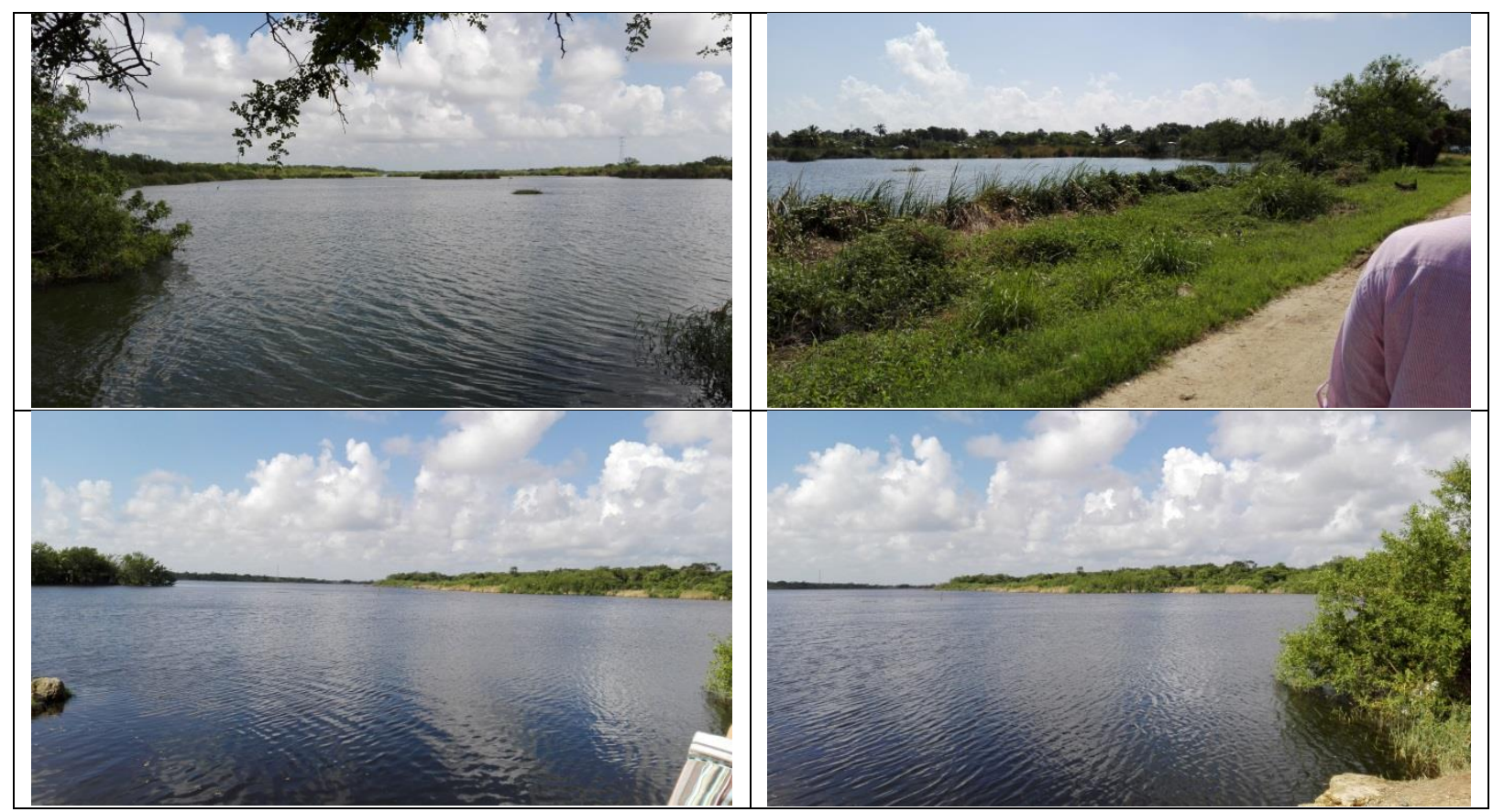

Fuente: Fotografías del autor.

En "La Sabana", los propios caminos se convierten en puntos de encuentro donde la gente se relaciona con el humedal, llevando a cabo no solo actividades de tránsito, sino también de esparcimiento, recreativas, y de apoyo a la economía familiar como pesca para el autoconsumo.

Figura 44. Mosaico: Los caminos como puntos de encuentro

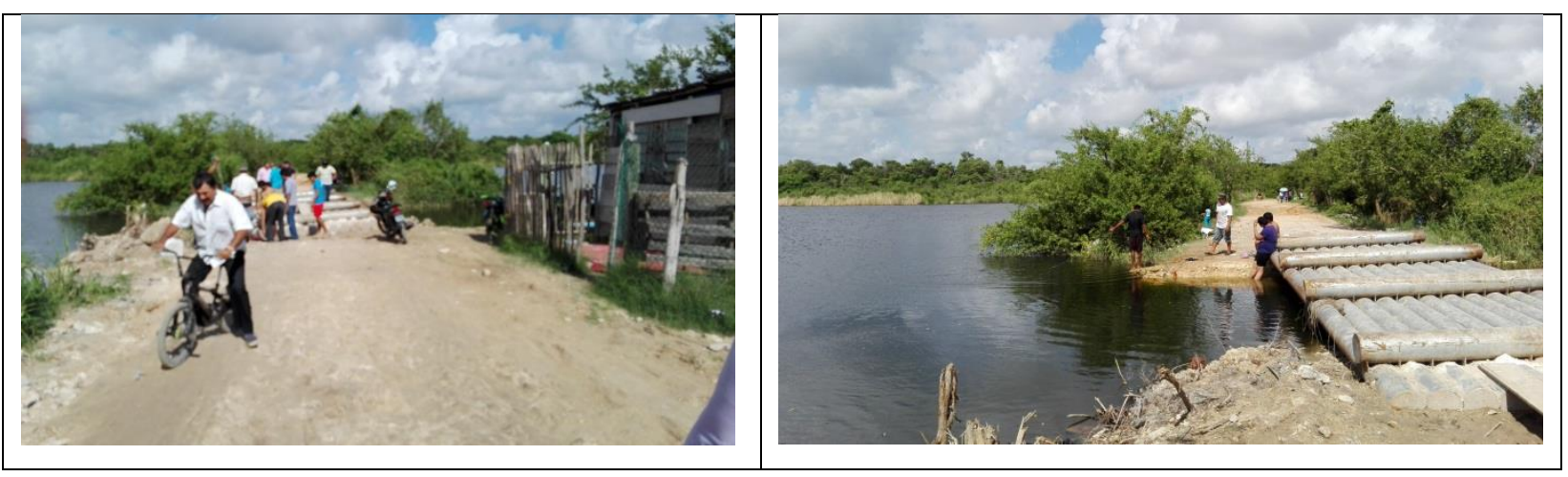



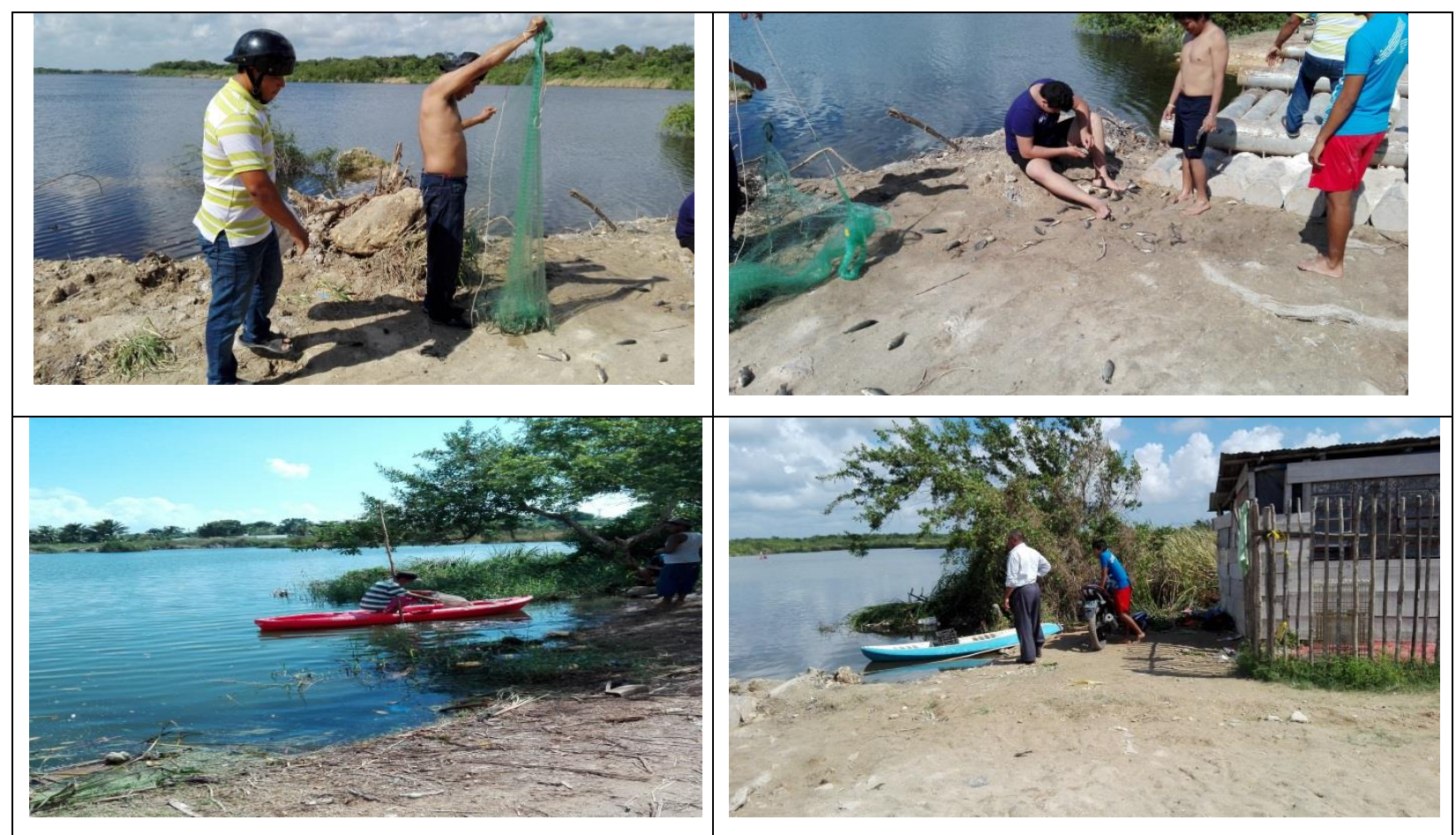

Fuente: Fotografías del autor, 2015.

La siguiente figura 45, señala espacialmente los nodos como puntos de encuentro, las visuales y el origen de las visuales actuales hacia el paisaje del humedal y la selva en derredor. 
Figura 45. Visuales, puntos focales y nodos de encuentro social del humedal "La Sabana"

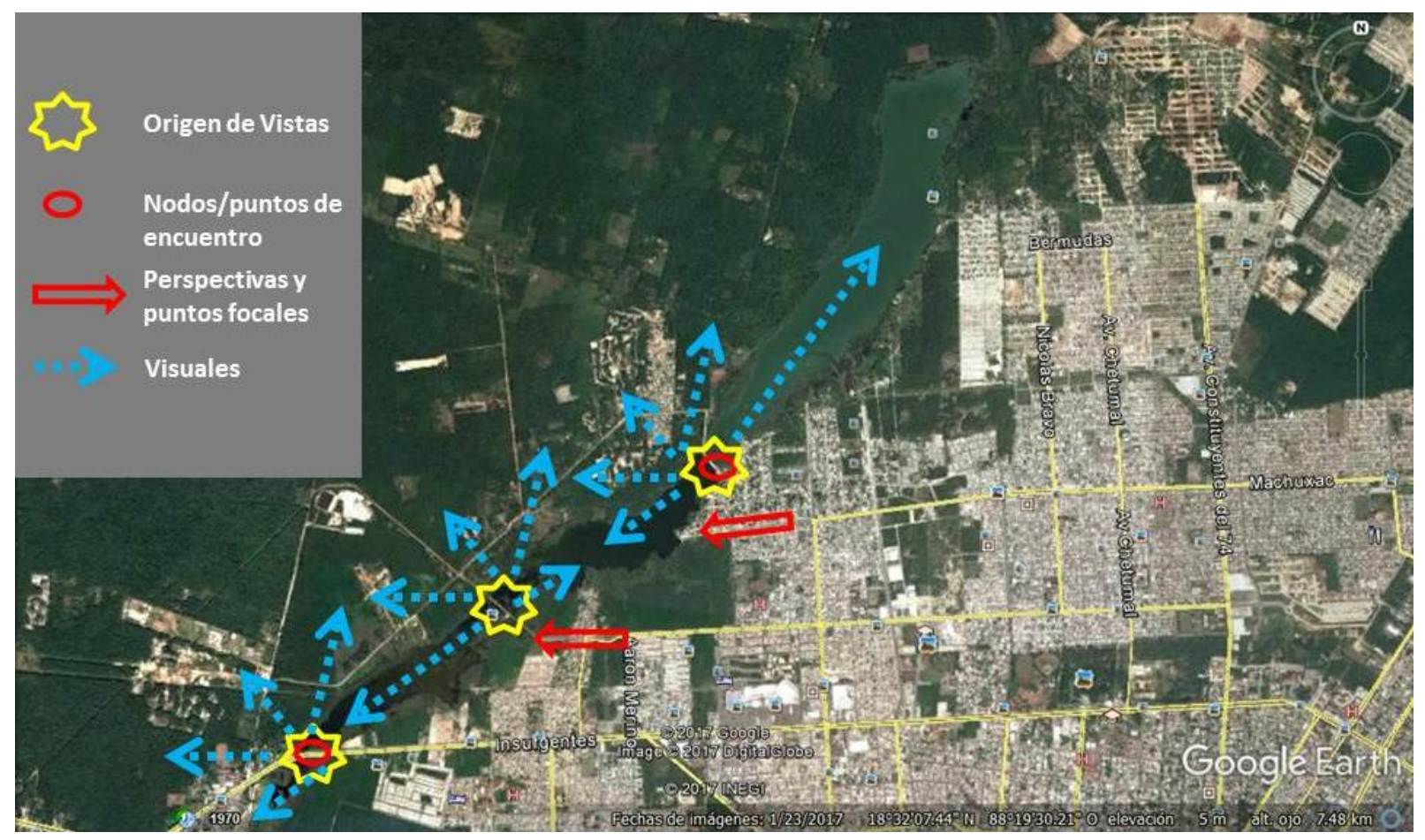

Fuente: Elaboración propia. Imagen de Google earth, 2017.

\subsubsection{Percepción social del entorno y su relación con el humedal}

Con el propósito de conocer la valoración social del humedal, se realizó una serie de cuestionarios abiertos al público en general, consistentes en calificar una serie de fotografías de los paisajes lacustres más representativos del municipio de Othón $P$. Blanco, en donde se incluyeron fotos de "La Sabana", los resultados se presentaron en el XVI Congreso internacional y XXII Congreso nacional de Ciencias Ambientales, dado en la Universidad de Quintana Roo en 2017, quedando de manifiesto que la valoración social hacia el humedal era baja. 
Con relación a lo anterior, es importante señalar que dicha valoración o el método para valorar el paisaje es de carácter cualitativo, ya que toma en cuenta la calificación de los paisajes a partir de la contemplación de los mismos representados en fotografías. Para ello se recurre a la aplicación aleatoria de cuestionarios a personas con diferente perfil etario, socioeconómico y educativo con el objeto de conocer la percepción y valoración que tiene de ellos. Paralelamente se llevó a cabo un Análisis de Calidad Visual, el cual consistió en valorar en una escala de uno a cinco, un grupo de 8 fotografías, según la belleza escénica que representó para el encuestado de acuerdo al agrado visual que le provocó observar las fotografías de referencia. Cabe resaltar que no se incluyó ningún tipo de criterio adicional para valorar cada paisaje (Ver anexos).

Los resultados fueron variables, aunque hubo una preferencia marcada hacia los lugares de belleza natural, pero con las comodidades para su disfrute, con la consecuente antropización; así, mientras que unos prefieren paisajes naturales, otros lo hacen con los culturales, incluso haciendo señalamientos como el ambiente de tranquilidad de la ciudad de Chetumal.

Como parte de los resultados, también se aprecia una preferencia hacia las zonas turísticas de sol, playa y lagunas, el boulevard bahía y la Bahía de Chetumal. En general hubo una gran preferencia por las lagunas y cenotes de colores azules turquesas y transparentes, en donde existe presencia de infraestructuras turísticas para el descanso y el recreo. Por otro lado, hubo menos predilección por los Ríos, y los cuerpos de agua con colores más oscuros y con menor presencia antrópica y posiblemente con mayor calidad ecológica. Sin que podamos determinar (en este caso) si se debe a cuestiones de accesibilidad, distancias, cuestiones ambientales o ecológicas; o inclusive a la percepción romántica de estos lugares, propiciada por la industria turística, que ha infundido la idea de que estos lugares se comparan con el paraíso, puede ser una cuestión mercadotécnica. 


\section{ENTORNO SOCIAL, CARACTERIZACIÓN SOCIODEMOGRÁFICA}

\subsubsection{Grado de marginación urbana}

De acuerdo a la CONAPO (2009) el índice de marginación urbana, es una medida resumen que permite diferenciar a las áreas geoestadísticas básicas (AGEB) urbanas ${ }^{46}$ del país, según el impacto global de las privaciones que padece la población como resultado de la falta de acceso a la educación y la salud, la residencia en viviendas inadecuadas y la carencia de bienes de primera necesidad. Para su estimación se utilizó como fuente de información la base de microdatos del II Conteo de Población y Vivienda 2005, proporcionada por el Instituto Nacional de Estadística y Geografía.

Los resultados del índice permiten afirmar que, en el ámbito urbano, México también se caracteriza por una amplia desigualdad en la participación del proceso de desarrollo y el disfrute de sus beneficios. La mayor intensidad de la marginación se presenta en un total de 8,557 AGEB del sistema urbano nacional con alto y muy alto grado de marginación, donde el nivel de las carencias sociales limita las oportunidades de desarrollo y la calidad de vida de 14.6 millones de personas, quienes representan 21 por ciento de la población urbana total, distribuidas de manera sumamente heterogénea entre las 358 ciudades del país (CONAPO, 2009).

Las disparidades regionales en la incidencia de la marginación urbana ponen de manifiesto la importancia de fortalecer los programas de desarrollo social orientados a mejorar el hábitat de la población urbana que reside en zonas con alto y muy alto grado de marginación, y a promover una oferta de suelo, vivienda y servicios básicos accesible a la población de menores ingresos, que contribuya al crecimiento equitativo, ordenado y sustentable de las ciudades y centros de población (CONAPO, 2009).

\footnotetext{
${ }^{46}$ Área geográfica ocupada por un conjunto de manzanas que generalmente son de 1 a 50, perfectamente delimitadas por calles, avenidas, andadores o cualquier otro rasgo de fácil identificación en el terreno y cuyo uso del suelo sea principalmente habitacional, industrial, de servicios, comercial, etcétera. (Instituto Nacional de Estadística, Geografía e Informática, Manual de Cartografía Censal. II Conteo de Población y Vivienda 2005).
} 
La siguiente figura, expresa espacialmente el Grado de Marginación por AGEB urbana, para la ciudad de Chetumal en 2005. Como puede observarse las Áreas que colindan con el humedal, y que se localizan en la periferia de la ciudad, cuentan con Altos y Muy Altos Grados de Marginación.

"Esta población, que por lo general se asienta de manera irregular en la periferia de las ciudades, en zonas no aptas para el desarrollo urbano, enfrenta una serie de riesgos y vulnerabilidades que comprometen su calidad de vida, así como su integridad física y la de su patrimonio; con efectos también negativos sobre el medio ambiente (deterioro ecológico y contaminación), que a su vez repercuten en la salud y seguridad de la población" (CONAPO, 2009).

Figura 46. Chetumal, Grado de Marginación por AGEB Urbana, 2005.

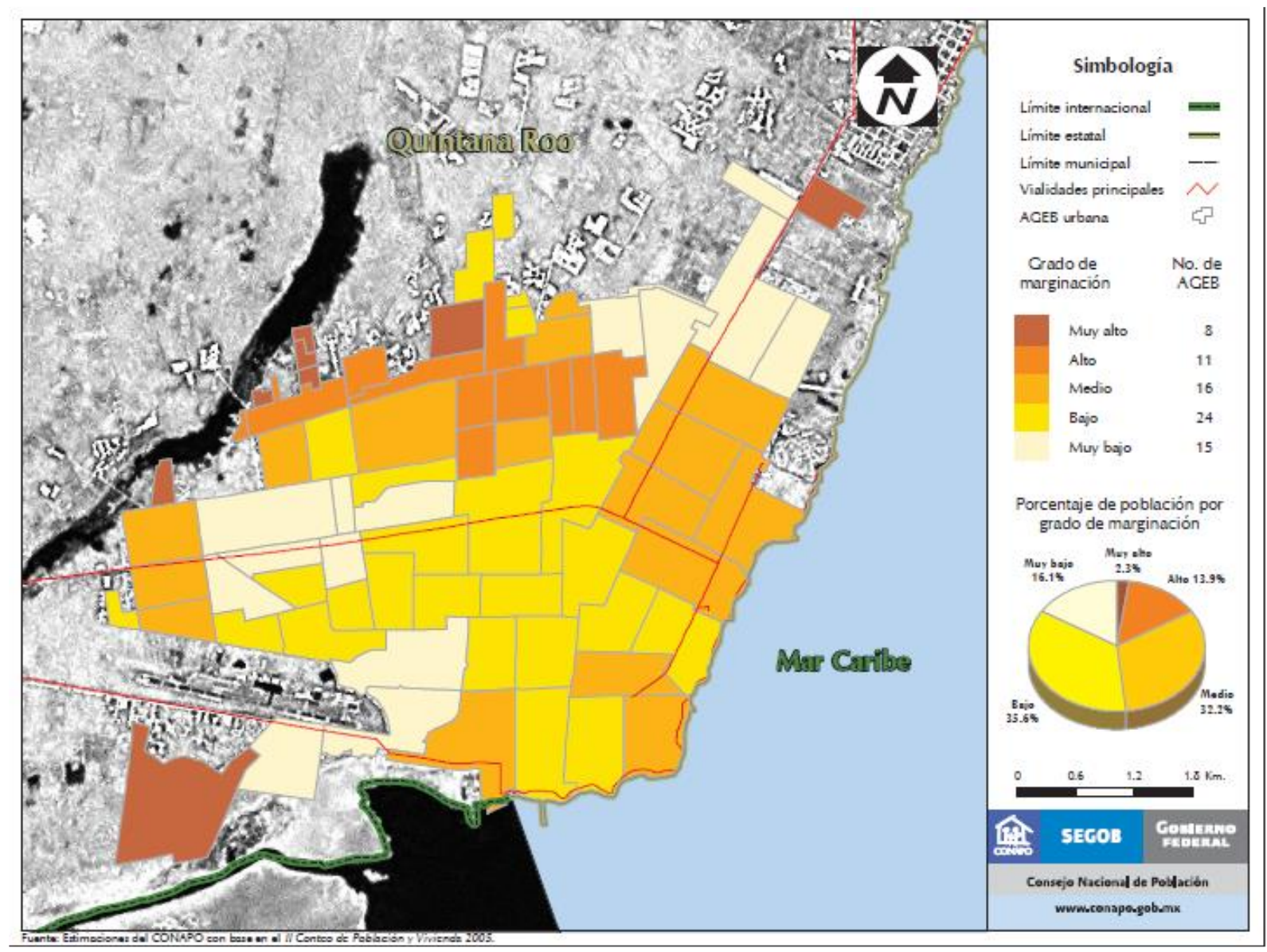


Fuente: CONAPO, 2009. Índice de marginación urbana 2005

En la tabla siguiente se muestran las cuatro dimensiones y los diez indicadores socioeconómicos que sintetiza el índice de marginación urbana, los cuales miden la intensidad de la exclusión como porcentaje de la población que no participa en el disfrute de bienes y servicios esenciales para el desarrollo de sus capacidades básicas.

Tabla 3. Dimensiones e indicadores del índice de marginación urbana 2005

\begin{tabular}{|c|c|}
\hline Dimensión & Indicador \\
\hline Educación & $\begin{array}{l}\text { Porcentaje de población de } 6 \text { a } 14 \text { años que no asiste a la escuela }\left(l_{1}\right) \\
\text { Porcentaje de población de } 15 \text { años o más sin secundaria completa }\left(l_{2}\right)\end{array}$ \\
\hline Salud & $\begin{array}{l}\text { Porcentaje de población sin derechohabiencia a los servicios de salud }\left(I_{3}\right) \\
\text { Porcentaje de hijos fal lecidos de las mujeres de } 15 \text { a } 49 \text { años }\left(I_{4}\right)\end{array}$ \\
\hline Vivienda & $\begin{array}{l}\text { Porcentaje de viviendas particulares sin agua entubada dentro de la vivienda }\left(I_{5}\right) \\
\text { Porcentaje de viviendas particulares sin drenaje conectado a la red pública o fosa séptica }\left(I_{6}\right) \\
\text { Porcentaje de viviendas particulares sin excusado con conexión de agua }\left(I_{7}\right) \\
\text { Porcentaje de viviendas particulares con pisos de tierra }\left(I_{8}\right) \\
\text { Porcentaje de viviendas particulares con al gún nivel de hacinamiento }\left(I_{9}\right)\end{array}$ \\
\hline Bienes & Porcentaje de viviendas particuares sin refrigerador $\left(I_{10}\right)$ \\
\hline
\end{tabular}

Fuente: CONAPO, 2009. Índice de marginación urbana 2005

Por su parte este mismo indicador para el año 2010, nos muestra que las AGEB que colindan con el humedal tienen un valor de Alto y Medios Grados de Marginación Urbana (figura siguiente). 
Figura 47. Chetumal, Grado de Marginación Urbana por AGEB, 2010.

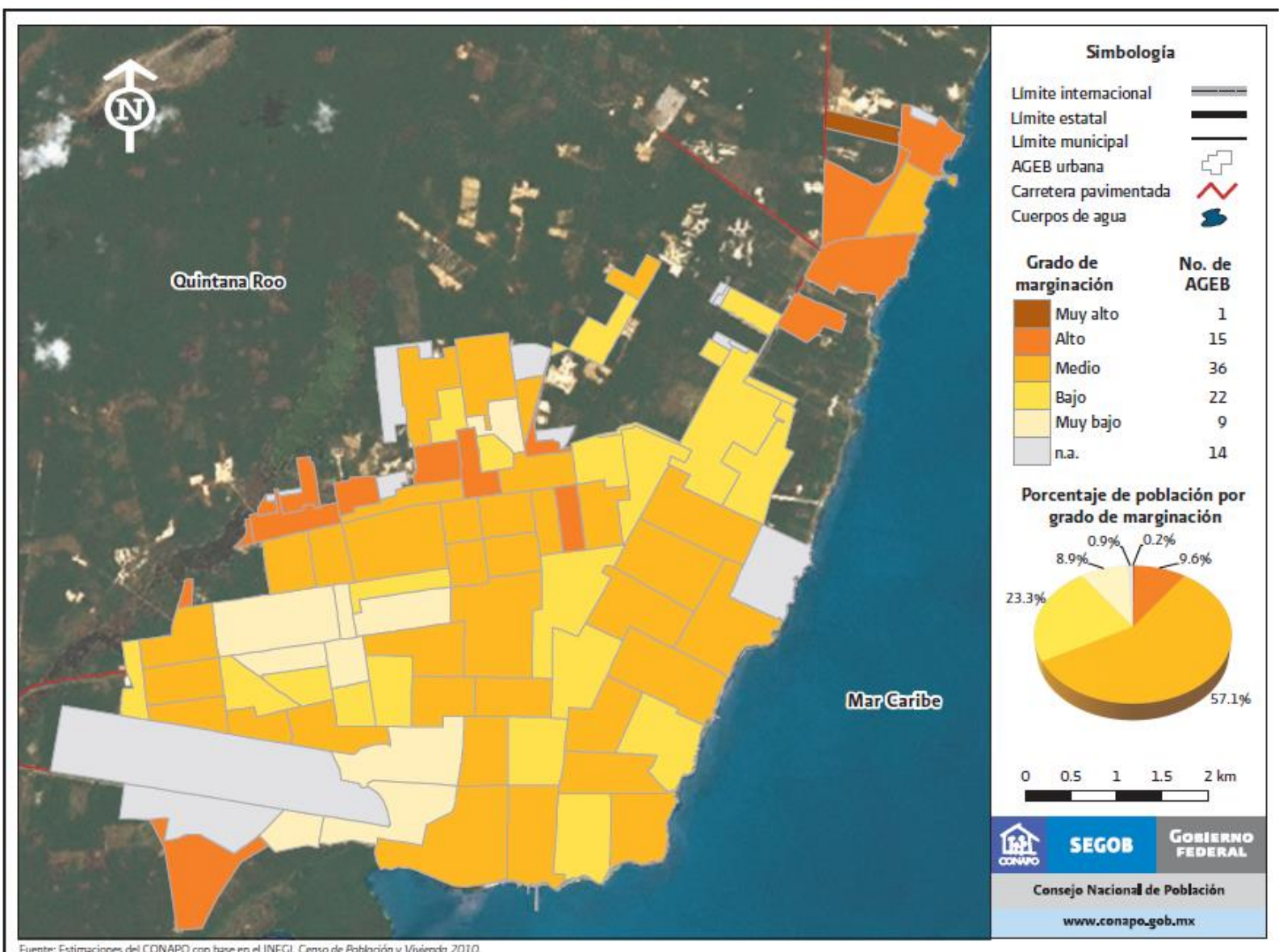

Fuente: CONAPO. Índice de marginación urbana 2010.

El Grado de Marginación por AGEB Urbana, nos muestra que en la zona de estudio existen Altos y Medios grados de marginación, para el 2010, dados por las carencias descritas y una baja calidad de vida de la población. 
Figura 48. Grado de Marginación por AGEB Urbana, en "La Sabana", 2010

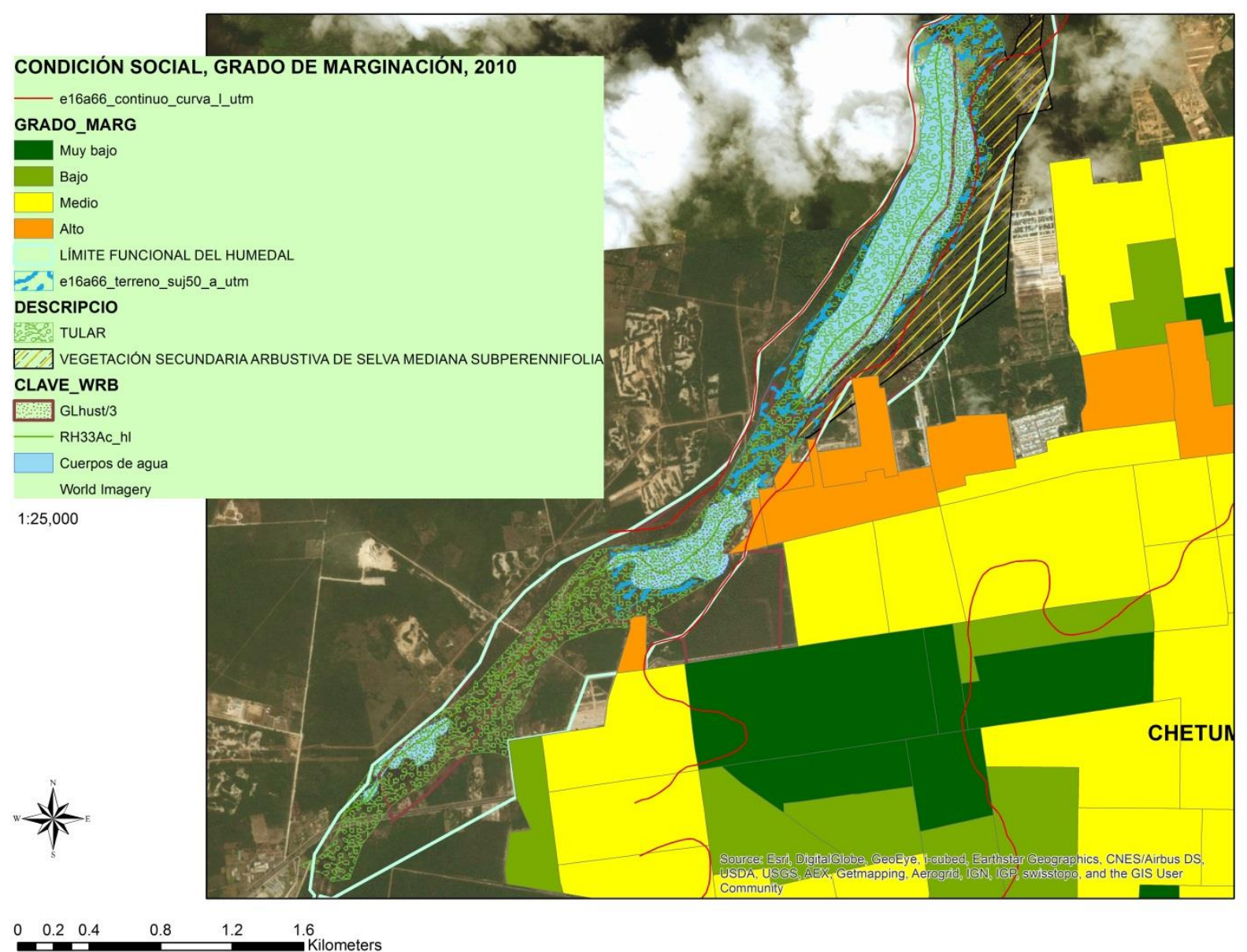

Fuente: Elaboración propia con datos del SCINCE 2010, para Quintana Roo, por AGEB Urbana.

\subsection{ASPECTOS NORMATIVOS APLICABLES}

En el marco internacional destaca la Convención relativa a los humedales de importancia internacional, especialmente como hábitat de aves acuáticas, 1971; RAMSAR es el más antiguo de los modernos acuerdos intergubernamentales sobre el medio ambiente. El tratado se negoció en el decenio de 1960 entre países y organizaciones no gubernamentales preocupados por la creciente pérdida y degradación de los hábitats de humedales para las aves acuáticas migratorias. Se adoptó en la ciudad iraní de Ramsar 
en 1971 y entró en vigor en 197547. La misión de la Convención es "...la conservación y el uso racional de los humedales mediante acciones locales y nacionales y gracias a la cooperación internacional, como contribución al logro de un desarrollo sostenible en todo el mundo".

Al asumir los compromisos contenidos en la Convención Ramsar, a través de su ratificación en 1986, México comprende que los humedales constituyen un recurso de gran valor económico, cultural, científico y recreativo, cuya pérdida sería irreparable ${ }^{48}$.

Por su parte en el Marco Nacional, la Constitución Política de los Estados Unidos Mexicanos establece en el Artículo 88, que para el aprovechamiento sustentable del agua y los ecosistemas acuáticos se considerarán los siguientes criterios:

I. Corresponde al Estado y a la sociedad la protección de los ecosistemas acuáticos y del equilibrio de los elementos naturales que intervienen en el ciclo hidrológico.

II. El aprovechamiento sustentable de los recursos naturales que comprenden los ecosistemas acuáticos deben realizarse de manera que no se afecte su equilibrio ecológico;

III. Para mantener la integridad y el equilibrio de los elementos naturales que intervienen en el ciclo hidrológico, se deberá considerar la protección de suelos y áreas boscosas y selváticas y el mantenimiento de caudales básicos de las corrientes de agua, y la capacidad de recarga de los acuíferos, y

IV. la preservación y el aprovechamiento sustentable del agua, así como de los ecosistemas acuáticos es responsabilidad de usuarios, así

\footnotetext{
${ }^{47} \mathrm{http}: / /$ www.ramsar.org/es/acerca-de/historia-de-la-convencion-de-ramsar fecha de consulta: 13 de Noviembre de 2017.

${ }^{48}$ https://www.dof.gob.mx/nota detalle.php?codigo=4808616\&fecha=29/08/1986 fecha de consulta: 27 de agosto de 2021
} 
como de quienes realicen obras o actividades que afecten dichos recursos.

Entre las normas federales, destaca la Ley General del Equilibrio Ecológico y la Protección al Ambiente (LGEEPA), la cual establece que la Federación, los Estados, el Distrito Federal y los Municipios ejercerán sus atribuciones en materia de preservación y restauración del equilibrio ecológico y la protección al ambiente, de conformidad con la distribución de competencias prevista en esta Ley y en otros ordenamientos legales; sin establecer los criterios que determinan dichas competencias, aunque si faculta a los Estados y municipios a hacer lo propio en la materia.Sin embargo en el artículo 11, se establece que la Federación, por conducto de la Secretaría, podrá suscribir convenios o acuerdos de coordinación, con el objeto de que los gobiernos del Distrito Federal o de los Estados, con la participación, en su caso, de sus Municipios, asuman las siguientes facultades, en el ámbito de su jurisdicción territorial: h) Obras y actividades en humedales, manglares, lagunas, ríos, lagos y esteros conectados con el mar, así como en sus litorales o zonas federales. Así mismo el artículo 46 referente a los tipos y características de las Áreas Naturales Protegidas, establece que se consideran áreas naturales protegidas:

I.- Reservas de la biosfera;

III.- Parques nacionales;

IV.- Monumentos naturales;

VI.- Áreas de protección de recursos naturales;

VII.- Áreas de protección de flora y fauna;

VIII.- Santuarios;

IX.- Parques y Reservas Estatales, así como las demás categorías que establezcan las legislaciones locales;

X.- Zonas de conservación ecológica municipales, así como las demás categorías que establezcan las legislaciones locales, y

XI.- Áreas destinadas voluntariamente a la conservación. 
De los cuales son competencia de la Federación las áreas naturales protegidas comprendidas en las fracciones I a VIII y XI.

Los Gobiernos de los Estados y del Distrito Federal, en los términos que señale la legislación local en la materia, podrán establecer parques, reservas estatales y demás categorías de manejo que establezca la legislación local en la materia, ya sea que reúnan alguna de las características señaladas en las fracciones I a VIII y XI del presente artículo o que tengan características propias de acuerdo a las particularidades de cada entidad federativa. Dichas áreas naturales protegidas no podrán establecerse en zonas previamente declaradas como áreas naturales protegidas competencia de la federación, salvo que se trate de las señaladas en la fracción VI de este artículo.

Asimismo, corresponde a los municipios establecer las zonas de conservación ecológica municipales así como las demás categorías, conforme a lo previsto en la legislación local. En las áreas naturales protegidas no podrá autorizarse la fundación de nuevos centros de población ${ }^{49}$.

Por su parte el reglamento de la LGEEPA, en materia de Áreas Naturales Protegidas (ANP's), establece en el Artículo 37.- Las áreas que se incorporen al Sistema Nacional de Áreas Naturales Protegidas, de conformidad con lo establecido en el artículo 76 de la Ley, deberán presentar especial relevancia en algunas de las siguientes características:

I. Riqueza total de especies;

II. Presencia de endemismos;

III. Presencia de especies de distribución restringida;

IV. Presencia de especies en riesgo;

V. Diferencia de especies con respecto a otras áreas protegidas previamente incorporadas al Sistema Nacional de Áreas Naturales Protegidas;

VI. Diversidad de ecosistemas presentes;

VII. Presencia de ecosistemas relictuales;

VIII. Presencia de ecosistemas de distribución restringida;

\footnotetext{
${ }^{49}$ Ley General del Equilibrio Ecológico y Protección al Ambiente, Última reforma publicada DOF 04-06-2012.
} 
IX. Presencia de fenómenos naturales importantes o frágiles;

$X$. Integridad funcional de los ecosistemas;

XI. Importancia de los servicios ambientales generados, y

XII. Viabilidad social para su preservación.

De los cuales destaca la Integridad funcional de los ecosistemas y la importancia de los servicios ambientales generados; la aplicación de este Reglamento corresponde al Ejecutivo Federal, por conducto de la Secretaría de Medio Ambiente, Recursos Naturales y Pesca; así mismo establece que las ANP's deberán zonificarse de acuerdo a sus características biológicas, físicas y socioeconómicas, las cuales se tomaron en cuenta para establecer la zonificación primaria de "La Sabana".

En materia de Aguas Nacionales la autoridad y administración de sus bienes públicos inherentes corresponde al Ejecutivo Federal, quien la ejercerá directamente o a través de la Comisión Nacional del Agua. La Ley de Aguas Nacionales define a los humedales como las zonas de transición entre los sistemas acuáticos y terrestres que constituyen áreas de inundación temporal o permanente, sujetas o no a la influencia de mareas, como pantanos, ciénagas y marismas, cuyos límites los constituyen el tipo de vegetación hidrófila de presencia permanente o estacional; las áreas en donde el suelo es predominantemente hídrico; y las áreas lacustres o de suelos permanentemente húmedos por la descarga natural de acuíferos. Lo anterior resultó importante en los análisis geográficos para la delimitación del humedal "La Sabana". Por su parte se considera "Ribera o Zona Federal": Las fajas de diez metros de anchura contiguas al cauce de las corrientes o al vaso de los depósitos de propiedad nacional, medidas horizontalmente a partir del nivel de aguas máximas ordinarias. En nuestro caso una vez definido el humedal se estableció una franja de 50 metros para procurar mantener la selva de galería.

Con respecto de cuestiones urbanas, la Ley General de Asentamientos Humanos establece la congruencia entre la legislación urbana y ecológica con la política del desarrollo social e indica que la fundación de centros de población debe realizarse en tierras aptas para el aprovechamiento urbano, evaluando su impacto ambiental y 
preservando las áreas naturales protegidas, así como los valores, usos y costumbres de las comunidades rurales e indígenas.

Finalmente el Reglamento del Equilibrio Ecológico y la Protección al Ambiente para el Municipio de Othon P. Blanco establece en su artículo 47, con respecto de los Tipos y características de las áreas naturales protegidas las siguientes:

I. Zonas de Preservación Ecológica de los Centros de Población;

II. Parques Ecológicos Municipales; y

III. Aquellas áreas que los Municipios establezcan a fin de proteger su patrimonio natural. La administración de las áreas naturales protegidas a que hace referencia el presente artículo, quedarán sujetas a la administración del Municipio. En las áreas naturales protegidas no se autorizará la formación de nuevos centros de población.

Mientras que el Artículo 48 señala: Las Zonas de Preservación Ecológica de los Centros de Población, son las ubicadas dentro del territorio estatal, en zonas circunvecinas a los asentamientos humanos en las que existe uno o más ecosistemas en buen estado de conservación en los que se requiere la preservación y protección del suelo, cuencas hidrológicas, cuerpos de agua de competencia estatal y demás elementos naturales indispensables para el equilibrio ecológico y el bienestar general o que por su belleza natural, escénica, cultural, histórica, arqueológica o religiosa, sean representativos para la comunidad.

En dichas áreas podrá permitirse la realización de actividades relacionadas con la preservación, repoblación, propagación, restauración, aprovechamiento sustentable, refugio e investigación de las especies de flora y fauna silvestres, así como las relativas a la educación y difusión de la materia.

En relación a las ANP's, el Artículo 49, establece que los Parques Ecológicos Municipales son las áreas de uso público constituidas en los centros de población, para obtener y preservar el equilibrio ecológico en las áreas urbanas e industriales, entre las construcciones, equipamientos e instalaciones respectivas y los elementos de la naturaleza, de manera que se propicie y fomente un ambiente sano, el esparcimiento de la población y los valores artísticos e históricos y de belleza natural de la localidad. Por 
lo que de acuerdo a lo anterior, la definición que más describe las características de "La Sabana" son las señaladas en el artículo 48 como zona de preservación ecológica del centro de población de Chetumal.

A continuación se abordan los instrumentos de ordenamiento territorial ecológico y urbano, que tienen incidencia sobre el cuerpo de agua "La Sabana"; en ellos se establecen los criterios ecológicos, políticas, usos predominantes, compatibles, condicionados e incompatibles con las denominadas Unidades de Gestión Ambiental ${ }^{50}$ (UGA), y van a servir como lineamientos normativos para abordar el objeto de estudio. Destacan entre estos, el Programa de Ordenamiento Ecológico Territorial de la Región de Laguna de Bacalar (2005), y lo que correspondería a su actualización con la creación del Municipio de Bacalar y la correspondiente subdivisión del municipio de Othón P. Blanco: la propuesta del Programa de Ordenamiento Ecológico de Othón P. Blanco; esto con respecto de los Ordenamientos Territoriales, y con respecto de los Programas de Desarrollo Urbano: el Programa de Desarrollo Urbano de Chetumal, Calderitas y Xul-Ha, del 2018, donde se establecen, además de políticas, los usos y destinos de los humedales, en apoyo de la estructura urbana en general.

\subsubsection{Programa de Ordenamiento Ecológico Territorial de la Región de Laguna Bacalar; Quintana Roo, México}

Este Programa de Ordenamiento Ecológico se decretó en 2005. En él se establece un polígono específico para el humedal "La Sabana"51 denominado como Cn-19 (ver figura 49); es decir corredor natural, al que la definición presentada en el mismo documento, se refiere como un "Espacio de continuidad de ecosistemas que permite la conectividad entre áreas de conservación o protección mayores y aisladas por la modificación del

\footnotetext{
50 Unidades Ambientales, se definen como: Las áreas en las que están zonificados polígonos del área sujeta a Ordenamiento, definidas por rasgos geomorfológicos y ecológicos específicos, georeferenciados, en condiciones de homogeneidad, a la que se asignan determinados lineamientos y estrategias ecológicas (POET-BAC, 2005 y POELM-OPB, 20015).

51 Aunque éste se localizó dentro del polígono del asentamiento humano (Ah-3), correspondiente a la ciudad de Chetumal.
} 
entorno. Estos espacios permiten los flujos genéticos entre poblaciones de vida silvestre y de materia y energía entre ecosistemas." ${ }^{2}$

Figura 49. Unidades de Gestión Ambiental (UGA’s) asignadas por el Programa Ecológico Territorial de la Región de Lagua de Bacalar, 2005.

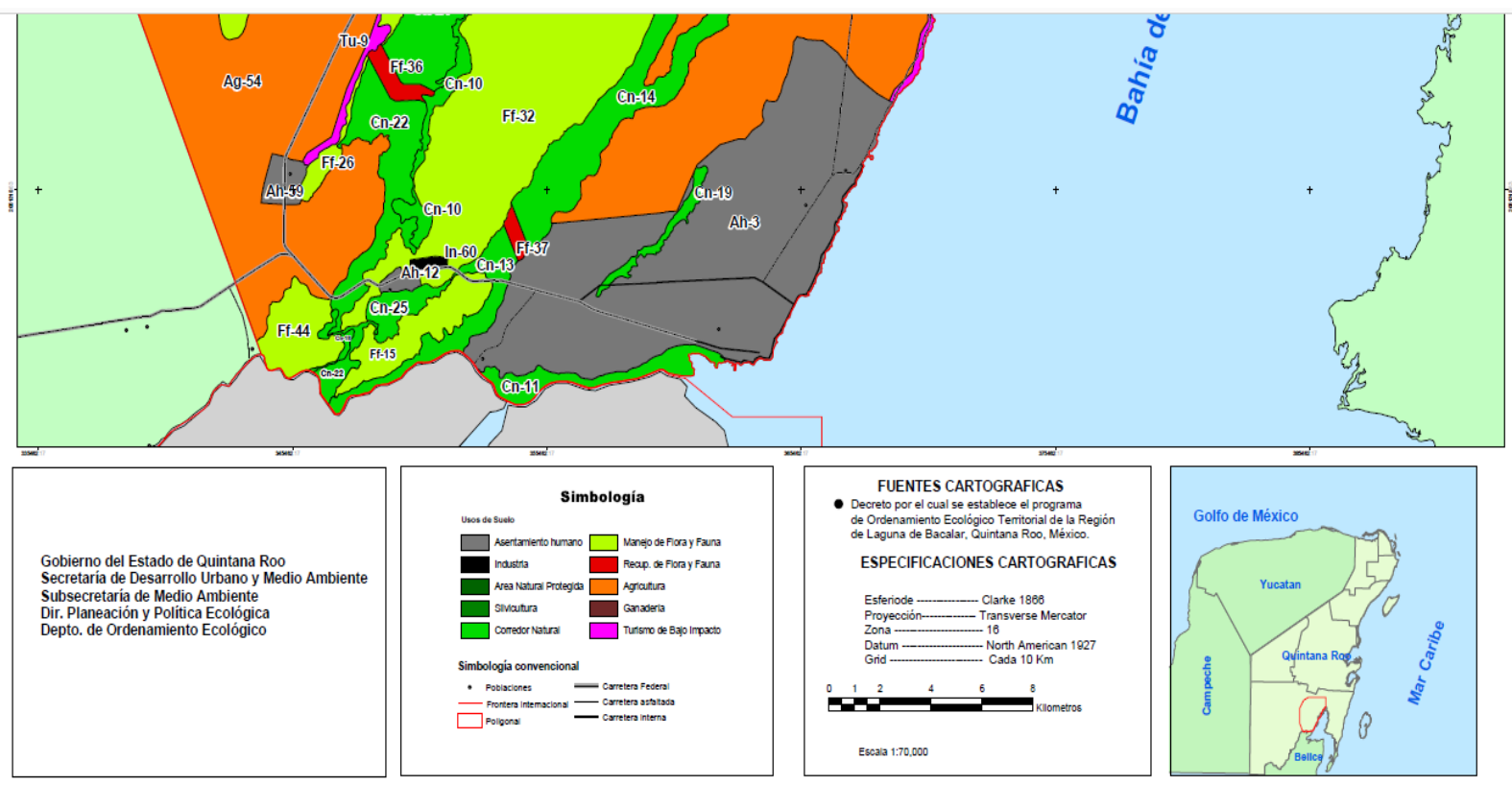

Fuente: Periódico Oficial del Estado de Quintana Roo. Tomo I, Número 5 Bis, Sexta Época. Chetumal, Quintana Roo. 15 de marzo de 2005. Decreto por el cual se establece el Programa de Ordenamiento Ecológico Territorial de la Región Laguna de Bacalar, Quintana Roo, México (a partir de ahora: POET-BAC, 2005)

Al polígono correspondiente a "La Sabana" se le asignan los usos y criterios siguientes (Tabla 1):

52 Periódico Oficial del Estado de Quintana Roo. Tomo I, Número 5 Bis, Sexta Época. Chetumal, Quintana Roo. 15 de marzo de 2005. Decreto por el cual se establece el Programa de Ordenamiento Ecológico Territorial de la Región Laguna de Bacalar, Quintana Roo, México (en adelante POETBAC, 2005). 


\begin{tabular}{|c|c|c|c|}
\hline \multicolumn{4}{|c|}{ al humedal "La Sabana". } \\
\hline Nombre: & Laguna & Identificador: & Cn-19 \\
\hline Política: & Protección & & \\
\hline \multicolumn{4}{|c|}{ Usos } \\
\hline & Predominante & \multicolumn{2}{|c|}{ Compatibles } \\
\hline & Corredor natural, & \multicolumn{2}{|c|}{ Manejo de flora y fauna, } \\
\hline & Oondicionados & \multicolumn{2}{|c|}{ Incompatibles } \\
\hline Turis & no Alternativo, Pesca, & \multicolumn{2}{|c|}{$\begin{array}{l}\text { Acuacultura, Agricultura, Agroforestería, ANP, } \\
\text { Apicultura, Aprovechamiento acuifero, } \\
\text { Asentamiento humano, Caza, Centro de población, } \\
\text { Equipamiento, Extracción pétrea, Forestal, } \\
\text { Ganadería, Industria, Infraestructura, Silvicultura, } \\
\text { Turismo hotelero intensivo }\end{array}$} \\
\hline
\end{tabular}

\begin{tabular}{|c|l|l|}
\hline \multicolumn{2}{|c|}{ Criterios } \\
\hline TA & Turismo alternativo & 02,03 \\
\hline Pe & Pesca & 01,02 \\
\hline Ma & Marinas & \\
\hline CG & Campos de Golf & \\
\hline Den & Densidades & \\
\hline BM & Bancos de Material & 04 \\
\hline Man & Manglares & $04,05,06$ \\
\hline Gan & Ganadería & \\
\hline Acu & Acuicultura & \\
\hline ZFMT & ZoFeMaT & \\
\hline Fa & Fauna & 01,06 \\
\hline MRS & Manejo de Residuos Sólidos & \\
\hline MRL & Manejo de Residuos Liquidos & 04 \\
\hline Agr & Agricultura & \\
\hline Flo & Flora & 12 \\
\hline Urb & Áreas Urbanas & \\
\hline Ind & Industria & \\
\hline CyC & Carreteras y Caminos & 01,02, \\
\hline IBS & Infraestructura Básica y de Servicios & 04 \\
\hline Cons & Construcción & 01,08 \\
\hline AA & Aprovechamiento del Acuífero & $03,04,05$ \\
\hline CoCo & Control de la Contaminación & 02,03 \\
\hline ANP & Áreas Naturales Protegidas & \\
\hline ZLC & Zona Litoral y Costera & $01,04,05$ \\
\hline AN & Actividades Náuticas & $01,02,03$ \\
\hline UMA & UMA & \\
\hline Ecoex & Ecosistemas excepcionales & \\
\hline
\end{tabular}

Fuente: Periódico Oficial del Estado de Quintana Roo. Tomo I, Número 5 Bis, Sexta Época. Chetumal, Quintana Roo. 15 de marzo de 2005. Decreto por el cual se establece el Programa de Ordenamiento Ecológico Territorial de la Región Laguna de Bacalar, Quintana Roo, México. 
De acuerdo a este instrumento, se establece como criterio general (Número 42) que: se prohíbe la desecación, dragado, y relleno de humedales y cuerpos de agua. Como criterios específicos se establecen los siguientes:

"para llevar a cabo actividades recreativas, científicas o de turismo alternativo, deberá elaborarse un programa de manejo; sólo se permite la práctica del campismo, rutas interpretativas, observación de flora y fauna, y paseos fotográficos; se permite la pesca deportiva, todas las actividades pesqueras estarán sujetas a lo establecido en la Ley Federal de Pesca y su reglamento vigente; no se permite la extracción de arenas y materiales calizos no consolidados; se permite el uso ecoturístico del manglar y los humedales para la contemplación de la naturaleza, paseos fotográficos y senderismo; en ningún caso se permitirá la disposición de aguas tratadas en el manglar; las obras de ingeniería que se realicen sobre humedales deberán contar con autorización en materia de impacto ambiental. La Manifestación de Impacto Ambiental deberá considerar las acciones para garantizar el flujo y reflujo de agua superficial y subterránea dentro y entre los ecosistemas, apegándose a la NOM-022-SEMARNAT-2003. Con respecto de la fauna, se prohíbe la extracción o captura de especies de flora y fauna silvestre, salvo autorización expresa de la SEMARNAT para pie de cría o investigación; sólo se permite la caza y comercio de fauna silvestre dentro de unidades de conservación, manejo y aprovechamiento sustentable de la vida silvestre (UMAS). Por su parte el manejo de residuos, prohíbe la descarga de drenaje sanitario y desechos sólidos sin tratamiento en los cuerpos de aguas y zonas inundables. A su vez, se prohíbe la introducción de especies exóticas. Con respecto de carreteras y caminos: los caminos que se realicen sobre zonas inundables deberán construirse de tal forma que garanticen los flujos hidrodinámicos así como la integridad de los corredores biológicos; en las vialidades que atraviesan zonas de conservación o protección, deben existir reductores de velocidad y señalamientos de protección de la fauna; mientras que se prohíbe la construcción de cualquier tipo de infraestructura básica y de servicios. En áreas sujetas a inundaciones, la infraestructura deberá construirse sobre pilotes, garantizando el flujo laminar del agua. Lo relativo al aprovechamiento del acuífero refiere que, para el aprovechamiento no extractivo de los cuerpos de agua, se deberá obtener autorización en materia de impacto ambiental; se prohíbe el aprovechamiento extractivo del acuífero sea superficial o subterráneo; y no se 
permite captación de agua subterránea para la transferencia de esta unidad a otra. Para el control de la contaminación, los canales de navegación estarán sujetos a un monitoreo que permita evaluar la calidad del agua y establecer medidas que eviten la contaminación hacia humedales, manglares y zonas adyacentes; sólo se permite el uso de bronceadores y bloqueadores solares de tipo biodegradable. No se permitirá la remoción de la vegetación acuática de lagunas, ríos y zona federal marítimo terrestre. En los cuerpos de agua interiores se prohíbe la instalación o construcción de plataformas flotantes no ligadas a tierra, fijas o móviles, para atracaderos, restaurantes, etcétera. Finalmente, con respecto de las actividades náuticas, se prohíbe el uso de motores fuera de borda tipo "pata larga" en las lagunas, con excepción de las actividades pesqueras permitidas, el tránsito y las actividades de vigilancia y emergencia; no se permite la práctica de actividades que requieran el uso de equipos motorizados acuáticos con excepción de las actividades de vigilancia y emergencia; para todas las actividades náuticas, los promotores deberán elaborar reglamentos de operación que minimicen los impactos ambientales. Dichos reglamentos serán sancionados por la SEDUMA" (POETBAC, 2005).

Este mismo documento establece en su anexo 4 (Ver Anexos), un listado florístico de especies nativas y cultivadas recomendadas y especies exóticas no recomendadas para uso ornamental, dentro del área de ordenamiento, el cual podría utilizarse como referencia para la selección de paleta vegetal del presente proyecto.

\subsubsection{Programa de Desarrollo Urbano de Chetumal, Calderitas, Subteniente López, Huay-Pix y Xul-Ha. Municipio de Othón P. Blanco, 2018.}

Este instrumento en particular, establece una política de protección a cuerpos de agua, estableciendo los siguientes lineamientos de ordenamiento ecológico:

a) Evitar que el desarrollo y la extensión urbana afecten a los cuerpos de agua y los humedales.

b) En este aspecto los cuerpos de agua estarán sujetos a políticas de protección y de conservación, fijándoles también una política de aprovechamiento condicionado dándole a su entorno la posibilidad de constituirse en parques (con vegetación natural) que amplíen la oferta urbana y a su vez se constituyan en zonas de amortiguamiento. En su 
caso, será posible la integración con elementos de equipamiento que guarden congruencia y compatibilidad con el objetivo de protección, aprovechamiento condicionado; por ejemplo áreas deportivas, parques y espacios culturales (PDU, 2018).

Esto se ve reflejado en la figura 50 , donde se establece la política de Protección a Cuerpos de Agua y humedales (PCA), a "La Sabana" y otras lagunas.

Figura 50. Estrategia Urbana en Función de Ordenamiento Ecológico.

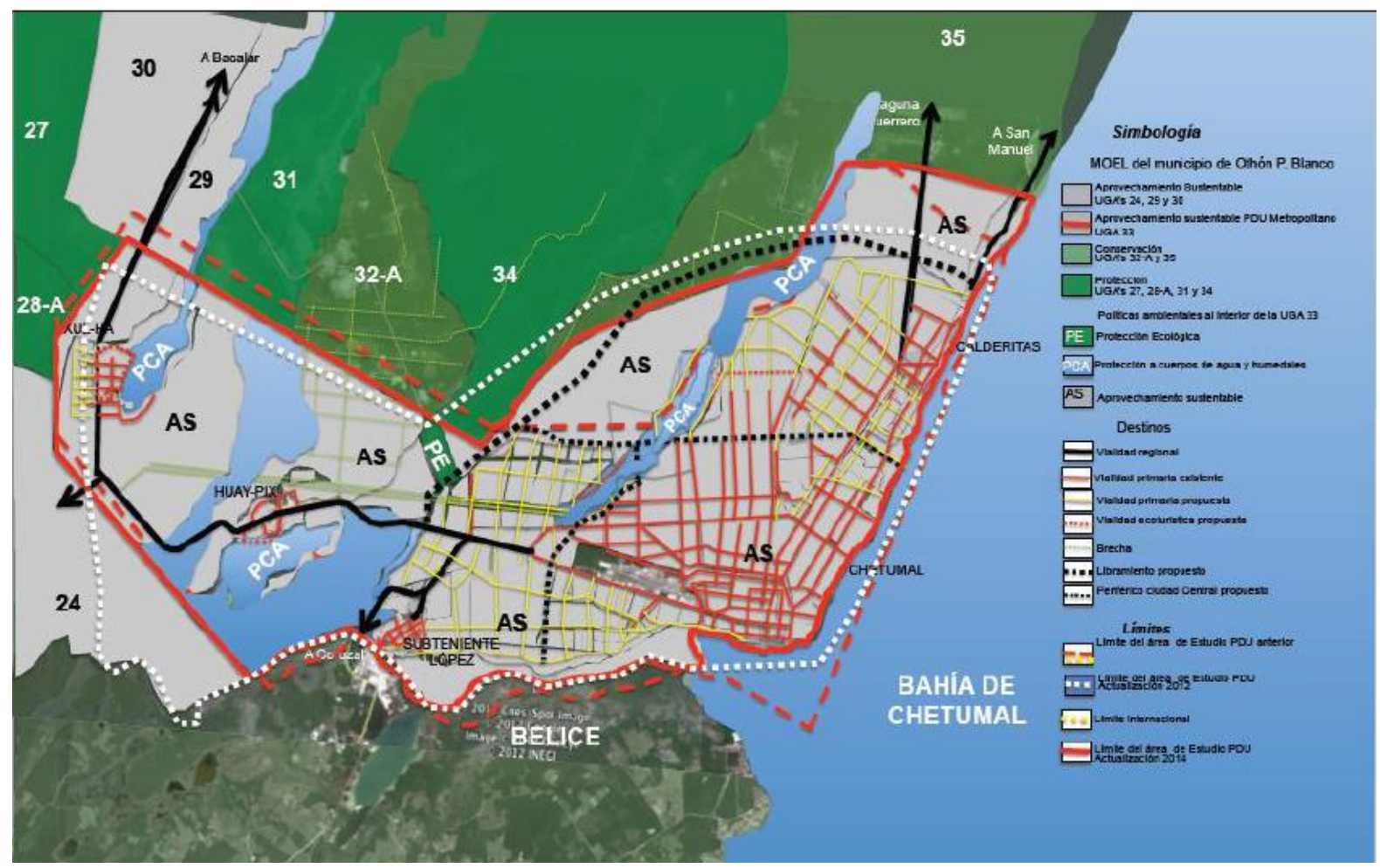

Fuente: Programa de Desarrollo Urbano de Chetumal, Calderitas, Subteniente López, Huay-Pix y Xul-Ha. Municipio de Othón P. Blanco, 2018.

El Programa de Desarrollo Urbano de Chetumal, Calderitas, Subteniente López, HuayPix y Xul-Ha. Municipio de Othón P. Blanco, 2018, establece que:

"las disposiciones específicas para estos cuerpos de agua, como Áreas de protección, refiriéndose a las áreas requeridas para la regulación y el control de los vasos hidráulicos tanto para su operación natural, como para los fines de 
explotación agropecuaria como de suministro a los asentamientos humanos. Las áreas de protección a los cuerpos de agua serán de 10.00 metros a partir de la cota máxima.

Estas áreas son del dominio de la Nación y de utilidad pública, estando bajo jurisdicción federal según lo estipulado por la Ley Federal de Aguas y la Ley General del Equilibrio Ecológico y la Protección al Ambiente. Las áreas de protección a los cuerpos de agua son coincidentes con la zona federal que existe en torno a estos elementos de la hidrología natural.

Su aportación a la cultura ambiental y sus valores ecológicos deben ser preservados y aprovechados con fines educativos y ecológicos. Se delimitarán áreas de protección y aprovechamiento sustentable de flora y fauna endémica en coordinación con las autoridades ambientales en la materia.

Las actividades permitidas son aquellas vinculadas con la protección de fauna y flora, la investigación científica, la educación y difusión cultural, la restauración de valores ambientales y el ecoturismo en la modalidad de: contemplación de flora y fauna, junto con las especificadas en la Matriz de Compatibilidad de Usos y Destinos.

Como normas particulares se tienen que la instalación y construcción de infraestructura recreativa será posterior al área de protección de cuerpos de agua (es decir, después de los 10.00 metros) y serán aquellas que brinden servicios (vestidores, restaurantes con servicios sanitarios existentes), infraestructura recreativa y la que brinde apoyo a la población: casetas de emergencia, información turística y seguridad pública.

En cuanto a la zonificación secundaria y referidos a la estructura urbana territorial y dosificación del equipamiento urbano, relativos a Parques urbanos, áreas verdes y espacios públicos, se establecieron normas específicas para "La Sabana", denominada como "Parque urbano La Sabana": 
El parque urbano La Sabana es una de las propuestas centrales de este Programa de Desarrollo Urbano, el que con una superficie planteada de 601.74 hectáreas se convertiría en la principal área verde de toda la ciudad de Chetumal.

Tal como se planteó en la conceptualización general urbanística, el parque urbano La Sabana se establece para alcanzar un aprovechamiento integral del cuerpo lagunar homónimo y de la franja de superficie de su entorno, con esto se buscará como primera medida el mejoramiento del indicador de metros cuadrados de área verde por habitante para los chetumaleños.

Como segundo aspecto, de vital importancia, es salvaguardar los servicios que aporta este entorno a la ciudad; entre los que se encuentran el control hidrológico y pluvial, área verde y espacios recreativos [como ya se indicó], así como su función como refugio para la fauna y flora nativa que se ha aclimatado a una vida urbana; lo que en conjunto constituirá un espacio que funcione como un gran parque urbano [figura 51].

En el Parque Urbano La Sabana, se permiten la ubicación de un conjunto de equipamientos culturales, recreativos, deportivos en su interior, de acuerdo con la cartera de proyectos estratégicos. El propósito de lo anterior es generar un concepto de parque urbano acorde a las tendencias existentes en este ámbito en cuanto a conformar espacios y actividades integrales; por ejemplo el caso del conjunto de museos, es similar a otras ciudades mexicanas y del extranjero (como referencia se puede mencionar al Bosque de Chapultepec en la Cd. de México, el Parque Tomás Garrido en Villahermosa, y en Tuxtla Gutiérrez, entre otros).

Los proyectos asociados al Parque urbano La Sabana son:

- 2 puentes viales como símbolo-escultura urbana.

- Centro de Interpretación y Educación Ambiental de La Sabana.

- Centro de Investigaciones y Difusión de la Cultura Indígena Maya.

- Granja educativa sobre energía solar y eólica. 
- Jardín botánico de Quintana Roo.

- Museo de Arqueología del sur de Quintana Roo.

- Museo de Arte de Quintana Roo.

- Museo de Historia de Quintana Roo.

- Museo del Agua.

- Nueva ciudad administrativa (posiblemente).

- Unidad deportiva norponiente.

- Vivero forestal y de ornato.

La ubicación concreta de cada uno de los elementos antes enlistados al interior de las 601.74 hectáreas del parque urbano La Sabana, como la superficie específica de terreno que se dispondrá para cada uno se definirá en el plan o programa de manejo y en los proyectos ejecutivos que se elaboren" (PDU, 2018). 
Figura 51. Plano de Zonificación secundaria -Usos de suelo; localización del parque urbano "La Sabana".

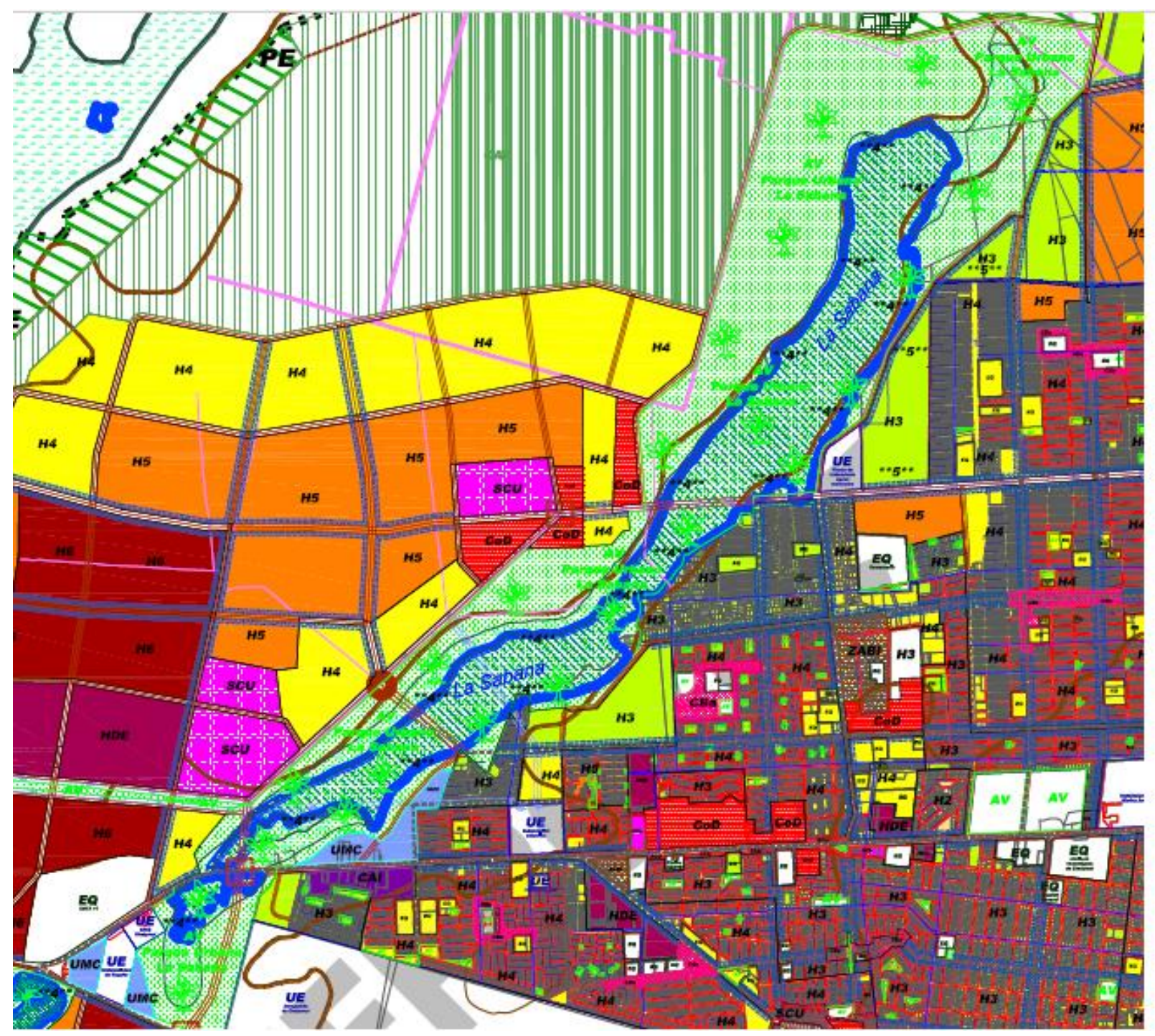

Fuente: Programa de Desarrollo Urbano de Chetumal, Calderitas, Subteniente López, Huay-Pix y Xul-Ha. Municipio de Othón P. Blanco, 2018. 2018.

\section{CONCLUSIÓN DEL CAPÍTULO}

La caracterización del humedal "La Sabana" y su zona de estudio permite tener en consideración los siguientes aspectos:

- A escala regional comprender el funcionamiento de los flujos superficiales del humedal hasta desembocar en la Bahía de Chetumal 
- Relacionar o sobreponer capas cartográficas de tipos de suelo, vegetación, cuerpos de agua, y topografía del INEGI para reconocer y establecer los límites del polígono de "La Sabana" en el contexto de la escala urbana, mismo que será el área de intervención del "Plan Maestro urbano paisajístico".

- La presión urbana constante y permanente sobre el humedal, dado por asentamientos humanos irregulares, rellenos sobre el humedal, y contaminación por falta de servicios municipales a la vivienda, mermando la calidad de vida y con grados altos de marginación.

- Una baja valoración social sobre el paisaje del humedal.

Derivado de estos aspectos, surge la disyuntiva sobre el manejo de "La Sabana":

- La visión ecológica de protección sobre el cuerpo de agua y la posibilidad de convertirse en un Área Natural Protegida.

- La visión urbana de aprovechamiento sobre el entorno del humedal para incluir actividades urbanas y equipamientos urbanos.

Ante estas dos posibilidades surge la siguiente pregunta ¿Cuál sería la manera más adecuada para el manejo y/o gestión del Humedal, que permita seguir cumpliendo sus funciones ecológicas y se integre a la dinámica de una ciudad en constante crecimiento?

Para atender esto, se realizó un cuestionario mismo que buscaba resolver, a través de la percepción ciudadana, cuál sería el mejor uso para el humedal, dicho estudio se basó en cuestionarios a personas clave de la ciudad: servidores públicos municipales en el área de desarrollo urbano, medio ambiente y ecología, catedráticos del Instituto Tecnológico de Chetumal y la Universidad de Quintana Roo, Secretarías y Dependencias estatales en materia de ordenamiento territorial y Protección al ambiente, Desarrolladores inmobiliarios y público en general; las preguntas que conformaron el cuestionario fueron:

1. Describa brevemente el humedal "La Sabana"

2. ¿Cuál es el futuro deseable para el humedal "La Sabana”? 
3. Describa cuál es la función del humedal "La Sabana", desde la visión o planteamiento de su organismo o institución (o personal).

4. Enliste los usos más adecuados para "La Sabana" de acuerdo a lo anterior (al menos 10)

5. Qué usos son incompatibles con el humedal (al menos 5)

Los resultados se presentaron en el 3er Congreso Internacional de Parques Urbanos, convocado por la Asociación Nacional de Parques y Recreación en 2020, con la ponencia titulada "Perspectivas para el humedal La Sabana, gran parque metropolitano o Área Natural Protegida"; a continuación, se comparten algunas respuestas representativas que son coincidentes o divergentes entre sí:

1. Describa brevemente el humedal "La Sabana"

- Un humedal es un ecosistema inundable, es un filtro natural que por sus características ha sido imitado en humedales artificiales para tratamiento de aguas residuales. El Humedal conocido como La Sabana, ha visto interrumpido su flujo natural de aguas por el mal llamado puente que en realidad en un relleno. La Sabana se ha convertido en escenario de asentamientos irregulares, no necesariamente de relegados sociales sino abarca un amplio panorama de rangos sociales que se han visto atraídos a las cercanías, sin considerar o importar las condiciones de habitabilidad encontradas en este lugar.

- Cuerpo de agua que debería ser considerada como un Área Natural Protegida (ANP), puesto que cuenta con todas las características para serlo, sin embargo, el impacto ocasionado por los asentamientos humanos en gran parte del humedal han deteriorado muchas de sus funciones, así como la calidad del agua. Es un ecosistema que se encuentra en peligro y requiere de estudios para ser incluido como una ANP y pueda ser tomado en cuenta para su posterior conservación y protección. 
2. ¿Cuál es el futuro deseable para el humedal "La Sabana"?

- Desde mi punto de vista, un futuro deseable sería sanear el lugar, es decir, eliminar el relleno y construir un puente, diseñar medidas sanitarias para los asentamientos humanos, implementar reglamentos para evitar rellenos que se realizan de manera clandestina en el humedal, entre otros.

- Su conservación inmediata en un estado lo menos afectado posible, y así, pueda mantenerse como zona de recarga acuífera de la ciudad, hábitat de las diferentes especies de fauna y muchos otros beneficios que aporta este humedal.

- Desde mi punto de vista, creo lo mejor fuera un parque urbano que tenga una visión de conservación de la flora y fauna, donde se pudiera realizar diversas actividades minimizando los impactos ambientales y conservando los elementos del ecosistema.

3. Describa cuál es la función del humedal "La Sabana", desde la visión o planteamiento de su organismo o institución (o personal).

- La función es biosocial, tiene una función como ecosistema pero también puede ser combinada con funciones sociales, si es posible la existencia de asentamientos humanos que pudieran beneficiarse de este ecosistema, pero tienen que ser planeados y reglamentados para que sea sustentable.

- La función principal del humedal "La Sabana" además de ser un importante hábitat para muchas especies de flora y fauna, es un ecosistema que aporta innumerables beneficios o servicios ecosistémicos y antropogénicos, desde suministrar agua dulce, alimento, hasta actuar como filtradores naturales de contaminantes, entre muchas otras funciones.

- Que dicho parque urbano "La Sabana" se establezca para alcanzar un aprovechamiento integral del cuerpo lagunar homónimo y de la franja de superficie de su entorno, con esto se buscará como primera medida el mejoramiento del indicador de metros cuadrados de área verde por habitante para los chetumaleños. Como segundo aspecto, de vital importancia, es salvaguardar los servicios que aporta este entorno a la ciudad; entre los que se encuentran el control hidrológico 
y pluvial, área verde y espacios recreativos (como ya se indicó), así como su función como refugio para la fauna y flora nativa que se ha aclimatado a una vida urbana; lo que en conjunto constituirá un espacio que funciones como un gran parque urbano.

4. Enliste los usos más adecuados para "La Sabana" de acuerdo a lo anterior (al menos 10).

- Agricultura sustentable

- Pesca sustentable

- Turismo sustentable

- Hábitat y refugio para fauna acuática, terrestre, aves endémicas y migratorias

- Restaurador de cuencas hidrológicas (recarga de los mantos freáticos)

- Regulación de la temperatura ambiental

- Fuente de agua para la flora y fauna

- Evitar la erosión del suelo

- Protección contra inundaciones

- Ayuda a conservar la biodiversidad

- Aporta alimento tanto para los animales como para los humanos

- Tiene gran capacidad para fijar dióxido de carbono

- Mitigador del cambio climático

- centro de monitoreo.

- centro de investigación

- Pista de Atletismo 
- senderismo

- camping

- vivero

- paseo en lancha (sin motor)

- punto de captación de agua pluvial.

- observatorio de la fauna.

- gimnasio al aire libre

- cine a cielo abierto

- centro de capacitacion de flora curativa.

- pesca deportiva

5. Qué usos son incompatibles con el humedal (al menos 5)

- Habitacional

- comercial

- Extracción de madera

- Extracción de agua

- Cambio de uso de suelo

- Turístico

- Agrícola

- Pecuario

- Industrial

- asentamientos humanos.

- cuerpo de descarga de aguas

- banco de material

- relleno de humedal 
- deforestación

- Club nocturno

- clínicas-hospital

- Embajadas

- Cementerios

- Industria textil

- Supermercados

- Farmacias

- Carnicerías

- Guarderías

- Vivienda Multifamiliar vertical y horizontal.

Del universo de respuestas mostradas anteriormente, se puede observar dos grandes visiones para el humedal, por un lado, una visión proteccionista, compatible con servicios ambientales, y por el otro lado, una visión de aprovechamiento compatible con las actividades y funciones urbanas; que por la afinidad de funciones se podría configurar dentro de un Área Natural Protegida o bien como gran parque urbano (ver cuadro siguiente).

Tabla 4. Cuadro resumen por afinidad de funciones para el Humedal "La Sabana".

\begin{tabular}{|l|l|}
\hline \multicolumn{1}{|c|}{ ANP } & \multicolumn{1}{c|}{ PARQUE URBANO } \\
\hline$\cdot$ Protección & $\cdot$ Servicios culturales \\
$\cdot$ Servicios ambientales & - Ecoturismo \\
$\cdot$ Recuperación & $\cdot$ Equipamiento urbano: deportivo, \\
$\cdot$ Servicios culturales & \multicolumn{1}{c|}{ cultural, educativo } \\
\hline
\end{tabular}

Los resultados estuvieron divididos entre estas dos grandes perspectivas: la urbana de aprovechamiento y la ecológica proteccionista; que más que incompatibles deberían ser complementarias, dejando en claro que "La Sabana" tendría que fungir con ambas aspiraciones, para dotar a la ciudad de lo que podría llegar a ser el gran Parque 
Metropolitano de Chetumal con función social, urbana y ambiental, que caracterice a un pueblo por su identidad y la calidad de su paisaje.

\section{CAPÍTULO 4. DIAGNÓSTICO INTEGRADO}

El presente capítulo describe y analiza la situación actual en torno al humedal "La Sabana" en términos urbanos, paisajísticos, ambientales y sociales, así como las amenazas y riesgos naturales asociadas al clima y su variabilidad global. Con ello se identifican las limitantes y potencialidades para el desarrollo y aprovechamiento integral de "La Sabana", y se define la imagen objetivo de la que se desprenden las directrices de diseño urbano paisajístico, articuladas y sistematizadas en el Plan Maestro, cuya confección permitirá establecer medidas racionales para recuperar, y revalorar "La Sabana", en beneficio de los habitantes de la ciudad de Chetumal.

\subsection{Situación actual}

\subsubsection{Aspectos urbanos}

El entorno urbano colindante con el humedal se puede definir en términos de estructura urbana, calidad o condición actual de las infraestructuras y servicios básicos a la vivienda, y los equipamientos urbanos.

Con respecto de la estructura urbana, este presenta una geometría ortogonal sobre la que se extienden las vialidades hasta concluir con el humedal, siendo en algunos casos verdaderas ventanas al paisaje, pero por otro lado una geometría que no se adapta a las formas naturales propias del humedal, por lo que no existe continuidad física, ni se establecen zonas de amortiguamiento, imposibilitando la conectividad vial.

Sobre las características actuales de las redes viales, podemos mencionar que algunas calles son de terracería, por lo que se requiere mejorar los pavimentos y el servicio de iluminación en vialidades; así mismo existe carencia de mobiliario urbano como botes de basura, paraderos para el transporte público y sitios de descanso. 
Con respecto de los servicios municipales a la vivienda, la principal carencia es el drenaje, condición que afecta directamente al humedal.

Por su parte los equipamientos urbanos son prácticamente inexistentes, a excepción de una escuela en las cercanías, y hay un déficit de áreas verdes urbanas funcionales, es decir que puedan usarse para el descanso y el recreo, a excepción del mismo humedal que cumple con estas funciones.

El principal problema se encuentra en la falta de relación entre la ciudad y el humedal, una falta de diseño e integración urbana debido a los asentamientos irregulares y al trazo de caminos sobre "La Sabana" mal ejecutados o con falta de mantenimiento, además de los rellenos que ha habido para la construcción de viviendas; todos los aspectos anteriores están vinculados a la falta de vigilancia y aplicación de las leyes y normas que regulan el uso del humedal y el desarrollo urbano ordenado, además de una baja conciencia ambiental o valoración del humedal por parte de la sociedad.

La falta de infraestructura como drenaje sanitario a las viviendas, es uno de los motivos por el cual se ve contaminado el humedal, además de que funge como cuerpo receptor de la planta de tratamiento "Centenario", de la cual existen diversas manifestaciones periodísticas y científicas que ponen en duda la calidad de las aguas tratadas y vertidas al humedal. Al respecto Emmanuel Quevedo, manifiesta en su tesis para obtener el grado de Ingeniero Ambiental por la Universidad de Quintana Roo (2014), que "el agua residual que entra a la Planta no es tratada en su totalidad, en ocasiones el $100 \%$ del caudal es desviado y descargado en "La Sabana" sin tratamiento alguno", mientras que el agua tratada no cumple con los requerimientos señalados en las Normas Oficiales Mexicanas para su descarga en cuerpos de agua.

Por su parte, existe carencias en infraestructura que demerita la imagen urbana de la zona, como falta de pavimento en calles, banquetas, iluminación en vialidades y mobiliario urbano. A todo ello se siguen sumando asentamientos humanos irregulares e incrementado la problemática de carencia de servicios. 


\subsubsection{Aspectos Ambientales}

Ya se han reconocido los servicios ambientales que aportan los humedales en general. En el caso específico de "La Sabana" podemos enumerar el drenaje de las lluvias, evitando inundaciones a la ciudad, captura de carbono en sus aguas y en la vegetación, así como hábitat de aves y peces. Por su parte los servicios culturales son importantes en la zona, pues la gente se reúne en sus inmediaciones para la pesca recreativa, de subsistencia y comercial, el canotaje, y la convivencia familiar y social.

Queda claro que los principales impactos que se ejercen sobre "La Sabana" son producidos por la presencia del hombre, la cercanía de los asentamientos humanos irregulares que carecen de servicios y con ello la contaminación por descargas residuales.

A ello se suman los caminos que atraviesan el humedal, con falta de diseño y construcción inadecuados que alteran el funcionamiento natural de "La Sabana", desde el cuerpo de agua permanente que colinda con el área urbana de Chetumal, como los caminos que comunican los asentamientos rurales hacia el centro-norte del humedal (figura 52).

Otro factor de degradación son los cambios de uso de suelo generado por rellenos de particulares para ganarle terreno al cuerpo de agua, y los desmontes sobre la cobertura original para utilizarlos como terrenos de cultivo y ganadería, o bien destinados a bancos de materiales para la construcción. A las prácticas de desmonte para abrir nuevos terrenos para los usos agropecuarios, se suman los riesgos que implica el uso intensivo de fertilizantes o pesticidas, que al incorporarse al agua que se infiltra, finalmente estos deshechos tóxico son descargados al cuerpo de agua y posteriormente a la Bahía de Chetumal.

Finalmente el desconocimiento general sobre la importancia del humedal "La Sabana" y una falta de cultura y conciencia ambiental, es el reflejo del deterioro y los impactos generados sobre este elemento natural (ver figuras 52 a 54 y tabla 5). 
Figura 52. Impactos ambientales sobre el humedal "La Sabana"

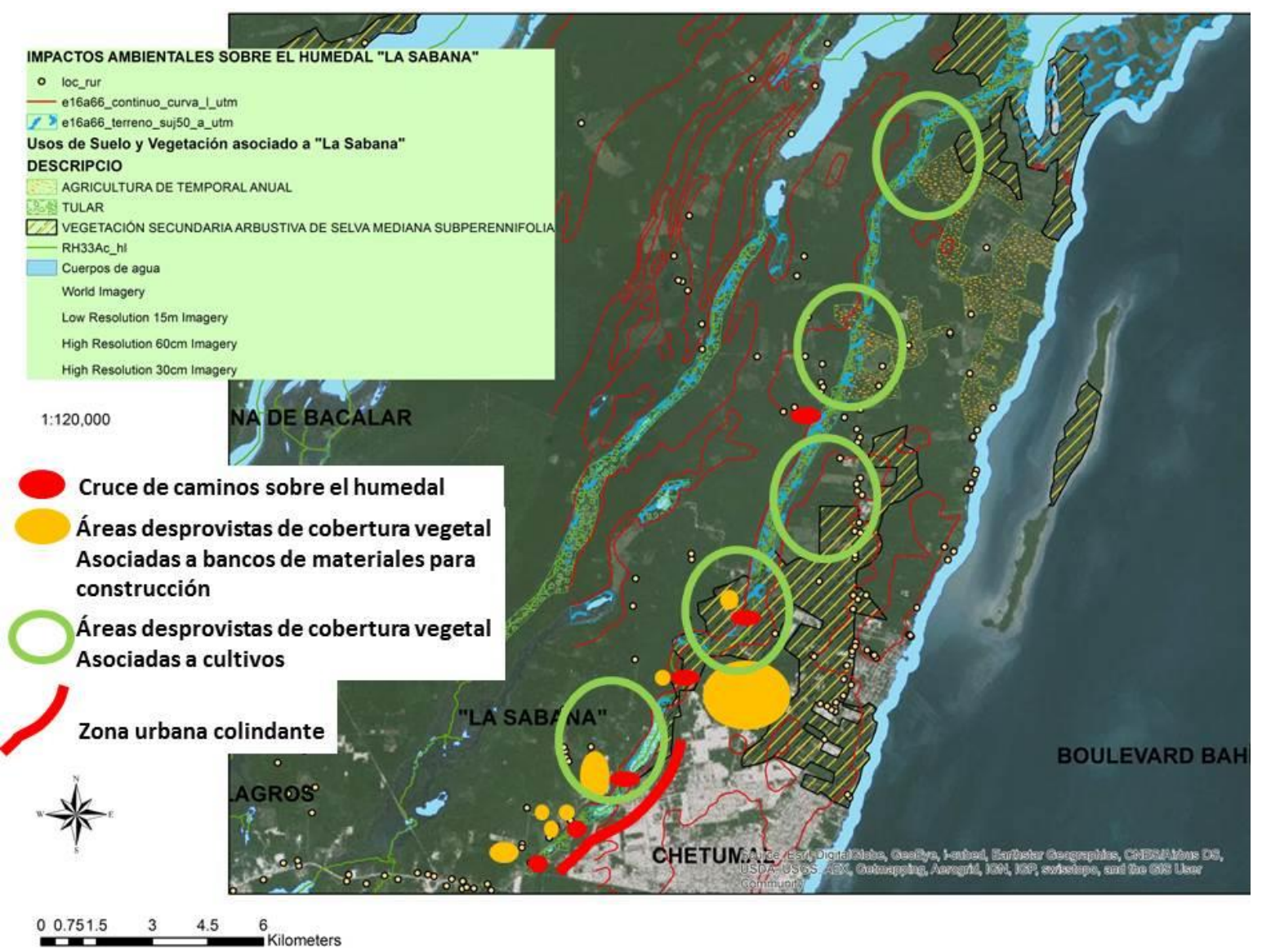

Fuente: Elaboración propia, con cartografía de INEGI, en programa Arc Gis 10.2

Otro factor que se ve reflejado en el deterioro es la falta de vigilancia sobre el humedal por parte de las autoridades Medioambientales, pues, aunque es competencia de los tres órdenes de gobierno, esto en ocasiones se traduce en un desentendimiento total por parte de las autoridades.

\subsubsection{Aspectos Sociales: relación con el humedal, percepción social y vulnerabilidad}

La relación entre la población de las inmediaciones con "La Sabana" son ambivalentes, mientras que existen grupos que se relacionan fuertemente con el humedal a través de las actividades de recreo y comerciales que ofrece la pesca, otros prefieren dar la espalda al humedal negando su relación. Esto se ve reflejado por un lado en la concentración de 
la población en los puntos de acceso al humedal que permiten los caminos que cruzan el camino, y por otro las encuestas de percepción presentadas en el capítulo anterior.

Los problemas referidos a la vulnerabilidad social, están asociados a las carencias que tiene la población con relación al acceso a bienes y servicios a la vivienda, que se mencionaron en el apartado de zonas de marginación urbana, mismas que son propias a las condiciones de irregularidad de los asentamientos. Sin embargo, el concepto de vulnerabilidad social está referido a la capacidad que tiene un determinado conglomerado humano para hacer frente a condiciones adversas y reponerse a ellas, como fenómenos naturales: Iluvias atípicas, inundaciones, tormentas o el cambio climático. En este sentido la zona de estudio tiene una alta vulnerabilidad social ante la posible presencia de estos fenómenos naturales.

\subsubsection{Aspectos Paisajísticos}

Los aspectos urbanos, ambientales y sociales, se ven reflejados en el paisaje, de tal manera que las áreas del humedal que colindan con la ciudad, como los asentamientos, las viviendas, las infraestructuras, forman parte de este escenario paisajístico. Como se mencionó en el apartado del marco teórico, en "La Sabana" conviven paisajes culturales de carácter excepcional, paisajes urbanos cotidianos y degradados. Además, su importancia ambiental y cultural se reviste de los intereses sociales públicos y privados que se ven reflejados en los planteamientos de desarrollo de la zona para el futuro, vistos en el proyecto del Programa de Desarrollo Urbano.

En este sentido las problemáticas paisajísticas están en función de reconocer las cualidades de todo el escenario paisajístico: el urbano, el ambiental y el social (ver cuadro $4)$.

\subsubsection{Amenazas, Riesgos Naturales y Cambio Climático}

Las amenazas naturales en todo el estado de Quintana Roo están asociadas a lluvias atípicas, mareas de tormenta y huracanes. El Riesgo se da cuando las condiciones de vulnerabilidad social y la amenaza natural o antropogénica se hace presente. 
Ante las amenazas naturales poco se puede hacer para evitarlas, pero si es posible mejorar las infraestructuras, las viviendas y la planificación urbana y paisajística para enfrentarlas de la mejor manera posible. En este caso se estarían generando también las condiciones de adaptación ante el cambio climático

Por su parte con el cambio climático puede esperarse que estas amenazas y riesgos se incrementen y tengan un efecto negativo tanto sobre la población, como sobre el propio sistema natural, como sequías o lluvias intensas.

Esto se reflejaría en los diferentes estudios y mapas que se han generado de áreas afectadas por inundaciones ante lluvias atípicas, mareas de tormenta, y otras afectaciones que hay sobre la zona, como el Programa Estatal de Acción ante el Cambio Climático de Quintana Roo, los Atlas de Riesgos, y los Programas de Desarrollo Urbano locales.

\subsection{Limitantes y potencialidades}

Derivado de los aspectos anteriores se integró un cuadro resumen identificando las principales potencialidades y limitantes que hay sobre el humedal "La Sabana" en cuanto a lo social, urbano, paisajístico y ambiental.

Tabla 5. Cuadro síntesis de Potencialidades y Limitantes de "La Sabana"

\begin{tabular}{|c|c|}
\hline POTENCIALIDADES & LIMITANTES \\
\hline URBANAS & URBANAS \\
\hline $\begin{array}{l}\text { - Vialidades que generan ventanas al } \\
\text { paisaje } \\
\text { - Infraestructura en desarrollo } \\
\text { - Interés de Proyectos de Desarrollo } \\
\text { en la zona vertidos en la propuesta } \\
\text { del PDU }\end{array}$ & $\begin{array}{l}\text { - } \text { Asentamientos irregulares } \\
\text { - } \quad \text { la formactura urbana incoherente con } \\
\text { - } \quad \text { Presencia de caminos que } \\
\text { atraviesan el humedal y afectan su } \\
\text { funcionamiento natural } \\
\text { - } \text { Ausencia de drenaje municipal } \\
\text { - Vertido de aguas provenientes de la } \\
\text { planta de tratamiento } \\
\text { - Rellenos sobre el humedal } \\
\text { - Asentamientos humanos en zonas } \\
\text { inundables del humedal }\end{array}$ \\
\hline SOCIALES & SOCIALES \\
\hline $\begin{array}{l}\text { Intereses de grupos por el } \\
\text { desarrollo de la zona }\end{array}$ & - Resistencia al cambio \\
\hline
\end{tabular}




\begin{tabular}{|c|c|}
\hline $\begin{array}{l}\text { - Identificación de grupos sociales } \\
\text { con el humedal por actividades de } \\
\text { aprovechamiento } \\
\text { - Reconocimiento de la población del } \\
\text { humedal como "La Sabana" } \\
\text { - Reconocimiento del humedal como } \\
\text { proveedor de beneficios } \\
\text { ambientales y culturales }\end{array}$ & $\begin{array}{l}\text { - Incertidumbre con la tenencia de la } \\
\text { tierra } \\
\text { - Presencia de grupos de interés } \\
\text { sobre la tierra que fomentan los } \\
\text { asentamientos irregulares } \\
\text { - Poca participación ciudadana por la } \\
\text { protección de los paisajes y el } \\
\text { medio ambiente } \\
\text { - Desconocimiento general de la } \\
\text { ciudadanía de la importancia del } \\
\text { humedal } \\
\text { - Poca divulgación sobre el humedal } \\
\text { - Asentamientos humanos en zonas } \\
\text { inundables del humedal } \\
\text { - Asentamientos humanos con Altos } \\
\text { grados de marginación colindantes } \\
\text { con “La Sabana” }\end{array}$ \\
\hline AMBIENTALES & AMBIENTALES \\
\hline $\begin{array}{l}\text { - } \begin{array}{l}\text { Capacidad de recuperación del } \\
\text { humedal }\end{array} \\
\text { - } \quad \text { Normas de Protección sobre } \\
\text { cuerpos de agua } \\
\text { - El humedal como regulador de } \\
\text { inundaciones } \\
\text { - Servicios ambientales aportados } \\
\text { por el humedal } \\
\text { - Relación funcional con la Bahía de } \\
\text { Chetumal "Reserva Estatal } \\
\text { Santuario del Manatí" } \\
\text { - Potencial de integrar el área } \\
\text { funcional del humedal como ANP } \\
\text { - Presencia de áreas verdes urbanas } \\
\text { en el interior de Chetumal para } \\
\text { constituir corredores verdes } \\
\text { conectados con las áreas naturales } \\
\text { Presencia de vegetación secundaria } \\
\text { arbustiva de selva mediana } \\
\text { superennifolia }\end{array}$ & 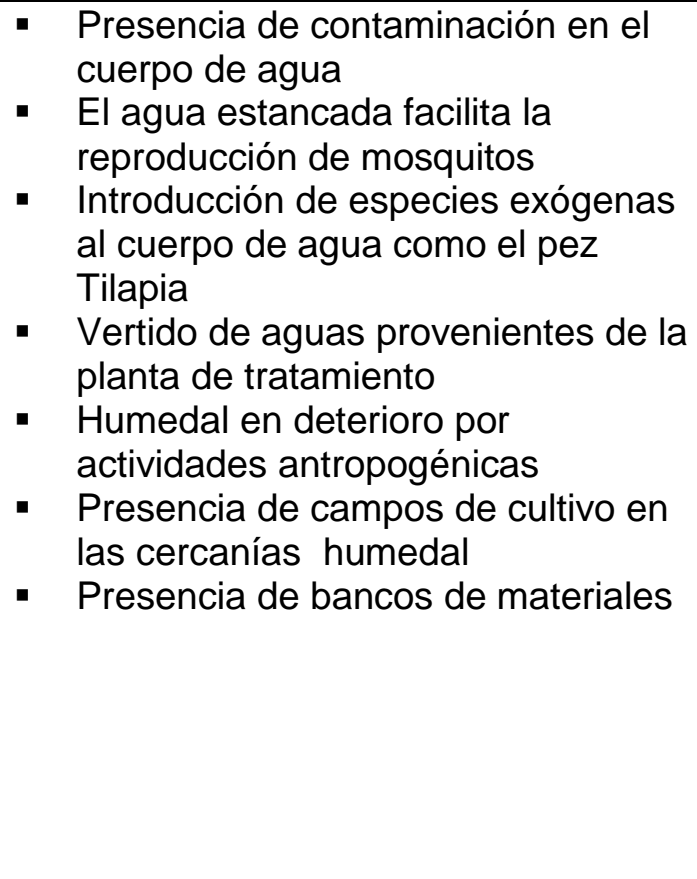 \\
\hline PAISAJISTICAS & $\begin{array}{l}\text { PAISAJISTICAS } \\
\end{array}$ \\
\hline $\begin{array}{l}\text { - Reconocimiento del humedal como } \\
\text { punto de interés paisajístico para el } \\
\text { desarrollo inmobiliario } \\
\text { - El humedal como elemento de } \\
\text { integración urbana y paisaística } \\
\text { - El humedal como elemento para } \\
\text { actividades ecoturísticas y } \\
\text { recreativas }\end{array}$ & $\begin{array}{l}\text { - } \quad \text { Paisajes deteriorados } \\
\text { - } \quad \text { Falta de normas de protección al } \\
\text { - } \text { paisaje } \\
\text { Baja valoración social }\end{array}$ \\
\hline
\end{tabular}




\begin{tabular}{|c|c|}
\hline $\begin{array}{l}\text { - } \begin{array}{l}\text { Reconocimiento de la población del } \\
\text { humedal como "La Sabana" }\end{array} \\
\end{array}$ & \\
\hline POLÍTICAS Y NORMATIVAS & POLITIICAS Y NORMATIVAS \\
\hline $\begin{array}{l}\text { - Instituciones de gobierno que } \\
\text { apoyan acciones destinadas a la } \\
\text { regularización de la tenencia de la } \\
\text { tierra } \\
\text { - Existencia de Normas para la } \\
\text { protección de cuerpos de agua } \\
\text { El PDU lo contempla como zona de } \\
\text { Desarrollo, con uso de parque } \\
\text { urbano }\end{array}$ & 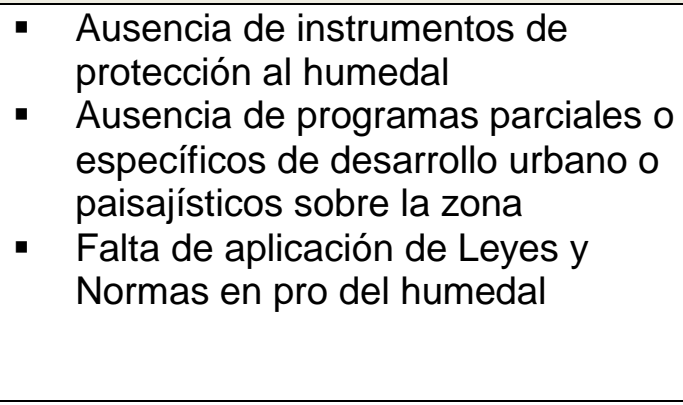 \\
\hline
\end{tabular}

Las siguientes figuras muestran las principales potencialidades y limitantes identificadas con respecto del humedal "La Sabana" y su contexto urbano, paisajístico y ambiental, razón por la cual se presentan a diferentes escalas para facilitar su análisis y lectura.

En la figura 53, se muestra la relación del humedal con el área urbana de la Ciudad de Chetumal y el funcionamiento general del humedal, señalado por el flujo superficial que desemboca en la Bahía de Chetumal. En la figura 54, se reconocen las potencialidades y limitaciones en la relación urbano paisajística; mientras que en la figura 55 , se identifican las problemáticas y potencialidades, en una relación directa humedal-contexto urbano. 
Figura 53. Mapa de Potencialidades y Limitantes del humedal "La Sabana". Escala de la Ecología del Paisaje o de funcionamiento natural del humedal.

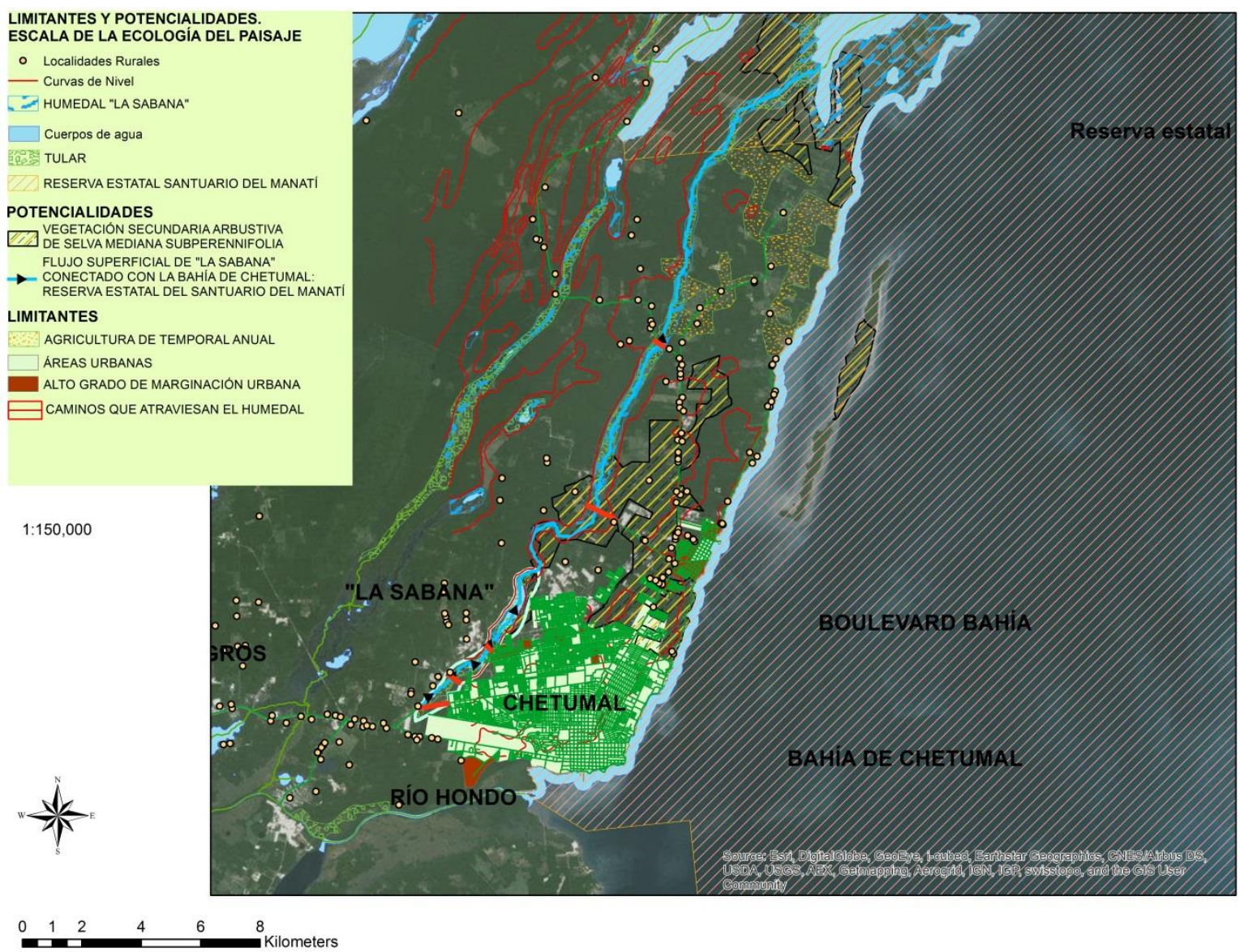


Figura 54. Mapa de Potencialidades y Limitantes de "La Sabana". Escala a nivel urbano-paisajístico

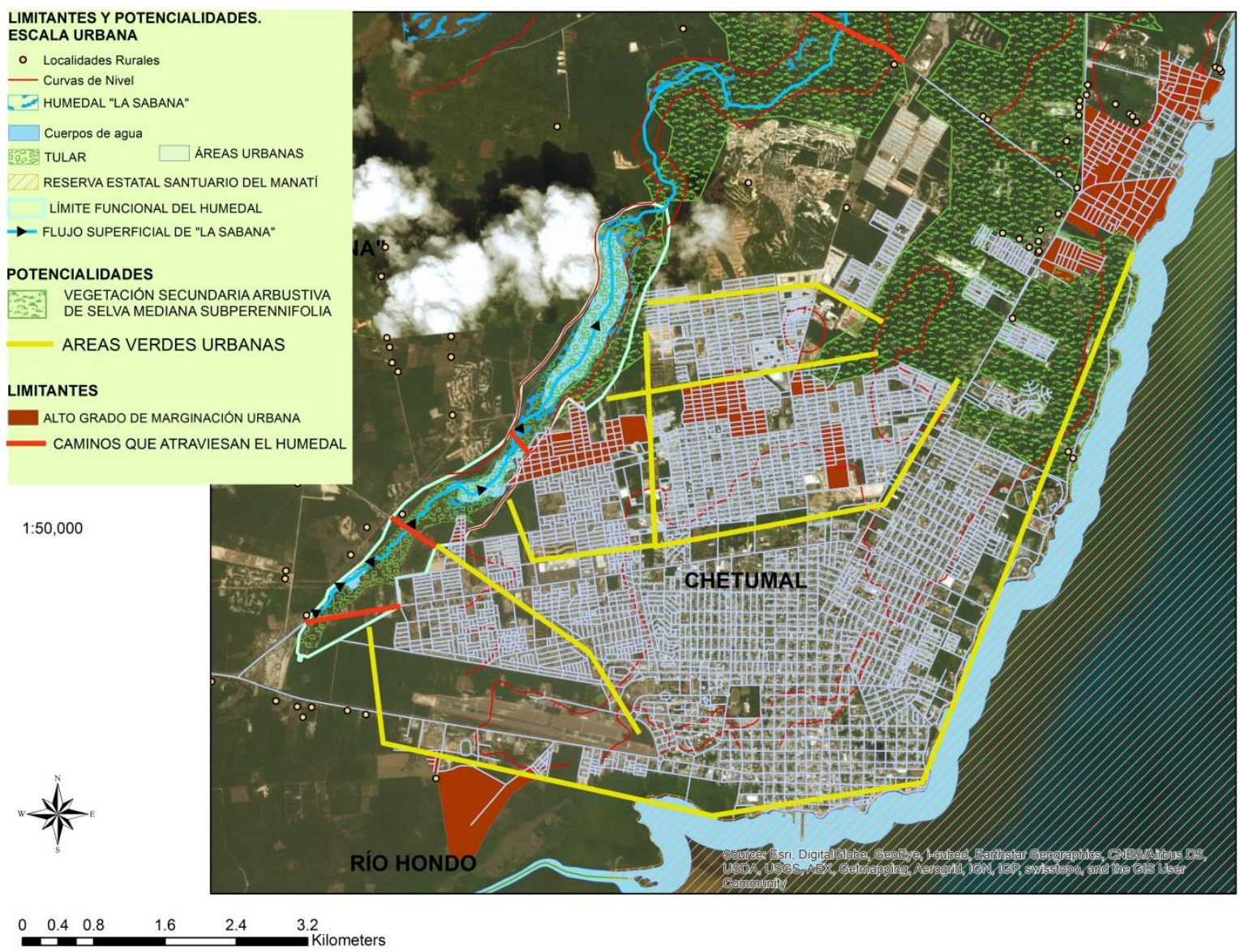


Figura 55. Mapa de Potencialidades y Limitantes de "La Sabana". Escala de relación urbana paisajística con el humedal "La Sabana".

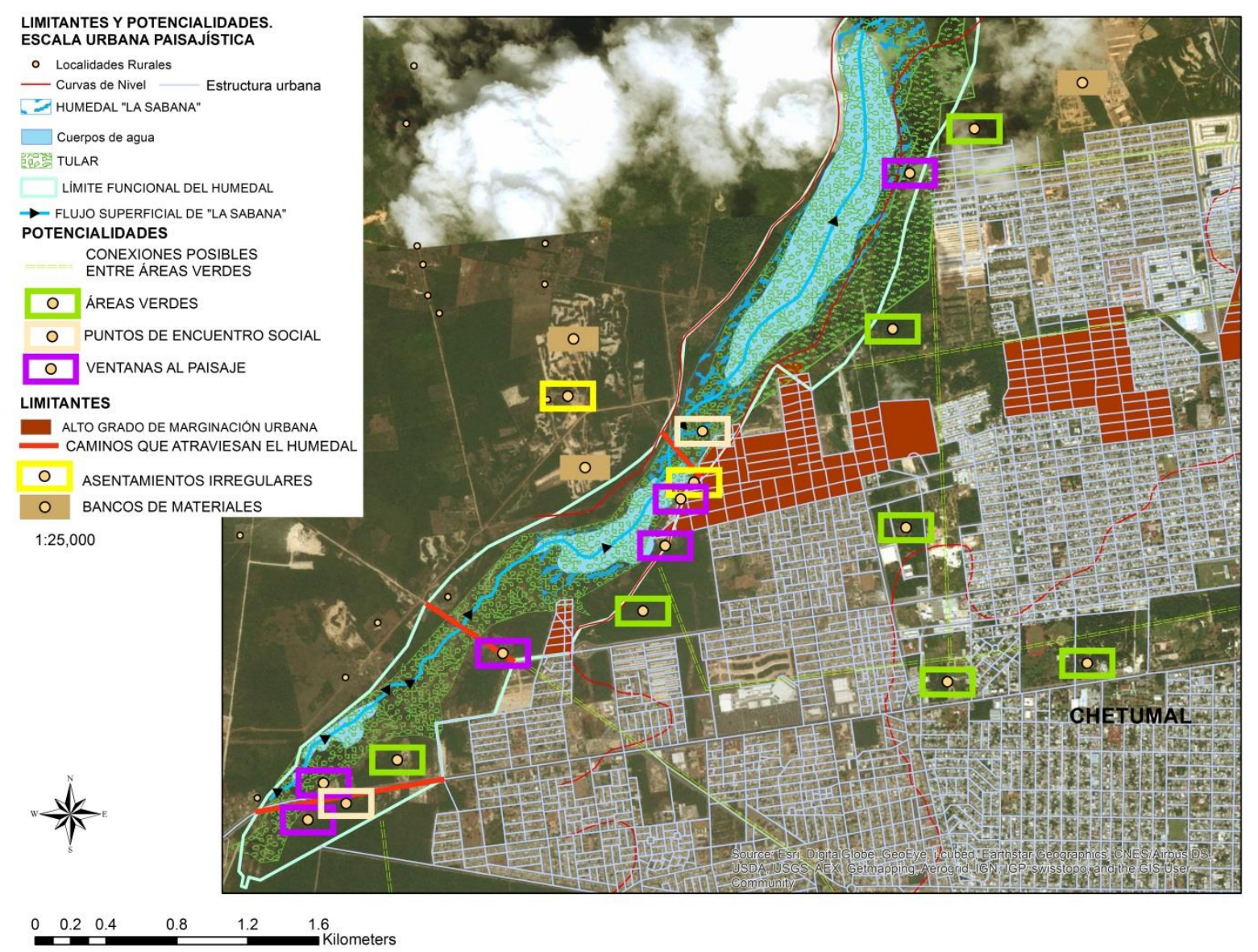

\subsection{Escenarios de desarrollo}

\subsubsection{Escenario tendencial}

El escenario tendencial es aquel futuro esperado de continuar las cosas como se han presentado hasta el momento sin que haya cambios significativos positivos para las problemáticas identificadas. En este sentido se espera que se incrementen las afectaciones al humedal por contaminación, rellenos, peligros sanitarios, peligros por inundación, mayor número de asentamientos irregulares, falta de infraestructura, inseguridad social e incertidumbre sobre los usos del suelo. Este escenario visualiza la contaminación, destrucción y eventual desaparición del humedal, debido a la presión del actual modelo de crecimiento urbano y sus implicaciones en el medio ambiente. 


\subsubsection{Escenario Deseable}

Este escenario es aquel al que se aspiraría llegar si las condiciones económicas, sociales, de conciencia y cuidado al medio ambiente y hacia el paisaje son más favorables. Bajo este esquema se esperaría que:

El humedal "La Sabana" está bajo el régimen de protección ambiental, al cuidado y resguardo de la SEMARNAT, y con la participación del Estado y del Municipio; cuenta con recursos de los tres órdenes de gobierno para su gestión, cuidado, preservación y mejoramiento. La población reconoce y valora los servicios ambientales y culturales que aporta a la ciudad, y es un espacio de disfrute, recreo y contemplación, además participa en las labores de protección del humedal. Por este motivo se ha inhibido el desarrollo urbano en las inmediaciones del humedal para conservar la capacidad de infiltración del suelo, preservar la vegetación original y proteger el humedal como reservorio de agua para el futuro y hábitat de fauna silvestre. Se inician además las gestiones para integrarlo a la red de humedales de la convención internacional RAMSAR.

\subsubsection{Escenario posible}

Este escenario surge a partir de la probabilidad de la confluencia de los intereses económicos, políticos, sociales, ambientales, paisajísticos y urbanos de la zona en estudio. Por este motivo se tiene en cuenta las aspiraciones vertidas en el Programa de Desarrollo Urbano para la Ciudad de Chetumal, así como el resultado de las encuestas realizadas en el capítulo anterior, en el cual se plantea la zona del humedal como parque urbano ecológico, recinto de equipamientos e infraestructuras para la educación ambiental y cultural, y que a través de este mismo instrumento (PDU, 2018) junto con el Plan Maestro Urbano Paisajístico para el humedal "La Sabana" se pueda ordenar e instrumentar dicho escenario.

\subsection{Imagen objetivo}

Con base en el análisis de los tres escenarios planteados este trabajo de investigación formula la imagen objetivo a la que se quiere llegar, a efecto de procurar la conservación 
ambiental y paisajística del humedal en un marco de desarrollo armónico con el crecimiento urbano de la ciudad de Chetumal.

"El humedal "La Sabana", es un área donde se reconoce el paisaje cultural, se realizan actividades recreativas, deportivas, de educación ambiental, senderismo y avistamiento de aves, entre otras. Se han desarrollado y modernizado las redes municipales de infraestructura sanitaria de drenaje municipal, lo que ha permitido regular las descargas de las aguas residuales provenientes de la planta de tratamiento, así como controlar su calidad. El humedal ha recuperado su funcionamiento natural, rediseñando y mejorando los caminos que lo cruzan, se han abierto nuevas ventanas al paisaje y las ya existentes se han enfatizado; de la misma manera se han instalado plataformas con construcciones tradicionales en palafitos que aguardan espacios que sirven para la vigilancia del humedal como museos, recintos de descanso, miradores y cafeterías. Es común ver a la gente paseando en los alrededores y en los paseos peatonales que se han instalado para el público, bien iluminados, con bancas y botes de basura, hay plazoletas con exposiciones y muestras de artistas locales que son muy concurridas, existen quioscos que ofrecen alimentos y bebidas y la comunidad se ha beneficiado con el desarrollo del humedal, pues se han consolidado las infraestructuras y los servicios urbanos. Los asentamientos en riesgo han sido reubicados a zonas aptas, y las áreas verdes inundables han sido acondicionadas con construcciones palafíticas que rememoran el folclor de la región mediante la resignificación de sus valores arquitectónicos y cromáticos y en ellas se concentran servicios para el recreo, el ocio y el comercio de abasto barrial. Se ha permitido el desarrollo urbano de baja densidad, con regulaciones estrictas sobre el manejo de las áreas verdes con cobertura vegetal original. Se han instaurado corredores de paisaje que unen las áreas verdes urbanas de Chetumal con el humedal y zonas aledañas, además del corredor del Boulevard Bahía, consolidándose "La Sabana" como parte del recorrido de paseo que realizan los Chetumaleños para su recreo y descanso, donde realiza caminatas, paseos en bicicleta y es un punto de encuentro para la Ciudad". 
Esta imagen objetivo concilia los intereses de los agentes sociales interesados e involucrados en la conservación y preservación del humedal guiándose por la visión que se tiene en la política pública urbana, ambiental y paisajística de la zona, misma que contempla un uso adecuado del humedal sin afectar su funcionamiento e integrado a las condiciones de desarrollo urbano y social de la ciudad de Chetumal.

\section{CAPÍTULO 5. LINEAMIENTOS AMBIENTALES, URBANOS, PAISAJíSTICOS $Y$ SOCIALES PARA EL HUMEDAL "LA SABANA"}

Para definir los lineamientos ambientales, urbanos, paisajísticos y sociales para el humedal "La Sabana" primero se establecieron los objetivos que se quiere lograr.

\subsection{Objetivos ambientales, urbanos, paisajísticos y sociales}

Definir los objetivos que se quieren lograr en términos ambientales, urbanos, paisajísticos y sociales, permitirá orientar los lineamientos y el curso de acción para establecer una zonificación con base en lo establecido en el reglamento para el establecimiento de Áreas Naturales Protegidas y posteriormente definir el Plan Maestro; a partir de lo cual se establecen los siguientes Objetivos:

\section{Objetivos ambientales:}

- Promover la incorporación del humedal "La Sabana" como ANP

- Preservar la integridad funcional del ecosistema

- Preservar los servicios ambientales generados

- Recuperar la calidad del agua de "La Sabana"

\section{Objetivos urbanos:}

- Generar la continuidad y conectividad urbana entre el humedal y la ciudad

- Facilitar la movilidad y accesibilidad peatonal y ciclista

- Regular los asentamientos humanos 


\section{Objetivos paisajísticos:}

- Preservar las masas densas de vegetación en buen estado de conservación en el perímetro del humedal

- Conservar y Promover la vegetación nativa del lugar

- Facilitar la accesibilidad visual al humedal para su conocimiento, contemplación y disfrute

\section{Objetivos sociales:}

- Generar puntos de encuentro social

- Facilitar la relación de uso entre la sociedad y el humedal

- Fomentar las actividades compatibles: socioeconómicas, culturales, recreativas, turísticas y de uso tradicional, con el humedal

- Promover una cultura de los humedales que permita su valoración y conlleve a su protección y cuidado

\subsection{Lineamientos ambientales, urbanos, paisajísticos y sociales para el humedal}

"La Sabana"

Para el logro de los objetivos propuestos se definieron lineamientos ambientales, urbanos, paisajísticos y sociales para el humedal "La Sabana". 


\section{Cuadro 6. Lineamientos ambientales, urbanos, paisajísticos y sociales para el humedal "La Sabana"}

\section{OBJETIVOS}

\section{AMBIENTALES}

- Promover la incorporación del humedal "La Sabana" como ANP

- Preservar la integridad funcional del ecosistema

- Preservar los servicios ambientales y su calidad

- Recuperar la calidad del agua de "La Sabana"

\section{URBANOS}

- Generar la continuidad y conectividad urbana entre el humedal y la ciudad

- Facilitar la movilidad y accesibilidad peatonal y ciclista

- Regular los asentamientos humanos

\section{PAISAJÍSTICOS}

- Preservar las masas densas de vegetación en buen estado de conservación en

\section{LINEAMIENTOS}

Incorporar el humedal "La Sabana" como Área Natural Protegida por presentar especial relevancia en los servicios Ambientales generados, así como preservar la integridad funcional del ecosistema

Establecer corredores de recursos (selvas de galería) o de ribera en el perímetro del humedal.

Permitir y regular el aprovechamiento sustentable de agroecosistemas, siempre y cuando no generen un impacto o alteración a la calidad del agua, vegetación y suelo, y que no interrumpan el funcionamiento natural del humedal.

Establecer una zonificación para los diferentes usos y actividades, que permitan preservar las condiciones óptimas del humedal en concordancia con las actividades humanas y urbanas de la ciudad.

Regular la descarga de aguas residuales tratadas sobre el humedal.

Demoler los caminos de terracería que atraviesan el humedal.

Establecer $u$ ordenar las vialidades entre la sabana y la ciudad que permitan la relación funcional y su acceso

Establecer interconexión de vialidades que permitan y faciliten la movilidad peatonal y de ciclistas hacia y en derredor del humedal

Incorporar los Asentamiento Humanos a un programa de regularización y dotación de servicios públicos como agua potable, drenaje y energía eléctrica.

Prohibir los nuevos asentamientos en las riberas del humedal y dentro de un área de amortiguamiento definida previamente.

Establecer un reglamento de imagen urbana y arquitectónica que integre los sistemas constructivos tradicionales incluyendo los colores característicos de la arquitectura caribeña del sitio.

Establecer zonas de uso restringido para la conservación de masas forestales que permitan servicios ambientales y culturales 
las inmediaciones del humedal

- Conservar y Promover la vegetación nativa del lugar

- Facilitar la accesibilidad visual al humedal para su conocimiento, contemplación y disfrute

\section{SOCIALES}

- Generar puntos de encuentro social

- Facilitar la relación de uso entre la sociedad y el humedal

- Orientar las actividades compatibles: socioeconómicas, culturales, recreativas, turísticas y de uso tradicional, con el humedal

- Promover una cultura de los humedales que permita su valoración y conlleve a su protección y cuidado

\section{DE RELACION AMBIENTAL, URBANO Y PAISAJÍSTICA}

Regular el manejo de la vegetación nativa original del sitio.Promover el uso de vegetación nativa para su uso en camellones, banquetas, remanentes y áreas verdes urbanas Establecer nodos que permitan una ventana al paisaje y que faciliten el acceso visual hacia "La Sabana"

Establecer nodos como plazas y parques que permitan y faciliten las relaciones sociales y el aprovechamiento del espacio público

Permitir y regular las actividades de bajo impacto compatibles con el humedal

Establecer una zonificación para los diferentes usos y actividades, que permitan preservar las condiciones óptimas del humedal en concordancia con las actividades humanas y urbanas de la ciudad.

Establecer un programa cultural de divulgación y difusión en las intermediaciones del humedal, con la participación del gobierno, asociaciones civiles y público en general

Establecer corredores verdes que permitan la integración funcional, visual, paisajística, ambiental y urbana entre el humedal "La Sabana" y la Ciudad de Chetumal.

\subsection{Zonificación y subzonas del humedal "La Sabana"}

Para la propuesta de zonificación de "La Sabana", se tomó como referencia el Reglamento de la Ley General del Equilibrio Ecológico y la Protección al Ambiente en materia de Áreas Naturales Protegidas, relativo al Establecimiento, Administración y Manejo de las Áreas Naturales Protegidas de competencia de la Federación, Artículo 49: de las Declaratorias para el Establecimiento de Áreas Naturales Protegidas. 
En ellas se establece que "en relación al establecimiento y manejo de las áreas naturales protegidas se realizará una subdivisión que permita identificar y delimitar las porciones del territorio que la conforman, acorde con sus elementos biológicos, físicos y socioeconómicos, los cuales constituyen un esquema integral y dinámico, por lo que cuando se realice la delimitación territorial de las actividades en las áreas naturales protegidas, ésta se llevará a cabo a través de las siguientes zonas y sus respectivas subzonas, de acuerdo a su categoría de manejo:

I. Las zonas núcleo, que tendrán como principal objetivo la preservación de los ecosistemas a mediano y largo plazo, y que podrán estar conformadas por las siguientes subzonas:

a) De protección: Aquellas superficies dentro del área natural protegida, que han sufrido muy poca alteración, así como ecosistemas relevantes o frágiles y fenómenos naturales, que requieren de un cuidado especial para asegurar su conservación a largo plazo, y

b) De uso restringido: Aquellas superficies en buen estado de conservación donde se busca mantener las condiciones actuales de los ecosistemas, e incluso mejorarlas en los sitios que así se requieran, y en las que se podrán realizar excepcionalmente actividades de aprovechamiento que no modifiquen los ecosistemas y que se encuentren sujetas a estrictas medidas de control.

II. Las zonas de amortiguamiento, tendrán como función principal orientar a que las actividades de aprovechamiento, que ahí se lleven a cabo, se conduzcan hacia el desarrollo sustentable, creando al mismo tiempo las condiciones necesarias para lograr la conservación de los ecosistemas de ésta a largo plazo, y podrán estar conformadas básicamente por las siguientes subzonas: 
a) De uso tradicional: Aquellas superficies en donde los recursos naturales han sido aprovechados de manera tradicional y continua, sin ocasionar alteraciones significativas en el ecosistema. Están relacionadas particularmente con la satisfacción de las necesidades socioeconómicas y culturales de los habitantes del área protegida;

\section{b) De aprovechamiento sustentable de los recursos naturales:} Aquellas superficies en las que los recursos naturales pueden ser aprovechados, y que, por motivos de uso y conservación de sus ecosistemas a largo plazo, es necesario que todas las actividades productivas se efectúen bajo esquemas de aprovechamiento sustentable;

c) De aprovechamiento sustentable de agroecosistemas: Aquellas superficies con usos agrícolas y pecuarios actuales;

d) De aprovechamiento especial: Aquellas superficies generalmente de extensión reducida, con presencia de recursos naturales que son esenciales para el desarrollo social, y que deben ser explotadas sin deteriorar el ecosistema, modificar el paisaje de forma sustancial, ni causar impactos ambientales irreversibles en los elementos naturales que conforman;

e) De uso público: Aquellas superficies que presentan atractivos naturales para la realización de actividades de recreación y esparcimiento, en donde es posible mantener concentraciones de visitantes, en los límites que se determinen con base en la capacidad de carga de los ecosistemas

f) De asentamientos humanos: En aquellas superficies donde se ha llevado a cabo una modificación sustancial o desaparición de los 
ecosistemas originales, debido al desarrollo de asentamientos humanos, previos a la declaratoria del área protegida, $y$

g) De recuperación: Aquellas superficies en las que los recursos naturales han resultado severamente alterados o modificados, y que serán objeto de programas de recuperación y rehabilitación."

Para la propuesta de zonificación de "La Sabana", convendría reconocer dos zonas principales: el cuerpo permanente de agua que colinda con la ciudad, y el área de escorrentía y flujo de drenaje natural hacia la Bahía de Chetumal que colinda con rancherías y zonas naturales en buen estado de conservación; y que en el sentido de la definición de humedales RAMSAR, estos deberían ser considerados como parte integral de la Bahía, como parte de su zona ribereña adyacente, y en este sentido, para su protección y salvaguarda, sería conveniente incorporarlo en el ANP Estatal de la "Reserva Estatal Santuario del Manatí", y posteriormente realizar las gestiones para que este último forme parte de los humedales RAMSAR. Sin embargo, hay que considerar el interés creciente por parte del municipio de Othón P. Blanco por el humedal que colinda con el área urbana, por lo que existe la posibilidad de delimitar un ANP cuasi independiente en términos de su Gestión y Manejo, cuya categoría de acuerdo al Reglamento del Equilibrio Ecológico y la Protección al Ambiente para el Municipio de Othon P. Blanco sería de Zona de Preservación Ecológica del Centro de Población de Chetumal. (Figura 56).

\footnotetext{
${ }^{53}$ Reglamento de la Ley General del equilibrio ecológico y la protección al ambiente en materia de Áreas Naturales Protegidas, última reforma 2014.
} 
Figura 56. Propuesta de incorporación del humedal "La Sabana" al ANP Estatal "Reserva estatal el santuario del Manatí".

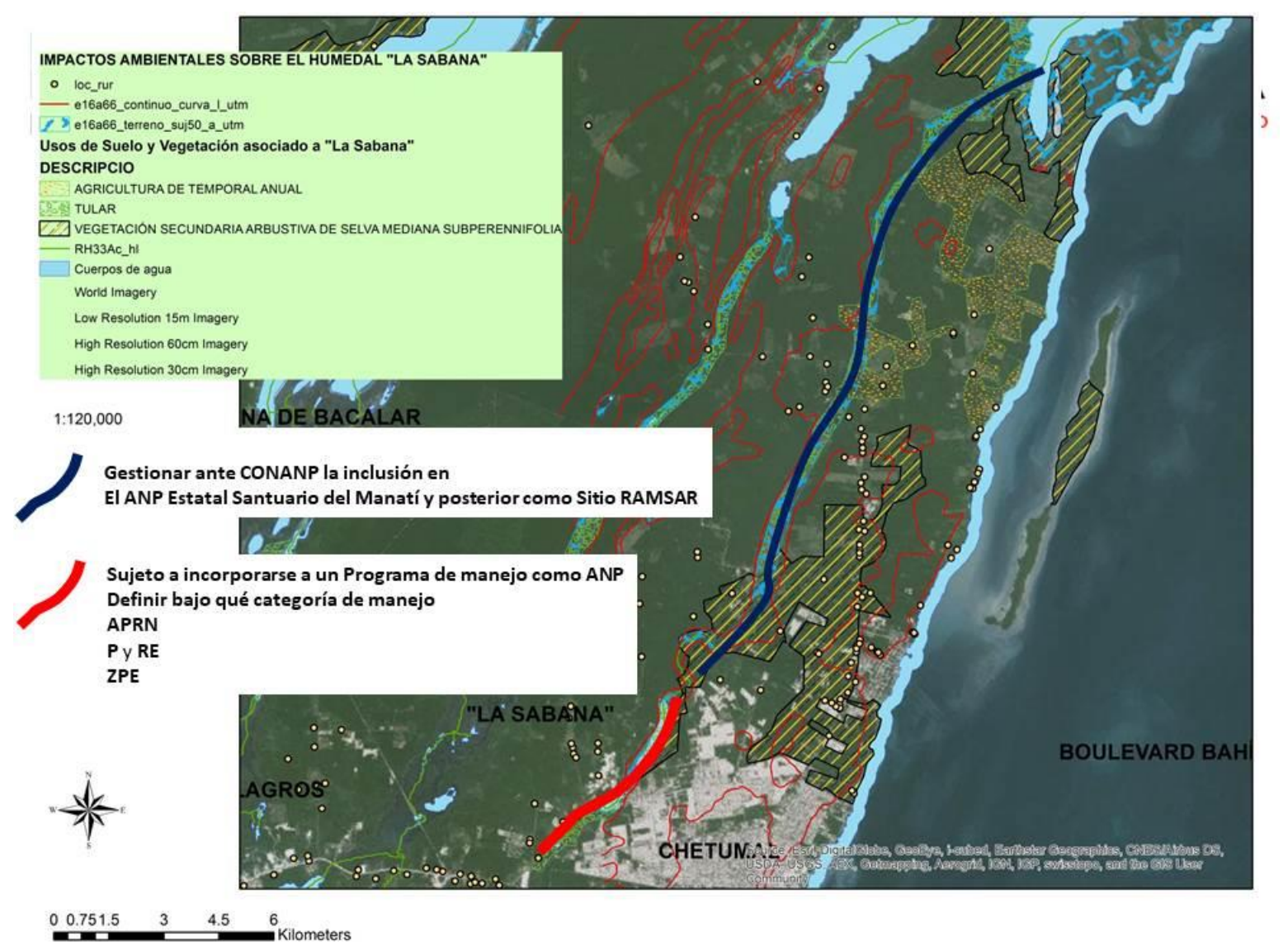

En términos de una zonificación para su manejo se estableció la siguiente zonificación general (figura 57), de la cual se desprenderán sub zonas, que podrán observarse en planos de mayor detalle. 
Figura 57. Zonificación General para el manejo del humedal "La Sabana"

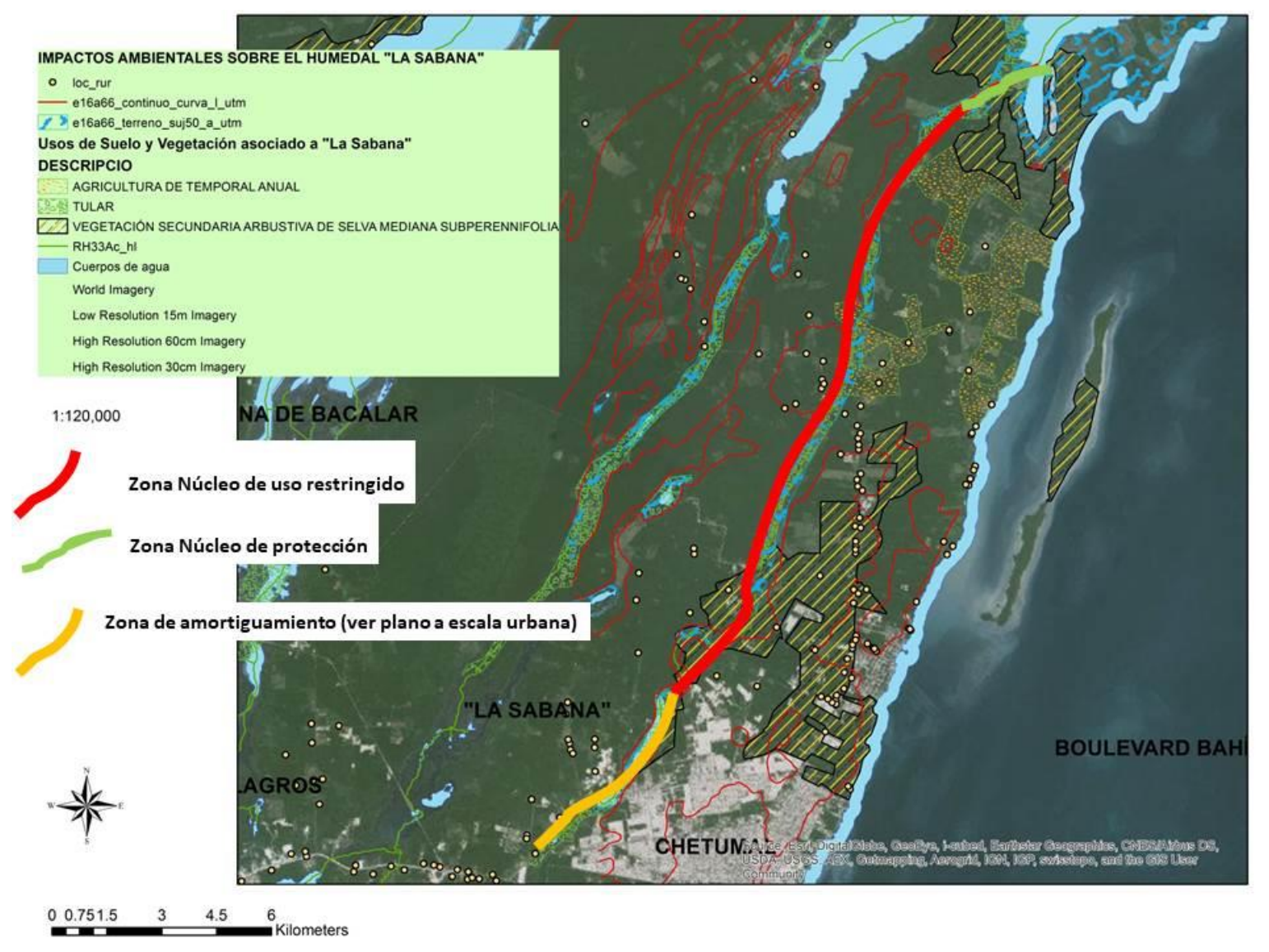

Por su parte para el cuerpo de agua permanente se propone la siguiente zonificación inicial (Figura 58). 


\section{Figura 58. Zonificación preliminar "La Sabana"}

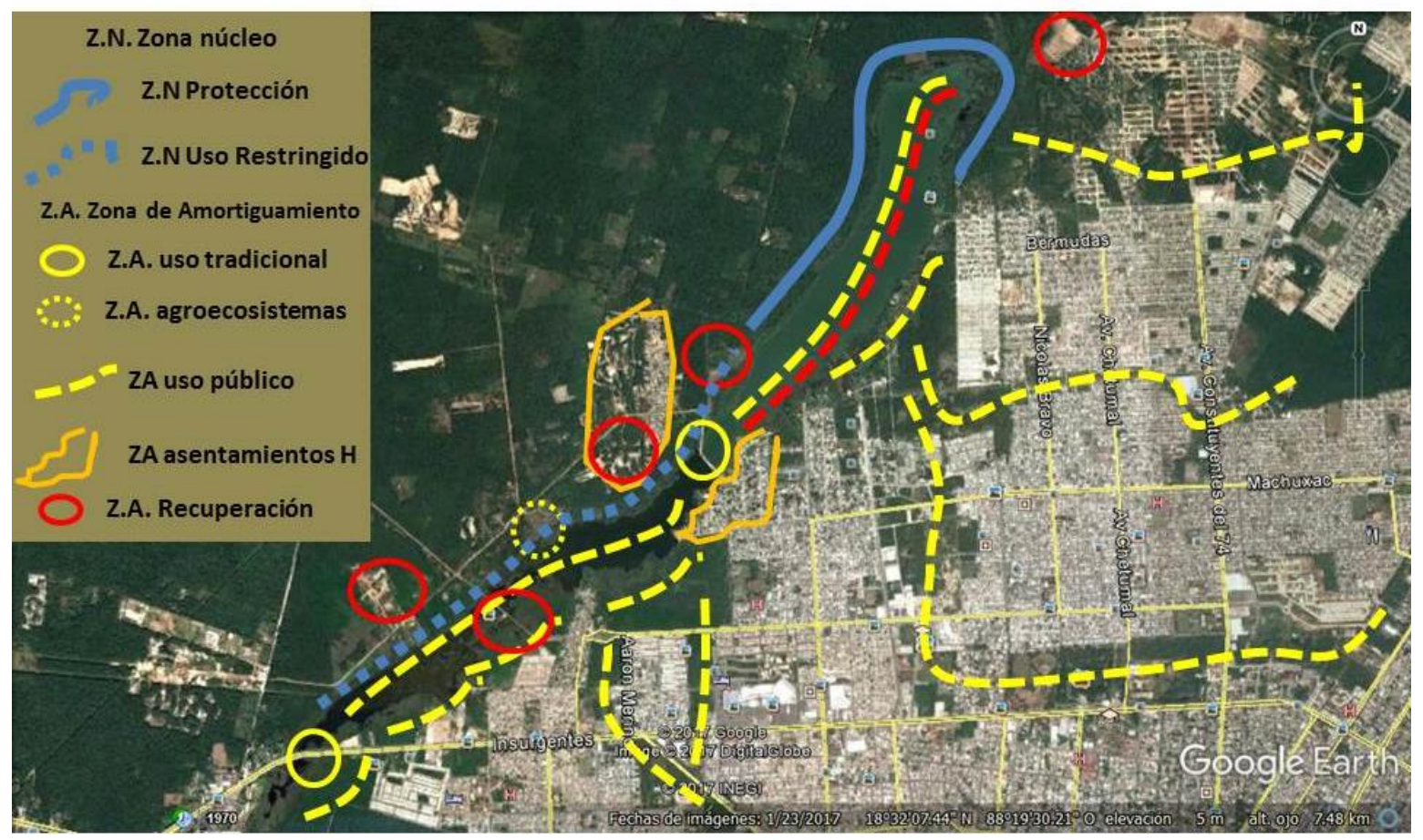

Para establecer la zonificación al interior del humedal, fue necesario trabajar a otra escala de trabajo, sobreponiendo las capas de Usos de Suelo y Vegetación del INEGI, Edafología, Topografía, Cuerpos de agua, Zonas de inundación, que permitieron identificar zonas que compartían rasgos en común y de este modo definir una zonificación primaria.

Se realizaron diferentes procesos geográficos: con los polígonos de zonas de inundación, cuerpos de agua y vegetación de tipo tular, se unieron para definir el área específica del humedal, mientras que con el polígono de vegetación (vegetación secundaria arbustiva y vegetación secundaria arbórea), la topografía, la imagen satelital y los recorridos de campo se identificaron y definieron áreas en buen estado de conservación con los cuales se tomaron los siguientes: 


\section{Criterios de zonificación:}

1. Al polígono del humedal se le asignó un área de amortiguamiento o de influencia (buffer) de 50 metros con la finalidad de preservar la selva de galería; se le asigno como Zona Núcleo de Protección: ZN-PRO

2. Las áreas adyacentes con la línea de escorrentía superficial del humedal que desemboca hacia la bahía de Chetumal, se consideró Zona Núcleo de Protección: ZN-PRO

3. Las áreas verdes en buen estado de conservación que quedaron dentro del polígono de la limitación del humedal se les asignó como Zona Núcleo de Uso Restringido: ZN-UR

4. Las zonas urbanas que colindan con el polígono del humedal se les asignó como Zona de Amortiguamiento de Uso Público, donde se podrán establecer áreas verdes urbanas como parques, jardines, y equipamiento cultural, educativo y recreativo de bajo impacto: ZA-UP

5. Las zonas donde se concentra la población para realizar actividades de pesca recreativa y de autoconsumo, se le asignó Zona de Amortiguamiento de Uso Tradicional: ZA-UT

6. Las zonas donde se realizaron caminos de terracería que afectan el funcionamiento del humedal, se le asignó Zona de Amortiguamiento de Recuperación: ZA-REC

7. Las áreas urbanas que colinda directamente con el humedal se les asignó como Zona de Amortiguamiento de Asentamientos Humanos, cabe destacar que estos deberán estar sujetos a un programa de mejoramiento y regularización arquitectónica y urbana: $\mathrm{ZA}-\mathrm{AH}$

8. Dentro de las zonas anteriores que hayan tenido un impacto significativo en la configuración, funcionamiento y carácter paisajístico del humedal se procederá a un programa de recuperación, como Zona de Amortiguamiento de Recuperación: ZA-REC 
9. Por su parte al cuerpo de agua permanente del humedal se le asignó como Zona Núcleo de Uso Restringido, por lo cual las actividades que se realicen en él deben ser reguladas y controladas, se consideran usos compatibles de bajo impacto la pesca de autoconsumo y recreativa, el uso de kayaks o embarcaciones menores no motorizadas de uso recreativo, observación de aves y naturaleza, y usos con fines académicos: ZN-UR

Figura 59. Zonificación del humedal "La Sabana"

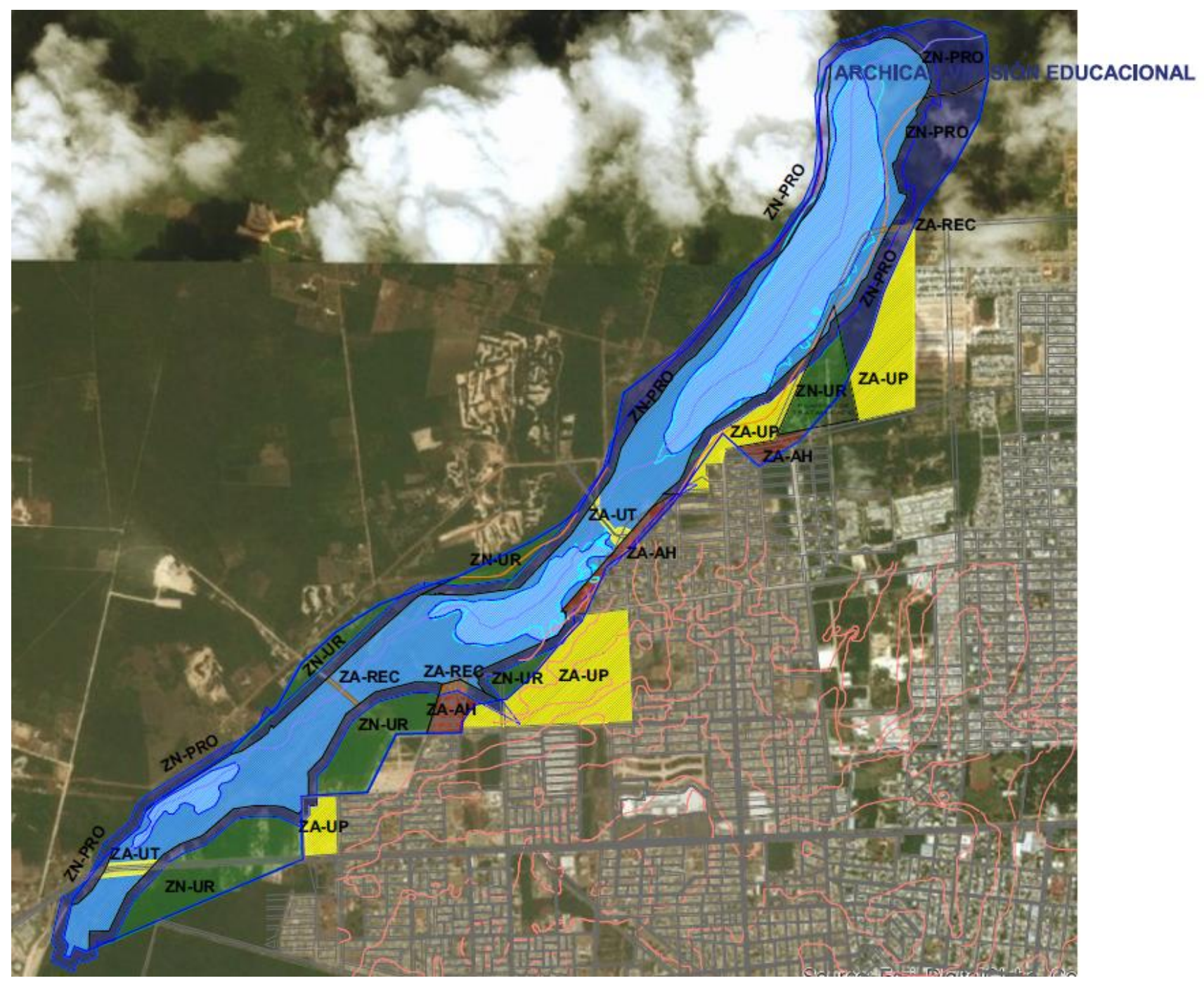

Fuente: Elaboración propia 


\subsection{Plan Maestro}

La elaboración del Plan Maestro contempló la definición de los siguientes proyectos estratégicos que dan estructura y coherencia a la relación urbana, paisajística y ambiental de la ciudad y el humedal:

1. Bulevar "La Sabana". Es un circuito urbano-paisajístico que facilita las conexiones entre las actividades recreativas, culturales, observación de aves y naturaleza, deporte de recreación y salud como ciclismo, caminata y atletismo. En este Bulevar se adecuarán las avenidas para fomentar la movilidad sustentable y la accesibilidad universal. Para ello se ubican dos pasos a desnivel para ciclistas y peatones.

2. La estructura paisajística y urbana de "La Sabana" es a través de tres parques distribuidos a lo largo del humedal, interconectados con bulevares y circuitos ciclistas y peatonales.

2.1 Parque "Sabana Sur". Este parque se encuentra en la entrada de Chetumal, entre las dos principales avenidas que dan acceso a la Ciudad. Ello brinda la oportunidad de mostrar la mejor imagen para el visitante y el Chetumaleño de "La Sabana" con un parque que integra servicios ambientales y culturales como quioscos de servicios, aparcamiento para autos y bicicletas, módulos de información, seguridad y primeros auxilios.

2.2 Parque "Sabana Norte", funge como Zona de Amortiguamiento entre la ciudad y el humedal, brindando servicios ambientales y culturales como quioscos de servicios, aparcamiento para autos y bicicletas, casetas de orientación, seguridad y primeros auxilios.

2.3 Parque Cultural "La Sabana", estratégicamente localizado al centro del humedal, entre los parques "Sabana Norte" y "Sabana Sur", donde se establecen equipamientos culturales, educativos y recreativos para el uso de toda la ciudad, está interconectado a través de bulevares y circuitos ciclistas y peatonales. 
3. Zonas de Amortiguamiento de Uso Tradicional; se definen tres zonas de este tipo donde la gente se reúne a pescar de manera recreativa; la primera está ubicada sobre Av. Insurgentes, la segunda en el puente que atraviesa el humedal, y se propone una tercera como punto de encuentro social y como remate visual de dos avenidas en la zona norte de "La Sabana". Estas zonas constituyen "ventanas al paisaje" del humedal, que permitirán a la gente estar en contacto y relacionarse con su espacio natural. Contará con iluminación, botes de basura, bancas y quioscos; en el caso del puente se instalará un parque para el recreo de la población de las colonias inmediatas.

4. Un aspecto importante del Plan Maestro es recuperar las zonas que han sido gravemente impactadas por el desarrollo urbano, por este motivo se propuso como Zona de Amortiguamiento de Recuperación uno de los caminos que atraviesa el humedal, se deberá de demoler para recuperar el funcionamiento natural del flujo de agua de "La Sabana".

5. Otra zona importante es la de Amortiguamiento de Asentamiento Humano, donde se proponen mejoramientos en la infraestructura, mobiliario e imagen urbana; en el área colindante con el puente se instalará un parque, y en donde colinda con el Parque Cultural, se construirá un bulevar cultural, que constará con áreas de exhibición al aire libre, quioscos tipo palafitos a manera de la arquitectura vernácula, mobiliario urbano, todo montado sobre una plataforma de madera que tiene como remate el humedal "La Sabana".

6. Fuera del polígono de "La Sabana" pero colindante en la cercanía se localiza un humedal de menor magnitud, que puede formar parte de este Plan Maestro, comunicándolo a través de vías para el senderismo.

7. Finalmente forma parte de este Plan Maestro, de manera indicativa, la vigilancia permanente sobre el humedal, las descargas de aguas residuales y sobre todo regular la planta de tratamiento de aguas residuales que vierte las aguas tratadas sobre el humedal. 


\section{Figura 60. Plan Maestro Paisajístico y Ambiental para el humedal "La Sabana"}

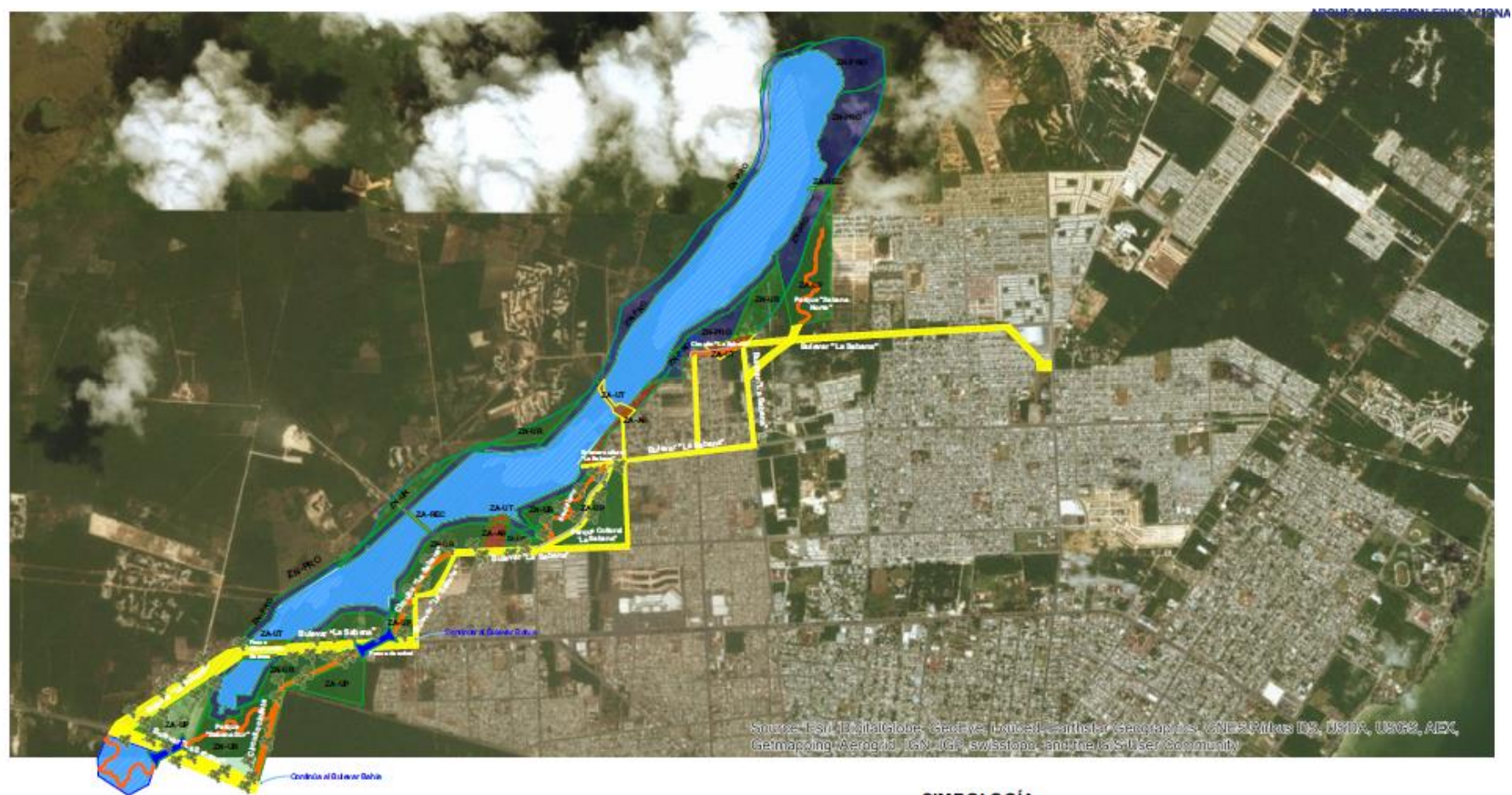

PLAN MAESTRO URBANO PAISAJISTICO PARAEL HUMEDAL "LA SABANA"

ELABORÓ: DANTE AHUIZOTL KOH ROMERO

ESPECIALISTA EN DISENO, PLANIFICACIÓN Y CONSERVACIÓN DE PAISAJES Y JARDINES

SIMBOLOGIA

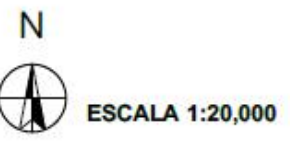

HUMEDAL "LA SABANA

SEIVADE GALERIA

AREAS VERDES: ZONAS NUCLEO DE USO RESTRINGDO Y ZONAS DE 作

ZONA DE AMORTIGUAMIENTO DE USO TRADICIONAL Y CULTURAL ZONA DE AMORTIGUAMIENTO DE RECUPERACIÓN

ZONA DE AMORTIGUAMIENTO DE ASENTAMIENTOS HUMANOS BULEVARES DE CONECTIVID AD Y MOVILIDAD

CIRCUITOS PARAMOVILIDAD PEATONAL, CICLISTAY ATLETISMO

RECREATNO PASOS A DESNIVEL PARA MOMLIDAD PEATONAL, CICLISTA Y ATLETISMO ESCALA 1:20,000

Fuente: Elaboración propia 
Figura 61. Plan Maestro Zona Sur "La Sabana"

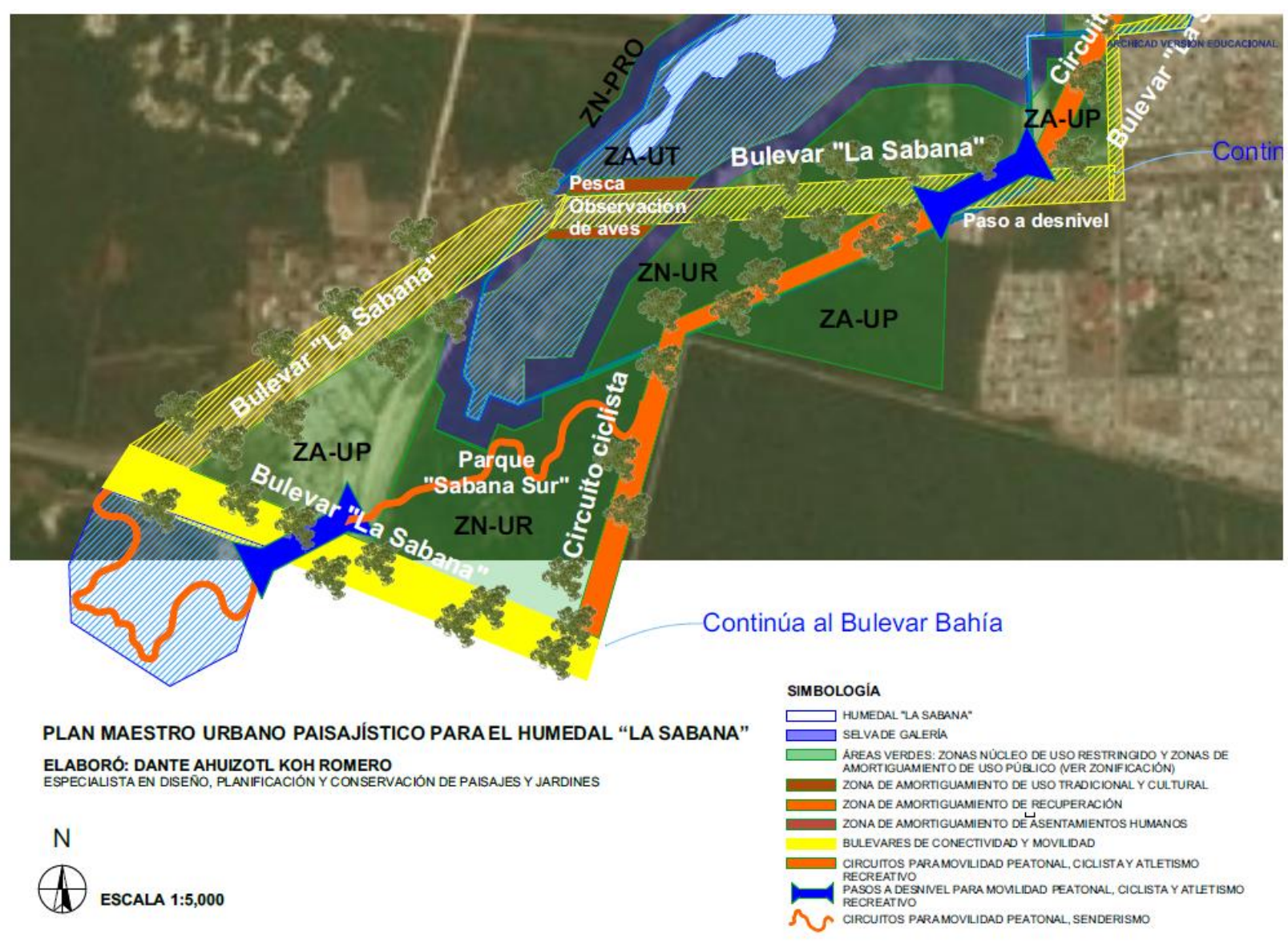


Figura 62. Plan Maestro Urbano Paisajístico y Ambiental "La Sabana" Centro

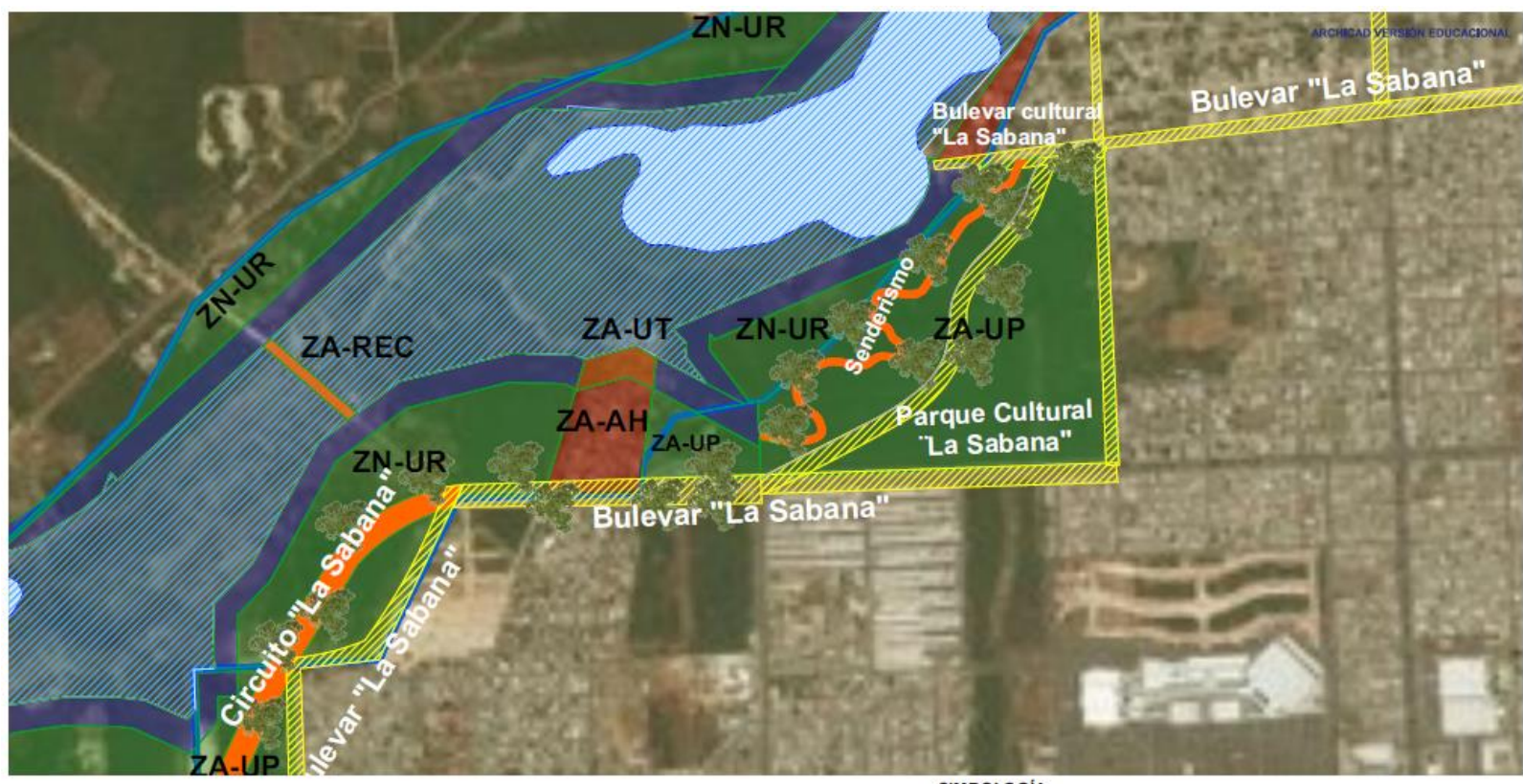
SIMBOLOGIA

PLAN MAESTRO URBANO PAISAJISTICO PARAEL HUMEDAL "LA SABANA"

ELABORÓ: DANTE AHUIZOTL KOH ROMERO

ESPECIALISTA EN DISEÑO, PLANIFICACIÓN Y CONSERVACIÓN DE PAISAJES Y JARDINES

$$
\theta \text { escala 1:5,000 }
$$

$\square$ HUMEDAL "LA SABANA"

SEVADE GNEPI

AREAS VERDES: ZONAS NUCLLOO DE USO RESTRINGDO Y ZONAS DE AMORA DEAMORTIGUAMENTO DE USO THA ZONADEAMOPTIGUAMIENTO DE RECUPERACION ZONA DE AMORTIGUAMIENTO DE ÁSENTAMIENTOS HUMANOS BULEVARES DE CONECTIVIDAD Y MOVILIDAD

CIRCUITOS PARAMOVILIDAD PEATONAL, CICLISTAY ATLETISMO PASOS ADESNIVEL PARA MOMLIDAD PEATONAL, CICLISTA YATLETISMO

S CIRCUITOS PARAMOVILIDAD PEATONAL, SENDERISMO 
Figura 63. Plan Maestro Urbano Paisajístico y Ambiental para el humedal "La Sabana", zona Norte

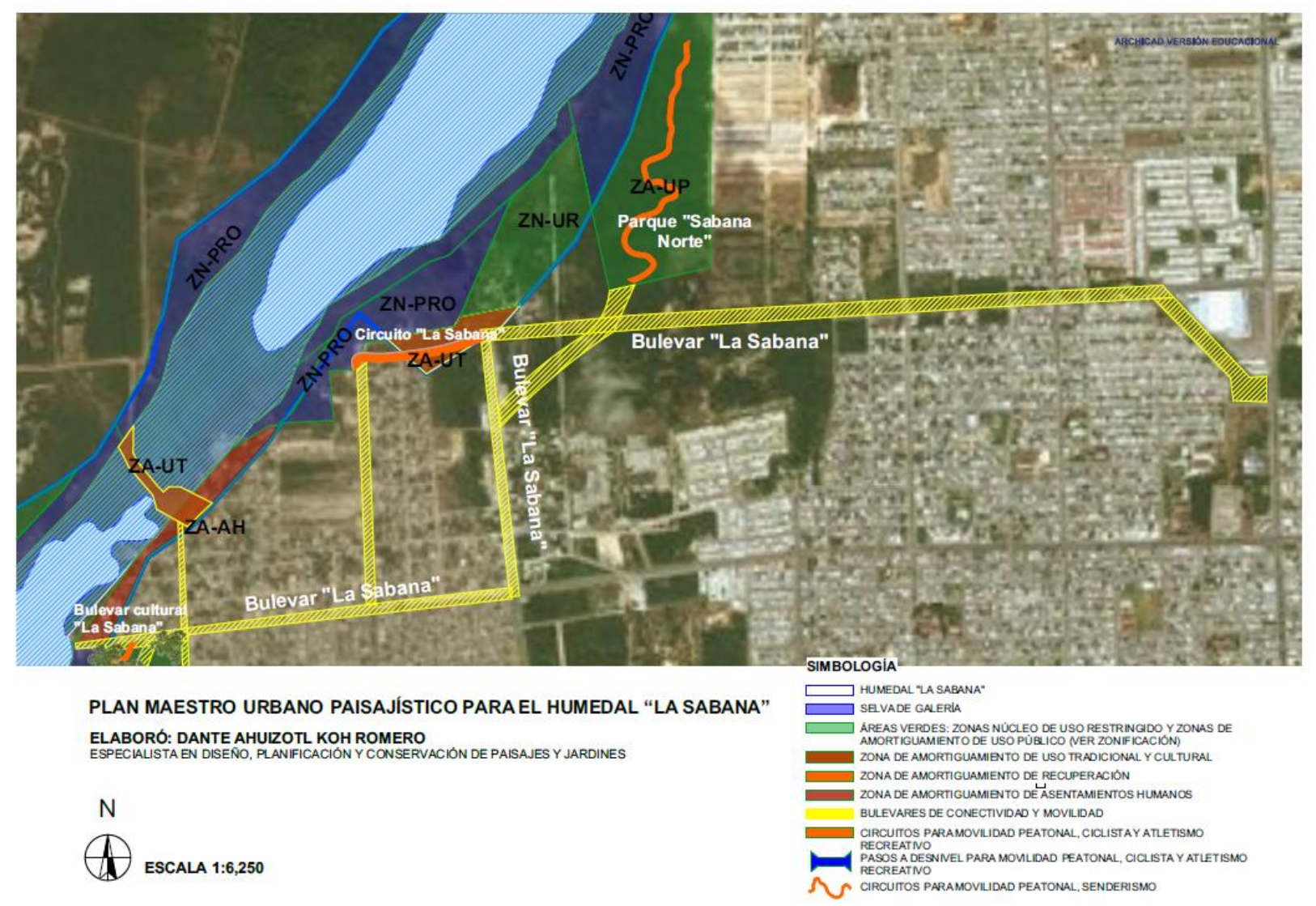


Figura 64. Plan Maestro Urbano Paisajístico y Ambiental para "La Sabana" Cabecera Norte
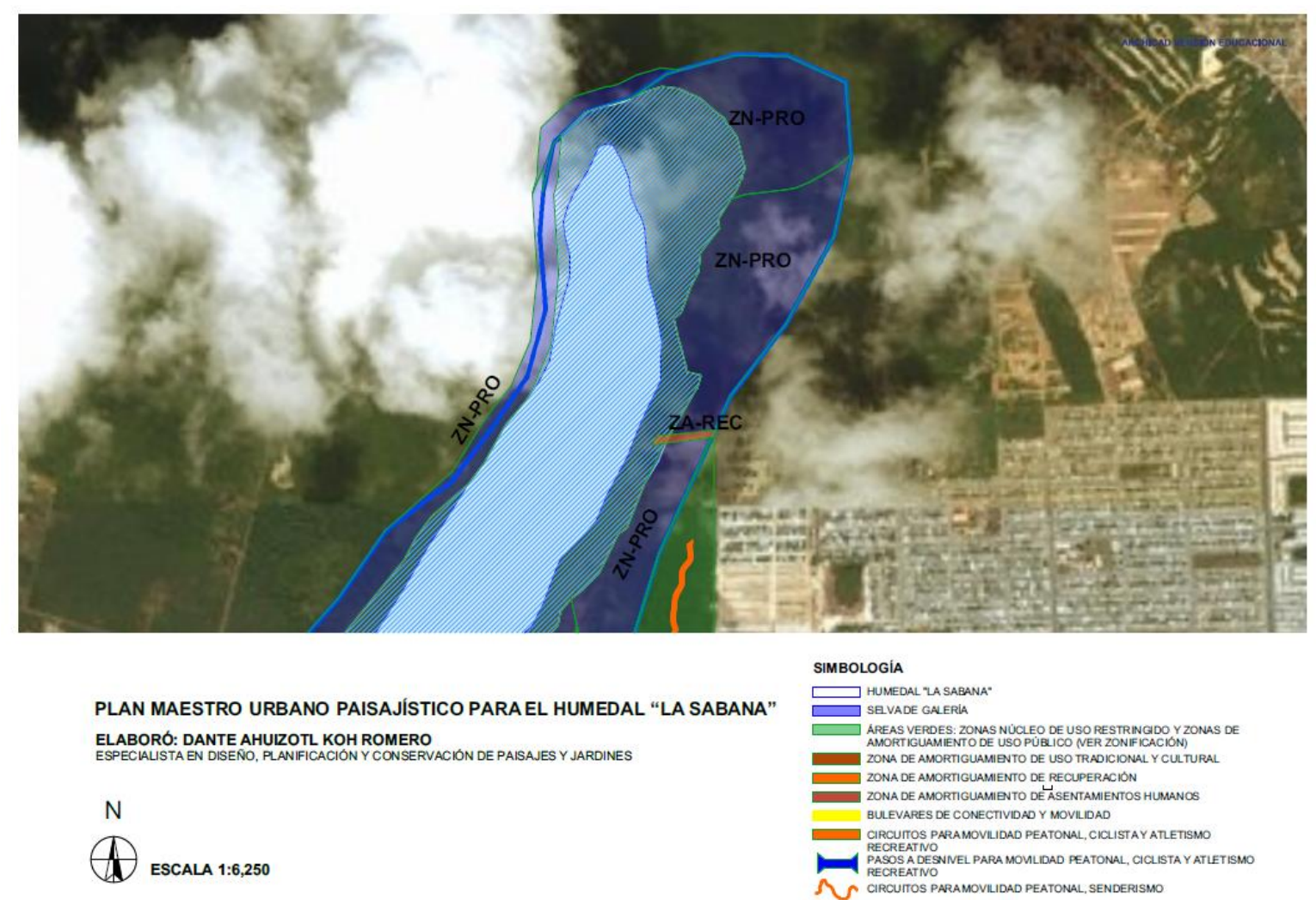

SIMBOLOGIA

$\square$ HUMEDAL "IA SABana"

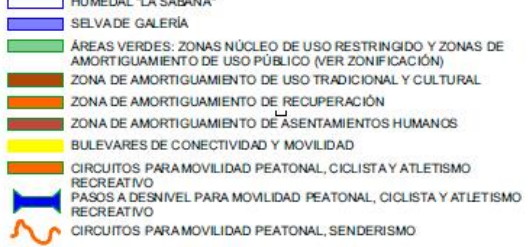




\subsection{Imágenes conceptuales}

Figura 65. Plan Maestro y actividades compatibles para el Humedal "La Sabana"

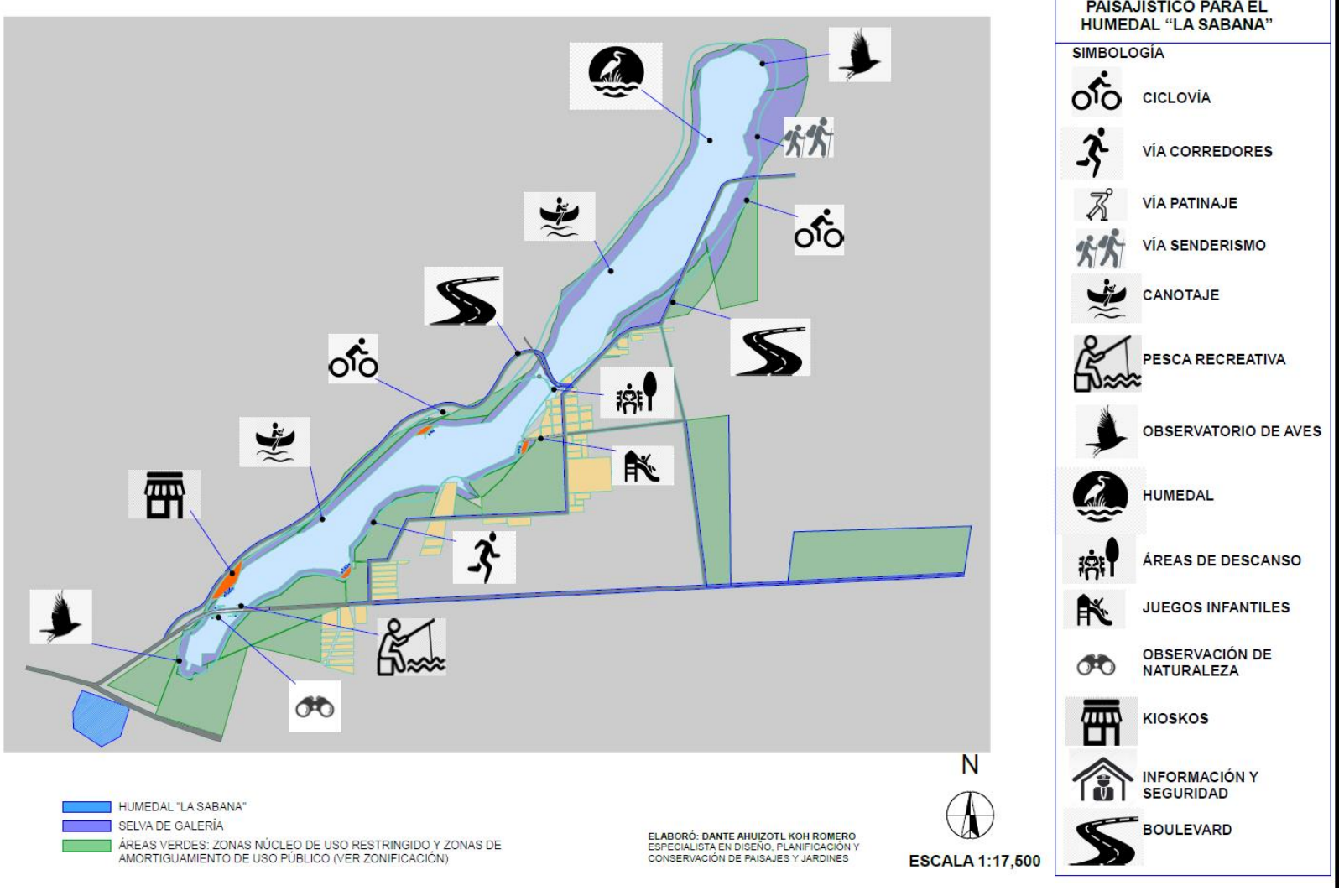

El humedal "La Sabana" integra actividades compatibles con su funcionamiento natural, rescatando los valores paisajísticos, culturales e identitarios del lugar. 
Figura 66. Proyectos estratégicos

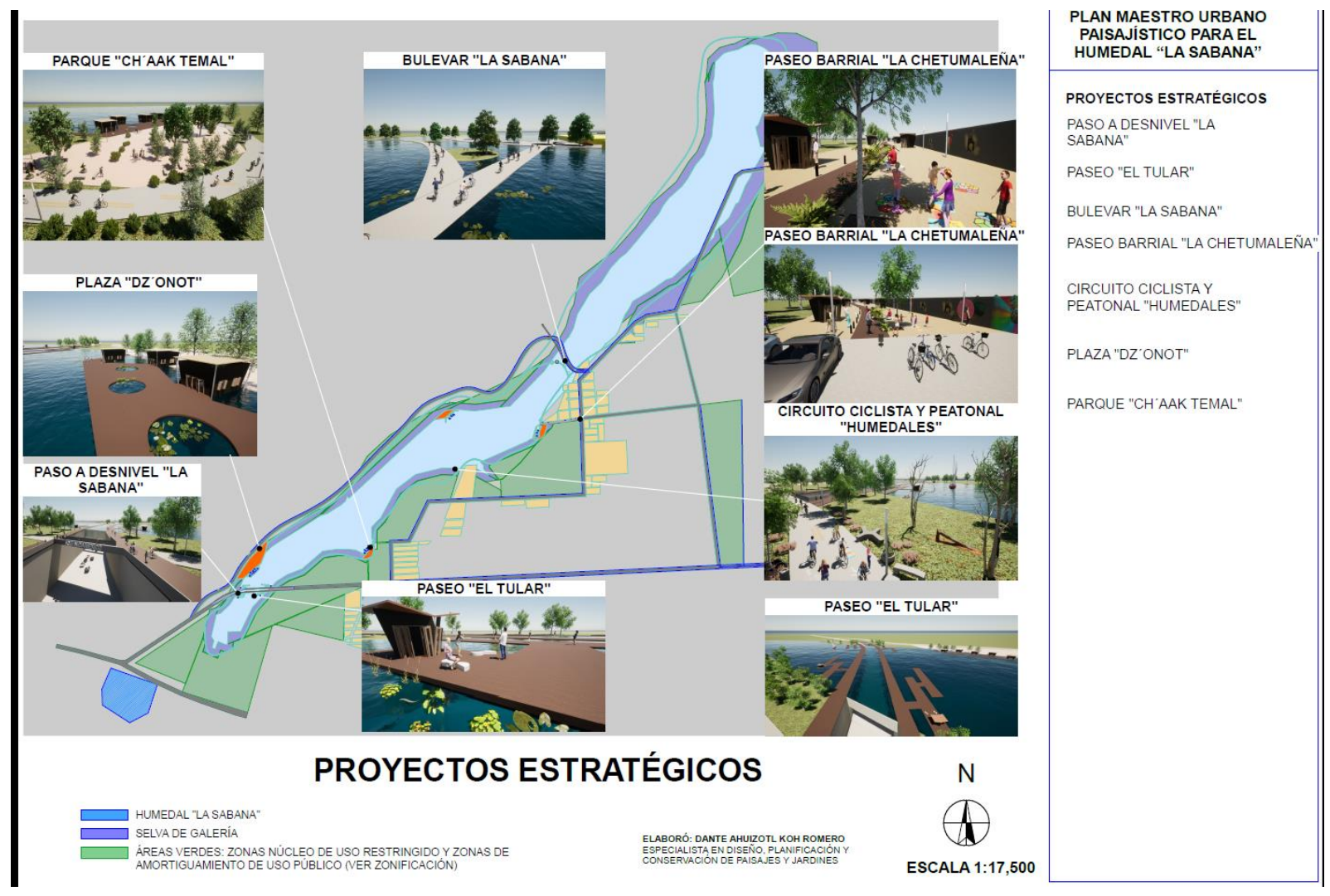

Los proyectos más emblemáticos para el humedal, enfatizan la relación cultural y fomentan una integración armónica entre el hombre y la naturaleza. Estos se distribuyen en derredor de "La Sabana" conectados por paseos, parques quioscos y rodeados de paisaje. 
Figura 67. Parque Ch'aak Temal

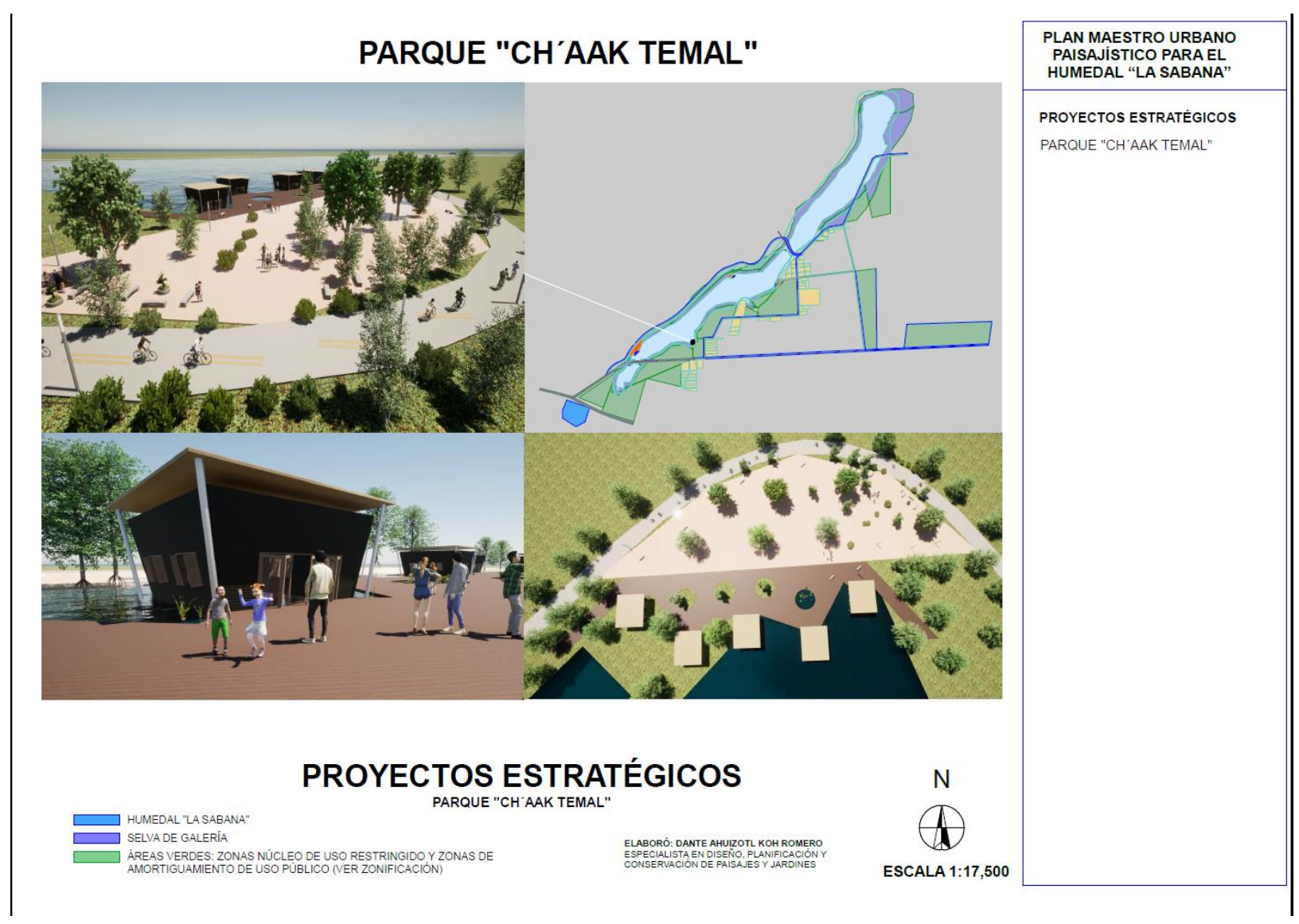

Este parque, lleva el nombre del asentamiento prehispánico que antecede a Chetumal, significa allí donde baja la lluvia o donde crecen los árboles rojos, se rescata además la identidad arquitectónica del lugar con estructuras que rememoran los palafitos y texturas y acabados en color madera. 
Figura 68. Paseo El Tular



Este paseo hace referencia a la vegetación de tipo tular que está asociada a los humedales y que tiene presencia en el lugar. Es un espacio de paseo que permite el disfrute del paisaje con áreas de descanso, quioscos, lugar de pesca recreativa, fotografía y paseo sobre una plataforma de madera, conocida como muelles, muy popular en la zona. La arquitectura contemporánea es una deconstrucción de la arquitectura vernácula del lugar, con cubiertas inclinadas a dos aguas a la inversa. 
Figura 69. Paso a Desnivel "La Sabana"

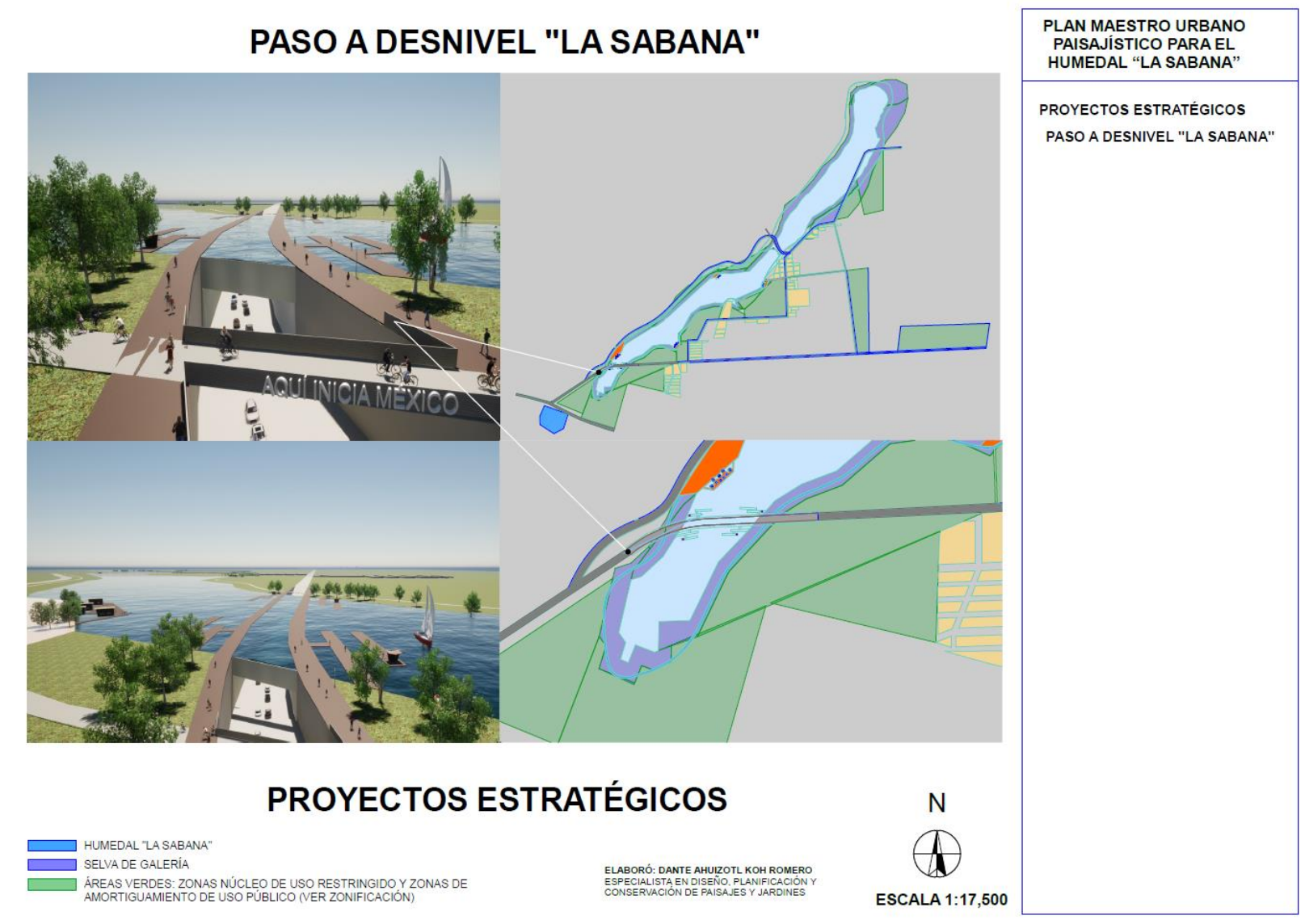

Este proyecto consiste en una vialidad vehicular que pasa por debajo del humedal, dejando un mensaje muy claro: el hombre no está sobre la naturaleza; se complementa con un parque y una señalética que muestra el orgullo de la ciudad: Aquí inicia México. 
Figura 70. Paseo Barrial "La Chetumaleña"

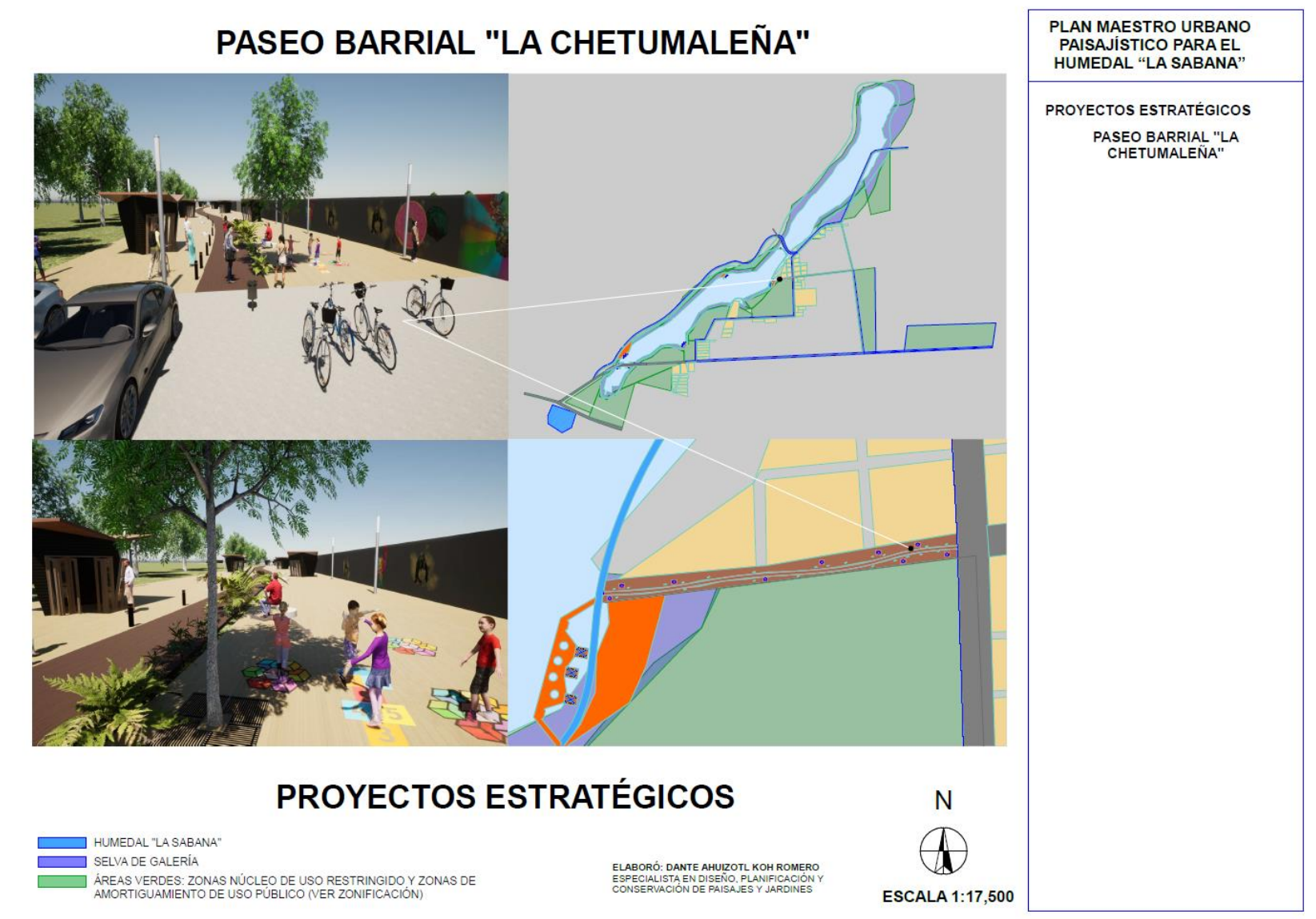

Este parque es un regalo para la ciudad, un paseo para el disfrute de los chetumaleños, niños, padres y abuelos podrán compartir un espacio diseñado para ellos, cuenta con mobiliario urbano, vegetación y con una vista espectacular a "La Sabana". 
Figura 71. Bulevar "La Sabana"

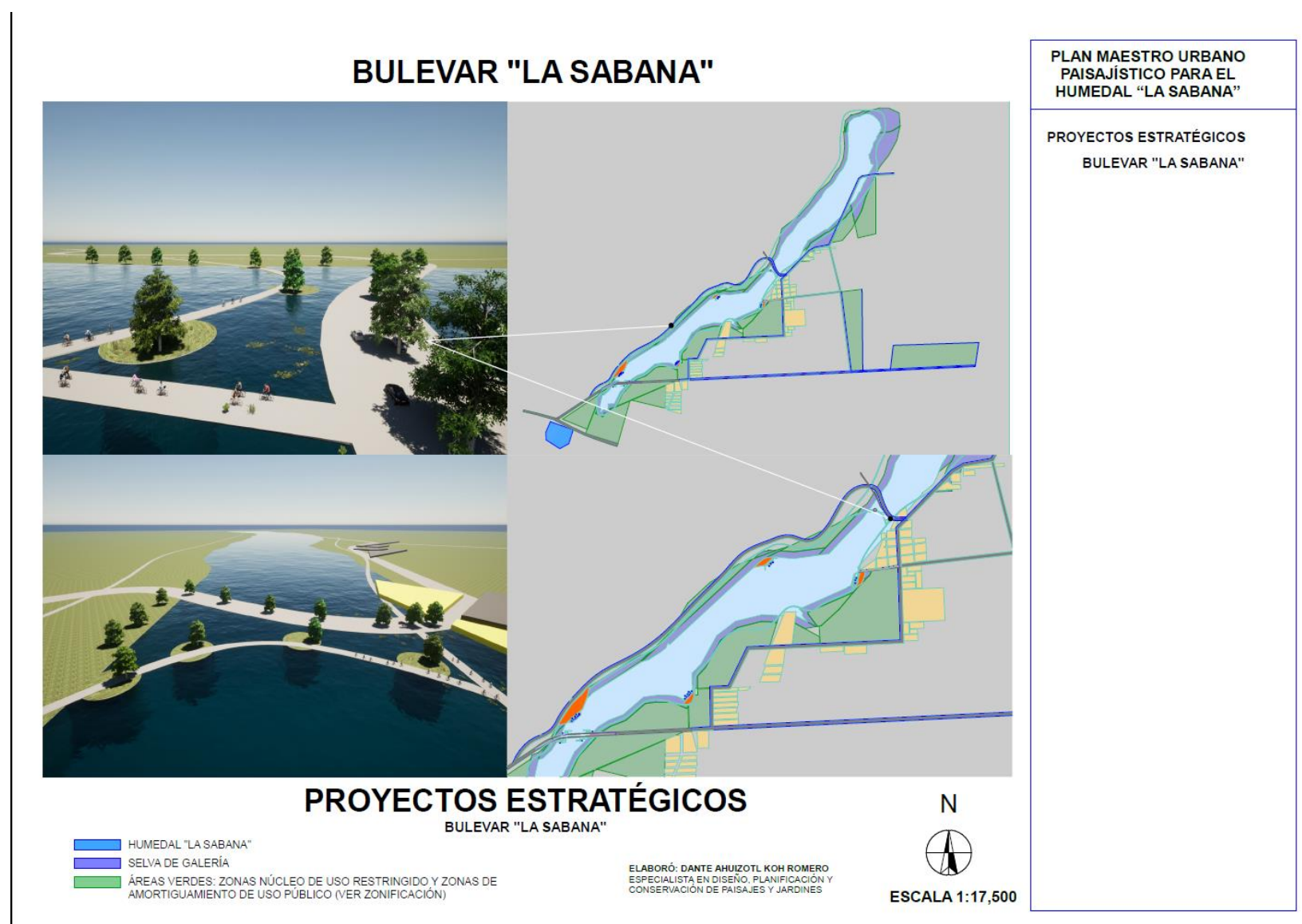

Este bulevar es una vialidad vehicular que facilita la movilidad urbana desde el acceso a la ciudad, resultando en una alternativa complementaria a las avenidas existentes y conectarían la zona norte de Chetumal, a través de un paseo por "La Sabana". 
Figura 72. Circuito ciclista y peatonal "Humedales"

\section{CIRCUITO CICLISTA Y PEATONAL "HUMEDALES"}
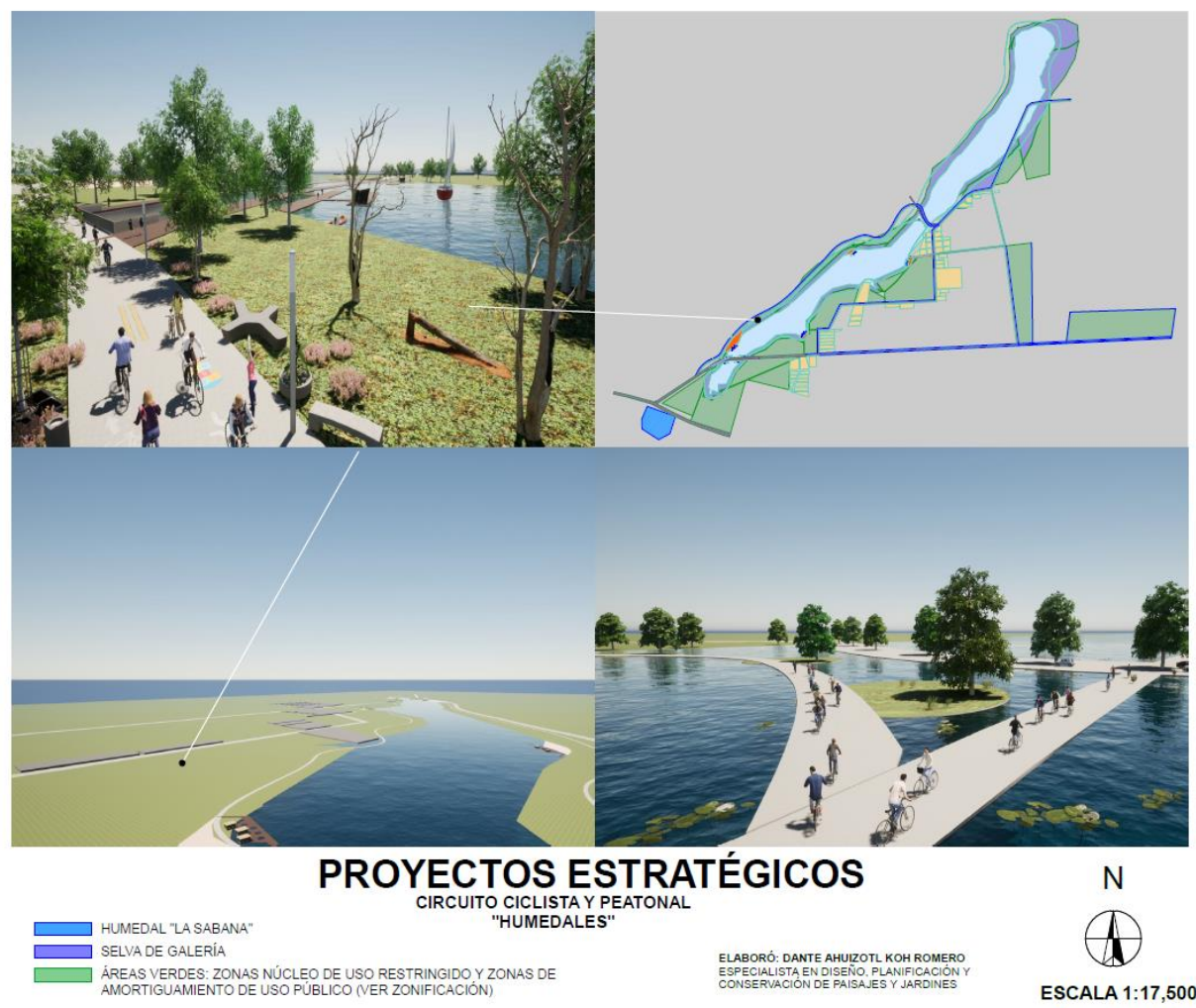

$\mathrm{N}$

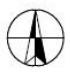

ESCALA 1:17,500

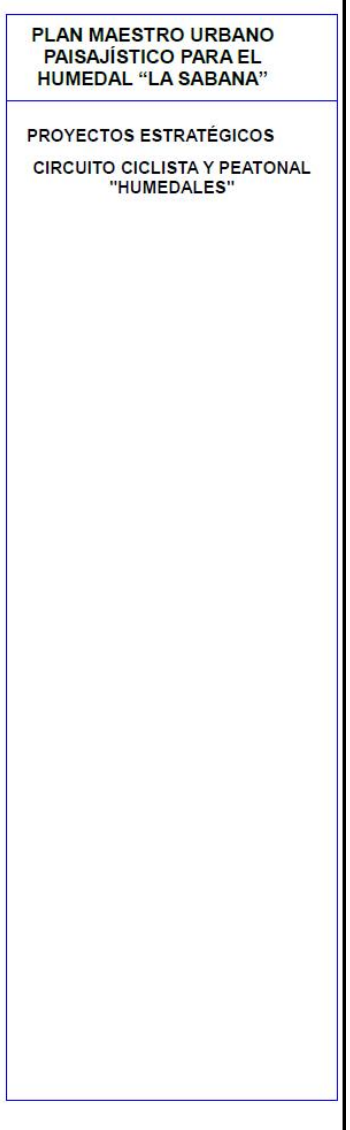

Este circuito permite conectar todos los proyectos estratégicos, generando un paseo a través del cual se va descubriendo el conjunto, diseñado para el paseo recreativo en bicicleta, peatonal y atletismo recreativo. Bordea el humedal permitiendo el disfrute pleno del paisaje. 
Figura 73. Plaza "Dz'onot"

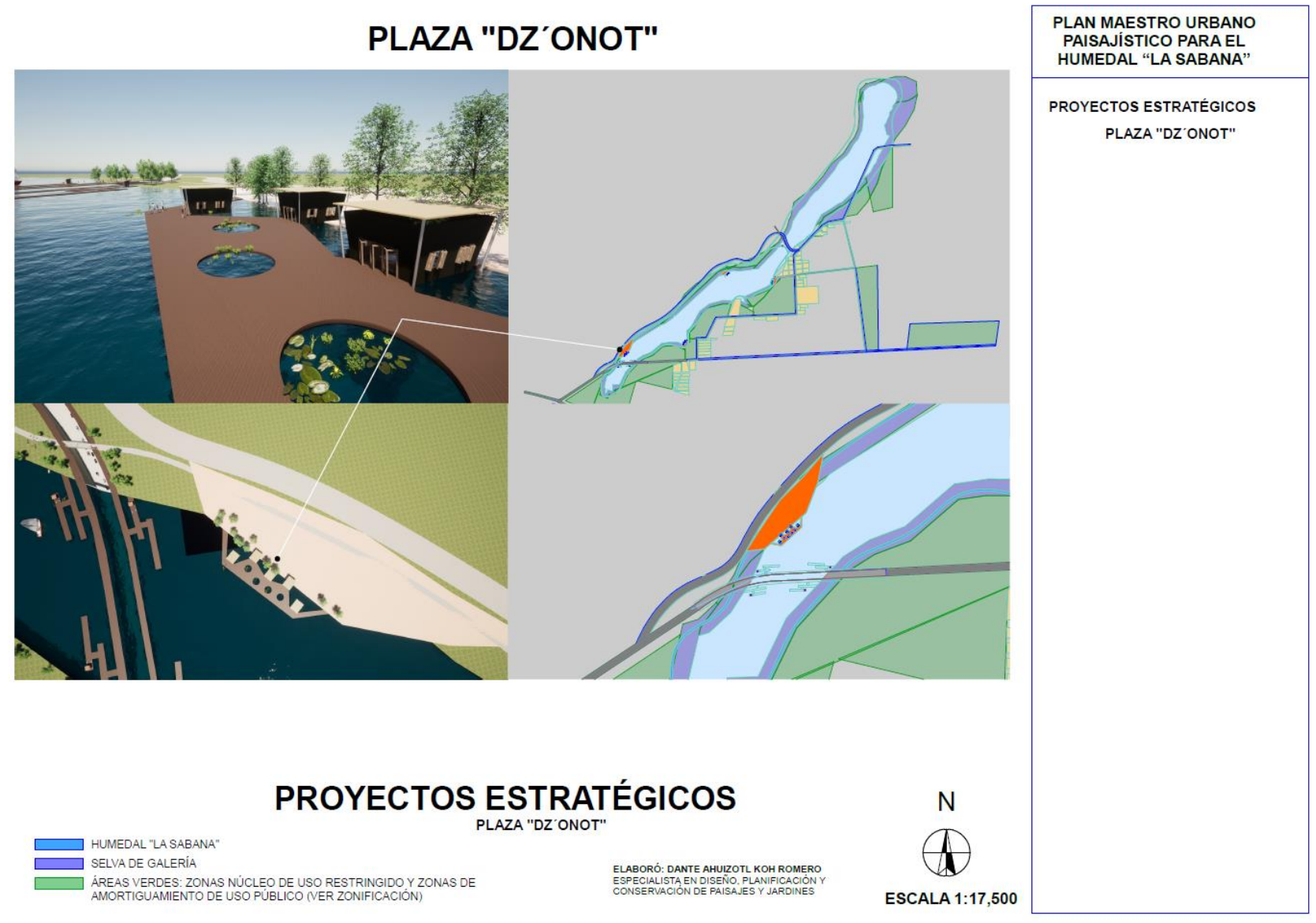

Este espacio está diñado para ser un centro de actividad comercial y recreativa con el disfrute del paisaje; cafeterías, puesto de libros, revistas, artesanías y quiscos, se complementan para atender al paseante, Su nombre significa caverna con agua, en alusión representativa de los cenotes de la zona. 


\section{CONCLUSIONES}

El humedal "La Sabana" es un paisaje cultural que va desde lo degradado hasta lo excepcional. Las principales acciones a tomar van en este sentido; recuperar y minimizar los daños efectuados sobre el humedal, pero también en la infraestructura, la arquitectura, la imagen urbana, y los espacios de encuentro social, esperando fortalecer los lazos sociales pero también el carácter identitario del lugar y con ello poner en valor no solo "La Sabana" sino también la ciudad y las colonias cercanas a ella; por otro lado, las condiciones paisajísticas y ambientales del humedal se deben preservar para que sigan proveyendo de servicios ambientales y culturales, con lo que una de las decisiones más importantes fue designar una franja de protección tipo selva de galería en derredor de "La Sabana", y asignar zona núcleo de protección y de uso restringido, aquellas que se encuentran en buen estado de conservación, que proporcionan esta selva de galería y/o que son zonas inundables. Por su parte, las áreas verdes urbanas que colindan con el humedal se integran en un sistema de parques en una estructura lineal interconectados entre sí y con la ciudad, promoviendo y facilitando la movilidad universal de niños, jóvenes, adultos, adultos mayores, en diferentes modalidades como peatones, ciclistas, atletismo de recreación, en algunos casos proveyendo de circuitos nuevos, y en otros mejorando, ampliando y adecuando las vialidades existentes. Así mismo se propone un parque cultural donde podrán instalarse equipamiento para la educación, la cultura y el recreo, que puede ser un nuevo punto de referencia para toda la Ciudad.

Como se ha venido presentando "La Sabana" forma parte de un sistema complejo cuyos límites van más allá de lo simplemente observable, por este motivo es importante que se gestione tanto la protección de los cuerpos de agua permanentes, como las zonas de escorrentía natural para permitir los flujos del agua hacia el punto final de descarga que es la bahía de Chetumal.

Divulgar y difundir "La Sabana" es una de las actividades que permitirán poner en conocimiento de la gente la importancia ambiental que tiene para la Ciudad, pero por otro lado sugerir en la memoria de la gente su valor cultural, hasta que verdaderamente forme parte de su propia identidad, y con ello contar con la participación ciudadana en su 
cuidado, protección y gestión de su propio paisaje. Por ello seguir divulgando los resultados de esta tesis será parte de los objetivos por seguir.

\section{Recomendaciones}

Abordar el estudio de los humedales requiere reconocer no solo las cualidades físicas sino también el funcionamiento de su propia dinámica hidrológica, y otros conocimientos que se escapan a los alcances de esta tesis, para lo cual se requiere de un equipo de trabajo en las áreas de geografía, biología, edafología, sociología, urbanismo, y los propios de paisajismo y arquitectura; por lo que a falta de ellos tenemos como resultado una breve descripción del humedal en sus características más superficiales. Un estudio más extenso y profundo deberá incluir la participación de las profesiones antes señaladas, y de involucrar a la sociedad en su conjunto, pero particularmente a los habitantes de las colonias adyacentes al humedal; así mismo contar con la participación de las autoridades en todo el proceso, y que en la toma de decisiones queden contempladas todas las aspiraciones y todos los intereses posibles, para llevar a buen término un proyecto de esta magnitud.

La escala propia del proyecto culmina en un Plan Maestro donde se sientan las bases que definen y dan estructura y coherencia a la integración paisajística, urbana y ambiental de "La Sabana"; sin embargo, será necesario desarrollar los proyectos ejecutivos específicos presentados a una escala arquitectónica o de mayor detalle. En este sentido se recomienda abordar "La Sabana" desde varias escalas de análisis: La regional o de la ecología del paisaje, la urbana-paisajística, la paisajística-arquitectónica y finalmente la arquitectónica. Para contemplar el conjunto en el detalle y el detalle del conjunto.

Finalmente se recomienda realizar una labor de difusión y divulgación de los resultados y alcances obtenidos a fin de poner en conocimiento del mayor número de personas y fomentar el interés por el tema, así como hacer llegar los resultados a las autoridades del gobierno a fin de involucrarlos y generar sinergias en relación a la gestión del humedal. 


\section{BIBLIOGRAFÍA Y FUENTES CONSULTADAS}

Batlle, E. (2011). El jardín de la metrópoli. Del paisaje romántico al espacio libre para una ciudad sostenible. Barcelona, España: Gustavo Gili.

Bergkamp, G. y B. Orlando, 1999. Los humedales y el cambio climático: examen de la colaboración entre la Convención sobre los Humedales (Ramsar, Irán, 1971) y la Convención Marco de las Naciones Unidas sobre el Cambio Climático, IUCN. [http://www.ramsar.org/key_unfccc_bkgd_s.htm ] y otros textos

Chueca Goitia, F. (2007). Breve historia del urbanismo (Sexta reimpresión ed.). España: Alianza Editorial, S.A.

Lezama, J. L. (1993). Teoría social, espacio y ciudad. México: El Colegio de México.

Los humedales y la reunión sobre el cambio climático de la COP15 de la Convención Marco de las Naciones Unidas sobre el Cambio Climático (Copenhague, 7 a 18 de diciembre de 2009). Nota informativa del Grupo de Examen Científico y Técnico (GECT) y la Secretaría a las Partes Contratantes

Luz, Rangel (2015). Urbanismo y humedales. Caso de estudio: el humedal "La Sabana", desarrollo urbano en la zona noroeste de Chetumal, México. México: Universidad Veracruzana. Tesis para obtener el grado de Maestra en Arquitectura. Título original: "Aproximación de la mancha urbana de la ciudad de Chetumal con el humedal La Sabana, en 1898"

Periódico Oficial del Estado de Quintana Roo. Tomo I, Número 5 Bis, Sexta Época. Chetumal, Quintana Roo. 15 de marzo de 2005. Decreto por el cual se establece el Programa de Ordenamiento Ecológico Territorial de la Región Laguna de Bacalar, Quintana Roo, México. 
P. Odum, E., \& W. Barrett, G. (2006). Fundamentos de Ecología (5a ed.). México: Thomson Editores, S.A. de C.V.

Programa de Desarrollo Urbano del Área Metropolitana de Chetumal, Calderitas, Xul-Ha (2005). Disponible en línea: < http://seduvi.qroo.gob.mx/index.php/programas-dedesarrollo-urbano-pdu-s/descargas/pdu/06-pdu-area-metropolitana-chetumal-calderitasxulha-31-agos-2005/detail>

"Programa de Desarrollo Urbano de Chetumal, Calderitas, Subteniente López, Huay-Pix y Xul-Ha. Municipio de Othón P. Blanco", publicado el 27 de marzo de 2018 en el periódico oficial del Estado de Quintana Roo

Rosales Miranda, V. et Al (2011). SUSTENTABILIDAD URBANA PLANTEAMIENTOS TEORICOS Y CONCEPTUALES. Quivera. Revista de Estudios Territoriales, 13 (1), 180 196. [Fecha de Consulta 11 de Enero de 2021]. ISSN: 1405-8626. Disponible en: https://www.redalyc.org/articulo.oa?id=401/40118420011

Sato, A. (1977). Ciudad y utopía (Vol. 12). (C. B. hombre, Ed.) Argentina: Centro editor de américa latina.

Secretaría de la Convención de Ramsar (2006). Manual de la Convención de Ramsar: Guía a la Convención sobre los Humedales (Ramsar, Irán, 1971), (4a. ed.). Suiza: Secretaría de la Convención de Ramsar, Gland. [Libro electrónico]. Secretaría de la Convención de Ramsar.

\section{FUENTES DE INTERNET Y PÁGINAS WEB}

Carta mexicana de paisaje [en línea]. Sociedad de Arquitectos Paisajistas de México, 2011 [ref. de 07 de mayo de 2016]. Disponible en web: < https://paisajesculturales.files.wordpress.com/2013/03/cmp_final.pdf>.

Consulta pública del Programa de Ordenamiento Ecológico Local del Municipio de Othón P. Blanco, Quintana Roo. http://www.opb.gob.mx/inicio/wp- 
content/uploads/2015/03/Modelo_Ordenamiento_OPB_10_MARZO_2015\%20Consulta Publica.pdf

Convención sobre la Protección del Patrimonio Mundial Cultural y Natural 1972 [en línea]. París, 16 de noviembre de 1972 [ref. de 09 de Mayo de 2016]. Disponible en web:< http://portal.unesco.org/es/ev.php-

URL_ID=13055\&URL_DO=DO_TOPIC\&URL_SECTION=201.html >.

Directrices Prácticas para la aplicación de la Convención del Patrimonio Mundial [en línea]. París, Enero de 2008 [ref. de 09 de Mayo de 2016]. Disponible en web: < http://whc.unesco.org/archive/opguide08-es.pdf>.

Folleto "El cuidado de los humedales, una respuesta al cambio climático". 2009. Disponible en: https://www.academia.edu/9901278/Humedales_conap_ramsar, fecha de consulta 20 de agosto de 2021.

La Iniciativa Latinoamericana del Paisaje, The Latin American Landscape (LALI) [en línea], 30 de Agosto de 2012 [ref. de 07 de mayo de 2016]. Disponible en web: < http://www.upv.es/contenidos/CAMUNISO/info/U0671043.pdf>.

https://www.ramsar.org/sites/default/files/documents/pdf/lib/lib_manual2006s.pdf

\section{MAPAS Y BASES DE DATOS CONSULTADAS DE INEGI}

INEGI, 2010. Red hidrográfica RH33Ac, Bahía de Chetumal. Escala 1:1000,000 y $1: 150,000$

INEGI, 2010. Documento técnico descriptivo de la red hidrográfica, escala 1:50 000

INEGI, 2010. Conjunto de datos vectoriales de Uso del Suelo y Vegetación. Escala 1:250 000, Serie V (Capa Unión).

INEGI, 2004. carta edafológica del INEGI, y Guía para la interpretación de Cartografía. Edafología. INEGI, 1998. Base de datos geográficos. Diccionario de datos edafológicos escala 1:250,000 (vectorial), 


\section{ANEXOS}

ANEXO 1. Encuesta de valoración de paisajes lacustres del sur de Quintana Roo. Primero, aprecie las fotografías que se exponen a continuación para tener una visión general de los paisajes a valorar. Después, observe detenidamente y valore cada uno de los paisajes representados en una escala del 1 a 5 (de menos a más) en función de su calidad visual. Es decir, califique las fotografías según la belleza escénica del lugar que aparece en la fotografía. Califique muy alto si considera que el paisaje percibido tiene un alto agrado visual o que más le gusta.

Cabe de destacar, que le pedimos que valore los paisajes representados en las imágenes y no la calidad de las fotografías.

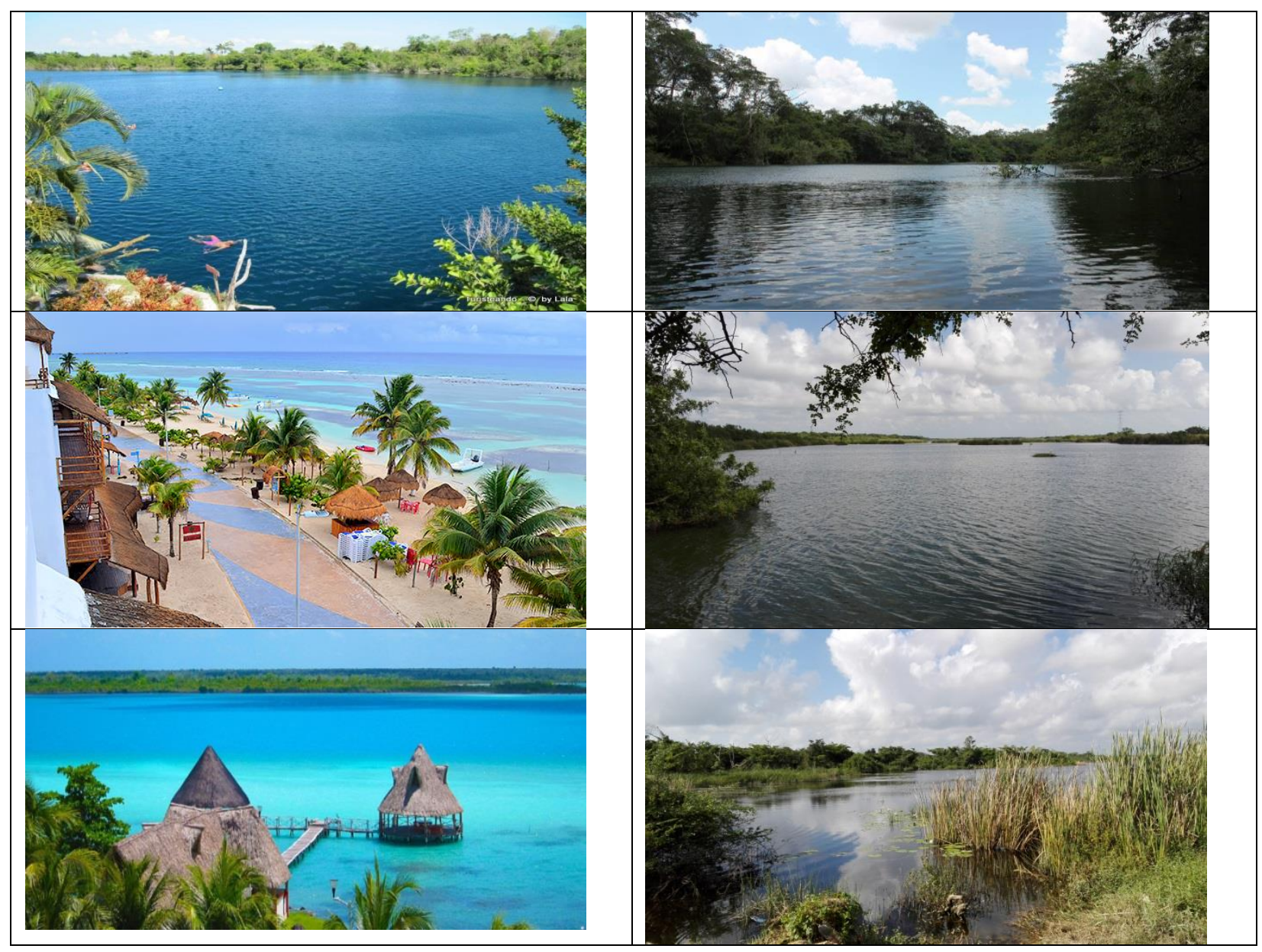



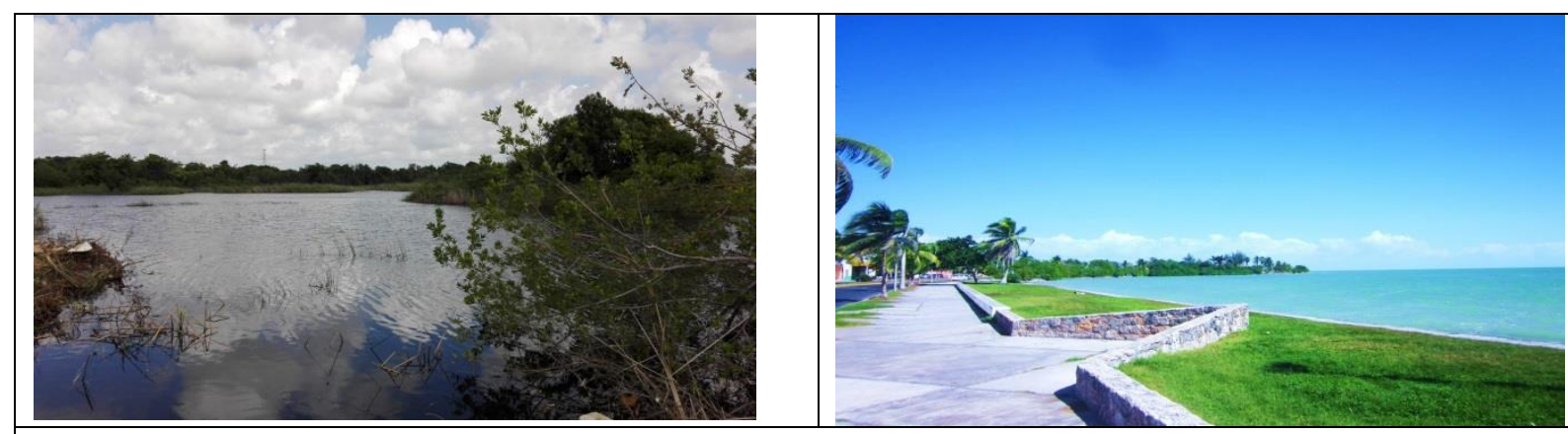

Fuente: Fotografía 1. http://pehaltun.com/bacalar-region/; fotografía 2:

http://sipse.com/novedades/preocupa-aumento-en-el-nivel-del-rio-hondo-37536.html; fotografía 3: www.zonaturistica.com; fotografía 4: propia del autor; fotografía 5: www.jovenesholatur.com; fotografía 6 y 7: propia del autor; fotografía 8: www.panoramio.com

\begin{tabular}{|c|l|l|l|l|}
\hline \multicolumn{5}{|c|}{ REGISTRO DE CALIDAD VISUAL } \\
\hline 1 & 2 & 3 & 4 & 5 \\
\hline Muy baja & Baja & Media & Alta & Muy Alta \\
\hline $\begin{array}{l}\text { Menos } \\
\text { agrado } \\
\text { visual }\end{array}$ & & & & $\begin{array}{l}\text { Más } \\
\text { Agrado } \\
\text { visual }\end{array}$ \\
\hline
\end{tabular}


ANEXO 2. Listado florístico de especies nativas y cultivadas recomendadas para uso ornamental; y especies exóticas no recomendadas para uso ornamental.

El Anexo 4, del Programa de Ordenamiento Ecológico Territorial de la Región de Laguna Bacalar, Quintana Roo, México, señala los siguientes cuadros:

Tabla 7. Especies nativas que pueden ser empleadas en la ornamentación.

\begin{tabular}{|c|c|c|c|}
\hline NOMBRE LOCAL & NOMBRE CIENTÍFICO & FAMILIA & $\begin{array}{l}\text { FORMA DE } \\
\text { VIDA }\end{array}$ \\
\hline Akitz & Thevetia gaumeri & Apocynaceae & Arbusto \\
\hline Akitz amarillo & Thevetia peruviana & Apocynaceae & Arbusto \\
\hline Anacahuite & Cordia sebestena & Boraginaceae & Arbusto \\
\hline Balche & Lonchocarpus punctatus & Fabaceae & Arbusto \\
\hline Boon & Sabal mexicana & Arecaceae & Árbol \\
\hline Ceiba & Ceiba pentandra & Bombacaceae & Árbol \\
\hline Colorín & Erythrina standleyana & Fabaceae & Arbusto \\
\hline Chaka roja & Burcera simaruba & Burseraceae & Árbol \\
\hline Chit & Thrinax radiata & Arecaceae & Árbol \\
\hline Choy & Cochlospermum vitifolium & Cochlospermaceae & Árbol \\
\hline Despeinada & Beaucarnea ameliae & Nolinaceae & Árbol \\
\hline Habin & Piscidia piscipula & Fabaceae & Árbol \\
\hline Huano & Sabal japa & Arecaceae & Árbol \\
\hline Katalox & Swartzia cubensis & Fabaceae & Árbol \\
\hline Kitinche & Caesalpinia gaumeri & Fabaceae & Árbol \\
\hline Kuka & Pseudophoenix sargentti & Arecaceae & Árbol \\
\hline Maculix & Tabebuia rosea & Bignoniaceae & Árbol \\
\hline Nacax & Coccothrinax readii & Arecaceae & Árbol \\
\hline Pich & Enterolobium cyclocarpum & Fabaceae & Árbol \\
\hline Pochote & Ceiba aesculifolia & Bombacaceae & Árbol \\
\hline Ramón & Brosimum alicastrum & Moraceae & Árbol \\
\hline Roble & Erhetia tinifolia & Boraginaceae & Árbol \\
\hline Siricote & Cordia dodecandra & Boraginaceae & Árbol \\
\hline Tasiste & Acoelorhaphe whighii & Arecaceae & Árbol \\
\hline Takinche & Caeslapinia yucatanensis & Fabaceae & Árbol \\
\hline Tsutsuk & Diphysa carthagenesis & Fabaceae & Árbol \\
\hline Tu ha che & Senna atomaria & Fabaceae & Arbusto \\
\hline Tzalam & Lysiloma latisiliqua & Fabaceae & Árbol \\
\hline Uva de mar & Coccoloba uvifera & Polygonaceae & Árbol \\
\hline Xcanlol & Tecoma stans & Bignoniaceae & Arbusto \\
\hline Xiat & Chamaedorea seifrizii & Arecaceae & Arbusto \\
\hline
\end{tabular}


Tabla 8. Especies cultivadas que pueden ser empleadas en la ornamentación

\begin{tabular}{|c|c|c|c|}
\hline NOMBRE LOCAL & NOMBRE CIENTÍFICO & FAMILIA & $\begin{array}{l}\text { FORMA DE } \\
\text { VIDA }\end{array}$ \\
\hline Acalifa & Acalypha wilkesiana & Euphorbiaceae & Arbusto \\
\hline Aralia & Polyscias guilfoylei & Araliaceae & Arbusto \\
\hline Árbol del pulpo & Brassaia actinophylla & Araliaceae & Arbusto \\
\hline Areca & Chrysalidocarpus lutescens & Arecaceae & Arbusto \\
\hline Bambú & Bambusa sp. & Gramineae & Arbusto \\
\hline Bandera & Caladium bicolor & Araceae & Herbácea \\
\hline Belladona & Kalanchoe pinnata & Crassulaceae & Herbácea \\
\hline Clavel de la India & Tabernaemontana coronaria & Apocynaceae & Arbusto \\
\hline Cocinera & Ixora coccinea & Rubiaceae & Arbusto \\
\hline Coco & Cocos nucifera & Araceae & Árbol \\
\hline Cola de gato & Acalypha hispida & Euphorbiaceae & Arbusto \\
\hline Coralillo & Russelia equisetiformis & Scrophulariaceae & Herbácea \\
\hline Croto & Codiaeum variegatum & Euphorbiaceae & Arbusto \\
\hline Difembaqua & Dieffenbachia picta & Araceae & Herbácea \\
\hline Dracena & Dracaena marginata & Liliaceae & Arbusto \\
\hline Espárrago & Aspargus sprengeri & Liliaceae & Herbácea \\
\hline Galán de noche & Cestrum diurnum & Solanaceae & Arbusto \\
\hline Hawaiana & Ixora macrothyrsa & Rubiaceae & Arbusto \\
\hline Lechosa & Pedillanthus tithymaloides & Euphorbiaceae & Herbácea \\
\hline Lengua de suegra & Sanseviera trifasciata & Liliaceae & Herbácea \\
\hline Lirio & Hymenocallis littoralis & Amaryllidaceae & Herbácea \\
\hline Llamarada & Cordolyne terminalis & Liliaceae & Arbusto \\
\hline Mafafa & Xanthosoma roseum & Araceae & Herbácea \\
\hline Maguey morado & Rhoeo discolor & Commelinaceae & Herbácea \\
\hline Naranja agria & Citrus ariantum & Rutaceae & Árbol \\
\hline Novia en barco & Setcreasea purpurea & Commelinaceae & Herbácea \\
\hline Oleander & Nerium oleander & Apocynaceae & Arbusto \\
\hline Palma caribeña & Veitchia merrillii & Arecaceae & Árbol \\
\hline Palma real & Washingtonia filifera & Palmae & Árbol \\
\hline Palmita & Zamia purpurascens & Cycadaceae & Herbácea \\
\hline Platanillo & Canna edulis & Canaceae & Herbácea \\
\hline Teléfono & Scindapsus aureus & Araceae & Trepadora \\
\hline Tulipán & Hibiscus rosa sinensis & Malvaceae & Arbusto \\
\hline Yuca & Yucca elephantipes & Liliaceae & Arbusto \\
\hline
\end{tabular}


Tabla 9. Especies exóticas no recomendadas para su uso en labores de ornamentación.

\begin{tabular}{|l|l|l|l|}
\hline NOMBRE LOCAL & NOMBRE CIENTÍFICO & FAMILIA & FORMA DE VIDA \\
\hline Tulipán africano & $\begin{array}{l}\text { Spathodea } \\
\text { campanulata }\end{array}$ & Bignoniaceae & Árbol \\
\hline Laurel de la India & Ficus benjamina & Moraceae & Árbol \\
\hline Almendro & Terminalia cattapa & Combretaceae & Árbol \\
\hline Pino de mar & $\begin{array}{l}\text { Casuarina } \\
\text { equisetifolia }\end{array}$ & Casuarinaceae & Árbol \\
\hline Framboyan & Delonix regia & Fabaceae & Árbol \\
\hline
\end{tabular}




\section{CURRÍCULUM VITAE DEL AUTOR DE LA TESIS}

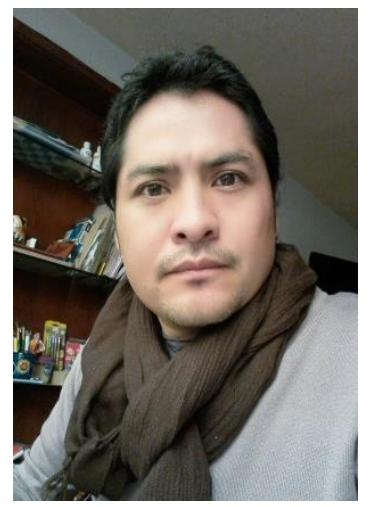

Dante Ahuizotl Koh Romero

ekohlogica@gmail.com

Es Arquitecto por el Instituto Tecnológico de Chetumal en 2002, cuenta con más de 14 años de experiencia en Diseño y Construcción de Inmuebles. En 2005 realiza los estudios de Maestría en Urbanismo, campo del conocimiento Urbano-Regional, en la Universidad Nacional Autónoma de México. Es Especialista en Diseño, Planificación y Conservación de Paisajes y Jardines por la Universidad Autónoma Metropolitana, Unidad Azcapotzalco en 2015, y en ese mismo año ingresa a la Maestría en el mismo campo del conocimiento. A su vez, realiza los estudios de Profesional Técnico en Jardinería en la Escuela de Jardinería de Jardines de México. Cuenta con experiencia impartiendo cursos, talleres, seminarios de titulación y asesorías en tesis de grado, y ha impartido clases durante ocho años en la carrera de arquitectura del Instituto Tecnológico de Chetumal, ha dictado conferencias a nivel Nacional e Internacional en materia de arquitectura, urbanismo y paisaje en diversas sedes nacionales, ha diseñado e impartido talleres en la Universidad Autónoma Metropolitana-Azcapotzalco. Se ha desempeñado en las áreas de: elaboración de Programas de Ordenamiento Territorial en la universidad de Quintana Roo; programas parciales de desarrollo urbano en la ciudad de Cancún, Quintana Roo; diseño arquitectónico de desarrollos ecoturísticos con énfasis en el paisaje; y recientemente en el diseño, estudio y análisis del paisaje. Actualmente es Director del Laboratorio de Paisaje Ekohlógica, emprendimiento dedicado a la divulgación de temas de jardinería y paisaje. 